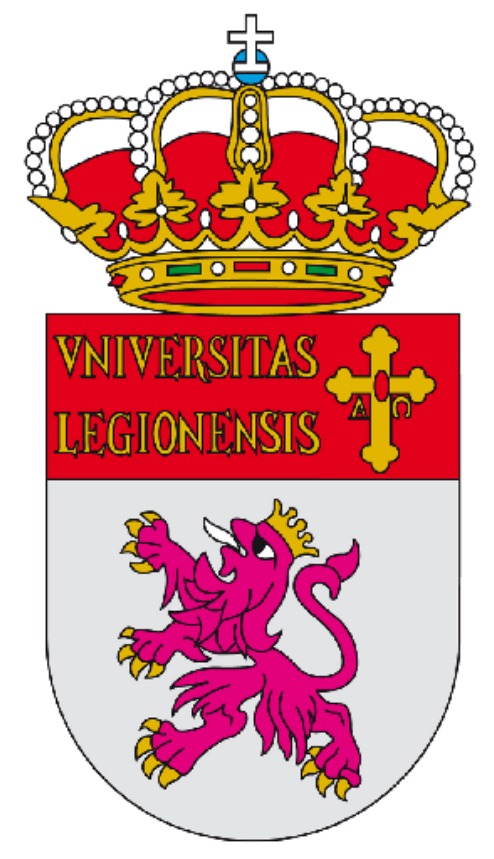

\title{
EL RÉGIMEN JURÍDICO DE LAS ENTIDADES LOCALES MENORES EN CASTILLA Y LEÓN
}

\author{
Tesis Doctoral \\ Virginia Losa Muñiz \\ Directora \\ $D^{\mathrm{a}}$ Mercedes Fuertes López \\ Catedrática de Derecho Administrativo
}

UNIVERSIDAD DE LEÓN

2014 



\section{AGRADECIMIENTOS}

Es para mí muy importante agradecer a todas las personas que me han ayudado en la realización de este trabajo y tendría que comenzar por el principio, dándole las gracias a mi querido profesor Francisco Sosa Wagner, porque él fue la persona que me inculcó primero haciendo la carrera en la Facultad de Derecho de León y también después de la misma, el amor al Derecho Administrativo en general y al mundo local en particular, él fue el que me animó a convertirme en funcionaria de administración local con habilitación de carácter nacional y él fue el que me animó a iniciar la aventura tardía del doctorado.

Muchas gracias a mis padres, a los que les debo lo que soy, como persona y como profesional, ya que me dieron el bagaje de mi educación y el apoyo siempre fiel a todas las decisiones que he tomado en mi vida.

Muchas gracias a Fernando Burón, mi marido, que comparte conmigo la pasión por la profesión de Secretario de Administración Local, siguiendo caminos paralelos en nuestra carrera profesional desde el comienzo juntos hasta este momento, por ser mi apoyo y sustento en mis momentos de miedos e incertidumbres a nivel profesional, porque a nivel personal la gratitud ya es infinita.

Y sobre todo a mi Directora de Tesis, Mercedes Fuertes López, sin la cual este trabajo no habría sido posible, porque gracias a su atención, dedicación, dulzura, profesionalidad y entusiasmo contagioso, he tenido el impulso y estímulo necesarios para poder llegar a puerto. 


\section{ABREVIATURAS UTILIZADAS}

AAPP:

BOCG:

BOCYL:

BOE:

BOP:

CA:

CCAA:

CCLL:

CE:

CORA:

COSITAL:

DA:

DL:

DT:

EA:

EACYL:

EATIM:

EBEP:

EELL:

EHA:

ELM:

EM:

FHE:

FHN:

HAP:

IAE:

IBI:

ICIO:

ICONA:

INE:

IVTM:

JCCA:

JEC:

JEZ:

JJVV:

LM:

LMCYL:

LO:

LOEP:

LOREG:

LORSEGO:
Administraciones públicas

Boletín Oficial de las Cortes Generales

Boletín Oficial de Castilla y León

Boletín Oficial del Estado

Boletín Oficial de la Provincia

Comunidad Autónoma

Comunidades Autónomas

Corporaciones Locales

Constitución Española de 1978

Comisión para la reforma de las Administraciones Públicas

Colegio Oficial de Secretarios, Interventores y Tesoreros de administración local

Disposición Adicional

Decreto Ley

Disposición Transitoria

Estatuto de Autonomía

Estatuto de Autonomía de Castilla y León

Entidad ámbito inferior al municipio

Ley 7/2007, de 7 de mayo, por la que se aprueba el Estatuto Básico del Empleado Público

Entidades Locales

Economía y Hacienda Pública

Entidad local menor

Estatuto Municipal de Calvo Sotelo de 1924

Funcionarios de administración local con habilitación de carácter estatal

Funcionarios de administración local con habilitación de carácter nacional

Hacienda Pública

Impuesto de Actividades Económicas

Impuesto de bienes inmuebles

Impuesto de construcciones, instalaciones y obras

Instituto para la conservación de la naturaleza

Instituto Nacional de Estadística

Impuesto de vehículos de tracción mecánica

Junta Consultiva de Contratación Administrativa

Junta Electoral Central

Junta Electoral de Zona

Juntas Vecinales

Ley 43/2003, de Montes

Ley 3/2009, de Montes de Castilla y León

Ley Orgánica

Ley Orgánica 2/2012, de estabilidad presupuestaria

Ley Orgánica 5/1985, de régimen electoral general

Ley 7/2013, de 27 de septiembre de ordenación, servicios y gobierno del territorio de Castilla y León 
LOTCYL:

LPA:

LRBRL:

LRLCYL:

LRL:

LRJYPAC:

LRSA:

MAP:

MIG:

MINHAP:

OCEX:

PIB:

PTE:

ROF:

RB:

RD:

RM:

RP:

RPDT:

RS:

SAM/SAT:

TC:

$\mathrm{TCu}$ :

TRLCSP:

TRLHL:

TRRL:

TS:

TSJ:

TSJA:

TSJCYL:

UE:
Ley 10/1998, de ordenación del territorio de Castilla y León

Ley 33/2003, de Patrimonio de las Administraciones Públicas

Ley $7 / 1985$, de 2 de abril, reguladora de las bases de régimen local

Ley 1/1998, de 4 de junio de régimen local de Castilla y León

Ley régimen local

Ley 30/1992, de régimen jurídico de las administraciones públicas y procedimiento administrativo común

Ley 27/2013, de 27 de diciembre, de racionalización y sostenibilidad de la administración local

Ministerio de Administraciones Públicas

Mancomunidades de interés general

Ministerio de Hacienda y Administraciones Públicas

Organismo de control externo

Producto Interior Bruto

Participación Tributos del Estado

Real Decreto 2568/1986 por el que se aprueba el reglamento de organización y funcionamiento de las entidades locales

Real Decreto 1372/1986, de 13 de junio, por el que se aprueba el reglamento de bienes de las entidades locales

Real Decreto

Decreto 465/1962, de 22 de febrero por el se aprueba el reglamento de la ley de montes

Real Decreto 1690/1986, de 11 de julio, por el que se aprueba el reglamento de de población y demarcación territorial de las entidades locales

Real Decreto 1690/1986, de 11 de julio, por el que se aprueba el reglamento de población y demarcación territorial de las entidades locales

Decreto de 17 de junio de 1955, por el que se aprueba el reglamento de servicios de las entidades locales

Servicio Asistencia a Municipios

Tribunal constitucional

Tribunal de cuentas

Real Decreto Legislativo 3/2011 por el que se aprueba el Texto Refundido de la Ley de Contratos del Sector Público

Real Decreto Legislativo 2/2004 por el que se aprueba el Texto Refundido de la Ley de Haciendas Locales

Real Decreto Legislativo 781/1986, de 18 de junio por el que se aprueba el Texto Refundido de Régimen Local Tribunal Supremo

Tribunal Superior de Justicia

Tribunal Superior de Justicia de Andalucía

Tribunal Superior de Justicia de Castilla y León

Unión Europea 
INTRODUCCIÓN-1- 9

I. RÉGIMEN JURÍDICO DE LAS ENTIDADES LOCALES MENORES EN CASTILLA Y LEÓN: ANTECEDENTES HISTÓRICOS EN EL PASADO RECIENTE -

1.- PLANTEAMIENTO INICIAL - - 13

2.- EVOLUCIÓN HISTÓRICA DE LA ORGANIZACIÓN DE PUEBLOS Y ALDEAS --16

2.1.- Primeros indicios y época preconstitucional --_-16

2.2.- Periodo constitucional en el Siglo XIX --_-_- 19

2.3.- Periodo constitucional del Siglo XX - - 23

2.3.1.- El Estatuto Municipal de 1924 y las Entidades Locales Menores-------- 23

2.3.2.- Las entidades locales menores en el periodo republicano --------------- 25

2.3.3.- Las entidades locales menores y el autoritarismo ------------------------ 26

2.3.4.- La llegada de la democracia--------- 27

3.- CREACIÓN Y ORGANIZACIÓN ---30

3.1.- Creación de las entidades locales menores - 30

3.2.- Organización, administración y funcionamiento - - 34

3.2.1.- Ley Municipal de 1877---------_---- 34

3.2.2.- Estatuto Municipal de 1924 --_-_-- 34

3.2.3.- Ley Municipal de 1935--_-- 36

3.2.4.- Ley de 1955 -- 37

3.2.5.- Limitaciones a la creación de las entidades locales menores------------ 39

4.- LA EXTINCIÓN DE LAS ENTIDADES LOCALES MENORES -----------39

5.- LOS FINES Y COMPETENCIAS DE LAS ENTIDADES LOCALES

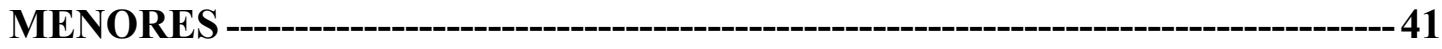

5.1.- Importancia y asignación de los fines de las entidades locales menores --- 41

5.2.- Capacidad y competencia ---_- 42

5.3.- Concurrencia de fines --_- 45

6.- REGULACIÓN DEL RÉGIMEN DE LOS BIENES DE LAS ENTIDADES LOCALES MENORES EN EL DERECHO HISTÓRICO--------_---47

6.1.- Derecho histórico-- 47 
6.2.- Clases de Bienes --------------------------------------------------------------------49

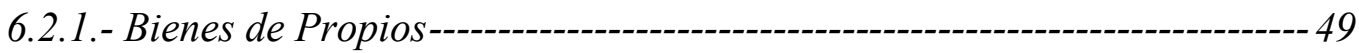

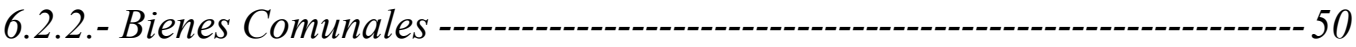

6.3.- Régimen jurídico de los bienes --_-_-- 52

II. REGULACIÓN ACTUAL DE LAS ENTIDADES LOCALES MENORES EN EL

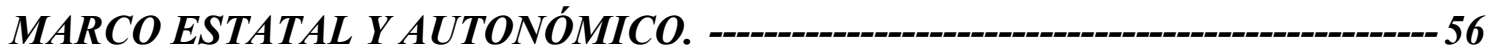

1.- MARCO JURIDICO ESTATAL DE LAS ENTIDADES LOCALES

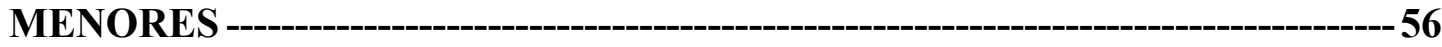

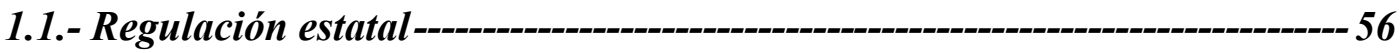

1.2.- El problema de la naturaleza de las entidades locales menores------------- 57

1.3.- La regulación competencial --------------------------------------------------- 59

1.4.- Los límites establecidos para la regulación de las entidades locales menores 61

1.5.- La organización de las entidades locales menores -------------------------- 66

1.6.- El funcionamiento de las entidades locales menores ----------------------- 67

1.7.- La negación de la autonomía a las entidades locales menores------------- 71

2.- EL RÉGIMEN ELECTORAL DE LAS ENTIDADES LOCALES

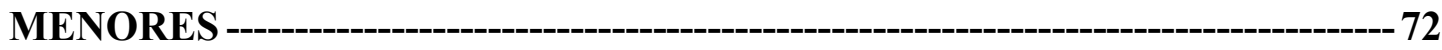

2.1.- La regulación actual del régimen electoral de estas entidades ------------- 72

2.2.- La elección del alcalde pedáneo en la LOREG ------------- 74

2.3.- Constitución de la Junta Vecinal --_-_--- 77

2.4.- Elección en las ELM que funcionan en régimen de Concejo Abierto ----- 79

2.5.- La Moción de Censura en las ELM--_--- 79

2.6.- La constitución de Comisiones Gestoras en las ELM----------------- 81

3.- NATURALEZA Y REGIMEN JURIDICO DE LAS ENTIDADES LOCALES MENORES EN CASTILLA Y LEON ----------------------------------83

3.1.- La estructura municipal en Castilla y León -------------------------------- 83

3.2.- La regulación autonómica en Castilla y León de las ELM ------------- 87

3.2.1.- Antecedentes en la legislación autonómica de Castilla y León ----------- 87

3.2.2.- Régimen jurídico actual -------------------------------------------------------- 89

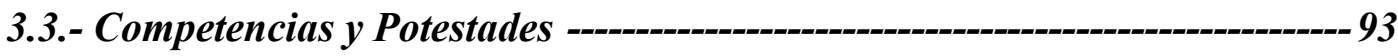

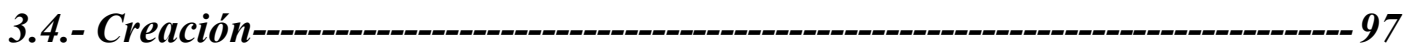

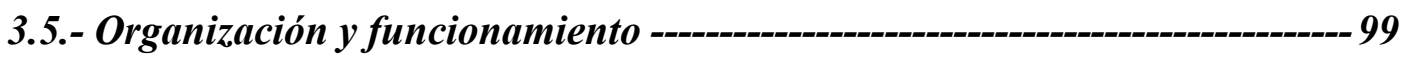


3.6.- Recursos económicos 103

3.7.- Modificación y supresión 105

4.- LA LEY 7/2013, DE 27 DE SEPTIEMBRE DE ORDENACION, SERVICIOS Y GOBIERNO DEL TERRITORIO DE CASTILLA Y LEÓN Y SU APLICACIÓN A LAS ENTIDADES LOCALES MENORES -------------- 108

4.1.- Planteamiento de la reforma ---------------------------------------- 108

4.2.- Aplicación al régimen jurídico de las entidades locales menores---------- 111

5.- LA LEY 27/2013, DE RACIONALIZACIÓN Y SOSTENIBILIDAD DE LA

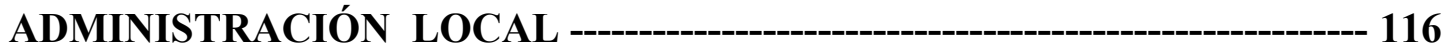

5.1.- Contexto y antecedentes de la reforma ---------------------------- 116

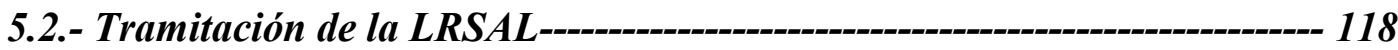

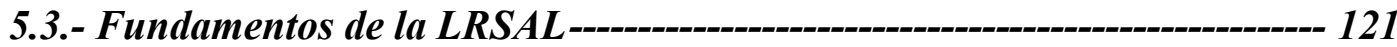

5.4.- Afectación de la LRSAL al régimen jurídico de las entidades locales

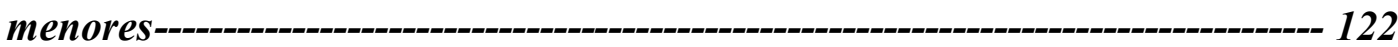

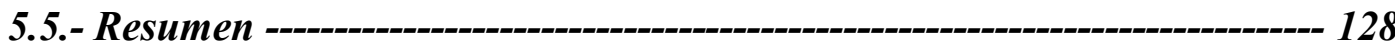

III. LA PROBLEMÁtiCA CON EL DESEMPEÑO DE LAS FUNCIONES DE SECRETARÍA 136

1.- LA REGULACIÓN DE LAS FUNCIONES DE SECRETARIA EN LAS ENTIDADES LOCALES MENORES 136

2.- DESEMPEÑO DE FUNCIONES DE SECRETARÍA Y SU PROBLEMÁTICA 141

3.- OTRAS REGULACIONES ALTERNATIVAS Y SUPUESTOS EN OTRAS COMUNIDADES AUTÓNOMAS 145

4.- EL EFÍMERO DECRETO 33/2013, DE 18 DE JULIO POR EL QUE SE ESTABLECEN LOS TÉRMINOS PARA EL DESEMPEÑO DE LAS FUNCIONES PÚBLICAS NECESARIAS Y RESERVADAS A LOS FUNCIONARIOS CON HABILITACIÓN DE CARÁCTER ESTATAL EN LAS ENTIDADES LOCALES MENORES DE CASTILLA Y LEÓN -------- 148

5.- LA SITUACIÓN GENERADA POR LA LRSAL 27/2013 ------------------ 156

6.- CONSIDERACIONES --159 
IV. PROBLEMÁtICA EN LA UTILIZACION DE LOS BIENES DE LAS

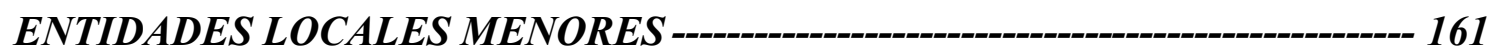

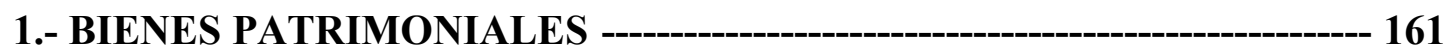

1.1 Régimen jurídico ----------------------------------------------------------------- 161

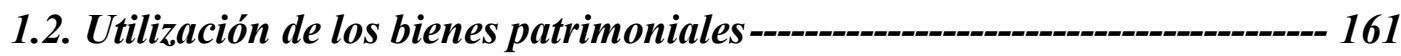

2.- BIENES COMUNALES--------------------------------------------------------------- 165

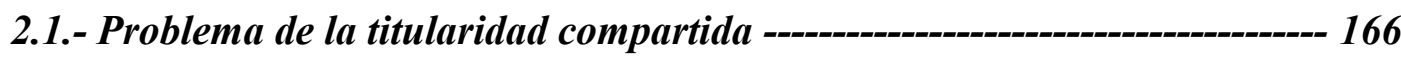

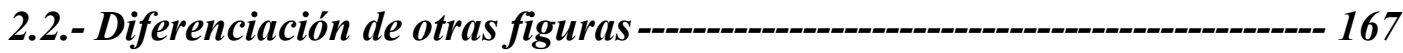

2.3.- Regulación de los aprovechamientos comunales mediante ordenanzas

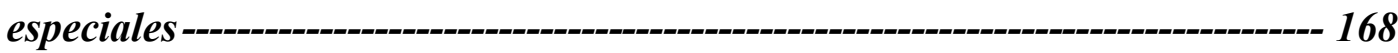

2.4.- Beneficiarios de los aprovechamientos y el problema de las condiciones de

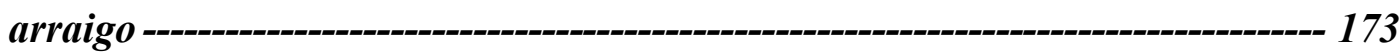

2.5.- Utilización de los bienes comunales------------------- 177

2.5.1.- La explotación colectiva o comunal como modalidad de

aprovechamiento preferente y general ---------------------------------------------- 178

2.5.2.- Modalidades de aprovechamiento en caso de que el disfrute común fuere impracticable

179

2.6.- Supuestos de alteración de la calificación jurídica de los bienes comunales 183

2.7.- Confluencia de bienes comunales con otro tipo de aprovechamientos --- 184

3.- LOS MONTES 185

3.1 Las competencias locales en materia forestal ----_-- 185

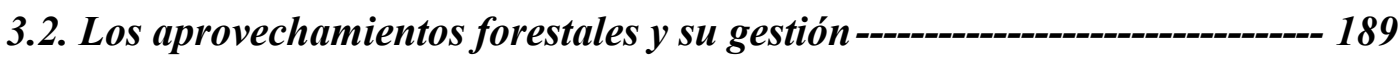

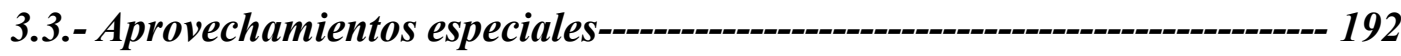

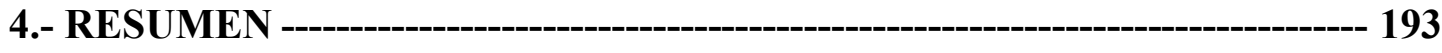

V. EL PROBLEMA DE LA RENDICIÓN DE CUENTAS DE LAS ENTIDADES LOCALES MENORES O LA AMENAZA FANTASMA DE SU DESAPARICIÓN.

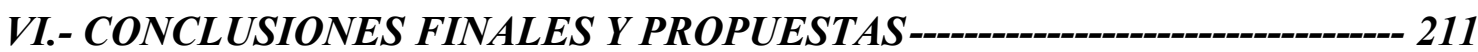

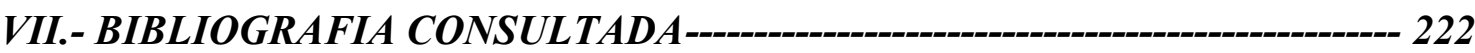

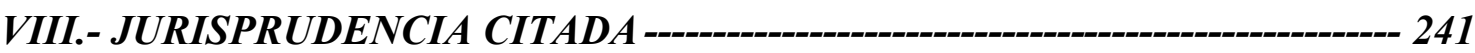


"Recorramos una vez más la geografía de nuestras aldeas y comprobemos como el secreto de la aldea se sigue abriendo en la gran rosa-cuantas veces encendida-de su asamblea de vecinos, y que en aquella calma cósmica que rodea el lugar y que levemente perfuma la brisa de la sierra o del río brotan, más o menos desbrozadas, pero brotan siempre, las fuentes primarias de la vida, de la vida familiar, de la vida social, del enorme y hasta pavoroso complejo institucional de nuestros días".

\section{Florentino Agustín Díez González.}




\section{INTRODUCCIÓN}

La presente tesis doctoral pretende contribuir a dar a conocer una de las representaciones jurídicas más habituales dentro de la administración local y a la par más desconocidas. Causa sorpresa comprobar el escaso número de personas que, cuando se habla de problemas de la vida local española, saben o tienen una noción de lo que es una Entidad Local Menor y más concretamente, que sepan la función que la misma desempeña o debiera desempeñar en la Administración local española.

Partiendo del origen y reconocimiento en el ordenamiento jurídico de estas entidades, analizaré la motivación y propia existencia de las mismas hasta llegar a la regulación actual. A lo largo de la evolución cronológica que se expondrá un hecho parece innegable, y es que las entidades locales menores, por su origen natural y espontáneo, han de considerarse necesariamente anteriores a cualquier regulación legal de la vida local, adquiriendo por este motivo un rango y relieve singular.

Los cambios normativos operados en el año 2013, tanto a nivel estatal como autonómico, permiten reflexionar en aspectos más profundos que aquellos que el legislador ha hecho o ha dejado de hacer. La realidad actual es que la figura de la Entidad Local Menor, en general, no responde al fundamento científico de su existencia, ni actúa como organismo complementario y colaborador del municipio del que depende, constituyendo en algunos casos un lastre torpe, que reduce la acción del municipio en el concreto territorio de la entidad y en no pocas situaciones en un continuo foco de conflictos entre ambas entidades. La pasividad del legislador y de las administraciones que tienen atribuidas las competencias de control de legalidad de todas las Administraciones Públicas, incluidas las ELM, ha provocado que se haya llegado a una situación de, casi podríamos decir, anarquía, no solo en la gestión misma de su patrimonio, donde cada una de estas entidades lo hace a su manera y soslayando continuamente lo establecido en la normativa aplicable, sino que prácticamente viven al margen del ordenamiento jurídico y apenas se han tomado medidas al respecto. 
El contexto de crisis económica e institucional ha provocado el replanteamiento de una reforma profunda de la Administración Pública, eligiendo, en lo que respecta a estas entidades, el no abordar, como veremos, la regulación tanto tiempo esperada de las mismas, sino optar casi por una total desactivación de ellas. Así las cosas las reformas normativas que veremos, han puesto el foco sobre estas entidades, pero de una manera parcial, casi por buscar algún culpable y justificar la reducción del gasto en la presunta supresión de estas entidades, si bien y en alguna ocasión se ha observado que las mismas están inertes, gestándose una de las preguntas que se plantean en el estudio de esta tesis, ¿deben subsistir las Entidades Locales Menores?.

Se justificará la existencia de aquellas que de una manera racional, madura y eficaz puedan garantizar el adaptarse a los tiempos que vivimos y a las exigencias del ordenamiento jurídico tan cambiante y cada vez más exigente, pero con una profunda modificación del régimen jurídico de las mismas, que de un papel más preponderante al municipio.

Asimismo, y puesto que inciden en mi opinión, como núcleo justificativo para su propia existencia, analizaré los tres problemas prácticos más frecuentes en la gestión de la vida administrativa de estas entidades y que por su propia trascendencia han sido seleccionados:

- la conflictiva gestión patrimonial de los bienes de titularidad de las entidades locales menores, en concreto, la explotación y uso de los de naturaleza comunal y su solapamiento con la naturaleza y uso de los montes de utilidad pública;

- la polémica sobre quién es la persona indicada por el ordenamiento para el correcto desempeño del puesto de secretaría en estas entidades, dado que se trata de funciones reservadas en principio para unos determinados funcionarios como son los funcionarios de habilitación de carácter nacional, así como la escasa o casi nula regulación de este tema en las normas de los últimos veinte años, y la imprecisión ante la llevanza de estos puestos por otras personas; 
- el problema del cumplimiento en la rendición de cuentas de estas entidades locales a los órganos de fiscalización externa y otras administraciones, problema íntimamente relacionado con el anterior, y que puede llegar a afectar a su propia pervivencia.

Como limitaciones de la investigación podemos citar además de los fundamentos teóricos y su relevancia práctica más que científica en la aplicación del día a día en la vida de estos entes, y las razones de selección de los estudios de caso, los siguientes:

1.- La primera limitación posible está relacionada con un dilema inevitable que ha sido ampliamente reflexionado en metodología comparada: la opción de uno o varios casos. Al optar por estudiar los tres problemas más frecuentes en la gestión de estos entes esperamos ganar en profundidad y metodología práctica.

2.- La segunda limitación tiene que ver con la dificultad en la obtención de información más amplia, pues es un tema escasamente tratado, sobre todo en el caso de la rendición de cuentas y análisis de las funciones contables y de intervención de estas entidades pero con una repercusión muy importante.

En cuanto a la metodología empleada, el plan de actuación de la presente tesis ha seguido diferentes etapas, que podemos ir estableciendo:

- De investigación bibliográfica a partir de las fuentes disponibles referidas en el apartado correspondiente a la Bibliografía.

- Determinar los supuestos problemáticos a analizar.

- La formulación de los supuestos, decidiendo qué tipo de información y análisis va a ser relevante en nuestra investigación.

- Realización del trabajo más de campo con los datos obtenidos de las fuentes de trabajo: Diputación Provincial, Junta de Castilla y León, datos y colaboración con el Consejo de Cuentas de Castilla y León, jurisprudencia etc.... Recopilación y análisis documental, estudios de datos estadísticos, comparativa de actuaciones con otras administraciones similares etc....

- Redacción y análisis de las conclusiones y aportaciones del trabajo. 
La presente tesis doctoral se divide en cuatro partes fundamentales: origen y evolución del régimen jurídico de las ELM en el pasado reciente, es decir, el contexto histórico más inmediato y su regulación normativa; análisis comparativo de la regulación normativa entre todas las Comunidades Autónomas del país; marco teórico actual con especial referencia a las últimas reformas legislativas que inciden de una manera incisiva en el tema y por último el análisis y propuesta de solución de los tres problemas seleccionados como más frecuentes y demandados, siendo por último la parte correspondiente a las conclusiones del trabajo presentado. 


\section{RÉGIMEN JURÍDICO DE LAS ENTIDADES LOCALES MENORES EN CASTILla Y LEÓN: ANTECEDENTES históricos EN EL PASAdo RECIENTE}

\section{1.- PLANTEAMIENTO INICIAL}

Las Entidades Locales Menores (en adelante ELM) conforman una modalidad de entes sobre los que se suele tener un total y absoluto desconocimiento, si bien en la Comunidad Autónoma de Castilla y León tienen un amplísimo predicamento, sobre todo, como veremos, en las provincias de Burgos, León y Palencia. GARRIDO FALLA dice que el territorio de las mismas es a la vez de naturaleza estatal al "jugar un papel fundamental en la división territorial del Estado" ${ }^{1}$. Más bien diríamos que son a la vez municipales, el territorio se superpone, en una y otra entidad, como elemento definitivo, de ahí que la Ley de Bases de Régimen Local 7/1985, de 2 de abril (en adelante LRBRL) no las incluyera dentro de las Entidades territoriales².

Estas entidades aparecían como dotadas de personalidad jurídica, titulares de unos bienes y para la administración descentralizada de unos servicios e intereses particulares y diferenciados de un núcleo de población que se encuentra separado del núcleo principal del municipio del cual forma parte ${ }^{3}$.

¿Por qué esa superposición? TORRES CURDI ${ }^{4}$ cree que se justifica en la existencia de núcleos de población separados y la necesidad de dotarles de una

\footnotetext{
${ }^{1}$ GARRIDO FALLA, F. "Entidades Locales Menores", Revista de estudios de administración local y autonómica. $n^{\circ} 35$. 1947. Pág. 688.

${ }^{2}$ Vid. Artículo 3 LBRL. Aunque desde el punto de vista terminológico existe una contradicción, ya que la LBRL se refiere a éstas como "entidades de ámbito territorial inferior al municipio".

${ }^{3}$ Como afirma RIVERO YSERN, JL. se trata de un fenómeno de descentralización municipal que supone la transferencia de competencias del municipio a la entidad local inframunicipal. Esta descentralización podrá ser más o menos intensa pero nunca significará la total independencia de la entidad local inframunicipal del municipio en el cual se integra. Vid. "Manual de Derecho Local" Madrid. Civitas. 2003, pág. 213.

${ }^{4}$ TORRES CURDÍ, F. “Las Entidades Locales Menores en el derecho administrativo español”, Madrid. IEAL. 1985. Pág. 32.
} 
funcionalidad sustitutoria respecto del municipio, pero el problema va más allá y se agudiza como veremos, en aquellos términos municipales donde en la propia capitalidad del municipio existe también una ELM. ¿Función sustitutoria o duplicidad administrativa y burocrática? Con su existencia se les otorga la posibilidad de intervenir por sí mismas en relaciones y situaciones jurídicas que de modo directo les van a ser imputables, y de poder autogestionar sus intereses de forma diferenciada a la gestión centralizada del municipio matriz. De esta forma municipio y entidad vienen a constituirse en administraciones distintas, lo que no ocurriría si esta última supusiera la creación de un mero órgano "desconcentrado" del municipio con la organización, funciones y competencias que el Ayuntamiento les confiriera.

Señala TORRES CURDI que las ELM y los municipios son entidades autárquicas, pero que las ELM se encuentran limitadas por dos entes: el estado y el municipio $^{5}$. Entiendo que la autonomía que se predica de los municipios españoles no es autarquía, sino que forma parte de un ordenamiento derivado, y no puede oponerse al concepto de unidad, sino que es dentro del mismo donde alcanza su verdadero significado, así lo propugna nuestra Carta Magna como veremos más adelante. Además dicha autonomía, y siguiendo a SOSA WAGNER, es de carácter bifronte, al relacionarse con dos ordenamientos superiores, tal y como son el estatal y el autonómico, ya que serán ambos legisladores los llamados a dotar de contenido dicha autonomía y concretar el interés local ${ }^{6}$.

Para afrontar históricamente la existencia de estas entidades no quiero dejar de referirme inicialmente a la previsión recogida en la Carta Europea de Autonomía Local, (aprobada por Instrumento en el año 1988), la cual reconoce a las ELM, tal y como prosigue: "El Reino de España declara que la Carta Europea de la Autonomía Local se aplicará en todo el territorio del Estado en relación con las colectividades contempladas en la legislación española de régimen local y previstas en los artículos 140 y 141 de la Constitución. No obstante, el Reino de España únicamente no se considera vinculado por el apartado 2 del artículo 3 de la Carta en la medida en que el

\footnotetext{
${ }^{5}$ TORRES CURDI, F. op. cit. pág. 35.
}

${ }^{6}$ SOSA WAGNER, F. “Manual de Derecho Local”. Aranzadi. 2001. Pág. 50. 
sistema de elección directa en ella previsto haya de ser puesto en práctica en la totalidad de las colectividades locales incluidas en el ámbito de aplicación de la misma ${ }^{7}$ ". Por tanto y de acuerdo con el reparto competencial que establece nuestra Constitución de 1978 en su artículo 149.1.18 CE, es que la regulación de las entidades de ámbito territorial inferior al municipio corresponde a las CCAA, y que éstas podrán utilizar para referirse a ellas la denominación tradicionalmente existente en cada Comunidad o cualquier otra que establezca la normativa autonómica. Como veremos, en la legislación española de régimen local estas entidades se han conocido comúnmente bajo el nombre de entidades locales menores, y que muchas leyes autonómicas han optado por esta denominación (así es en la Ley 1/1998, de 4 de junio de Régimen Local de Castilla y León).

Así las cosas, la previsión normativa de la existencia de estas entidades posibilita la existencia de una administración descentralizada de las concentraciones de población, siempre (ya veremos más adelante que a veces no se cumple) que en ese núcleo no tenga su sede el Ayuntamiento ${ }^{8}$.

\footnotetext{
7 Artículo 13 de la Carta se titula de Entidades a las cuales se aplica la misma, y dice: Los principios de autonomía local contenidos en la presente Carta se aplican a todas las categorías de Entidades locales existentes en el territorio de la parte contratante. Sin embargo, cada parte contratante puede, en el momento de depositar los Instrumentos de Ratificación, Aceptación o Aprobación de la presente Carta, designar las categorías de Entidades locales y regionales a las que quiere limitar el campo de aplicación o que quiere excluir del campo de aplicación de la presente Carta. Puede igualmente incluir otras categorías de Entidades locales o regionales en el campo de aplicación de la Carta por vía de comunicación posterior escrita al Secretario General del Consejo de Europa.
}

${ }^{8}$ PALLARES SERRANO, A. "Aproximación al régimen de las entidades de ámbito territorial inferior al municipio de Cataluña". Revista de Estudios de la Administración Local y Autonómica, $n^{\circ}$ 309. 2009, pág. 136, destaca en su artículo una serie de características aplicables a dichas entidades, y que recojo aquí por lo interesante de la exposición:

“- Se trata de concentraciones de población, es decir, de núcleos habitados. Por lo tanto, sin residentes no puede haber entidad municipal descentralizada.

- La concentración de población se ha de ubicar dentro de un municipio. Es decir, una entidad municipal descentralizada no puede tener un territorio que pertenezca a más de un municipio.

- La concentración de población ha de estar separada del núcleo principal. La normativa no nos indica una distancia mínima entre un núcleo y el otro.

- La capitalidad del municipio no se puede constituir en entidad municipal descentralizada" 


\section{2.- EVOLUCIÓN HISTÓRICA DE LA ORGANIZACIÓN DE PUEBLOS Y}

\section{ALDEAS}

\section{1.- Primeros indicios y época preconstitucional}

Históricamente el nacimiento de las entidades locales menores va unido a la defensa de los intereses económicos de los pueblos ${ }^{9}$. Los primeros indicios de población agrupada los encontramos a lo largo de los S. X al S. XIII ${ }^{10}$, cuando los primitivos núcleos de población se asentaban alrededor de una iglesia o de una propiedad, recibiendo diferentes nombres tales como: aldeas, pueblos, lugares, parroquias, caseríos, etc.... El origen de los mismos está vinculado con la figura de la "aldea11", es decir, proceden de un mundo eminentemente rural $^{12}$. Se muestra una unidad agraria con aspiraciones de autarquía.

\footnotetext{
${ }^{9}$ Según TORRES CURDI la existencia de la entidad local menor, cualquiera que sea su denominación, constituye un fenómeno que bien pude calificarse de universal. Como figuras análogas cita la aldeia o el povo de Portugal, la parroquia civil en Inglaterra, la borgata o frazioni en Italia, la section de Communes en Francia y la parroquia en Suiza. Vid "Las entidades locales menores en el Derecho Administrativo español” Instituto de Estudios de Administración Local, Madrid, 1985, pág. 78. En el mismo sentido vid. DIEZ GONZALEZ, FA. "La comunidad de aldea, especial referencia a León” 1955. Pág. 187, y GARRIDO FALLA, F. op cit pág. 689.

${ }^{10}$ MARTINEZ MANOVEL, C./PEDREIRA GARCIA, J. "Las entidades locales menores: pasado, presente y futuro", El Consultor de los Ayuntamientos y Juzgados, $n^{\circ} 21$. 2002, pág. 3498, señalan que: El origen de los Concejos se remonta al S. X, a poco de iniciarse la repoblación al norte del Cuero al reunirse los vecinos de un mismo núcleo de población en una asamblea denominada "consilium" y posteriormente concejo, guiados por el Derecho Consuetudinario y los fueros medievales concedidos por los reyes de León y que parecen tener una cierta relación con los antiguos "conventus publicus vecinorum" de época visigoda.

${ }^{11}$ SOSA WAGNER, F. op. cit. pág 24: La célula básica de la convivencia social en esta época medieval es la villa, aldea o ciudad, que se instala en la que sobrevive de los espacios ocupados por la población romana o la romana visigoda, o se crea "ex novo" como núcleo defensivo. Adquieren pronto el significado de agrupación urbana, y tienen, según los casos, bien un objetivo político social, de fijación de la población, o bien religioso, como es el caso de las que pertenecen al Camino de Santiago [...] o son villas marineras $[\ldots]$ o persiguen la explotación de un área rural o aseguran una vía de comunicación.

12 DIEZ GONZALEZ, F.A."La Comunidad de aldeas, especial referencia a León". 1955. Pág. 185: "España es un semillero de aldeas, y es la aldea, aunque su nombre genérico varíe según las regiones, la que principalmente define y acusa la ruralidad peninsular y la esencial condición de pueblo agrícola que tiene el español".
} 
Siguiendo a PIZARRO NEVADO ${ }^{13}$, en una primera etapa aparecieron comunidades concejiles, dispersas geográficamente pero unidas por un vínculo de dependencia de un señor eclesiástico o laico, dando lugar al llamado orden concejil. El señor podía ser incluso un municipio (señorío concejil) ${ }^{14}$. Estos órdenes se producen a partir del S.XI, plasmándose ese orden concejil en unos fueros donde se reconoce una cierta personalidad jurídica propia frente a otras autoridades señoriales, así como una serie de derechos y privilegios. Durante ese tiempo orden concejil y orden señorial coexisten, si bien a partir del S. XII se advierte un proceso de unificación de poder en manos del monarca, mediante el envío de funcionarios y la creación de organismos comunes, como las merindades o los adelantamientos mayores y menores ${ }^{15}$. Pero la figura capital en la Corona de Castilla, a partir del S. XIV, fue la del Corregidor ${ }^{16}$.

Posteriormente la llegada de la dinastía borbónica a la monarquía española supuso la imposición de un mayor centralismo, de difícil coexistencia con la realidad diversa local. Dice PIZARRO NEVADO ${ }^{17}$ que con anterioridad a la Constitución de Cádiz, la situación en los asentamientos rurales es la de la existencia de las aldeas dependientes de la jurisdicción de una villa o la de arrabal de las ciudades. A los ${ }^{13}$ PIZARRO NEVADO, R. "Las entidades de ámbito inferior al municipio", Centro de Estudios
municipales y de cooperación interprovincial, 2002, pág. 27.

${ }^{14}$ SOSA WAGNER, F. op cit., Pág. 24: El marco jurídico político era, sin embargo, el señorío y el municipio. El señorío es consecuencia de la extinción de la organización de la España visigoda y de la dispersión de la población que, en una época donde las relaciones sociales están dominadas por la violencia, y donde se empieza a hacer patente la diferencia entre fuertes y débiles, éstos se ven obligados a ponerse al amparo de aquéllos, naciendo así el señorío ejercido sobre un vasto espacio físico donde conviven asentamientos de población unidos por el vínculo de dependencia con un señor que goza de inmunidad y, con ella, de facultades de típicas del poder real. [...]. El señorío, inicialmente solariego pasa así a ser jurisdiccional y puede ser eclesiástico o laico. El laico se diferencia según que su titular sea un señor, titulado o no, o un municipio (los señoríos concejiles). Esta distinción es básica pues nacida durante la Alta Edad Media, subsiste en sus líneas generales hasta las Cortes de Cádiz.

${ }^{15}$ SOSA WAGNER, F. op. cit, pág. 26: Son los adelantados y los merinos castellano-leoneses y sobre ellos el merino mayor o los veguers catalanes, que mandan en sus circunscripciones territoriales llamadas merindades y veguerías.

${ }^{16}$ SOSA WAGNER, F. op. cit. pág. 27: “...el corregidor, una de las piezas clave de nuestra Administración del Antiguo Régimen. No es cierto que el corregidor fuera una creación de los Reyes Católicos; la figura del delegado regio existía en épocas anteriores, por lo que la única novedad aportada por Isabel y Fernando fue la generalización de sus nombramientos en el Reino de Castilla. En el corregidor se concentran competencias militares, judiciales, fiscales y administrativas, como el Ayuntamiento cabeza de partido y mediatiza, en el caso de los Corregidores Mayores, las instrucciones de la ciudad a sus Procuradores en Cortes. El cargo era temporal y no venal".

${ }^{17}$ PIZARRO NEVADO, R. op. cit, pág. 25. 
primeros les corresponde un alcalde pedáneo y a los segundos un alcalde de barrio. Una tercera forma de organización agrupaba minúsculas poblaciones organizadas como corporaciones cerradas o ayuntamientos. Cada uno de estos pueblos constituía una unidad administrativa que respondía al nombre de Concejo (o Parroquia en Asturias y Galicia $^{18}$. Los Ayuntamientos se integraban por una agrupación de Concejos. Cada uno de ellos se estructuraba orgánicamente con un Regidor, que al tiempo que dirigía la administración del anejo, representaba al Concejo en el Ayuntamiento. Las primeras informaciones publicadas sobre la existencia de este tipo de entidades menores, nos indica ORDUÑA REBOLLO ${ }^{19}$, datan del Censo de 1593 y posteriormente del realizado en el S. XVIII por el Conde de Floridablanca.

Este primer acercamiento a estas realidades, como ha señalado COSCULLUELA MONTANER no lo podemos hacer únicamente desde la legislación en vigor, si no que hay que profundizar en su "encuadre socioeconómico y en el estudio de su evolución histórica. De otra forma quedarían sin explicar las causas y presupuestos de los numerosos problemas que presentan" ${ }^{, 20}$.

\footnotetext{
${ }^{18}$ MARTINEZ MANOVEL, C./PEDREIRA GARCIA, J. op. cit. pág. 3495: Este Concejo pleno o general de vecinos impregna toda la actividad de estas comunidades y se convierte en el centro vital de cada una de ellas. En torno a él gira toda la vida de sus miembros. El concejo gestiona y administra sus propios recursos, canaliza problemas, acuerda soluciones y desarrolla tanto las actividades colectivas propias de la sociedad rural campesina como las actividades lúdicas: reparto anual entre los vecinos cabezas de familia del quiñón de leña, hacenderas y trabajos colectivos, distribución vecinal de lotes de tierra en quiñones, socialización y colectivización del agua, caza, pastos, etc... [... El concejo es de obligada convocatoria por parte de sus cargos oficiales y de obligada asistencia para los hombres cabeza de familia. Del concejo general de vecinos emanan los oficios o cargos concejiles que han de gobernar cada comunidad. Estos cargos concejiles con contemplados como un servicio a la comunidad, como un deber de cada vecina en contrapartida a los derechos que la comunidad le reconoce a través del concejo. [...] Los oficios concejiles que gobernaron estos lugares fueron los alcaldes de concejo y de la Santa Hermandad, los regidores concejiles y el procurador general.
}

${ }^{19}$ ORDUÑA REBOLLO, E. "Las entidades de ámbito territorial inferior al municipio. Del pasado al futuro", en El Derecho Administrativo S. XXI. Fco. Sosa Wagner (Coord). Homenaje al Dr. D. Ramón Martín Mateo. 2000. Pág. 745

${ }^{20}$ COSCUlluela MONTANER, L., voz en Junta Vecinal en "Nueva Enciclopedia Jurídica Seix" XIV, Barcelona. 1978, pág. 296. 


\section{2.- Periodo constitucional en el Siglo XIX}

Avanzamos hasta los primeros años del constitucionalismo español para encontrarnos, en la Constitución de Cádiz de 1812, la previsión de creación de Ayuntamientos a partir de un número determinado de habitantes que se cifró en $1.000^{21}$. PIZARRO NEVADO señala que con anterioridad a la Constitución de Cádiz no es posible una distinción clara entre la entidad inframunicipal como hoy se concibe y otras figuras. $^{22}$

Lo que se pretendía era una profunda reforma del régimen local, y la abolición de los señoríos jurisdiccionales, lo cual se pretendió con la unificación de la creación de ayuntamientos y la eliminación de cualquier privilegio ${ }^{23}$.

Pero en contra de estas buenas intenciones quedaron sin resolver la situación de numerosos pueblos que no alcanzaron la categoría de Ayuntamientos. Por lo que en aquellos pueblos menores a los 1.000 habitantes que no solicitaron su trasformación en Ayuntamientos o que fueron denegadas, siguieron agregados a los Ayuntamientos al que lo habían estado ${ }^{24}$. Se observa una clara intención de subordinación al Poder Central. Dentro de ese modelo racionalista y uniformador no se preveía la creación de entidades inframunicipales, la vida local se articulaba exclusivamente en torno al Ayuntamiento. La Constitución de Cádiz supuso también la supresión del régimen de perpetuidad de oficios y de los privilegios de la nobleza ${ }^{25}$.

Dicha norma constitucional fue desarrollada por los Decretos de 23 de mayo y de 10 de junio de 1812, como se verá más adelante, y como veremos también a los dos

\footnotetext{
${ }^{21}$ El desarrollo de esta previsión lo encontramos en la Instrucción para el gobierno político económico de las provincias de 23 de junio de 1813 que, con referencia a las obligaciones y cargos de las Diputaciones Provinciales, las encomendaba el cuidado del establecimiento de Ayuntamientos en los pueblos donde no los haya... y tomar razón del vecinadior de cada pueblo donde haya de establecerse el ayuntamiento...".

${ }^{22}$ PIZARRO NEVADO, R., "Las Entidades de ámbito territorial inferior al municipio”, Homenaje al Dr. D. Ramón Martín Mateo. T. 1-2000.

${ }^{23}$ Decreto de 6 de junio de 1811, lo que provocó la necesidad de crear nuevos municipios allí donde no existían.

${ }^{24}$ Vid. ROSA MORENO, J. “Aproximación histórica a la articulación orgánica de los núcleos separados de población”. Revista de estudios locales y autonómicos, $n^{\circ} 262$. Madrid. 1991. Pp. 219-246.

${ }^{25}$ SOSA WAGNER, F. Vid. Op cit. “Manual.....”, pág. 32.
} 
años de éstos acontecimientos, con la vuelta del absolutismo, y mediante la Real Cédula de 30 de julio de 1814, se ordena la disolución de los Ayuntamientos constitucionales y se restablece los Ayuntamientos, Corregidores y Alcalde mayores en la planta que tenían en 1808 .

Posteriormente y durante el llamado "trienio liberal” se aprobó la Instrucción para el gobierno económico y político de las Provincias de 3 de febrero de 1823, y aquí encontramos la existencia de una breve regulación de los núcleos separados de población, mediante la creación de un órgano unipersonal, que dependiendo del municipio, solo tendrá las funciones de enlace e información con éste. Pero dicha Instrucción tuvo también una existencia muy breve, ya que fue abolida en apenas un año. La Instrucción de 1823 (considerada la primera ley de régimen local $^{26}$ ) establece un reconocimiento explícito a la existencia de unidades territoriales y poblacionales tales como barrios, aldeas, lugares, caseríos separados, que no reúnen la condición de ayuntamiento pero están reconocidas como parte integrante de estos (designando un Capitular vecino de ellos o en su ausencia un Celador).

En el año 1833, Javier de Burgos, Ministro de Fomento en la época, consigue hacer la división territorial en provincias que perdura hasta nuestros días. Además se crea la figura de los Subdelegados del Gobierno en las provincias. Y se produce también la subdivisión en partidos judiciales de la nueva división territorial en 1834 (Real Decreto 21 de abril de 1834). Y es en este Real Decreto donde aparecen por primera vez, en su apéndice, que los partidos judiciales incluyen a los pueblos y parroquias. En el Real Decreto de 23 de julio de 1835 se establece que en los pueblos o parroquias rurales donde las dificultades del terreno u otras circunstancias lo justificasen, podrían nombrarse tenientes de alcalde, de entre los vecinos y moradores del distrito, donde señala ORDUÑA REBOLLO “que algún autor ha creído encontrar el germen de los Presidentes de las Juntas administrativas posteriores ${ }^{27 "}$.

\footnotetext{
${ }^{26}$ ORDUÑA REBOLLO, E. "De los pueblos y aldeas a las Entidades Locales Menores". Revista Carta Local FEMP $n^{\circ}$ 150. 2003. pág, 40.

${ }^{27}$ ORDUÑA REBOLLO, E. op. cit. “Las entidades de ámbito territorial......” Pág. 760.
} 
Desde 1836 hasta la renuncia de la Reina $\mathrm{M}^{\mathrm{a}}$ Cristina, se elaboraron dos proyectos de ley de Ayuntamientos, uno en 1838, el cual y dentro del objeto de estudio que nos ocupa, dispuso la existencia de un alcalde pedáneo para las parroquias o poblaciones rurales elegido por el alcalde, y además previendo la posibilidad de que el Gobierno pudiera crear alcalde pedáneo en cualquier barrio separado de la población. El otro proyecto de ley, si bien no hacía referencia a los pueblos, regulaba las competencias del alcalde pedáneo, análogas a las del alcalde del ayuntamiento, pero bajo las órdenes de éste. Ninguno de los proyectos pudo prácticamente ser alumbrado.

Durante la época moderada la decadencia municipal fue en aumento, restringiéndose la autonomía municipal hasta casi eliminarla por completo. Pero la norma más negativa para los municipios fue sin duda la Ley de 1 de mayo de 1855 sobre desamortización general, que afectó a los bienes de propios de los pueblos provocando una ruina casi total en los mismos.

En la época del bienio liberal se aprobó la Ley de 24 de junio de 1856, la cual equipara a los pueblos que no constituyen municipio con los barrios en que se dividían las ciudades, los cuales serán regidos por un Alcalde Pedáneo nombrado libremente por el Alcalde, de entre los vecinos del distrito, pueblo o barrio. En todo este proceso la tendencia era la de creación de nuevos municipios incluso a través del mecanismo de la segregación, pero no se regulaban las entidades inframunicipales, como mucho, los núcleos separados de población se configuraban como órganos de gobierno desconcentrados.

Será al llegar el año 1870 cuando se presta a la existencia de prácticas descentralizadoras, y en ese contexto se aprueba la Ley de 20 de agosto de 1870, donde se regula en su Título III, capítulo 2 "De la administración de los pueblos agregados a un término municipal ${ }^{28, "}$. En dicha regulación a esos pueblos con territorio propio, pastos, montes etc... se les reconoce el derecho a conservar la administración

\footnotetext{
${ }^{28}$ GIRADO CID, C. "Las entidades locales menores: Antecedentes legislativos y regulación actual. Régimen murciano". Anales del Derecho. Universidad de Murcia. Murcia. 1991, n 11, pág. 239, afirma que dicha ley es la primera que se ocupa del régimen de estos pueblos, coincidiendo con que el sufragio universal viene a constituirse en la fórmula de provisión de los cargos concejiles.
} 
particular $^{29}$. Dicha misión se encomendaba, como más adelante veremos, a una Junta compuesta por un Presidente y dos o cuatro vocales (en función del número de vecinos) elegidos directamente por los vecinos del pueblo. En la Ley de 2 de octubre de 1877 se reprodujo dicha regulación ${ }^{30}$, como veremos al estudiar dicho texto legal, y se mantuvo hasta 1924, paso importante pues se reconoce ya por primera vez y de forma expresa el reconocimiento de este tipo de entidades locales.

Así llegamos al Estatuto Municipal de Calvo Sotelo del año 1924 (en adelante EM), pero antes de entrar a mencionar brevemente el contenido sobre el tema que nos ocupa que dispone el Estatuto, debemos hacer una pequeña mención al Proyecto de Ley Municipal de Maura del año 1907. En este texto normativo, a los pueblos agregados a un término municipal se les reconocía personalidad como sociedades naturales y se regulaba su régimen y funcionamiento. Las Juntas Administrativas de 1877 pasan a denominarse "Juntas de Vecinos" y se les reconocía expresamente la capacidad de adquirir, conservar, enajenar los bienes peculiares, y celebrar contratos o ejercitar acciones relacionadas con ellos. Durante el debate de dicho proyecto, y centrándonos en el Capitulo V regulador del tema referente a las Juntas de Vecinos, destaca ORDUÑA REBOLLO la intervención del Diputado de La Bañeza (León), Sr. Pérez Crespo, el cual propone que la Junta fuese presidida por un alcalde pedáneo y fuesen vocales todos los residentes en el anejo o pueblo. Solución de democracia directa que es apoyada por el Diputado por Palencia Sr. Calderón, el cual afirma que el nombre técnico con el que se conoce en Castilla a la Junta de Vecinos es el Concejo Abierto. Por otra parte en el proyecto de Barroso de 1912, con el nombre de "anejo", se definen los poblados, aldeas o caseríos que tuvieran terrenos propios, aguas, montes o cualquier derecho peculiar, reconociéndoles una amplia capacidad jurídica, que incluye la conservación y disposición del patrimonio, la contratación y el ejercicio de acciones; si bien en todo caso, su existencia legal se hace depender de la decisión política del Ayuntamiento ${ }^{31}$.

\footnotetext{
${ }^{29}$ GARRIDO FALLA, F. op cit. Pp. 690-691.

${ }^{30}$ En esta ley no aparecen aún las entidades locales menores como categoría, conservándose la regulación de núcleos separados de población en los art. 90 a 96 con la denominación de "pueblos agregados".

${ }^{31}$ GUIRADO CID, C. op. cit. pág. 242.
} 
Siguiendo a PIZARRO NEVADO, durante esta época de inestabilidad política y constante reforma legal, destaco la existencia también de algunas realidades paralegales que se perpetuaron a los largo de los S. XIX y XX como las parroquias rurales gallegas y asturianas, configuradas como agrupación de aldeas que han constituido tradicionalmente una fáctica unidad administrativa ${ }^{32}$.

\section{3.- Periodo constitucional del Siglo XX}

\subsection{1.- El Estatuto Municipal de 1924 y las Entidades Locales Menores}

Aprobado por Decreto Ley de 8 de marzo de 1924, en este texto normativo se reconoce al municipio como entidad natural, afirmando en su preámbulo que es la constatación de un hecho social anterior al Estado y a la misma ley ${ }^{33}$. Se asigna por primera vez la denominación de "Entidad Local Menor", concepto que ha perdurado hasta nuestros días, y que comprende aquellos anejos, parroquias, lugares, aldeas, caseríos y poblados que estando dentro de un municipio pero formando núcleo separado forman a su vez un conjunto de personas y bienes con intereses propios separados de los del propio municipio (art. 2 a 4 y 105 a 109). Además se les reconoce también de manera expresa capacidad jurídica plena para la adquisición y enajenación de bienes, contratación, establecimiento de servicios y ejercicio de acciones, contenidos que, con más o menos variantes, se mantendrán hasta nuestros días. Se permitía el reconocimiento de las entidades existentes y reguladas por la legislación anterior y además se regulaba el procedimiento de creación de nuevas entidades de esta naturaleza $^{34}$. El tránsito de la condición de pueblo agregado a la de entidad local menor era prácticamente automático y se regulaba en la disposición transitoria octava del EM, donde se establecía que los anejos o agregados adquirían ex lege la naturaleza de

\footnotetext{
${ }^{32}$ PIZARRO NEVADO, R. op. cit. pág. 38.

${ }^{33}$ GUIRADO CID, C. op. cit. pág. 242: afirma que será este Estatuto Municipal el que en congruencia con su declaración de "máximo respecto a la realidad social" el que proclamará el carácter comunal no sólo del municipio, sino también de las "entidades menores o fracciones de municipio", y es a partir de este texto cuando se delimitan de forma clara e inequívoca los perfiles y caracteres de las entidades locales menores, en cuanto administración descentralizada con personalidad jurídica propia para la asunción de sus competencias específicas.

${ }^{34}$ GUIRADO CID, C. op. cit. pág. 243: Se establece un reconocimiento "ex lege" de las existentes con el nombre de "anejos o agregados" conforme al art. 90 de la Ley municipal de 1877, y las de nueva creación se sujetan a un procedimiento que, en esencia, se mantendrá constante hasta el trámite de resolución.
} 
las Entidades Locales Menores, gozando de plena personalidad "sin necesidad de petición por los interesados, ni de reconocimiento por las Corporaciones municipales”.

Tanto la creación de las nuevas entidades, como el reconocimiento de las ya existentes se regularon por el Reglamento de Población y Términos Municipales aprobado por el Real Decreto de 2 de julio de 1924. En este Reglamento se encuentra, tal como dice PIZARRO NEVADO, el verdadero engarce entre las Entidades Locales Menores y el régimen de los pueblos agregados ${ }^{35}$.

El EM es un texto legal adelantado a su tiempo, innovador y de regulación plena, pues intenta llegar a todas las esquinas de la vida municipal. Comienza ya con un art. 2 prometedor en cuanto al régimen de las entidades objeto de nuestro estudio, pues ya se llaman por primera vez Entidades Locales Menores, como hemos dicho. Importantísimo es el artículo 2 que, aparte de conceder ya la denominación por la que actualmente conocemos a estas entidades, reconoce las distintas manifestaciones de convivencia social existentes en nuestro país, es decir, estas entidades no son un efecto del legislador, si no una constatación de un hecho social de convivencia anterior al Estado mismo, y anterior por ende a la misma ley ${ }^{36}$. Ésta última se limita a reconocerlos en sus diferentes grados, ya que, como señala la Exposición de Motivos del Estatuto, la convivencia se da en núcleos de gradación ilimitada, desde los insignificantes, con unas pocas docenas de vecinos, hasta los gigantescos que cuentan por millones sus habitantes.

Resulta llamativo que el propio texto, al denominar a estas entidades como Entidades Locales Menores, también las llama "fracciones de Municipio". Lo que sí que deja claro es que están y existen dentro de un municipio, lo que marcará su ámbito de funcionamiento como último escalón de la división administrativa existente en nuestro país.

\footnotetext{
${ }^{35}$ PIZARRO NEVADO, R. op. cit. pág. 41.

${ }^{36}$ La Exposición de Motivos del Estatuto Municipal manifiesta que: “... El nuevo Estatuto admite la personalidad municipal allí donde la Naturaleza la engendra, sin establecer requisitos de mero artificio...".
} 


\subsection{2.- Las entidades locales menores en el periodo republicano}

En este contexto histórico es de una gran relevancia hacer mención a la norma constitucional que se aprobó entonces, es decir, la Constitución de 1931, norma que por primera vez reconoce el principio de autonomía de los municipios para la gestión de sus competencias, reconoce el régimen de Concejo Abierto y establece la elección democrática de los alcaldes.

Si bien en esta norma suprema no se hace mención a otras entidades menores, quizás, como dice ORDUÑA REBOLLO “para hacer más palpable su origen y base de organización" (la del municipio), se mantiene la idea ya recogida en el EM, de entidad natural del municipio. En este periodo de nuestra historia se produce un hecho legislativo de notable importancia como es el de la aprobación del "Estatuto de Autonomía de Cataluña de 1932”. Además y en este orden de cosas, se produce la redacción de un proyecto de ley municipal en dicha región. En aquella se habla de "submunicipios" $" 37$, refiriéndose a los grupos de población o pueblos que dentro de un municipio constituyen núcleo separado de edificación, con intereses particulares y una población de un mínimo de 200 habitantes ${ }^{38}$.

En 1935 se aprueba una nueva Ley Municipal dentro del régimen vigente ${ }^{39}$. Esta norma incluía a las ELM en la clase primera junto con los municipios (art. 2, 3, 18 a 22). Como una de las escasas novedades se refiere al procedimiento de creación y supresión que más adelante veremos. No se regula la competencia de estos entes aunque sí se las reconoce jurisdicción territorial y separación patrimonial, manteniéndose las entidades locales menores existentes al tiempo de la entrada en vigor de este texto.

\footnotetext{
37 Ley municipal catalana de 14 de agosto de 1933. Dicha norma reconoce a las Corporaciones municipales la competencia para crear entidades autónomas submunicipales.

${ }^{38}$ ORDUÑA REBOLLO, E. op. cit “Las entidades de ámbito territorial...” pág. 759: La Ley Municipal de Cataluña hace una salvedad importante, excluyendo a los santuarios, comunidades religiosas, empresas industriales, mercantiles o donde existiese un propietario poseedor de la quinta parte del terreno o que el total perteneciese a menos de diez propietarios.

${ }^{39}$ ORDUÑA REBOLLO, E. op. cit “Las entidades de ámbito territorial......”, pág. 761.: "Considerada dicha ley como un retroceso ante la calidad técnica y el grado de autonomía municipal teórica del EM".
} 


\subsection{3.- Las entidades locales menores y el autoritarismo}

La nueva situación creada en nuestro país tras la guerra civil de 1936 a 1939 acabaría con cualquier intento de autonomía, y por tanto también con la autonomía local. Se intentan adaptar los Estatutos de Calvo Sotelo a la nueva situación, pero no alcanzarán las cotas de autonomía en ellos contenida. En 1945 se aprueba la nueva Ley de Bases de Régimen Local. Si bien en los textos anteriores hemos observado la intención de los legisladores de reconocimiento y/o creación de nuevas ELM siempre dirigidos al mantenimiento de estas realidades sociales ${ }^{40}$, en esta norma comienza en su Base $4^{\mathrm{a}}$ con las frase "Podrán ser suprimidas aquellas Entidades Locales Menores..." 41 , o bien cuando no tuvieran medios para mantener los servicios mínimos de policía urbana y rural, o bien por motivos de conveniencia o necesidad, ya sea de carácter administrativo o económico. Si bien en la Base $7^{\mathrm{a}}$ también se recoge el reconocimiento expreso de las "Juntas Vecinales" que tradicionalmente vinieran funcionando. Como novedad que veremos más adelante, se incluye la obligación que se impone a las Juntas Vecinales de obtener ratificación por parte de los Ayuntamientos a los que pertenezcan, en aquellos acuerdos que afecten a la disposición de bienes, operaciones de crédito y expropiación forzosa.

Posteriormente se aprueba el Texto Refundido de Ley de Régimen Local en el año 1955. Este texto reconoce a las Entidades Locales Menores como entidades naturales constituyentes del municipio ${ }^{42}$. Si bien ha sido criticado por algunos autores que el legislador del momento no comprendió la realidad de estos núcleos de

\footnotetext{
40 Estas entidades serán objeto de una atención más detenida en el Reglamento de Población y Demarcación Territorial de 1952.

${ }^{41}$ GARRIDO FALLA, F. op cit. pág. 697. Critica el autor a este texto normativo al considerarlo "un retroceso".

${ }^{42}$ Se impone en este texto normativo, respecto de las ELM, un estricto régimen de dependencia del municipio en que se integran, supeditando la existencia de la entidad menor al hecho de que cuente con medios económicos suficientes para prestar los servicios mínimos obligatorios, alterando el carácter electivo de sus órganos de gobierno y exigiendo la necesaria aprobación por el Ayuntamiento de las decisiones tomadas por la Junta Vecinal en todos los actos fundamentales de la vida de la entidad inframunicipal.
} 
población $^{43}$. La enumeración de competencias que se recoge en esta norma, ha sido mantenida prácticamente igual en la legislación democrática actual ${ }^{44}$.

Los reglamentos de desarrollo de este texto normativo del año 1955, tienen en el Estatuto Municipal su fuente de inspiración, tomando de él cuantas instituciones y aspectos resultan compatibles con una concepción esencialmente centralista del Estado.

Si bien el control de las mismas queda supeditado al poder central, ya se ve cuando en el art. 23 se definen estas entidades introduciendo un dato claramente indeterminable como es la exigencia en la entidad de "características peculiares", viéndose, incluso en el reconocimiento de las existentes, comprometido por este condicionante. Como el régimen político de la época seguía cerrado a cualquier connotación de carácter democrático, en 1971 se presentó un proyecto de Ley de Bases de destino frustrado donde se cambiaba el nombre de Entidades Locales Menores por "Comunidades Municipales Menores", y en la Ley de Bases de Régimen Local de 1975 solo se mencionaban en la base $1^{\circ}$ al incluirlas dentro de la Administración Local, nada más.

\subsection{4.- La llegada de la democracia}

La Ley de Bases del Estatuto de Régimen Local 41/1975 de 19 de noviembre, se promulga un día antes del fallecimiento del General Franco, y tiene como finalidad fundamental la vuelta al sufragio universal activo y la elegibilidad del Alcalde, y reconoce que el municipio y la provincia son entidades fundamentales de la administración local y señala, como relevante, que también forman parte de ella las

\footnotetext{
${ }^{43}$ VALENZUELA GARCIA, F. "Entidades municipales territoriales. El municipio y la entidad local menor". Granada. 1964. Pág. 142: Cita el autor unas conclusiones con relación al régimen jurídico recogido respecto a estas ELM en la ley de 1955 que recojo por lo interesante de las mismas: “- La ELM es una realidad de nuestra vida local. El legislador ha de actuar al regularla conforme a tal realidad. Critica el autor que esa no ha sido finalmente la verdad, y que la ELM ha quedado en pura entelequia. - $\mathrm{Si}$ constituye una entidad sustantiva, sus competencias han de estar acorde con ella. Por tanto, la injerencia del municipio debe limitarse a una tutela, a una cooperación que no intervengan partidismos de ningún índole".

${ }^{44}$ PIZARRO NEVADO, R, op. cit. pág. 46: “... el precepto no recogía una cláusula general por la que se les atribuyan los fines generales de la comunidad que encuadran. Parte, por tanto, del principio de que esos fines generales son propios del municipio, correspondiendo a la Entidad local menor exclusivamente los enumerados en el art. 107 LRL".

La Ley de 1955 atribuye a las ELM las siguientes facultades: construcción, conservación y reparación de fuentes y abrevadores, policía de caminos rurales, montes, fuentes y ríos, limpieza de calles, administración y conservación de su patrimonio, incluido el forestal, y la regulación del aprovechamiento de sus bienes comunales, así como la prestación de los servicios comprendido en la competencia municipal y de exclusivo interés de la entidad cuando no los tenga a su cargo el respectivo municipio.
} 
ELM. La instauración del nuevo régimen democrático en nuestro país abre además un nuevo mapa territorial. El instrumento para la viabilidad de los nuevos cambios será la norma máxima del ordenamiento, se aprueba una nueva Constitución que reconoce, entre otras cosas, la autonomía de las entidades locales territoriales.

Uno de los primeros pasos de apertura al reconocimiento e institucionalización de pueblos, aldeas y parroquias, fue el reconocimiento constitucional del régimen del Concejo Abierto, traduciéndose en la confirmación del sistema de autogobierno libre y democrático, no sólo de los municipios menores de 100 habitantes, sino de la mayoría de las ELM.

A partir de 1979 las entidades locales eran gobernadas por corporaciones elegidas de manera democrática y en cuanto al régimen jurídico aplicable en dicho momento si bien era disperso, no se estaba carente de él, ya que se había mantenido preceptos de la legislación anterior revisados por el Tribunal Constitucional, y también la existencia de normas transitorias que enlazaron con la posterior Ley de Bases de Régimen Local de 1985. Entre dicha normativa podemos mencionar el Real Decreto 1710/1979 de 16 de junio por el que se liberaliza la fiscalización, intervención y tutela ministerial, el Real Decreto Ley 3/1981 por el que se suprimen los controles y autorizaciones en materia de personal, presupuestos y régimen tributario de las corporaciones locales.

Podemos también aludir al proyecto de Ley de Bases de Administración Local de 1981, obra del gobierno de UCD que no llegó a cristalizar en ley ${ }^{45}$. Se definen en él a las ELM como las constituidas con tal carácter y los núcleos de población tradicionales en la vida local española legalmente reconocidos y que formen núcleos separados de población, sean parte integrante de un término municipal y cuenten con organización propia para la gestión de sus intereses peculiares.

\footnotetext{
${ }^{45}$ Los artículos 8 y 12 del proyecto decían que la constitución de las ELM se somete a los requisitos económicos de contar con patrimonio propio y con recursos suficientes para la satisfacción de sus necesidades, y la autorización del Ministerio de Gobernación se sustituye aquí por la de las CCAA, en concordancia ya con el art. 148.1.2 CE.
} 
Posteriormente se produce la aprobación de la actual y en vigor Ley de Bases de Régimen Local 7/1985, de 2 de abril. Respecto de las ELM al no estar amparadas por la garantía constitucional sí reconocida para municipios, provincias e islas, deriva que la constitución de las mismas sea potestativa, siempre que se cumplan los requisitos previstos para la misma y desarrollados por la legislación autonómica. Es en el art. 3 de la LBRL donde se hace su reconocimiento junto con los municipios, provincias e islas (entidades territoriales) a las entidades de ámbito inferior al municipio (EATIM) ${ }^{46}$. En el art. 45 se refería al régimen de estas EATIM, remitiéndose la regulación de las mismas a la legislación autonómica. Posteriormente el Texto Refundido de Régimen Local de 1986, aprobado por Real Decreto Legislativo 781/1986 desarrolla más ampliamente lo concerniente a competencias, proceso de constitución, modificación o supresión de estas entidades. La voluntad constitucional de organizar territorialmente nuestro país en Comunidades Autónomas, Provinciales, Municipios y otras entidades, tales como las que son objeto de nuestro estudio, se enfrenta con la incapacidad de estas últimas de prestar los servicios mínimos establecidos por la Ley. La tradición, como dice DIEZ GONZALEZ ${ }^{47}$, ha quedado desfasada ante las exigencias de los tiempos y esa misma tradición presenta resquebrajos tanto en las instituciones como en las personas.

\footnotetext{
${ }^{46}$ Nueva denominación con la que se reconoce a estas entidades y que aglutina a la pluralidad de instituciones que pueda existir.

${ }^{47}$ DIEZ GONZALEZ, A. "La comunidad de aldea". 1974. pág. 213. "El ánimo es lo que importa. El ánimo de situarse más al día [...] pero resulta paradójico que ante las mayores posibilidades de cada día legales y técnicas, se malogre tantas cosas y se oscurezca en una rutina y una desidia que se traduce en abandono.".
} 


\section{3.- CREACIÓN Y ORGANIZACIÓN}

\subsection{Creación de las entidades locales menores}

Para abordar este capítulo y entender la propia razón de ser de estas entidades, debemos señalar que lo determinante es que las mismas tengan personalidad jurídica reconocida, y así es por el hecho de ser Administraciones Públicas, tal y como señala el art. 2.2 de la Ley 30/1992, de 26 de noviembre (LPAC), en la actualidad.

GUCLIERI NAVARRO ${ }^{48}$ afirma al hablar de este tema que lo importante no es que existan muchas Entidades Locales, si no que las que existan sean capaces de satisfacer las necesidades del pueblo, es decir, no justificar la creación por la creación, si no que responda al sustrato o realidad sociológica. Fundamentalmente, como veremos, estos entes existen y han existido tradicionalmente para gestionar unos bienes. Por lo tanto necesitan personalidad jurídica, y es el ordenamiento jurídico quien se la atribuye.

Analicemos pues las peculiaridades respecto a su creación, afirmando que la misma necesita de una disposición que o bien las reconozca o bien las atribuya la existencia misma, y eso a diferencia de las provincias y los municipios, que su existencia viene recogida en la propia ley. A lo largo de la evolución histórica, observaremos los cambios y regulaciones en cuanto a la creación de este tipo de entidades. Así, comenzamos en el año $1924^{49}$, con el Reglamento de Población y

\footnotetext{
${ }^{48}$ GUGLIERI NAVARRO, A. "Notas para un reajuste-concepto de entidad local menor". Revista de estudios de administración local y autonómica. no 80. Madrid. 1955. Pág. 245.

${ }^{49}$ Reseñable es la Sentencia 15 de junio de 1928, la cual establece una clasificación importantísima que ya hemos visto al analizar el derecho histórico en cuanto al tema del reconocimiento de estas entidades, y que es la de:

- Entidades existentes de hecho y de derecho (Clasificación realizada desde el punto de vista de su existencia legal y con relación a su reconocimiento por el Estatuto municipal, en entidades ya existentes de hecho y de derecho al tiempo de su promulgación y que este se limita a reconocer expresamente afirmando su personalidad, cual acontece con las Juntas Vecinales reconocidas por la Ley Municipal de 1877 en sus art. 90 y 91, y que el Reglamento de Población de 1924 en su art. 4
} 
Término Municipales, de 2 de junio de 1924, el cual en su art. $2^{\circ}$ sólo exigía, para la creación de esta entidades, acuerdo firme de reconocimiento por parte del mismo (reconocimiento obligatorio por parte del Ayuntamiento cuando se daban ciertos supuestos, puesto que no cabía la negativa municipal a reconocer esa realidad fáctica). Sería potestativo para el Ayuntamiento cuando se trate de núcleos rurales inferiores a los señalados en el párrafo segundo del propio artículo dos ${ }^{50}$. Se distinguía en esta norma entre:

Procedimiento previo al reconocimiento: en éste se necesitaba la petición por escrito de la mayoría de los vecinos (incluso se permite firmar por los que no saben ${ }^{51}$ ), y copias de ese escrito se exponían al público en las puertas de la Casa Consistorial, del Juzgado Municipal y de las Iglesias parroquiales o anejas que estén dentro del núcleo. En dicha petición se deberán especificar cuáles son los derechos o intereses que caracterizan a esa agrupación y sobre dichas condiciones puede pedirse informe al Párroco, al Juez Municipal o a cualquiera otra autoridad local. El acuerdo de reconocimiento de la ELM lo adoptaba el Ayuntamiento y contra el mismo sólo cabía recurso ante el Tribunal contencioso administrativo Provincial.

Procedimiento posterior: este procedimiento se refiere más bien a los trámites que había que seguir una vez el Ayuntamiento hubiera acordado el reconocimiento de la entidad y este acuerdo fuera firme, se haya insertado en el Boletín Oficial de la Provincia y

reconoce plena personalidad jurídica como tales entidades locales menores, sin necesidad de petición por los interesados, ni de reconocimiento por las Corporaciones Municipales).

- Entidades existentes solo de hecho, al tiempo de promulgación de la norma, a las que el Estatuto atribuye condiciones para ser reconocida su personalidad legal administrativa, por responder a una verdadera realidad social, con todas las facultades y derechos que de tal reconocimiento se derivan en el orden legal, cual acontece con las comprendidas en el art. 2 del citado Reglamento: parroquias rurales, concejos abiertos de carácter tradicional, antiguos municipios anexionados y núcleos rurales inferiores a los enumerados.

${ }^{50}$ TORRES CURDI, ob cit. Pág.89: "Hemos de tener en cuenta que, al no dar cifra de población, puede ocurrir que, a un grupo con más habitantes que otro, le sea denegada, por la circunstancia de no reunir las características que en el mismo se indican y como en el artículo segundo del EM se hace referencia a número, entendemos que en este caso la discrecionalidad del Ayuntamiento es muy amplia, porque el precepto hace referencia al término "inferiores" y no a otra nota".

${ }^{51}$ Se permite que si la Alcaldía tuviera dudas acerca de la autenticidad de las firmas, pueda exigir comparecencia y ratificación de los interesados, salvo que el escrito de petición esté autorizado por un Notario. 
comunicado a las autoridades preceptivas ${ }^{52}$. Dicha comunicación debería contener los extremos relativos a la delimitación del territorio y del patrimonio correspondiente.

Existencia de ELM sin necesidad de procedimiento constitutivo: el art. 4 de la norma citada, manifiesta que aquellas entidades que según la Ley de 1877 venían funcionando como anejos o agregados tendrán plena personalidad jurídica como ELM y no haría falta, por tanto, de ningún acto de reconocimiento ni petición por parte de las mismas. El derecho a aplicarles sería por tanto el establecido en el Estatuto Municipal de 1924.

En cuanto a requisitos a cumplir para poder acogerse a este régimen, nos encontramos con:

○ no podrán pertenecer a jurisdicciones distintas del mismo orden;

○ aquellas parroquias o entidades cuyo territorio pertenezca a ayuntamientos diferente previamente deberán precisar el municipio a que deseen pertenecer.

En la Ley Municipal de 1935 se recoge que si el acuerdo del Ayuntamiento es favorable a la constitución de la ELM bastaría con que se pronuncie para autorizarlos; pero si fuera denegatorio, la resolución definitiva le corresponderá al Consejo de Ministros, oído el Consejo de Estado. Además esta Ley reconocía como ELM, además de los supuestos de creación, a todas aquellas que ya existían al promulgarse la misma. Además en esta norma ya aparece la prohibición o límite a que se constituyan ELM en las cabeceras de los términos municipales.

TORRES CURDI ${ }^{53}$ recoge los problemas fácticos ante los que se podían encontrar en diferentes supuestos casuísticos ante esta tesitura ${ }^{54}$, los cuales no han sido objeto de regulación en este camino de recorrido legislativo histórico y que procedemos a exponer aquí, ya que se pueden dar las siguientes situaciones:

\footnotetext{
52 Gobernador Civil, Presidente de la Audiencia, Delegado de Hacienda y al Jefe Provincial de Estadística.

${ }^{53}$ Op. cit. pág. 91.

${ }^{54}$ No son pocos los problemas de reconocimiento de personalidad de estas entidades que ha habido a lo largo de la historia. A tal efecto quiero destacar por su especial supuesto, la Sentencia de 26 de mayo de 1961, la cual manifiesta el reconocimiento de personalidad a las entidades locales menores al haber interpuesto recurso de reposición unos vecinos que precisamente la negaban, y dice el tribunal, que al reconocerles personalidad judicialmente por la vía indirecta de haber interpuesto el recurso, les están reconociendo esa misma personalidad que les niegan.
} 
- entidades de población que sean titulares de bienes pero que no se hayan constituido en ELM (si no se han reconocido o si los electores residentes no solicitan la constitución de dicho núcleo de población en ELM): en estos casos no les deberíamos aplicar el régimen común, pues si una de las particularidades que suelen tener todas estas diferentes agrupaciones poblacionales es que, como ya decía la Ley Municipal de 1877, conservarán sobre los bienes su administración particular;

○ perfilar la diferencia entre creación de las ELM y reconocimiento de las mismas; la Ley 1877 las llama "pueblos agregados a un término municipal”, el EM ya las llama ELM, y la ley de 1935 reconoce las que ya existían a su aprobación, es decir, las "legalmente constituidas", por lo tanto, para saber cuáles son debemos de retrotraernos al EM de 1924 y distinguir entre las ELM con población inferior a 1.000 habitantes que se regirán mediante Concejo abierto y las que superan los 1.000 habitantes, que se podrán regir mediante una Junta Vecinal;

○ en este último supuesto (el de reconocimiento) ¿cómo se sabe de la existencia previa? ${ }^{55}$.

- el problema de constitución de las ELM en las cabeceras (ya lo vimos al principio del tema y sigue siendo un problema en la actualidad): el Estatuto Municipal nada dice al respecto, pero la Ley de 1935 lo expresa categóricamente en su art. 21, asimismo y en la actualidad en la LBRL y TRRL también se recoge dicha prohibición.

Por lo tanto existía el reconocimiento-existencia, como lo llama TORRES CURDI, y el reconocimiento-constitución, un procedimiento, éste último, perfectamente delimitado para la constitución de las ELM. En la actualidad, como se verá, todo lo referente al procedimiento de constitución de estas entidades es materia que regulan las Comunidades Autónomas.

\footnotetext{
${ }^{55}$ En la Ley de 1935 se reconoce la existencia de las ELM, tanto de las que se constituyen conforme al EM como de las que se reconocen por existir ya según la Ley 1877, en virtud de la Disposición Transitoria $8^{\circ}$ del EM. Pero ¿cómo se prueba la existencia en esos casos?, ¿cómo acreditar que legalmente estaban constituidas en ese momento histórico?. TORRES CURDI afirma que se aplicaría la doctrina del silencio administrativo positivo, según dispone el Real Orden de 20 de septiembre de 1927
} 


\section{2.- Organización, administración y funcionamiento}

Vamos a verlo a lo largo de las normas del último tercio del siglo XIX y del XX:

\subsection{1.- Ley Municipal de 1877}

Apenas les dedica a estos entes unos artículos, ubicados en el Capítulo II del Título III, arts. 90 a 96. Como ya hemos visto los denomina "pueblos agregados a un término municipal', y únicamente en el art. 96 se remitía a la regulación prevista para los municipios si no había nada al respecto ${ }^{56}$. En cuanto a su organización, el art. 91 señala que para la administración de dichos pueblos se nombrará una Junta, que se compondrá de un Presidente y de dos o cuatro vocales, elegidos directamente uno y otros por los vecinos del pueblo y de entre ellos mismos ${ }^{57}$. Serán cuatro los vocales para los pueblos de 60 o más vecinos y dos cuando sea menor el vecindario. La elección de todos los miembros de la Junta deberá hacerse según la Ley electoral, trasladando al Ayuntamiento la ejecución de que ellos se lleven a cabo.

\subsection{2.- Estatuto Municipal de 1924}

En cuanto a la organización de las ELM, el EM en su art. 38 establece que para cada ELM existirá una Junta Vecinal, con la denominación que corresponda.

Asimismo y en el art. 105 y siguientes, se habla del régimen de las ELM. Aquí se distingue ya entre ELM de menos de 1.000 habitantes y de más de 1.000 habitantes:

- En aquellas el régimen de funcionamiento será el Concejo Abierto (aunque en el Ayuntamiento al que pertenezcan no se le aplique el mismo). Este Concejo

\footnotetext{
${ }^{56}$ Art. 96: La administración y la inspección expresadas, así como los deberes y las obligaciones de la Junta y de sus Vocales, se arreglarán a las prescripciones de la presente ley en todo lo que no se halla determinado en este capítulo.

${ }^{57}$ La elección de Presidente y Vocales indicadas se hará con arreglo a la Ley electoral, pero en un solo día y sin que trascurran más de ocho desde la posesión del Ayuntamiento del término, el cual cuidará de su ejecución. Elegidos los tres o cinco individuos para la Junta, corresponderá el cargo de Presidente a quien haya obtenido más votos, y si hubiera empate decidirá la suerte (art. 92 y 93). El art. 9 e) recoge las tachas para la elección de individuos de la Junta, con relación al pueblo respectivo, las mismas que establece esta Ley para el caso municipal.
} 
Abierto lo integrarán todos los electores de ambos sexos que residan en el territorio de la entidad.

La periodicidad de sus reuniones es la siguiente: se reunirán en asamblea al menos dos veces al año, y además siempre que o bien lo acuerde la Junta Vecinal o bien lo solicite una quinta parte de los electores ${ }^{58}$. Su composición es la que prosigue: regirá en las ELM en régimen de Concejo Abierto, una Junta Vecinal compuesta por un Presidente y dos vocales adjuntos. Se distinguen dos tipos de Junta Vecinal dentro de esta tipología:

○ vecinal: cuando se trate de anejo, poblado o caserío;

○ parroquial: cuando se trate de parroquia que geográficamente forme conjunto de casas separado del resto del municipio.

En cuanto a su funcionamiento, se afirma que a estas Juntas Vecinales y a los Presidentes de las mismas les serán de aplicación las disposiciones que el EM dispone sobre organización para los ayuntamientos, siempre que no sea contrarios a lo previsto en estos artículos para las Juntas Vecinales, ni contrario al uso, costumbre o tradición local.

- Las ELM cuya población exceda de 1.000 habitantes, y en especial las que formen barriadas o anexos urbanos agregados a grandes poblaciones, podrán regirse por una Junta Vecinal compuesta por tantos vocales como concejales le correspondería conforme al EM si fueran un municipio independiente.

La Junta Vecinal actuará de igual forma que la prevista para el Pleno de los ayuntamientos y nombrará al igual que se hace en los ayuntamientos, una "Comisión Permanente". De lo expuesto en este artículo, se advierte la posibilidad que se le ofrece a las ELM de adaptar el régimen de funcionamiento de los ayuntamientos, lo cual daría lugar a la paradoja de que en términos territoriales coincidentes tendríamos dos organizaciones prácticamente idénticas. Además el mismo artículo prevé que sea el

\footnotetext{
${ }^{58}$ Como señala Torres Curdi, op cit pág. 97: "pudiendo ser su convocatoria de oficio o bien a instancia de parte".
} 
Ayuntamiento el que pueda determinar la organización y funciones de las Junta Vecinales ${ }^{59}$.

El art. 190, de manera muy sucinta, casi como un resumen, enuncia las funciones de las Asambleas Vecinales:

○ elegir a la Junta Vecinal

- aprobar los presupuestos y cuentas ${ }^{60}$

- fijar las bases a que ha de ajustarse el aprovechamiento de los bienes comunales, si los hubiera.

El art. 191 recoge las competencias de las Juntas Vecinales, para que, y en nombre de la respectiva entidad, actúan:

○ aprobar Ordenanzas;

○ interponer acciones judiciales de todo género, promover procedimientos administrativos y económico-administrativos;

- conservar el patrimonio comunal, persiguiendo a los detentadores o usurpadores del mismo, y cuidar de la policía de los caminos rurales y vecinales, fuentes, ríos y montes con arreglo a los que dispongan las leyes.

\subsection{3.- Ley Municipal de 1935}

Aquí la administración especial estará a cargo de una Junta Administrativa, distinguiéndose a lo largo del articulado de esta ley, los siguientes órganos: Asamblea, Junta Administrativa, y dentro de ésta, el Presidente y los Vocales. La Asamblea la constituyen todos los vecinos que tengan condición de cabezas de familia, de ambos sexos. Esta Asamblea concejil se deberá reunir una vez al trimestre y siempre que lo acuerde la Junta Vecinal bien por sí o a petición de la quinta parte de sus electores. (art. 70). Respecto de la Junta, puede recibir diferentes nombres: vecinal, parroquial, administrativa, concejil, o cualquier otro usual en el país, tal y como señala el art. 67.2.

\footnotetext{
${ }^{59}$ TORRES CURDI, op. cit. 98: “...del precepto nada se deduce, pero del contexto del artículo parece lógico que la determinación del Ayuntamiento necesitará de la anuencia de la Entidad Local Menor”.

${ }^{60}$ Esta aprobación es sólo provisional, ya que la definitiva corresponde al Ayuntamiento.
} 
Para su constitución se parte de la renovación de los Ayuntamientos, fijándose la elección para el domingo siguiente a la constitución de estos, y la Junta se tiene que renovar cada tres años, al igual que los Ayuntamientos. Dicha Junta estará formada por un Presidente y dos Vocales titulares y dos suplentes, elegidos entre los vecinos que sepan leer y escribir, ajustándose al procedimiento tradicional y si no lo hubiera al mismo que para los Ayuntamientos. Les son aplicables las disposiciones reguladoras de constitución, gobierno, administración y funcionamiento que se aplican a los Ayuntamientos en todo aquello que no sea específico de éstos, ni se oponga al uso, costumbre o tradición de la entidad. Como funciones de dichos órganos están:

- Del Presidente: las mismas que para los Alcaldes en lo que se refiere al gobierno y administración de la entidad.

○ De la Asamblea: aprobación de presupuestos y cuentas.

\subsection{4.- Ley de 1955}

El art. 4 reconoce que la representación de la ELM le corresponde a la Junta Vecinal. Asimismo se define ya al Alcalde Pedáneo, el cual es nombrado por el Gobernador Civil de entre los vecinos cabezas de familia que residan en la Entidad. Dicho mandato lo será por tiempo indefinido y será el que presida la Junta Vecinal (art. $69^{61}$ ). Con respecto a sus atribuciones son muy similares a las del Alcalde pero limitadas al gobierno y administración de la ELM. Se prevé a su vez la existencia de la Asamblea Vecinal, la cual sólo la habrá en aquellas entidades que tradicionalmente vienen funcionando en régimen de Concejo Abierto, rigiéndose por su costumbre.

Por otra parte, como hemos visto, existe la Junta Vecinal, que está formada por el Alcalde pedáneo y dos vocales (nada se dice en esta ley sobre la posibilidad de existencia de "vocales adjuntos" como recogía la Ley de 1935$)^{62}$. Se nombran de entre vecinos cabezas de familia y son designados por los Concejales que constituyan la

\footnotetext{
${ }^{61}$ En las entidades locales menores habrá un alcalde pedáneo que presidirá las Junta Vecinal y será nombrado por tiempo indefinido por el Gobernador Civil de la Provincia, a propuesta del Alcalde del Municipio respectivo, entre vecinos cabezas de familia con residencia en la entidad.

${ }^{62}$ A los vocales se les aplica las mismas causas de incapacidad, incompatibilidad, excusas y causas de pérdida del cargo establecidas para los concejales (art. 84).
} 
Corporación Municipal (art. 76). Entre sus funciones están las relativas al gobierno y la administración y las relativas a los bienes. Todos los acuerdos sobre esta materia deben ser ratificados por el Ayuntamiento.

Los Concejales de los Ayuntamientos y los Vocales de las Juntas Vecinales se renovarán cada tres años, y les serán aplicables las causas de incapacidad, incompatibilidad, excusas y causas de pérdida del cargo establecidas para los concejales. Y si hablamos del régimen de organización de estas entidades tenemos que hacer referencia también al Reglamento de Organización, Funcionamiento y Régimen Jurídico de las Corporaciones Locales, el cual señala en su art. 89 que después de constituidos los ayuntamientos, estos elegirán, por mayoría de votos, a los vocales de las juntas vecinales de las ELM, de entre los vecinos que residan en ellas y sean cabezas de familia. El Alcalde Pedáneo tiene que prestar juramento ante el Alcalde del Ayuntamiento y puede ser sustituido en caso de vacante o enfermedad por el vocal que se designe a tal efecto. Vemos pues que ya está regulado el semillero de la regulación constitucional posterior que ha llegado hasta nuestros días.

Existen además dos casos particulares de organización recogidas en la normativa que estamos analizando y que quiero destacar:

○ Uno el previsto en el art. 438 respecto a que los Peñones podrán ser constituidos en entidades locales menores adscritas a alguno de los Ayuntamientos de Ceuta y Melilla y en tal caso podrá confiarse la autoridad local a la autoridad interventora más próxima del protectorado.

○ Otro el previsto en el art. 411 que recoge que las juntas vecinales existentes en la provincia de Álava tendrán la competencia que recoge el art. 107 de la ley pero que conservarán sus atribuciones peculiares y se organizarán según sus costumbres tradicionales, sin que puedan ser inspeccionadas por los ayuntamientos, a menos que lo pida la mayoría de sus vocales o la tercera parte de los vecinos que integren la citada entidad local. 


\subsection{5.- Limitaciones a la creación de las entidades locales menores}

Podemos clasificar en tres los tipos de límites a la creación de estas entidades del análisis de la normativa histórica:

- De carácter personal: en las regulaciones anteriores venían estas entidades casi definidas como entidades territoriales, asignándoles los tres elementos característicos de las entidades que comparten tal naturaleza y que son: la población, el territorio y la organización; la población es determinante de la atribución de personalidad jurídica, pues es a ese fin, al de satisfacer a sus habitantes al que nace la ELM. Así lo afirma tajantemente la Real Orden de 13 de julio de 1926, diciendo que para constituir ELM lo deben pedir la mayoría de los vecinos (Sentencia 30 de septiembre de 1927).

○ De carácter territorial: el art. 21 de la Ley de 1935, el art. 26 de la Ley de Régimen Local de 1955 y el art. 48 RP coinciden al afirmar que no podrán constituirse en ELM los pueblos que sean cabeza o capital del término municipal, obsérvese que dice las que se puedan constituir, no las ya existentes o constituidas (Sentencia 26 de mayo de 1961).

- Formal: las limitaciones formales aparecen cuando existen vicios de procedimiento, en el proceso de creación de las ELM. Así lo recoge el Decreto de Presidencia 28 de octubre de 1955 y el Decreto de Gobernación 26 de octubre de 1956.

\section{4.- LA EXTINCIÓN DE LAS ENTIDADES LOCALES MENORES}

Como causas de extinción, en el derecho histórico solo encontramos referencia a este asunto en la Ley Municipal de 1935, que distingue entre:

- extinción voluntaria: establece que es necesaria que sea solicitada dicha extinción mediante petición escrita de la mayoría de los electores y la ratificación del Ayuntamiento respectivo. Si este se opone, resuelve el Consejo de Ministros. ${ }^{63}$

\footnotetext{
${ }^{63}$ Para la disolución de una entidad local menor bastarán la petición escrita de la mayoría de los electores residentes en su término y el subsiguiente acuerdo del Ayuntamiento respectivo. Cuando éste se opusiere a la disolución resolverá el Consejo de Ministros con audiencia del Consejo de Estado.
} 
- extinción forzosa: puede imponerla el Ministro de la Gobernación, si se dan las causas previstas de intervención ${ }^{64}$.

En la Ley de 1955 se reconoce la facultad al Estado de decretar la disolución de los Ayuntamientos y/o Diputaciones así como también de las Juntas Vecinales cuya gestión fuera dañosa o perjudicial para los intereses del Estado o a las propias entidades locales, previa audiencia de las administraciones intervenidas. Si causaran perjuicio en la esfera de los particulares no se les podrá intervenir hasta que se subsane el daño causado $^{65}$. Se podrá nombrar, por parte del Ministerio de la Gobernación, una Comisión Gestora cuyo número de vocales no excederá del de miembros que legalmente integren la Corporación, para que reemplace a ésta en la administración de la correspondiente Entidad hasta que se tomen posesión de sus cargos Concejales o Diputados provinciales nuevamente elegidos (art. 404.1). Si en el presupuesto de la entidad local menor se produjeran varios déficits también se puede decretar su suspensión, por presumir la incapacidad para la rehabilitación de su hacienda (art. 427 Ley). Encontramos aquí el antecedente más inmediato y quizás el genuino a la regulación actual de la disolución de las ELM ante la falta de rendición de cuentas que veremos en el capítulo III.

En cuanto a su modificación y disolución, ambas pueden llevarse a cabo de manera voluntaria o bien por acuerdo del Consejo de Ministros. Como motivos de disolución el art. 28 de la Ley señala que deberán comprobarse:

- la carencia de recursos suficientes para sostener los servicios mínimos de policía urbana y rural;

○ que se aprecien motivos notorios de necesidad económica o administrativa.

\footnotetext{
${ }^{64}$ El expediente de intervención gubernativa habrá de fundarse en alguno de estos motivos:

- Abandono de funciones o incumplimiento reiterado de servicios delegados de la Administración Central.

- Las mismas faltas concernientes al ejercicio de atribuciones o funcionamiento de servicios propios de la competencia municipal y provincial.

- Apreciación conjunta de ambos aspectos.

- Cualesquiera otros relativos a la gestión administrativa en general.

${ }^{65}$ Cuando la culpa o negligencia imputable a los órganos de gobierno de las entidades locales menores derivara de perjuicios o daños irrogados al derecho de los particulares, no será aplicable el régimen de intervención del estado hasta que se hubiere sustanciado la responsabilidad exigible con arreglo a la Ley y a este Reglamento.
} 
Por último, indicar que en cuanto al destino de los bienes en caso de extinción, la situación sería que extinguida una ELM sus bienes pasaran a ser del municipio, a no ser que sean bienes comunales, en cuyo caso seguirán disfrutándolo quienes lo hacían antes (Sentencia 12 de febrero de 1959) ${ }^{66}$.

\section{5.- LOS FINES Y COMPETENCIAS DE LAS ENTIDADES LOCALES MENORES}

\section{1.- Importancia y asignación de los fines de las entidades locales menores}

Como afirma TORRES CURDI, son previamente los bienes y no los habitantes los que delimitan los fines de las ELM. Pero si para el cumplimiento de unos fines es necesaria la disposición de medios personales, reales y formales, parece lógico afirmar que lo que prima es la subordinación de fines a medios disponibles, como suele pasar con el resto de entes públicos territoriales. La existencia y reconocimiento de estas instituciones implica el reconocimiento así mismo de personalidad a las mismas, y ésta última la aplicación de un determinado ordenamiento jurídico dentro del cual se indicarán los fines a cumplir por las ELM.

En el Derecho histórico destacamos los siguientes fines como los más representativos de su razón de ser: en la Ley de 1877 se asigna a las entidades locales menores, o como los llama a los "pueblos agregados," los fines de conservar la administración de sus bienes ${ }^{67}$. En el Estatuto Municipal de 1924 apenas se esboza

\footnotetext{
${ }^{66}$ Esta Sentencia de 12 de febrero de 1959 establece que en el caso de disolución de una ELM pueden seguir aprovechándose de los bienes los habitantes que constituirán el núcleo urbano de la entidad disuelta, esto es el reconocimiento de aprovechamiento a unidad de población sin personalidad (Sentencia de 3 de abril de 1970) pues distingue la jurisprudencia entre titularidad y aprovechamiento, fundamentándolo también en el art. 4 y 11 de la Ley de Montes la cual manda que se determine el Catálogo a aquellos que sean beneficiarios, y además es un derecho intransferible a los descendientes (Sentencia de 4 de octubre de 1960). La Sentencia de 31 de mayo de 1954 reconoce derechos adquiridos a los vecinos anteriormente a la ordenanza y pretenden evitar el avecinamiento en el pueblo de personas que sin vinculo alguno con el por la naturaleza de sus ascendientes, se empadronen atraídos por el disfrute del respectivo lote de pinos. Relacionado con este tema está el de no retroactividad de las Ordenanzas reguladoras (Sentencia de 29 de mayo de 1958).
}

${ }^{67}$ Art. 90: Los pueblos que, formando con otro término municipal, tengan territorio propio, aguas, pastos, montes o cualesquiera derechos que les sean peculiares, conservarán sobre ellos su administración particular. 
cuáles son los fines de las ELM. Reconoce la facultad de inspección de los municipios sobre la administración privativa de las ELM, pero no parece que esta facultad llegara a revocar ni a suspender los acuerdos de las ELM. La Ley de 1935 sigue con la declaración genérica de que disponen de la administración especial para sus derechos e intereses. En la Ley de 1955 se establece una primera referencia global: se reconoce la capacidad jurídica de las ELM para enajenar, gravar, permutar, reivindicar, permutar, gravar o enajenar toda clase de bienes, celebrar contratos, establecer y explotar obras y servicios públicos, obligarse, interponer los recursos establecidos y ejercitar las acciones previstas en las Leyes, dentro de su ámbito específico. Asimismo en el art. 672 de dicho texto legal se muestran los fines en materia económica muy similares a los municipales: la gestión económica de las entidades locales menores tendrá por objeto la administración de sus bienes, rentas, exacciones, derechos y acciones que les pertenecen, con cuya finalidad y sin perjuicio de la intervención del Estado, cuando proceda, les corresponden las funciones siguientes:

○ La formación, aprobación, ejecución y liquidación de sus presupuestos.

- La administración y aprovechamiento de su patrimonio.

- La imposición y ordenación de los recursos autorizados por ley.

○ El reconocimiento y la liquidación, investigación y cobranza, de los derechos, rentas y exacciones.

○ La sanción de infracciones y defraudación.

○ El reconocimiento, liquidación y pago de obligaciones.

- La acción ante tribunales en defensa de los derechos e intereses de sus haciendas.

○ La formación y aprobación de cartas económicas municipales.

○ El ejercicio de derechos, adaptación de medidas e implantación y organización de servicios para el cumplimiento de las funciones económico administrativas que la ley es asigna.

\section{2.- Capacidad y competencia}

Será en el Estatuto Municipal, como hemos visto, donde se ocupa por primera vez de las ELM y donde se les atribuye ya capacidad plena para realizar contratos, actos 
y ejercer acciones, capacidad que novedosamente iguala a la que se atribuye a los Ayuntamientos (art. 4, el cual es muy parecido a la regulación de la LRBRL), salvo las relativas a inspección que corresponden a los Municipios ${ }^{68}$.

Se les reconoce personalidad propia, la cual la es para aprobar ordenanzas, interponer acciones judiciales de todo género..., conservar el patrimonio comunal con arreglo a lo que dispongan las leyes. Esta norma habla ya, podríamos decir, de tres tipos de competencia:

Organizativa: al decir que los Presidentes de las Juntas Vecinales tendrán a su cargo convocar y presidir las Juntas las Asambleas plenas; dirigir sus deliberaciones, con voto de calidad en caso de empate, ejecutar sus acuerdos, si no hubiera causa legítima para suspenderlos

Administración General: diferenciando entre ELM como tal y Concejo Abierto, previendo que las ELM regirán la administración de las mismas, con arreglo al presupuesto aprobado y a los acuerdos de las Juntas y en su caso, del vecindario, rindiendo anualmente las cuentas relativas a su gestión.

Por delegación: refiriéndose al mantenimiento del orden público en el territorio de la jurisdicción, coadyuvando a los Alcaldes Presidentes de los Ayuntamientos, al ser un representante de éste último, permitiéndosele imponer multas de cinco pesetas.

La Ley de 1935 reproduce el art. 4 visto del EM, al afirmar que las ELM tendrán plena capacidad jurídica dentro de los límites y con los requisitos establecidos en las leyes. Les asigna las mismas funciones que a los Alcaldes y a la propia Junta Vecinal las mismas disposiciones que para constitución, gobierno, administración y funcionamiento de los Ayuntamientos se prevé en la ley. Pero se establece una excepción importantísima y que es esclarecedora del peculiar régimen de las JV que viene protegido en esta norma, ya que no se podrá aplicar la ley cuando ésta se oponga a la tradición, uso o costumbre de la Entidad en materia de gobierno, constitución,

\footnotetext{
${ }^{68}$ Art. 101: En los municipios que tengan su población diseminada en parroquias o entidades locales análogas, los Alcaldes delegarán en un concejal, vecino, a ser posibles, de cada parroquia, las atribuciones de inspección que les correspondan sobre los servicios de policía judicial y rural, vigilancia, guardería forestal, distribución de aprovechamientos comunales, y demás que interesen a la Municipalidad, sin detrimento de las funciones propias de la Junta Vecinal.
} 
administración y funcionamiento ${ }^{69}$. Pareciera ser que la aplicación libre de la ley no es del todo completa y posible, incluso si no existiera tradición, uso o costumbre, tal y como señala el artículo citado, si la actuación pudiera entrar en conflicto con su particular ordenamiento, la consecuencia pudiera derivar en la invalidez del acto.

La Ley de Régimen Local 1955 recoge, como hemos visto, en su art. 107, mediante una enunciación de atribuciones, no de carácter exclusivo, si no puramente enunciativo, las competencias de las entidades locales menores ya vistas. Distinguiremos ya las competencias asignadas al Presidente por un lado y por otro a la Junta Vecinal:

- Presidente: recoge que el gobierno y administración del municipio estarán a cargo del Alcalde y del Ayuntamiento, uno y otro con atribuciones propias. Y que los intereses peculiares de las ELM serán administrados por el Alcalde Pedáneo y la Junta Vecinal. Así las atribuciones del Alcalde Pedáneo, que serán las mismas del Alcalde pero limitadas a su término, vigilar la conservación de caminos rurales fuentes públicas y montes, así como los servicios de policía urbana y de subsistencias. Auxiliar al Alcalde en el mantenimiento del orden público ${ }^{70}$. Por último y como competencia residual, se reconoce al Alcalde Pedáneo, todas las demás facultades de gobierno y administración de la ELM no reservadas expresamente a la Junta o Asamblea vecinal por la ley.

○ Junta Vecinal: con relación al gobierno y administración de la ELM, serían las siguientes competencias:

- La aprobación de presupuestos y ordenanzas de exacciones, la censura de cuentas y el reconocimiento de crédito.

- La administración y conservación de los bienes y derechos propios de la entidad y la regulación del aprovechamiento de los bienes comunales.

\footnotetext{
${ }^{69}$ Art. 69: Los Presidentes de las Juntas Administrativas de las Entidades Locales menores tendrán las mismas facultades que los Alcaldes en cuanto se relacione con la administración y gobierno de la entidad, serán aplicables a las Juntas las disposiciones reguladoras de la constitución, gobiernos, administración y funcionamiento, de los Ayuntamientos, que se contiene en esta Ley, en todo aquello que no sea específico de estos ni es oponga a lo que establezca el uso, la costumbre o la tradición con respecto a la entidad.

${ }^{70}$ TORRES CURDI, op cit pág. 145: “Al actuar el Alcalde como delegado del Gobernador Civil, no podrá, a su vez, delegar en el Presidente de la Junta, que será un mero auxiliar en el mantenimiento del orden público, a no ser que por el Gobernador Civil se efectúe la delegación correspondiente.
} 
- El ejercicio de acciones judiciales y administrativas y, en general, cuantas atribuciones se asignen en esta ley al Ayuntamiento con respecto a la administración del municipio.

En cuanto a la disposición de bienes, hay una intervención del Ayuntamiento, al preverse que tanto en la disposición propiamente dicha, para las operaciones de crédito y para la expropiación forzosa los acuerdos deberán ser ratificados por el Ayuntamiento respectivo.

\section{3.- Concurrencia de fines}

Uno de los problemas más patentes en la convivencia entre ELM y el Ayuntamiento es la relativa a la concurrencia de fines. A lo largo de la historia del municipalismo español recogemos la siguiente evolución en su regulación: el Estatuto Municipal de 1924 señalaba que las ELM que excedan de 1.000 habitantes y en especial las que formen barriadas o anexos urbanos agregados a grandes poblaciones, podrán regir sus intereses privativos por medio de una Junta Vecinal, la cual actuará en la forma establecida para el Ayuntamiento pleno. Cada ayuntamiento podrá determinar, sin embargo, dentro de esta norma genérica, la organización y funciones de las Juntas. La expresión "podrá" determina el carácter de opcional. La concurrencia de fines determina, a veces, una identidad de organización entre el municipio y la ELM, como hemos visto en este art. 109, pero con dos características derivadas del propio artículo: solo podrán tenerla las ELM que excedan de 1000 habitantes, y supone una intervención en el régimen de bienes. El art. 150.28 señalaba esta importante directriz, y es que era de la exclusiva competencia de los Ayuntamientos, subordinada tan solo a la observancia de las Leyes Generales del Reino y a lo que esta Ley dispone, el gobierno y la dirección de los intereses peculiares de los pueblos en la totalidad su territorio, y en particular cuando guarde relación con los objetos siguientes:

1) La inspección sobre la administración privativa de las Entidades Locales Menores;

2) El art. 159 recoge que las Juntas Vecinales y Parroquiales ordenarán el aprovechamiento y disfrute de los bienes comunales de los pueblos con arreglo a unas disposiciones, y entre ellas que la legitimación de roturaciones arbitrarias 
hechas en terrenos comunales, a que hace referencia el Real Decreto de $1^{\mathrm{o}}$ de diciembre de 1923, solo podrá otorgarse a los vecinos del pueblo;

3) Por su parte, el art. 101 al hablar de las atribuciones de inspección de los Alcaldes sobre ciertos servicios a cumplir por las ELM implica una concurrencia de fines, si bien se prevé que sea "sin detrimento de las funciones propias de la Junta Vecinal”.

Más adelante y ya teniendo presente la Ley de 1935, al reproducir ésta el art. 4 del EM reconoce a ambas instituciones, municipios y ELM capacidad jurídica plena que implica una concurrencia de fines de manera implícita. En un momento posterior, la Ley de 1955 al hablar de competencia residual en lo referente a obras y prestación de servicios, referido a cuando no lo tenga a su cargo el respectivo municipio, está reconociendo esa concurrencia de fines de ambas entidades. 


\section{6.- REGULACIÓN DEL RÉGIMEN DE LOS BIENES DE LAS ENTIDADES LOCALES MENORES EN EL DERECHO HISTÓRICO}

Hemos visto a lo largo de este trabajo que uno de los motivos fundamentales que justifican la existencia de este tipo de entidades es la gestión y administración de unos bienes peculiares que les son propios. A lo largo de la evolución histórica, analizamos el tratamiento que han recibido en la normativa la regulación de los bienes de las entidades locales menores.

\section{1.- Derecho histórico}

En la Ley de 1877 no se prevé expresamente la titularidad de bienes a favor de las ELM pero se considera un derecho de los pueblos y además, dice el art. 90: "que tengan pastos, montes..." y se acepta la costumbre que sobre el aprovechamiento sobre ellos existiera. El régimen de bienes, si bien el titular en el caso que nos ocupa es una persona jurídica pública, puede estar sometido en algunos aspectos al derecho privado. Por su parte, el Estatuto Municipal de 1924 reconoce ya de una manera expresa que las ELM son un conjunto de personas y bienes, y además se les reconoce la capacidad de adquirir, gravar enajenar etc... bienes y se declaran derogadas las leyes desamortizadoras. Un primer problema que encontramos es que en el art. 310 cuando habla del patrimonio municipal incluye también el de las ELM, el común de los vecinos, así que no podemos dejar de hacernos esta pregunta, ¿qué bienes debemos entender que son los de las entidades locales menores?, en mi opinión entiendo que cualquiera que sea el titular de los indicados, formará el patrimonio de la entidad local menor. Asimismo cuando en su art. 4 reconoce "capacidad plena" a las ELM también les está reconociendo una capacidad privada siempre que la naturaleza de la relación así lo permita. Me gustaría destacar también como significante que en este texto legal al recoger los diferentes recursos que se pueden interponer vimos en su art. 265 que caben recursos en materia civil si se lesionan derechos de esta naturaleza sobre tal materia. Por otro lado el Reglamento de Población del momento hace referencia a los bienes como determinantes de la personalidad de dichas entidades, y a mayor abundamiento, el 
Reglamento de Hacienda de 1924 al hablar de los recursos de las ELM se refiere a la posibilidad de establecerse por relación hereditaria, lo cual nos lleva ante otro caso de capacidad privada, asimismo recoge la obligación de catalogación de todos los bienes de las ELM sin distinción de su naturaleza.

En la Ley de 1935 al definir a las ELM y al reconocerle el derecho a la administración de sus peculiares derechos e intereses colectivos, está reconociendo a los bienes como un elemento determinante de dichas entidades, junto con el territorio y la población. En el art. 2.2 se reconoce la capacidad para adquirir, enajenar, reivindicar, conservar bienes de todas clases, así que también se reconoce la existencia de un ámbito de derecho privado en esta materia, al atribuirles la posibilidad de celebración de contratos privados.

La posibilidad de ser titulares de bienes les viene expresamente reconocida al atribuirles "plena capacidad jurídica" ${ }^{71 "}$ en la Ley de 1955. El art. 25.1 señala que: "Una vez constituida la ELM se establecerán los límites territoriales de la jurisdicción respectiva y se hará la separación patrimonial correspondiente”. En esta ley al igual que en la Ley de 1935, se reconoce la capacidad de las ELM de adquirir, gravar, reivindicar, enajenar toda clase de bienes reconociendo la posibilidad de realización de contratos privados. En el Reglamento de Población se recoge en el art. 47.3, el término

\footnotetext{
${ }^{71}$ También son varios los ejemplos que en la jurisprudencia nos podemos encontrar en cuanto al reconocimiento de la propiedad de bienes a favor de las ELM. Destacamos la Sentencia de 22 de noviembre de 1955 la cual reconoce el derecho al aprovechamiento de los bienes de las ELM, donde se analiza la existencia y personalidad de la ELM de Sirenuela y el reconocimiento del derecho de propiedad del monte y sus aprovechamientos, que en este caso se pretendían rescatar. También la sentencia de 2 de mayo de 1961 afirma la existencia y titularidad de los bienes comunales a favor de una ELM, así como la Sentencia de 15 de noviembre de 1962 que admite la posibilidad de inmatriculación registral de bienes de las ELM mediante certificación de la propia Junta.

Muy importante me parece la Sentencia de 3 de diciembre de 1956, la cual determina que el aprovechamiento de los bienes comunales se realizará mediante explotación colectiva y si la misma no fuera posible, a falta de costumbre o reglamentación local, se realizará por lotes o suertes a los vecinos cabezas de familia en relación directa al numero de familiares e inversa a su situación económica, llevándose en este caso y según costumbre, el reparto por "lares" o "fuegos" o sea, por casas, por ser más conveniente que la explotación común, costumbre aceptada de reparto de un monte comunal, de lo cual se advierte la importancia que en materia de bienes se otorga a la costumbre, y la afirmación de esta sentencia que casi reproduce el régimen de aprovechamiento de los bienes comunales recogido en el Reglamento de Bienes actual.

También encontramos diversos ejemplos en la jurisprudencia de diversidad de situaciones en cuanto al reconocimiento y gestión de los bienes, así la Sentencia de 27 de abril de 1963 declara que si no existe personalidad no puede existir titularidad, pero sí aprovechamiento, ya que en ese caso si bien la titularidad era del Ayuntamiento en cuestión, eran beneficiarios de esos bienes los vecinos del anejo no reconocido como ELM. Otro ejemplo de la jurisprudencia de la época, que reconoce la posibilidad de posesión material y administrativa a las ELM, es la Sentencia de 15 de octubre de 1963.
} 
jurisdiccional de las ELM, referido a su territorio y demás terrenos que constituyan su patrimonio. Y en el Reglamento de Haciendas, en su art. 2, expresamente se reconoce la posibilidad de pertenencia de bienes a estas entidades reconociendo la posibilidad de titularidad de bienes privativos.

\section{2.- Clases de Bienes}

\subsection{1.- Bienes de Propios}

La Ley de 1877 y el EM de 1924 no realizan clasificación alguna, en el primer texto legal solo se hace referencia en el art. 90 tanto a los bienes como a los derechos, y en el segundo en el art. 310 habla que los bienes pueden pertenecer tanto a la entidad, como al común de los vecinos e incluso a establecimientos de la ELM. Más adelante, en la Ley de 1935, ya se procede a clasificar los bienes de los ayuntamientos, y a su vez, en el art. 147 de la misma, se distingue entre bienes de uso público y patrimonial, y éstos en propios y comunales. Define los bienes de uso público mediante remisión al art. 344 del CC, señalando que los restantes serán de naturaleza patrimonial, siendo comunales cuando se desfruten de manera gratuita y exclusivamente por los vecinos, y los de propios cuando se destinen directamente a satisfacer necesidades del Municipio o a la realización de servicios municipales. También recoge este texto normativo la obligación de formar Inventario ${ }^{72}$, y también determina la obligación de proceder a su rectificación anual y además cuando se proceda a renovar la Corporación deberá ser revisado también el Inventario, debiendo remitir copia del mismo y de sus rectificaciones a la Sección Provincial de Administración Local, para su custodia y fines estadísticos.

En el art. 202 de la Ley de 1955 se prevé que todo lo recogido sobre el régimen de bienes municipales se aplicará también al régimen de bienes de las ELM. Dicho lo cual la ley comienza definiendo los bienes de propios en su art. 186, como aquellos que siendo de propiedad del municipio no estén destinados al uso público ni a la realización de ningún servicio, y puedan constituir fuente de ingreso para el erario municipal. En el

\footnotetext{
${ }^{72}$ Se prevé la exclusión del inventario de aquellos bienes pertenecientes a establecimientos e instituciones cuyo patronato corresponda al municipio, elaborando una relación valorada de los mismos que se conservará unida a dicho inventario.
} 
art. 189 se regulan los requisitos exigidos para poder proceder a la transmisión de estos bienes, estableciendo un control estatal para la enajenación de los mismos, así dicho artículo señala que los bienes inmuebles de propios no podrán enajenarse ni gravarse sin autorización del Ministerio de Gobernación, previo informe del Ministerio de Hacienda, cuando su valor exceda del $25 \%$ del Presupuesto anual de la Corporación. Y se prevé la dación de cuentas de toda enajenación de bienes inmuebles que se lleve a cabo, control que ha pervivido hasta la actual regulación. Respecto de las cesiones gratuitas también se establecen límites, exigiendo que las mismas sólo se puedan hacer cuando los destinatarios sean entidades o instituciones públicas para fines que redunden en beneficio de los habitantes del término municipal y previa autorización del Ministerio de Gobernación. Por último, señalar como destacable que el art. 199 recoge ya la obligación de inscribir los bienes inmuebles y derechos reales en el Registro de la Propiedad, ya sea mediante escritura pública, autorizada por Notario, o bien mediante certificación del Secretario de la Corporación, con relación al inventario aprobado en la misma. Para completar la regulación que efectúa la Ley de 1955 debemos también hacer referencia a que expresamente el Reglamento de Bienes de 1955, nos establece la clasificación de los bienes de las ELM. En su art. 2 señala que los bienes de las ELM se clasifican en bienes de dominio público y bienes patrimoniales, y respecto a éstos el art. 5 los subclasifica en propios y comunales.

\subsection{2.- Bienes Comunales}

Este tipo de bienes de naturaleza comunal y existencia casi histórica, se venían definiendo como aquellos cuyo aprovechamiento y disfrute pertenece exclusivamente a los vecinos. Y dentro de ellos podríamos distinguir entre los bienes comunales en sí, y los bienes en mano común ${ }^{73}$. El art. 187 de la Ley 1955 los define como los de dominio

\footnotetext{
${ }^{73}$ En la jurisprudencia, la distinción entre bienes comunales y bienes en mano común no se aprecia en cuanto al aprovechamiento, aunque la titularidad es distinta. Refiriéndonos a los bienes comunales podemos distinguir la regulación del aprovechamiento del derecho en sí que tienen los vecinos para tomar parte en él.

En los bienes comunales la titularidad corresponde a la entidad local, así como su explotación y su aprovechamiento al común de los vecinos; en los bienes en mano común la titularidad y el aprovechamiento confluyen en los mismos sujetos, siendo estos los vecinos de la propia entidad, aunque para tener acceso al aprovechamiento haga falta una serie de requisitos, regulados por Ordenanzas y a falta de las mismas por la costumbre local.

La regulación del aprovechamiento es competencia exclusiva de la Asamblea Vecinal (Sentencia 19 de octubre de 1957). Dicho aprovechamiento tiene que estar regulado por Ordenanzas, y en defecto de las mismas aplicar la costumbre local (art. 192 Ley 1955 y Sentencia 3 de diciembre de 1956: esta sentencia
} 
municipal cuyo aprovechamiento y disfrute pertenece exclusivamente a los vecinos. La Ley de Partidas ya contenía en la Ley IX y la Ley X definición de los bienes comunales y los de propios respectivamente:

○ Los comunales "de quales cosas pertenece el señorío et el uso de las comunalmente a todos los homes de alguna ciudat o villa".

○ Los de propios: cuales cosas pertenecen a alguna cibdat o villa o común, et non puede cada uno dellos apartadamente usar de ninguna dellas.

Como competencia de las Juntas Vecinales se establece en el EM de 1924 la ordenación del aprovechamiento de los bienes comunales, concretamente en su art. 159, pero con arreglo a las bases que fije la Asamblea Vecinal. El Reglamento Hacienda Municipal de 1924, si bien no recoge expresamente el concepto de bien comunal, si que se refiere a los bienes y derechos que pertenezcan al común de los vecinos, en su art. 21.

Por otra parte, la Ley de 1955 en su art. 107 dentro de las competencias ${ }^{74}$ asignadas a las ELM incluye la de regulación del aprovechamiento de sus bienes comunales. Parece que al decir la expresión "sus bienes comunales" da a entender que son de su titularidad. Pero luego al referirse a la Junta Vecinal o a la Asamblea Vecinal habla de la regulación del aprovechamiento de bienes comunales, pareciendo que el aprovechamiento, sea de quien sea la titularidad, debe decidirse el régimen de aprovechamiento por la mayoría de los comuneros.

reconoce la posibilidad de explotación de dichos bienes mediante reparto por "lares" o "fuegos", o sea, por casas, por ser más conveniente que la explotación colectiva y siendo esa costumbre local probada).

Destaca también la Sentencia de 11 de mayo de 1968 que declara los derechos del viudo o viuda que vuelva a contraer matrimonio con quien no tiene derecho.

Y también es importante la Sentencia de 05 de febrero de 1970 que manifiesta que en caso de no recogerse requisitos especiales para determinar las condiciones que deben ostentar los vecinos, será determinante el hecho de estar empadronado en el Padrón de Habitantes, pues daría derecho al aprovechamiento.

El disfrute es general a todos los vecinos y deberá ser según las condiciones recogidas en las ordenanzas, no pudiendo ser objeto de discriminación para los vecinos si éstos reúnen las condiciones exigidas y tienen la condición de vecino con anterioridad a la aprobación de la Ordenanza (Sentencia 3 de octubre de 1958).

\footnotetext{
${ }^{74}$ MARTINEZ DIAZ, A. "Régimen económico de las entidades locales menores". Revista de estudios locales y autonómicos, $n^{\circ} 80$. 1955. pág. 222 "el vigor tradicional y la perpetuación a lo largo de las fases legislativas de las ELM se debe al sólido patrimonio que han podido conservar y aplicar a sus peculiares necesidades. Las discordias en torno a la creación o supresión de grupos diferenciados han surgido en su mayoría con motivo del aprovechamiento de un monte o del disfrute de bienes comunales".
} 


\section{3.- Régimen jurídico de los bienes}

A la hora de regular el régimen jurídico de los bienes, destaco el previsto para los bienes comunales en el EM de 1924. En esta norma se señala que tanto la Comisión municipal permanente, ajustándose a las reglas dictadas por el Ayuntamiento pleno, como las Juntas Vecinales y parroquiales, ordenarán el aprovechamiento y disfrute de los bienes comunales de los pueblos con arreglo a las disposiciones siguientes (aquí encontramos también los antecedentes más directos con la actual regulación del régimen de explotación de los bienes comunales de hoy en día recogida en el Reglamento de Bienes de 1986 y que veremos en el capítulo V):

1.- Mientras sea practicable este modo de disfrute, continuarán los aprovechamientos gratuitos por el común de los vecinos, y únicamente se enajenarán por precio los esquilmos y productos cuya utilización comunal no resulte posible.

2.- Cuando los aprovechamientos sean gratuitos, la distribución se hará entre los vecinos, adjudicando a cada uno la parte que le corresponda en proporción al número de personas que estén a su cargo o vivan en su casa.

3.- Cuando los bienes comunales no se presten a ser utilizados por los vecinos, en la forma antedicha, se adjudicará el disfrute y aprovechamiento mediante precio, en pública subasta, dándose preferencia a los vecinos sobre los forasteros, en igualdad de condiciones.

4.- Sólo en caso extraordinario podrá el Ayuntamiento, previo acuerdo de las dos terceras partes de los concejales que lo constituyan, fijar una cuota que deberá abonar los vecinos, sobre los lotes adjudicados de bienes comunales.

La legitimación de roturaciones arbitrales hechas en terrenos comunales, referenciados en el Real Decreto de 1 de diciembre de 1923, sólo podrá otorgarse a los vecinos del pueblo.

El art. 160 afirma que no serán reputadas como enajenación ni gravamen, las concesiones de parcela de terreno del patrimonio municipal, a favor de vecinos braceros, cuando el disfrute a éste otorgado haya de durar menos de diez años. Estas concesiones y las que se otorguen a vecinos del municipio para plantar arbolado en terrenos del patrimonio concejil, no catalogados como de utilidad pública, han de ser acordados por el Ayuntamiento pleno, o en aplicación que haga la comisión municipal 
permanente de las reglas establecidas a los efectos por aquél. Los vecinos que hayan obtenido permiso para plantaciones y lo utilicen con arreglo a las condiciones establecidas, se harán dueños de los árboles que cultiven $\mathrm{y}$, durante los cinco primeros años podrán acotar las parcelas plantadas a fin de preservarlas de los ganados. Cuando la acotación de parcelas con este fin perjudique los aprovechamientos comunales, las concesiones quedarán en suspenso por virtud de reclamación de los vecinos, hasta que sobre ella recaiga acuerdo del Ayuntamiento pleno. En la Ley de 1955 se determina que el régimen para los bienes de las ELM será el mismo que para todas las EELL. 


\section{7.- CONSIDERACIONES}

De todo lo expuesto podemos concluir que:

- Nos hallamos ante una entidad que responde al origen natural del hombre mismo, y que es una realidad la máxima que afirma que donde hay población hay aldea, pero ha sido una entidad tardía en su regulación e integración en el ordenamiento jurídico. Como si, pese a su antigüedad en el tiempo, a nadie le hubiera interesado regular o profundizar en lo que naturalmente venía funcionando como algo intrínseco al ser mismo.

- Estas entidades apenas han sido objeto de una regulación mediana, ya no digo extensa, por parte del legislador, pese a su alto grado de interiorización social.

- El problema de la coincidencia de la existencia de una entidad local menor en el mismo núcleo de población donde reside el municipio no se ha regulado de manera tajante en los antecedentes normativos, y en la actualidad son muchos los casos en los que se superponen ambas figuras, no habiéndose hecho nada por corregirlo. Por tradición venían siendo compatibles e incluso existían supuestos de división del término en micromunicipios independientes entre sí, pero aglutinados por la presencia del Ayuntamiento superpuesto, compartiendo presencia física sin interferencias en los cometidos de cada entidad, pero en la actualidad y dentro del espíritu de racionalización que se predica de las administraciones públicas no tiene sentido esta situación, la cual, insisto, da lugar a numeroso conflictos competenciales.

○ Uno de los puntos que he detectado en el estudio del origen y evolución histórica de estas entidades es el referido a su disolución, y de cómo ya en el año 1959 se estableció por la jurisprudencia de la época que en tal caso los bienes de la entidad suprimida pasarían a formar parte del patrimonio del municipio al que pertenecieran, salvo que dichos bienes fueran comunales, en cuyo caso podrían seguir disfrutándolo quienes lo hacían antes. Esta premisa es muy importante de cara a la situación que vivimos en la actualidad ante la amenaza de desaparición de las ELM puesto que su valor más preciado es precisamente este, la gestión 
patrimonial, y si por esta vía se pudiera garantizar que pese a la supresión de la ELM los bienes van a poder seguir siendo disfrutados por las personas que quedan en el núcleo suprimido como ELM eliminaría muchas suspicacias.

- Que con relación a la titularidad por parte de estas entidades de bienes comunales, en muchos casos en abundancia y que generan mayores ingresos que los que perciben los municipios, se ha observado a lo largo del análisis de esta evolución que los municipios se han visto obligados a mantener unos servicios esenciales y mínimos por su propia condición de ayuntamiento y a luchar con los egoísmos e inclinaciones disgregadoras de unos núcleos que no sienten en varias ocasiones impulsos de solidaridad para contribuir de manera equitativa al sostenimiento de las cargas generales del municipio. Viniendo a ser la posible solución a dicha situación, la cual ha llegado a nuestros días, una racional ordenación del régimen económico de las ELM. 


\section{REGULACIÓN ACTUAL DE LAS ENTIDADES LOCALES MENORES EN \\ EL MARCO ESTATAL Y AUTONÓMICO.}

\section{1.- MARCO JURIDICO ESTATAL DE LAS ENTIDADES LOCALES MENORES}

\section{1.- Regulación estatal}

Después de haber visto la evolución histórica en el origen y regulación de la normativa de las ELM, nos situamos ya en la época constitucional actual. Si bien la Constitución Española de 1978 no recoge de manera expresa a éstas entidades, sí parece implícitamente transmitir que la existencia de las mismas, o la llamada “descentralización municipal”, como podemos entenderla, está plenamente respaldada ${ }^{75}$.

Las ELM son auténticas entidades locales que encuentran su fundamento en asumir competencias mediante la descentralización del ejercicio de las mismas, si bien dichas entidades, distintas de los municipios, están en un plano inferior a éstos, del que dependen en sentido material y jurídico, ya que, aunque dotadas de personalidad jurídica, no dejan de formar parte del mismo ${ }^{76}$.

Hasta hace poco estas entidades venían reguladas en los artículos 3.2, 45 y 47.2b) de la LRBRL, así como en los art. 38 a $45 \mathrm{TRRL}^{77}$. Diferenciándose de las

\footnotetext{
75 TOLIVAR ALAS, L. "Las entidades inframunicipales" pág. 376, en "La Reforma del régimen local" Tiran Lo Blanch 2014.

${ }^{76}$ CORRAL GARCÍA, E. "Las entidades locales menores. Sus orígenes, desarrollo y competencias". $E l$ consultor de los Ayuntamientos y juzgados $n^{\circ}$ 19. 2003. Pág. 3261: El desconocimiento cuando no el desprecio, de la realidad social suponen una cortina de humo que impide arrojar luz sobre el trasfondo del hecho social existente. [...] El hecho es especialmente llamativo en León, Palencia y Burgos. Refiriéndose a la provincia de León, DIEZ GONZALEZ, FA. afirmaba que cada aldea sustenta un ente concejil.

${ }^{77}$ TOLIVAR ALAS, L. op cit. “La descentralización ...”, Pág. 119: “en la Ley 7/1985, de 2 de abril, en su artículo 3 incluye entre las entidades locales no territoriales a las de ámbito inferior al municipal [...], como puede apreciarse, desaparece la denominación de entidades locales menores, por respeto a las competencias de las Comunidades, algunas de las cuales, como Galicia o Asturias, ya habían visto plasmadas en sus Estatutos de Autonomía, referencias expresas a denominaciones tradicionales".
} 
entidades locales territoriales ${ }^{78}$, que son el municipio, la provincia y la isla, en la LRBRL se les da, por primera vez, el nombre de entidades de ámbito territorial inferior al municipio (anteriormente eran llamadas entidades locales menores, que, siguiendo la expresión de PONS BRUNET, “implica la necesidad de ponerla en relación, de compararla, con otra entidad mayor de su mismo orden" ${ }^{79}$. Por lo tanto, y atendiendo a dicha regulación, estas entidades no tienen configuración de territoriales (aunque por vía de la atribución ${ }^{80}$ que les pueda hacer la legislación autonómica sí que podrían) y, como veremos, tampoco tienen atribuido un nivel de competencia general, como es el caso previsto para los municipios ${ }^{81}$. La regulación se complementa con la prevista en el RPDT en los artículos 40 a 50 y en el ROF en sus artículos 142 a 145.

\section{2.- El problema de la naturaleza de las entidades locales menores}

La cuestión sobre la naturaleza territorial de estos entes no es una cuestión pacífica ${ }^{82}$.

\footnotetext{
${ }^{78}$ GIRADO CID, C. op cit. pág. 251: “... a nuestro juicio la ELM es un ente local territorial que queda por debajo del nivel del art. 3.1 LRBRL, dado que su estimación en este estrato equivaldría a la incardinación de un municipio en el seno de otro municipio, con los efectos de la segregación de parte de este último para constituir otro distinto".
}

${ }^{79}$ PONS BRUNET, M. "Las entidades locales menores. Consideraciones sobre su existencia y régimen" Revista Estudios Vida Local, $n^{\circ}$ 46. 1949. pág. 551.

${ }^{80}$ Las CCAA podrán dotar de un número de competencias más amplio que el previsto en el art. 38 TRRL y por tanto de más potestades, cfr. SOSA WAGNER, F. "Manual Derecho Local” Aranzadi 2000, Navarra, pág. 73.

${ }^{81}$ PALlARÉS SERRANO, A. Op cit. “Aproximación al régimen...”. Pág. 138: "De acuerdo con el reparto competencial que establece el artículo 149.1.18 CE, lo primero que determina el art. 45 de la LBRL, es que la regulación de las entidades de ámbito territorial inferior al municipio corresponde a las CCAA, y que éstas podrán utilizar para referirse a ellas la denominación tradicional existente en cada Comunidad o cualquier otra que establezca la normativa autonómica. Al respecto, hemos de decir que en la legislación española de régimen local estas entidades se han conocido comúnmente bajo el nombre de entidades locales menores, y que muchas leyes autonómicas han optado por esta denominación. [...] La normativa ha establecido la denominación de "entidades municipales descentralizadas". Con anterioridad, en la Ley 8/1987, Municipal y de Régimen Local de Cataluña, estas entidades se conocían en Cataluña bajo el nombre genérico de entidades locales menores.

${ }^{82}$ FERNANDEZ CRIADO, J. "Régimen actual y futuro de las entidades locales menores". Revista Tierras de León. Diputación de León. Vol. 25, no 60. 1985. pp. 25-36.: “es curiosa esta clasificación como "no territoriales" cuando en el proyecto de la LRBRL sí que se le atribuía esta condición. No sabemos si esto quiere decir que estas entidades van a ser rebajadas de categoría respecto a cómo han estado conceptuadas hasta ahora", cfr. BLASCO DIAZ, JL. "Descentralización, autonomía y entidades de ámbito territorial inferior al municipal”. Revista estudios administrativos locales y autonómicos, $n^{\circ} 312$. 2010. Madrid. Pp. 47-79: "en cualquier caso se trata de entidades y no de meros órganos desconcentrados del municipio en que radican, aunque forman parte de éste, por lo que disponen de personalidad jurídica 
No debemos olvidar que es la LRBRL la que por primera vez introduce esa connotación adjetivista del territorio. Y no son pocas las contradicciones que encontramos en el ROF, donde en su articulado se refiere indistintamente a entidades locales territoriales incluyendo a las ELM. MENENDEZ GARCIA ${ }^{83}$ afirma que la distinción entre entes territoriales y no territoriales se basa en una doble consideración doctrinal: para los que sostienen que el territorio es un elemento esencial, presupuesto de su existencia misma; y para los que mantienen que no es más que la delimitación del ámbito espacial para el ejercicio de sus competencias; para aquellos las ELM nacen para el cumplimiento de una universalidad de fines y para éstos últimos para el cumplimiento de unos fines concretos. Si bien esta distinción ha sido criticada por algún autor, como NIETO $^{84}$ o GARCIA DE ENTERRIA ${ }^{85}$, al afirmar que el territorio no sirve para distinguir dos clases de entes públicos, sea cual sea el valor jurídico del mismo. La connotación de una entidad como territorial sirve para atribuir únicamente a las entidades que la ostentan, de la potestades y privilegios enumerados en el art. 4.1 LRBRL: reglamentaria y de autoorganización, tributaria y financiera, expropiatoria, sancionadora etc..; estando además legitimadas para la impugnación de disposiciones o actos de las Administraciones del Estado o de las Comunidades Autónomas que se entienda lesionan la autonomía local, si bien las potestades les pueden ser atribuidas en virtud de atribución legislativa que efectúe la Comunidad Autónoma al configurarlas ${ }^{86}$.

\footnotetext{
propia y de plena capacidad para el cumplimento de sus fines, y tienen elementos similares a las entidades territoriales, aunque no existe una separación del municipio".

${ }^{83}$ Op. cit. pág. 1205.

84 “Entes territoriales y no territoriales”, RAP, nº 64, 1971, pág. 35.

${ }^{85}$ GARCIA DE ENTERRIA, E./FERNÁNDEZ, T.R. “Curso de Derecho Administrativo”, Vol. I, 2000, pág. 379. Civitas, Madrid.

${ }^{86}$ SOSA WAGNER, F. "Manual de Derecho Local”. pág. 73. Cfr. MENENDEZ GARCIA, P. op cit pág. 1207.
} 


\section{3.- La regulación competencial}

Con relación a las competencias ${ }^{87}$ que les atribuye la normativa estatal, citaremos las previstas, hasta ahora, en el art. 38 TRRL, que son: “a) La construcción, conservación y reparación de fuentes, lavaderos y abrevaderos. b) La policía ${ }^{88}$ de caminos rurales, montes, fuentes y ríos. c) La limpieza de calles. d) La mera administración y conservación de su patrimonio, incluido el forestal, y la regulación del aprovechamiento de sus bienes comunales. e) ${ }^{89}$ La ejecución de obras y la prestación de servicios comprendidos en la competencia municipal y de exclusivo interés de la Entidad, cuando no esté a cargo del respectivo Municipio”. Si bien, hay que puntualizar que la legislación autonómica puede reservarles otras con el mismo carácter.

Siguiendo a MENENDEZ GARCIA, se debe remarcar que los artículos 38 a 45 del TRRL no tienen carácter básico y por lo tanto son supletorios en aquellas CCAA que no tengan competencia legislativa en las materias que en ellos se regulan o la misma no se hubiera ejercido. Por lo tanto, y a diferencia de la regulación establecida en la LRL de 1955, que preveía un régimen jurídico uniforme para estas entidades, nos

\footnotetext{
${ }^{87}$ GIRADO CID, C. op cit. pág. 250: “...de acuerdo con el art. 7.2 LRBRL, las citadas competencias propias, o las que en otro caso puedan establecer con el mismo carácter las CCAA, en principio correspondería ejercerlas a la entidad local menor en régimen de autonomía y bajo se propia responsabilidad, atendiendo siempre

a

la debida coordinación en su programación y ejecución con las demás AAPP. En este caso y de manera especial habrá de hacerlo junto con la Administración de la municipalidad en la que está inserta. Junto a éstas podrá ejercer competencias delegadas, en los términos de la propia delegación.

${ }^{88}$ Las entidades locales menores no pueden por sí mismas crear plazas funcionariales de policía local, ya que son los municipios los habilitados para crear cuerpos de policía local. El TS dice que "no puede decirse que disponer de un propio cuerpo de policía sea un elemento imprescindible para la autonomía que pueda corresponder a una EATIM" (STS 19 de mayo de 2008).
}

${ }^{89}$ MENENDEZ GARCIA, P. op cit, pág. 1203: citando a GARRIDO FALLA, F. cfr en "Las entidades locales menores" Revista española vida local, $n^{\circ} 35$. 1974, afirma que en el apartado e) estamos ante un auténtico sistema de delegación de competencias, o como competencia residual o subsidiaria, citando como referendo jurisprudencial la STS 20 de octubre de 1977, ante un supuesto de falta de competencia de una Junta Vecinal en relación a la posibilidad de conceder licencias de obras, donde el TS estima correcta la posibilidad de que dicha entidad local menor pueda expedir licencias de obras, pero matiza, que puede ejercitarla en la medida que el ayuntamiento no retuvo para sí dicha competencia y cedió, expresamente, la percepción de los ingresos por tasas devengadas por la expedición de las licencias de obras. Cita ese autor la STS de 27 de enero de 1986 sobre competencias urbanísticas de las ELM, y remarca que supuso un "giro copernicano" al considerar dicha sentencia que pasa a ser competencia de la ELM cualquier competencia municipal cuando se circunscriba al territorio de ésta, invocando el art. 125 c) LRL, actualmente el art. 41 TRRL, aspecto bastante novedoso y sorprendente que provocaría que la separación entre entidad inframunicipal y el municipio al que pertenece se hiciera más difuminada. 
podremos encontrar con regímenes competenciales diversos según en qué CA nos encontremos. Así que, y dejando a salvo el respeto al contenido mínimo recogido en el art. $45.2^{90}$ LRBRL, cada CA legislaría el perfil de estas entidades locales.

Ante esta situación hallamos supuestos bien diferenciados, y en los que el acuerdo de creación de cada entidad es el que determina las competencias que ejercerán de las que establezca o recoja la normativa autonómica y en otros casos ya vienen recogidas de forma legal, tal y como sucede en Castilla y León; si bien algunos autores $^{91}$ critican esta forma de regulación competencial al entender que pudiera quebrar la correspondencia con los motivos de la creación de la entidad local, causando una disfunción entre la necesidad de creación misma y el resultado final.

Lo que sí compartimos es la opinión de que no pueden tener una generalidad de funciones, tal y como sucede con los municipios. Ya que ante esa situación chocaría con la finalidad misma de creación de estas entidades y no se obedecería al principio de especialidad que justifica la necesidad de su creación.

En cuanto a las potestades, el art. 4.2 LRBRL indica que las leyes de las CCAA concretarán cuáles de las enumeradas en el apartado 1 de ese artículo serán de aplicación a las entidades menores.

\footnotetext{
${ }^{90}$ En todo caso se respetarán las siguientes reglas: a) La iniciativa corresponderá indistintamente a la población interesada o al Ayuntamiento correspondiente. Este último debe ser oído en todo caso. b) La Entidad habrá de contar con un órgano unipersonal ejecutivo de elección directa y un órgano colegiado de control, cuyo número de miembros no podrá ser inferior a dos ni superior al tercio del número de Concejales que integren el respectivo Ayuntamiento. La designación de los miembros del órgano colegiado se hará de conformidad con los resultados de las elecciones para el Ayuntamiento en la Sección o Secciones constitutivas de la circunscripción para la elección del órgano unipersonal. No obstante, podrá establecerse el régimen de Concejo Abierto para las Entidades en que concurran las características previstas en el número 1 del artículo 29. c) Los acuerdos sobre disposición de bienes, operaciones de crédito y expropiación forzosa deberán ser ratificados por el Ayuntamiento.
}

${ }^{91}$ BLASCO DIAZ, J.L. op cit. pág. 69. 


\section{4.- Los límites establecidos para la regulación de las entidades locales menores}

La LRBRL en su artículo 45 dejaba amplio margen por parte de las CCAA para crear las ELM, sin embargo estableció unos límites en que éstas últimas se habían de regular:

1.- Han de preexistir como núcleos separados de población. Dichos requisitos vienen recogidos en los art. 42 TRRL y 40 y 43.2 RPDT. La delimitación territorial donde va a descansar dicha entidad es un fundamento básico, necesario y primordial, estableciéndose que dichos territorios tengan características específicas o más bien intereses $^{92}$ específicos diferentes a los del municipio. El art. 47 RPDT establece que: "Para determinar el territorio de las EATIM que no lo tuvieren delimitado con anterioridad, se tendrán en cuenta, dentro de lo posible, las siguientes normas:

Primera. Cuando se trate de una parroquia rural constituida en EATIM, los límites serán los mismos que tenga la parroquia que haya servido de base a su reconocimiento legal, según la demarcación eclesiástica vigente.

Segunda. Cuando se trate de un Concejo abierto de carácter tradicional o de un antiguo municipio anexionado a otro, el territorio propio de la EATIM será, respectivamente, el que correspondiere al ámbito territorial del Concejo abierto o al primitivo término municipal anexionado.

Tercera. Cuando se trate de núcleos urbanos o rurales que no tengan las características de los anteriores, el ámbito territorial de la nueva Entidad estará referido al casco ${ }^{\mathbf{9 3}}$ de la parroquia, lugar, aldea, anteiglesia, barrio, anejo, pago u otro grupo semejante y, además, a los terrenos circundantes que posean o cultiven los vecinos de la Entidad o constituyan el patrimonio de ésta, siempre que pueda establecerse fácilmente la línea divisoria entre esos terrenos y los que pertenezcan a los núcleos inmediatos.

\footnotetext{
${ }^{92}$ BLASCO DIAZ, J.L.: ob cit pág. 62.

93 BLASCO DIAZ, J.L.: La STS de 24 de mayo de 2007 define "casco" como sustrato territorial para la delimitación de una nueva entidad se hace sobre la base de una cierta homogeneidad tradicional del asentamiento histórico que por esta circunstancia obtiene el reconocimiento de EATIM.
} 
Cuarta. En los demás casos el Ayuntamiento deberá asignar a la nueva Entidad el ámbito territorial que sea preciso para el cumplimiento de sus fines”.

Siguiendo a BLASCO DIAZ" "la existencia del núcleo de población debe conectarse con la concurrencia de intereses propios de la comunidad vecinal afectada", que sean diferentes y especiales con relación a los intereses del propio municipio. ¿Cómo se pueden determinar o identificar esos intereses específicos?. En algunos casos puede ser mediante el reconocimiento de que una materia ha sido tradicionalmente del interés de ese núcleo, o bien por la existencia históricamente de bienes o derechos de esos vecinos, incluso las características del propio núcleo de población. En Castilla y León se recoge dicha justificación en su legislación autonómica ${ }^{95}$, afirmándose que es debido a la existencia de bienes, derechos o intereses peculiares y propios de los vecinos del núcleo, diferentes a los comunes que existen en el municipio.

2.- Se debe respetar la denominación tradicional - caseríos, parroquias, aldeas, barrios etc....- o la que establezcan las leyes, se supone que en defecto de lo anterior aunque parece una contradicción.

3.- La iniciativa para poder constituirse corresponde o bien a la población interesada en la misma, o al ayuntamiento donde radiquen, al que habrá que oír siempre en el expediente $^{96}$. La petición de los vecinos será el sistema más habitual para iniciar la constitución de una entidad local menor. En dicha petición será necesario identificar los derechos e intereses de que se trate y los vecinos podrán firmar por otros que no sepan hacerlo, a su ruego. Es importante resaltar que no hay norma que reconozca a los

\footnotetext{
${ }^{94}$ BLASCO DIAZ, J.L. op cit pág. 63.

${ }^{95}$ La Exposición de motivos de la Ley 1/1998, de régimen jurídico de Castilla y León afirma lo siguiente: "Por otra parte, la deseable descentralización funcional con el acercamiento de la Administración a los vecinos y la conveniencia de la participación de éstos en las decisiones que directamente les interesan conduce a la regulación de las entidades de ámbito territorial inferior al municipio en un sentido abierto y flexible que posibilite su creación, siempre que exista un substrato material mínimo y una voluntad de autoadministración".

${ }^{96}$ La regulación sobre la constitución de las EATIM está recogida en el Reglamento de Población del año 1986, en concreto en los art. 42 a 44, donde, y en síntesis, se recogen los requisitos para la creación de las mismas (petición escrita de la mayoría de los vecinos residentes en el territorio que haya de ser base de la Entidad o por acuerdo del Ayuntamiento; información pública vecinal durante el plazo de treinta días; informe del Ayuntamiento sobre la petición y reclamaciones habidas; resolución definitiva por el Consejo de Gobierno de la Comunidad Autónoma correspondiente) y los trámites no demuestran ninguna peculiaridad o diferencia que las que hemos visto al analizar tanto la normativa preconstitucional como la autonómica.
} 
vecinos que lo promueven, el derecho a constituirse en ELM, nunca se ha reconocido como hemos visto, a lo largo de la evolución histórica de estos entes y menos aún con el régimen constitucional actual, donde la autonomía se predica del municipio (así lo afirmaba el Consejo de Estado en sendos dictámenes de 22 de diciembre de 1981 y de 1 de junio de 1983).

4.- Que la eficacia en la prestación de los servicios públicos municipales no disminuya: Si el fin último de la creación de ELM es la administración descentralizada de esos núcleos de población, es imprescindible que dicha intencionalidad pivote sobre la eficacia y eficiencia a la hora de prestar servicios o ejercitar competencias. Por lo tanto se debería acreditar la suficiencia de recursos. Y a tal fin se deberá realizar una valoración de la forma de prestar los servicios por parte de la comunidad autónoma que es la administración competente para la creación de estas entidades ${ }^{97}$.

En varias de las regulaciones autonómicas está recogido como uno de los requisitos para la constitución de una entidad de estas características el que no se produzca una notoria pérdida de calidad en la prestación de los servicios generales del municipio. Se debe, pues, garantizar una suficiencia financiera, ya que el no hacerlo conllevaría a determinar la imposibilidad de su creación. De este modo, la Sentencia TSJ de Castilla y León 2 de febrero de 2010 analizando los requisitos necesarios para la creación de las ELM insiste en la necesidad de que antes de crear las entidades locales menores se pondere y tenga en cuenta la voluntad manifestada por el legislador sobre la primacía del interés autonómico en los procesos de creación de nuevos entes territoriales, como se expresa en el preámbulo de la LRBRL; de ahí que las entidades locales menores tengan carácter contingente y voluntario (STC 214/1989), cuya resolución definitiva corresponde al Consejo de Gobierno de la Comunidad Autónoma (art. 42.1 .d) TRRL y art. 42.1.d) RP. Debemos puntualizar que la potestad para crear entidades de ámbito territorial inferior al municipio es discrecional (arts. 40, 41 y 42 RP y 47.2 .b) LRBRL y 42 del TRRL), pero exige que todos los elementos reglados sean respetados. [...] "no existe nada parecido a un derecho subjetivo por parte de un

\footnotetext{
${ }^{97}$ A tal efecto podemos citar la STS 21 de septiembre de 2006. Por otra parte quiero destacar que una de las primeras versiones del borrador de la LRSAL introducía un sistema de evaluación de los servicios prestados por las ELM a efectos de determinar si éstos eran eficaces o no. Dicha previsión no ha sido incluida en el texto finalmente aprobado.
} 
núcleo diferenciado y con características peculiares para erigirse en Entidad local menor (jamás fue así y menos una vez constitucionalizada la autonomía municipal). Pero debemos añadir que el ejercicio de la potestad discrecional debe serlo respetando y defendiendo los intereses generales de ordenación territorial; y la jurisdicción debe evitar con sus resoluciones, en su caso la arbitrariedad."Deja sentado el tribunal la insuficiente acreditación del cumplimiento del requisito relativo a la existencia de recursos que garanticen el cumplimiento de los fines de la Entidad Local que se pretende constituir. Uno de los requisitos que exige la normativa autonómica de Castilla y León es el de la "Existencia de bienes, derechos o intereses peculiares y propios de los vecinos del núcleo, distintos de los comunes al municipio, que puedan justificar la constitución", y en el caso expuesto lo único que se dice es que la entidad local que se desea constituir contaría con un número importante de hectáreas en montes de utilidad pública de cuya explotación podría obtener determinados ingresos, resultando también de varios documentos aislados que la entidad tiene ingresos por otras causas; pero no se llega a aportar una memoria o estudio de carácter económico que analice con un mínimo de rigor unas previsiones sobre ingresos y gastos que sirvieran en su caso de soporte para la confección de unos presupuestos. Y además resulta que esos bienes, que pertenecerían al término territorial de la nueva entidad local que se constituiría, no ha quedado acreditado que sean "peculiares y propios de los vecinos del núcleo distintos de los comunes al municipio".

En las regulaciones autonómicas se prevén los recursos necesarios que deberán formar las haciendas de estas entidades, y existiendo, en Castilla y León, otras opciones como la posibilidad de firmar convenios de colaboración con el municipio al que pertenecen donde se regulen las posibles aportaciones económicas y la gestión de las competencias objeto de delegación si las hubiera. Si bien la experiencia nos enseña que raros son los casos donde se han firmado convenios de colaboración en este sentido, entendemos que es una práctica positiva y ventajosa que ahorra muchos problemas y discrepancias en la no siempre fácil ni pacífica relación entre una ELM y el municipio al que pertenece ${ }^{98}$.

\footnotetext{
${ }^{98}$ Para ilustrar esta herramienta me gustaría aportar la experiencia práctica que en dos municipios de Castilla y León se ha hecho con respecto a la regulación, aprobación y firma de Convenios de colaboración de ELM con sus ayuntamientos, y que con el caso de Tordesillas y sus dos Juntas VecinalesVillamarciel y Villavieja- de fecha 13 de diciembre de 2011 (Valladolid) y el de Carrión de los Condes con su única Junta Vecinal-Torre de los Molinos- en octubre del 2.013 (Palencia), donde se regulan las
} 
En cuanto al elemento poblacional que forma parte de la ELM, es importante señalar (tema que no es baladí y que retomaremos en el momento de tratar el tema referente a los bienes comunales) que los habitantes de la ELM constituyen legalmente población del municipio matriz, ya que sólo al ayuntamiento le incumbe la función de empadronar dentro del término. Por ello solo existe una vecindad, que es la municipal, es decir, se es vecino de un municipio, no de una ELM ${ }^{99}$. Esto no es impedimento para que los habitantes de la ELM tengan un sentimiento de vinculación de modo especial a la localidad en la que desarrollan de forma más directa su vida, sentimiento que en la mayor parte de los casos les lleva a considerar como vecinos efectivos únicamente a los que habitan en la ELM. Si bien hay que puntualizar que pese al concepto legal de "vecindad" los habitantes de la ELM gozan de derechos que les son privativos y no alcanzan a los restantes miembros del municipio, tales como el formar parte del Concejo Abierto, la participación en los aprovechamientos comunales etc.

Quisiera destacar que en algunas CCAA se exige, como requisito para la creación de estas entidades, el de una población mínima: cincuenta habitantes en La Rioja y Valencia, cien habitantes en Navarra, doscientos cincuenta habitantes en Aragón ${ }^{100} \mathrm{y}$ quinientos en Cantabria, aspecto que no se recoge en la normativa de Castilla y León ${ }^{101}$.

relaciones de colaboración y coordinación, relaciones de control respecto de las competencias delegadas, y lo que es más importante y novedoso: la colaboración económica en cuanto a los servicios prestados por delegación, y una participación anual del municipio hacia las ELM con unas variables parecidas a las que regulan la PTE, como pueden ser la población, el esfuerzo fiscal etc... lo cual soluciona numerosos interrogantes y evita conflictos tan frecuentes como los que se dan entre Ayuntamientos y ELM respecto de la gestión del abastecimiento del agua o del pago del contrato de servicio de alumbrado, fuentes de continuas discusiones.

${ }^{99}$ RUIZ RODRIGUEZ, F. op cit pág. 59: ...y ello porque solo al ayuntamiento corresponde la formación y conservación del Padrón de habitantes, que incluye, no los de uno o más pueblos, sino a todos los del municipio.

${ }^{100}$ RODRIGUEZ CATIVIELA, V. "Las entidades locales menores en Aragón: situación y perspectivas" Revista Aragonesa de Administración Pública, $n^{\circ}$ 5. Zaragoza. 1994. Pp. 445-462: "En Aragón se hallan constituidas 40 entidades locales de ámbito territorial inferior al municipal: 38 en la provincia de Huesca, y 2 en la de Zaragoza, no existe ninguna en Teruel. [...] La realidad nos muestra un cierto decaimiento de este tipo de entidades en los últimos años. [...]. La motivación [...] viene expresada así: "en razón tanto a la escasa población como a la falta de funcionamiento de la misma como entidad local con personalidad jurídica propia, lo que justificaría su disolución al apreciarse la existencia de notorios motivos de necesidad administrativa, conforme a lo previsto en los art. 44 y 45 TRRL y 48 y 49 RP".

${ }^{101}$ Art. 52.2 d) Ley 1/1998, de 4 de junio de régimen local de Castilla y León: "El número mínimo de habitantes y la distancia del núcleo principal que deban darse se determinarán reglamentariamente". Aspecto que no se ha recogido hasta el momento. Resulta ilustrativa la STSJ de Castilla y León de 2 de febrero de 2010, que dice: [...] Por otro lado no puede obviarse que el número de vecinos de la entidad resultante sería tan sólo de veintidós, circunstancia ésta que, y aún cuando el artículo 52.2.d) de la Ley 


\section{5.- La organización de las entidades locales menores}

Otro de los límites que recogía la LRBRL era el referido a la organización, al establecer que el régimen orgánico de las ELM debería respetar los siguientes estamentos:

- Tenía que existir un órgano unipersonal ejecutivo de elección directa.

- Tenía que existir un órgano colegiado de control. Según FERNÁNDEZ CRIADO $^{102}$ esto era una novedad, y afirma que, con la redacción otorgada al precepto, pareciera que no se le reconocen facultades resolutorias a este órgano, sino únicamente de control, y que no habría acuerdos de dicho órgano colegiado, sino resoluciones del presidente. Opinión que no compartimos ya que la regulación autonómica ha demostrado que se han atribuido competencias a uno y otro órgano y que la asamblea vecinal o junta vecinal sí que tiene capacidad decisoria.

- El órgano colegiado podrá sustituirse por el sistema de concejo abierto.

Tanto en el TRRL como en el ROF se regulan de una manera genérica, las atribuciones del Alcalde pedáneo y de la Asamblea Vecinal, así como la constitución, modificación o supresión de las mismas ${ }^{103}$. El órgano unipersonal sería el alcalde

1/1.998 establezca que el número mínimo de habitantes se determinarán reglamentariamente, necesariamente habrá de ser ponderada si se tiene en cuenta el contenido del certificado de la SecretariaInterventora del Ayuntamiento [...], en el que se apunta la clara tendencia a la despoblación del municipio, con lo que difícilmente quedaría garantizada la pervivencia del nuevo núcleo en el futuro. En este mismo sentido convendrá significar que la decisión a adoptar exige la previa valoración global de todas las circunstancias concurrentes desde una perspectiva de futuro, debiendo tenerse en cuenta, no sólo la necesidad de mantener un nivel adecuado en la prestación de los servicios públicos, sino también la propia "viabilidad" de los nuevos entes y la "racional probabilidad de su subsistencia", parámetros éstos que son utilizados en la jurisprudencia del Tribunal Supremo (así la sentencia de 15 de junio de 1.984). Y por lo mismo tampoco podrá prescindirse de la voluntad y de los intereses del resto de las entidades afectadas, de las que han manifestado su oposición el Ayuntamiento de Valderrueda y la Entidad Local Menor de Villacorta.

102 FERNÁNDEZ CRIADO, J. "Régimen actual y futuro de las Entidades Locales Menores". Revista Diputación de León, Vol. 25 nº 60. León 1985. Pág. 33.

${ }^{103}$ MENÉNDEZ GARCIA, P. op cit: pág. 1198 señala el autor que los referidos preceptos (en relación con lo recogido en el TRRL y en el ROF respecto de las atribuciones asignadas a los órganos de las EATIM) no alteraron sustancialmente el régimen jurídico que se contenía en la LRL de 1955, pero detrás de esta aparentemente o permanencia del régimen jurídico anterior, subyace un cambio radical de configuración. 
pedáneo $^{104}$, regulada esta figura en los art. 40 TRRL y 145 ROF, los cuales no han sido derogados; y el órgano colegiado sería la junta vecinal (art. 41.1 TRRL y 53, y 46 RPDT), compuesta por el alcalde pedáneo y los vocales ${ }^{105}$.

\section{6.- El funcionamiento de las entidades locales menores}

Las juntas vecinales, como órgano colegiado de naturaleza local como se acaba de ver, deben ajustar su funcionamiento a lo dispuesto con carácter común para las entidades locales, adoptándose los acuerdos por mayoría de votos. Pero dicha remisión normativa no significa que sean aplicables a las juntas vecinales todas las disposiciones relativas al funcionamiento de los municipios, ya que la remisión lo es a los art. 46 a 52 TRRL, es decir, al régimen de celebración de las sesiones ordinarias y extraordinarias y formalidades del libro de actas ${ }^{106}$.

En cuanto al funcionamiento, dice el art. 53 TRRL, que se ajustarán a lo dispuesto con carácter general para las EELL, salvo en el caso de los concejos abiertos, que se respetarán usos, costumbres o tradiciones locales. Anteriormente se preveía que el

\footnotetext{
${ }^{104}$ RUIZ RODRIGUEZ, F. op cit. “El submunicipio...”. pág. 52: Las leyes municipales de 1877 y 1935 denominaron Presidente al Alcalde pedáneo. Fue el Estatuto Municipal de 1924 el que consagró legalmente la calificación de "Vecinal" referida a las Juntas de los pueblos y conservando el de Presidente. Critica el autor el nombre de alcalde pedáneo, "no ya solo por su anacronismo, sino principalmente por la noción de inferioridad que envuelve, siendo sustituido en la práctica". Critica esta denominación "porque la designación no corresponde en realidad a las funciones actuales del Presidente de la Junta, y por el escepticismo con que ha sido generalmente acogida, sin duda por el tonillo de inferioridad que se desgaja del término". Sigue diciendo el autor que los antiquísimos orígenes del nombre- los romanos denominaba pedáneo al funcionario que administraba justicia de pie, sobre la marcha, en asuntos de escasa importancia), es preciso no olvidar que si la Ley de 1845 empleó tal nombre, fue debido a que en mentada época los alcaldes tenían designadas atribuciones, no solo administrativas, sino también judiciales. Desaparecidas éstas desapareció lógicamente tan singular calificativo, sobre el que puso su losa sepulcral toda la legislación municipal posterior, incluido el Estatuto. El legislador de 1945 lo resucita y acoge en sus articulaciones de 1950 y 1955.
}

${ }^{105}$ SANCHEZ SANTIAGO, J.L. "El sistema del concejo abierto en las entidades de ámbito territorial inferior al municipal”. Valladolid. 1987 pág. 54: el art. 41 TRRL señala las atribuciones del órgano colegiado de control, la asamblea o junta vecinal. Si examinamos con detenimiento las atribuciones del órgano de control de dicho artículo nos damos cuenta de que a pesar de ser un órgano de control no se le ha dado la atribución de controlar y fiscalizar a los órganos de gobierno, cosa que sin embargo, sí se concede al Ayuntamiento Pleno en el art. 22.2 ) LRBRL.

${ }^{106}$ STSJ Cantabria 9 de abril de 1987: esta remisión no implica la exigencia de dictamen de letrado e informe del secretario para la adopción de acuerdos de defensa de los bienes y derechos de las entidades locales, dada la precariedad y falta de estructura orgánica de las propias juntas vecinales. 
Secretario fuera miembro no representativo de las Juntas Vecinales (art. 98.2 ROF de 17 de mayo de 1952 y 130.2 y 136.3 del Reglamento de Funcionarios de Administración Local de 1952), lo cual no deja de ser llamativo, aspecto que hoy en día no está regulado ya de esa manera ${ }^{107}$.

Recordemos que en la regulación anterior se disponía que "en toda entidad local menor, salvo en aquellas que tradicionalmente vinieran funcionando en régimen de asamblea vecinal las cuales continuarán rigiéndose en la misma forma, habrá una Junta Vecinal compuesta de un Alcalde Pedáneo y de dos vocales”. Autores como RUIZ RODRIGUEZ 108 , criticaron la "desdichada o al menos confusa" redacción de la norma en su momento, pues afirma el autor que: "parece deducirse [...] que la ley reconoce dos formas distintas en el funcionamiento de las inframunicipalidades: el tradicional sistema de Concejo Abierto o Asamblea Vecinal (en que todos los electores son concejales) y el sistema moderno de Junta Vecinal (en el que sólo tienen calidad concejil los vocales de la misma). En otras palabras, que la dirección de la entidad corresponde, multitudinariamente, a todos los electores presididos por el Alcalde pedáneo (en el caso de la asamblea concejil) o bien que corresponde sólo a los dos vocales bajo la presidencia del pedáneo (en el supuesto de Junta vecinal), y de aquí que en el primer caso no existirá junta vecinal [...]”. Este autor insiste que la cuestión para él estaba clara y que la junta vecinal es preceptiva en toda clase de ELM cualquiera que sea su sistema de gobierno. Lo abona el propio art. 76 de la ley que parece excluirlas en el caso de asamblea vecinal y en realidad, se remite a los precedentes que venían rigiendo su funcionamiento (art. 190 Estatuto Municipal y 70 Ley Municipal de 1935), los que prescriben el nombramiento de la Junta Vecinal por la asamblea de vecinos, teniendo cada una de ellas sus funciones privativas respecto del gobierno y administración de la localidad. Realidad que hoy en día está plenamente superada y diferenciada.

\footnotetext{
${ }^{107}$ RUIZ RODRIGUEZ, F. op cit, pág. 52: Expresa este autor que el Secretario como miembro no representativo de la Junta Vecinal en aquel momento, era una cuestión importante que no se trataba con suficiente atención en la ley de la época, y que simplemente ventilaba con una indicación de que se imponía la existencia de un Secretario a cada Corporación Municipal, deteniéndose en las micro municipalidades (municipios inferiores a 500 habitantes), sin hacer alusión alguna al Secretario de las inframunicipalidades, a veces más importantes.
}

${ }^{108}$ Op cit pp. 51,52. 
Ahondando en el régimen de sesiones de las Juntas Vecinales éstas se amoldarán, dice la normativa, a lo dispuesto en el ROF para la Junta de Gobierno. Y dentro del régimen de funcionamiento ha sido habitual encontrarnos con el problema relativo al cómputo del quórum de asistencia, ya que el fijado por el art. 90.1 ROF dice que necesariamente debería haber tres miembros, lo que nos llevaría al absurdo, en mi opinión, que con que faltara uno de ellos se imposibilitaría celebrar la sesión. Ante esta situación y varias consultas, la JEC ha instado la revisión de dicho quórum. Entiendo que hoy en día este problema ha quedado superado por aplicación analógica de la modificación operada por la Ley Orgánica 2/2011 que para los municipios de menos de 100 habitantes y que funcionaran con un número de tres concejales, estableció que con dos que asistan a la sesión se entiende quórum suficiente. (cfr. Dictámenes de la JEC 18 de septiembre de 1992 y 18 de enero de 1994).

En cuanto al funcionamiento de las ELM en régimen de Concejo Abierto nada se precisa de manera específica al respecto en el capítulo XX de la LRBRL, ni nada se menciona de este régimen particular ${ }^{109}$, si bien y como dice ORDUÑA REBOLLO ${ }^{110}$ : “la aldea seguirá viviendo y con ella el Concejo abierto". La LRBRL únicamente señala que, no obstante el régimen indicado anteriormente, se podrá establecer el régimen de Concejo Abierto para las entidades en que concurran las características previstas en el art. 29.1 LRBRL. Así y partiendo de lo dispuesto en los arts. 29 y 30 LRBRL que tienen carácter básico, en Castilla y León se recogió en la Ley 1/1998 (LRLCYL), en su artículo 72, que los ayuntamientos y las ELM podrán funcionar mediante este sistema en los supuestos recogidos en la legislación básica de régimen local. Dicho artículo ha sido recientemente modificado por la Ley 7/2013, de Ordenación, Servicios y Gobierno de Castilla y León (LORSEGO) haciendo una remisión también a la normativa básica estatal e incluyendo a las ELM.

\footnotetext{
109 ORDUÑA REBOLLO, E. "La evolución del concejo abierto". Revista de estudios administrativos locales y autonómicos, $n^{\circ}$ 237. Madrid 1988, pág. 851: "en cuanto a las norma que regulan las ELM cuyo órgano de gobierno denomina el reglamento Junta Vecinal, deshaciendo los equívocos del Real Decreto Legislativo disponen la constitución y régimen de sesiones "sin perjuicio de los casos en que proceda el régimen de concejo abierto"; vid. COSCULLUELA MONTANER, L. "El concejo abierto" Revista de estudios administrativos locales y autonómicos, $n^{\circ} 234,1987$ pág. 200: "Origen esencialmente leonés y castellano, pero que se extendió también a otros reinos españoles...".

${ }^{110}$ Op cit. Pág. 851.
} 
Nuestra comunidad autónoma muestra un no desdeñable porcentaje ${ }^{111}$ en cuanto a municipios que se regulan por este peculiar régimen, si bien, desde las elecciones del año 2011, a raíz de la modificación operada por la LO 2/2011, la mayoría de los municipios con este régimen derivado de tener una población inferior a 100 habitantes, pasan a funcionar en régimen común con tres concejales. En las ELM nada se dice, es más, se aprueba en época electoral el acuerdo ${ }^{112}$ que da cumplimiento a lo preceptuado en el art. 14 del Real Decreto 605/1999, de 16 de abril de regulación complementaria de los procesos electorales, que determina cuáles de aquellas entidades van a funcionar en Junta Vecinal y cuales mediante Asamblea Vecinal. El art. 45 LRBRL se mostraba reservado pues todo lo redirigía a la regulación autonómica que se efectuara en su caso $^{113}$.

Con relación a este tema encuentro especialmente significativo el supuesto regulado en la Comunidad Autónoma de Aragón por el que a través de la Ley 9/2009 de Aragón, de 22 de diciembre reguladora de los concejos abiertos, choca o incide en manera especial la nueva regulación que realiza la Ley Orgánica 2/2011. La duda a plantear es si esta nueva regulación del régimen del concejo abierto afecta únicamente a los municipios o también a las ELM. Debemos recordar que el propio art. 45.2 LRBRL contiene una remisión al art. 29 de la misma ley, remisión que queda ahora a la nueva redacción, permitiendo que se establezca el régimen de concejo abierto para las entidades en que concurran las características previstas en su apartado primero. Al contener esta remisión expresa surge el interrogante siguiente: al haber desaparecido toda obligación de funcionamiento en concejo abierto por motivo del criterio de población, ¿existe impedimento en que la legislación autonómica sobre entidades locales menores permita que éstas se acojan al sistema de concejo abierto sin ser este su

\footnotetext{
${ }^{111}$ MERINO ESTRADA, V. "El régimen Local y el Concejo Abierto en Castilla y León". Jornadas sobre el Concejo Abierto. Junta de Castilla y León. Valladolid. 1989. Pp. 97 y 98. La realidad es variable dependiendo de la zona, ya que en provincias como León o Zamora este fenómeno es apenas existente, sin embargo en otras como Burgos con unos 81 municipios menores de 100 habitantes o Soria con unos 62 , es muy significativo.

${ }^{112}$ Citaremos como ejemplo el Acuerdo de la Subdelegación del Gobierno en la provincia de Palencia de 28 de febrero de 2011 (BOP 2 de marzo de 2011) por el que se publica la relación de municipios y EATIM de la provincia con expresión de los concejales y vocales que corresponde elegir en las Elecciones Municipales, en este caso las de mayo de 2011.

113 DIEZ GONZALEZ, F.A. "Funcionamiento de municipios y entidades de concejo abierto". Jornadas sobre el Concejo Abierto. Junta de Castilla y León. Valladolid 1987. Pp.31.
} 
régimen tradicional?. Parece que del tenor literal del citado art. 45.2, mediante esa remisión indicada al art. 29 el cual recoge características que no se concretan en criterios numéricos de población, se deduce una respuesta afirmativa a la cuestión planteada $^{114}$, y extendiéndose la prohibición por ser una norma básica estatal.

\section{7.- La negación de la autonomía a las entidades locales menores}

Quedaría incompleta una definición de la naturaleza de estas entidades locales sin hacer una referencia a su posible nivel de autonomía ${ }^{115}$. Resulta claro, como recuerdan ciertos autores ${ }^{116}$, que la garantía constitucionalmente prevista se refiere sólo a determinadas entidades locales: provincias, municipios e islas, es decir, son éstas las que vienen recogidas en la Constitución como de existencia necesaria en el territorio nacional. Lo que resulta esencial es que, al no estar incluidas dentro del ámbito de acción de la garantía constitucional, la existencia de las mismas es potestativa ${ }^{117}$. De hecho autores como FERNÁNDEZ CRIADO ${ }^{118}$ afirman que con la distinción vista anteriormente entre entidad territorial y no territorial predicado de su naturaleza, afecta directamente a que no pueda reconocerse para las ELM el principio de autonomía, no sólo por estar éste reconocido a los entes locales territoriales, sino porque

\footnotetext{
${ }^{114}$ Circular Diputación de Huesca 2010 sobre la Ley 9/2009 de concejos abiertos: "Podría argüirse en defensa de la Ley 9/2009 que la legislación autonómica de ELM no se encuentra condicionada por la nueva reforma de la LOREG ya que ésta sólo pensaba en los municipios, como se desprende de su Preámbulo y de la tramitación parlamentaria, cuyos debates no trataron específicamente este tipo de entidades locales, e incluso podría señalarse a favor de esta tesis la circunstancia de no haber afectado la reforma al art. 199.7 LOREG.

${ }^{115}$ BLASCO DIAZ, JL “Descentralización,...” Pág. 50: “Entendemos que la realidad indica que en ningún caso nos encontramos ante entes dotados de autonomía plena para la gestión de sus intereses....". Pero recuerda el autor que el TS en sentencia de 19 de mayo de 2008 ha dicho que la autonomía que afirma la Constitución de los municipios y provincias y la Carta Europea de Autonomía Local de los entes locales, también corresponde a las entidades locales menores en las que se da el autogobierno vecinal, aunque lo único que sucede es que ha de realizarse en el ámbito competencial diseñado por el legislador.
}

${ }^{116}$ MENÉNDEZ GARCÍA, P. op cit. pág. 1196.

${ }^{117}$ Dictamen 567/2013, del Consejo de Estado al ALRSAL de 26 de junio de 2.013, nos recuerda que estas EATIM se encuentran configuradas en nuestro ordenamiento como entidades locales no necesarias o contingentes, siendo así su creación manifestación de la voluntad del municipio y expresión de su autonomía.

${ }^{118}$ Op cit. Pág.32. 
los art. 4.2 y 2.1 LRBRL atribuyen a las CCAA el mayor o menor grado de autonomía que se pueda asignar a estas ELM, y critica dicha situación cuestionándose ¿cómo se van a ejecutar competencias propias con autonomía según se recoge en el art. 7.2 LRBRL si no gozan de potestades adecuadas y reconocidas ${ }^{119}$ ?.

En cuanto a las ELM y la autonomía local constitucionalmente garantizada, si bien ésta se define como la potestad de darse un ordenamiento jurídico, y siguiendo a SOSA WAGNER, la misma está enclavada dentro del concepto de integración democrática de los entes locales, y que la "autonomía que se predica de los entes locales es una autonomía específica que sólo puede explicarse referida a los entes territoriales locales y en un contexto constitucional determinado. Cualquier intento de generalización en esta materia debe ser evitado pues está condenado a convertirse en un discurso hueco ${ }^{120,}$.

\section{2.- EL RÉGIMEN ELECTORAL DE LAS ENTIDADES LOCALES MENORES}

\section{1.- La regulación actual del régimen electoral de estas entidades}

La Ley de Elecciones de 17 de julio de 1978 cambia la regulación de la Ley de Régimen Local de 1955 según la cual los Vocales de las ELM eran elegidos por los concejales del Ayuntamiento de entre los vecinos de la ELM cabezas de familia y residentes en la misma, y el Alcalde Pedáneo, con los mismos requisitos personales, por el Gobernador Civil a propuesta del Alcalde del Ayuntamiento donde radique la ELM.

En su art. 29, la anterior ley señalaba que las ELM se componen por los Alcaldes Pedáneos y dos vocales cuando los residentes sean inferiores a 250 y cuatro Vocales cuando superen esta cifra. Estos Vocales serán elegidos por las correspondientes corporaciones municipales. Por lo que se ve ya no se exige que sean cabeza de familia y

\footnotetext{
${ }^{119}$ Vid. SOSA WAGNER, F. "La autonomía local” en Estudios sobre la Constitución Española en libro homenaje al profesor Eduardo García de Enterría (coord. por Sebastián Martín Retortillo Baquer), Vol 4. Ed. Civitas. 1991. pp. 3185-3226, en el sentido de no confundir autonomía en la gestión y desempeño de las competencias reconocidas o asignadas, con la garantía institucional de la autonomía, la cual solo es predicable y constitucionalmente garantizada respecto de las administraciones territoriales.
}

${ }^{120}$ SOSA WAGNER, F. op cit. “Manual de... ”. Pág. 50 
residentes en el municipio. Si bien se mantiene que los Vocales son elegidos ${ }^{121}$ por las Corporaciones municipales. Situación que puede dar lugar a una falta de sintonía al ser el Alcalde Pedáneo de elección directa pero la elección de los vocales va al margen de la voluntad de los residentes de la entidad.

Ya hemos visto que la LRBRL en su art. 45.2b) recogía lo siguiente, respecto de la organización de las ELM: "La Entidad habrá de contar con un órgano unipersonal ejecutivo de elección directa y un órgano colegiado de control, cuyo número de miembros no podrá ser inferior a dos ni superior al tercio del número de Concejales que integren el respectivo Ayuntamiento. La designación de los miembros del órgano colegiado se hará de conformidad con los resultados de las elecciones para el Ayuntamiento en la Sección o Secciones constitutivas de la circunscripción para la elección del órgano unipersonal". Por lo tanto la LRBRL establecía dos opciones de $\operatorname{organización~}^{122}$ de las ELM:

- la atribución del gobierno a un órgano unipersonal de ejecutivo y a un órgano colegiado de control;

- la propia de los municipios que funcionan en régimen de concejo abierto, un órgano personal y otro colegiado (Asamblea Vecinal) pero deben de cumplir los requisitos del art. $29 \mathrm{LBRL}$.

El art. 199.1 LOREG actual afirma al respecto de la elección de estas entidades que: “el régimen electoral de los órganos de las EATIM será el que establezcan las leyes de las CCAA que las instituyan o reconozcan, que, en todo caso, deberán respetar lo dispuesto en la LRBRL ${ }^{123}$ ". Artículo que no ha sido objeto de modificación alguna.

${ }^{121}$ ARNALDO ALCUBILLA, E. "El régimen electoral de las entidades locales menores" Revista de Derecho Administrativo, $n^{\circ} 103$ julio sept. 1999, pág. 385, dice siguiendo a Cosculluela Montaner y Muñoz Machado, que esta regulación es del todo punto criticable.

${ }^{122}$ ARNALDO ALCUBILLA, E. op cit. Pág. 385: "la norma reguladora de la totalidad de los procesos electores a las CCLL constituye el régimen supletorio de organización de las ELM, de aplicación en defecto de regulación por las leyes autonómicas, fundado precisamente en la existencia de un órgano unipersonal directamente elegido por los vecinos y un órgano colegiado de control designado en virtud de los resultados obtenidos por las distintas candidaturas en la sección constitutiva de la ELM".

${ }^{123}$ MORELL OCAÑA, L. "Las elecciones locales", en Libro homenaje a Carlos Ruiz del Castillo (coord. Manuel Aragón Reyes). 1985. Pp. 437-456: Critica el autor haciéndose eco de los dos grandes rasgos que caracterizan el sistema electoral local: la falta de sustantividad propia y la profunda discordancia entre legalidad y realidad que en el mismo se observa. Y como ejemplo de esta falta de sustantividad hace referencia al tratamiento desigual otorgado por el ordenamiento a la figura del Alcalde y a la de los Concejales, que qué decir en mi opinión respecto a la de Alcalde Pedáneo y a la de los vocales, pues dice 


\section{2.- La elección del alcalde pedáneo en la LOREG}

El art. 199.2 LOREG es copia casi literal del art. 29.2 de la Ley de elecciones de 1978 que acabamos de ver, y dice: “Los Alcaldes Pedáneos son elegidos directamente por los vecinos de la correspondiente entidad local por sistema mayoritario mediante la presentación de candidatos por los distintos partidos, federaciones, coaliciones o agrupaciones de electores". El órgano unipersonal ejecutivo que preside la Junta Vecinal (art. 39 TRRL) es pues elegido por sufragio universal, libre, directo y secreto por los inscritos en el censo electoral de la entidad inframunicipal entre los que presenten su candidatura a dicho cargo por cualesquiera entidad política (partido político, federación, agrupación de electores etc..). Resultará elegido el candidato que obtenga mayor número de votos populares. Para ser candidato al cargo son exigibles cualesquiera de los requisitos que se exigen para cualquier otro cargo representativo en una Corporación Local, por lo tanto mayoría de edad y no estar incurso en causa de inelegibilidad (art. 177 LOREG) y también pueden serlo ciudadanos de la UE residentes en España según el art. 177 LOREG. Lo remarcable es que no se exige tener la condición de vecino, así lo afirma la JEC al decir que si la legislación autonómica no lo exige expresamente, para ser candidato a Alcalde Pedáneo no es preciso estar empadronado en el municipio ni en la entidad local menor en la que el candidato presente su candidatura $^{124}$.

La convocatoria de las elecciones a Alcaldes Pedáneos o Presidentes de las Juntas Vecinales no presenta especialidad alguna, de manera que el Real Decreto de Convocatoria de las Elecciones Locales integra la renovación de la totalidad de las Corporaciones Locales. Y a efectos de la determinación del número de vocales de las Juntas Vecinales, ha de estarse al Real Decreto que, con ocasión de cada convocatoria, declare oficiales las cifras de población de derecho resultantes de la última rectificación padronal oficialmente aprobada.

el autor que la figura de Alcalde ha sido minuciosamente dibujada en su perfil y caracteres, mientras tanto la del Concejal (y esto lo añado respecto de la de Vocal) se desdibuja en su propio contenido, quedando la figura del Concejal a un papel completamente secundario. Vid. también ESCUIN PALOP, C. "El sistema electoral municipal” Revista de estudios locales y autonómicos $n^{\circ}$ 303. 2007. Pág. 93.

${ }^{124}$ Acuerdo JEC de 23 de enero de 2002 y 9 de abril de 2003. 
Las candidaturas al cargo de Alcalde Pedáneo en las ELM son uninominales sin suplente $^{125}$ (Acuerdo JEC 12 de abril de 1991), a diferencia de la de los municipios que funcionan en régimen de Concejo Abierto en las que junto al titular puede figurar un suplente, lo cual no deja de ser llamativo toda vez que aquellas pueden funcionar conforme a este régimen. Dicha candidatura puede ser simultánea a la de concejal del ayuntamiento donde este la ELM. Si bien el artículo 46 LOREG establece que ningún candidato puede presentarse en más de una circunscripción ni formar parte de más de una candidatura, este precepto ha de interpretarse en el sentido de que lo que mediante en él se prohíbe es ser candidato a la misma clase de cargos o ser presentado como candidato por más de una entidad política o en varias circunscripciones; pero no prohíbe la candidatura simultánea a dos cargos que legalmente no son incompatibles como el de alcalde pedáneo y concejal del municipio al que la entidad local menor perteneceAcuerdo JEC 15 de noviembre de 2004-. Cabe pues ser candidato a concejal en un municipio y a alcalde pedáneo en una ELM integrada en aquél, por no ser circunscripciones distintas en una misma clase de elecciones a los efectos del citado artículo 46.6 LOREG-Acuerdo JEC 15 de marzo de 1995 y 9 de octubre de $1997-{ }^{126}$. En Castilla y León sí está previsto en su regulación que se pueda poner un suplente.

Los requisitos formales para la presentación de candidaturas de Alcalde Pedáneo son los recogidos en la "Instrucción de la JEC de 4 de abril de 1991", cuyo contenido, a pesar de su vigencia indefinida, se reitera por el órgano superior de la Administración Electoral con ocasión de cada convocatoria electoral ${ }^{127}$. Y como nota añadida recordar la obligación de constitución de Mesa Electoral en cada ELM, aunque no alcanzara la cifra de 200 electores (mínimo fijado por el art. 23.6 in fine de la LOREG), en la que se

\footnotetext{
${ }^{125}$ Todas las leyes autonómicas prevén la elección directa por los electores por sistema mayoritario, si bien algunas como la de Cantabria o la de Castilla y León prevén que junto con el candidato se incluya un candidato suplente.

${ }^{126}$ En la regulación de Andalucía el art. 60 del RDMA prohibía la compatibilidad de la acta de concejal con el de Alcaldía o Presidencia de la ELA o de Vocal de su Junta Vecinal, prohibición anulada por la Sentencia del TSJA de 14 de abril de 2008, al considerar que uno y otro cargo no son incompatibles por principio y al no estar establecida la prohibición en la LDMA, el RDMA se había extralimitado. La LAULA solo contempla la compatibilidad del acta de concejal con la titularidad de una vocalía, pero omite referencia alguna sobre la posibilidad de compatibilizar el acta de concejal con la Presidencia de la Junta Vecinal de la ELA, algo que parece lógico por el superior nivel de dedicación que exige el ejercicio de este cargo.

${ }^{127}$ Lo reseñable de esta Instrucción es que recoge que la inscripción en el Censo o en el Padrón Municipal de Habitantes no es condición necesaria para ser candidato en las elecciones locales, siempre que se cumpla con la exigencia de no incurrir en causa de inelegibilidad ni tener antecedentes penales.
} 
dispongan de tres urnas: una para las elecciones municipales, otra para las de la ELM y una tercera para las elecciones autonómicas allí donde se celebraran coincidentemente $^{128}$.

Una vez nombrado el Presidente de la entidad no son pocos los casos de renuncia al cargo del mismo, y una vez aceptada la misma por la Junta Vecinal, la situación que se crea entiendo que debe solucionarse mediante la aplicación analógica de lo dispuesto en el art. 184 f) LOREG, es decir, la vacante debe atribuirse al candidato siguiente más votado, salvo que la candidatura se hubiera proclamado con suplente, que en este caso le correspondería a éste ${ }^{129}$. El mismo criterio habría que aplicar en caso de fallecimiento, incapacidad o inhabilitación. En el supuesto de que no exista suplente entraría en juego la constitución de una comisión gestora, figura que veremos más adelante. En Castilla y León, en concreto, en el caso de que se produzca una vacante y no exista suplente al respecto, la JEC tiene manifestado que deberá la Diputación Provincial designar un Alcalde Pedáneo Gestor, al que corresponderá nombrar a todos los vocales gestores, salvo que continúe en el ejercicio de dicho cargo el Vocal designado en su momento por la JEZ como candidato segundo en número de votos o, si dicho vocal ha fallecido o renunciado, exista suplente del mismo que deba ser nombrado por la Diputación Provincial Vocal Gestor (Acuerdo JEC 4 de octubre de 2004). En Navarra cuando la renuncia del presidente sea total, es decir sin reservarse su condición de vocal, la presidencia debe ser atribuida al vocal que le haya seguido en votos. En este caso, la vacante de vocal debe ser atribuida al candidato siguiente que más votos haya obtenido. Por el contrario, si la renuncia del presidente lo es solo a la presidencia, sin renunciar a su condición de vocal, la vacante de presidente ha de ser atribuida también al vocal que le haya seguido en votos, sin que sea necesario realizar ningún acto posterior, al no quedar vacante la plaza de vocal (TSJ Navarra 26 de enero de 2004).

\footnotetext{
${ }^{128}$ Habrá de proceder a la constitución de una mesa electoral por cada ELM, pero situándola en la cabecera del municipio para aquellas entidades que resultase imprescindible por razonas técnicas o de hecho, como pudiera ser la falta de locales adecuados por razones en las ELM o de personas capacitadas para constituir las mesas. En este caso cabría constituir una mesa electoral que incluya varias ELM con las siguientes urnas: una para las elecciones autonómicas, otra para las municipales y una urna por cada entidad local menor para la elección del Alcalde Pedáneo respectivo (JEC 15 y 29 marzo y 17 abril de 1995).
}

${ }^{129}$ Acuerdo JEC 24 de abril de 2002. 


\section{3.- Constitución de la Junta Vecinal}

En cuanto a la sesión constitutiva, el art. 142.1 ROF regula las circunstancias de la misma y dice que: "Se constituirán en la fecha que señale la JEZ una vez efectuadas las operaciones electorales previstas en el art. 199 LOREG, salvo que se hubiere presentado recurso contencioso electoral contra la proclamación del Alcalde Pedáneo, en cuyo caso no podrá constituirse hasta que se hubiere resuelto el mismo ${ }^{130 \text {, }}$.

Comparativamente con la sesión constitutiva de los Ayuntamientos observamos que para las ELM no se establece fecha prefijada como sí se hace para los municipios "el vigésimo posterior a la celebración de las elecciones ${ }^{131}$ ". Sería recomendable que se regulara dicho plazo, así por ejemplo, en la Comunidad Autónoma de Cantabria sí está establecido el mismo en la Ley 6/1994, que fija el 30ª́a posterior a la celebración de las elecciones.

El art. 199.1 LOREG se remite a lo regulado en las CCAA para la constitución de las Juntas Vecinales, y en concreto, en sus apartados 4.5.6 dice lo siguiente: " $L a$ designación de estos vocales se hará de conformidad con los resultados de las elecciones para el Ayuntamiento en la Sección o Secciones constitutivas de la entidad local menor. 5. La Junta Electoral de Zona determinará, aplicando el procedimiento establecido en el artículo 163, el número de vocales que corresponde a cada partido, federación, coalición o agrupación. 6. Realizada la operación anterior, el representante de cada candidatura designará entre los electores de la entidad local menor a quienes hayan de ser vocales."

Por lo tanto la JEZ debe proceder a la aplicación del sistema D'Hondt tomando los resultados obtenidos por cada lista de candidatos en las elecciones para concejales del Ayuntamiento al que pertenece la ELM, en la Mesa o Mesas que se constituyen para

\footnotetext{
${ }^{130}$ Por aplicación del art. 194.2 LOREG, hasta la constitución de las Juntas Vecinales continuarán en el ejercicio de sus funciones los miembros de la Junta Vecinal saliente.

${ }^{131}$ ARNALDO ALCUBILLA, E. "El régimen electoral de las ELM" Revista de Derecho Administrativo $n^{\circ}$ 103. Julio/Sept. 1999, pp. 383.: "Una posible razón justificativa podría inferirse de la dificultad material de que en la misma fecha se constituyeran el Ayuntamiento y las entidades inframunicipales de él dependientes, pero, en tal caso, la solución normativa podría ser otra como la de fijación del día inmediatamente siguiente, el vigesimoprimero".
} 
la misma. Así la JEZ determinará el número de vocales que le corresponde a cada formación política (JEC 30 de junio de 1987).

En cuanto a la designación de los vocales, una vez constituida la ELM, se observa que la LOREG no exige la condición de elector para ser Alcalde Pedáneo pero sí la exige para los Vocales de las Juntas Vecinales. Respecto de esta particularidad sí que deseo hacer un inciso en cuanto a la situación en Castilla y León. En la legislación del Estado se obliga a que la persona a designar como vocal sea un residente, pero en Castilla y León no está recogida tal necesidad, sin embargo la doctrina dimanante de la sentencia del TSJ de Valladolid 675/2010, de 16 de marzo ha sido esclarecedora ante esta situación, determinando que sí es exigible la condición de elector -inscrito en el censo electoral del respectivo ámbito territorial- de los Vocales nombrados por el Alcalde Pedáneo, y ello porque:

a) La circunstancia de que el artículo 199.1 de la LOREG se remita en cuanto al régimen electoral de los órganos de las entidades locales menores a lo que "establezcan las leyes de las Comunidades Autónomas que las instituyan o reconozcan, que, en todo caso, deberán respetar lo dispuesto en la Ley reguladora de las Bases del Régimen Local; en su defecto, será el previsto en los números siguientes de este artículo", no impide en el caso de que la Ley de Régimen Local de Castilla y León no regule expresamente las condiciones de elegibilidad de los Vocales de la Junta Vecinal que hayan de ser nombrados por el Alcalde Pedáneo -en cuanto a éstos, es decir, aquellos a los que no corresponde su proclamación directa por haber obtenido como candidato el segundo lugar en número de votos, su artículo 59.1 se limita a señalar que "Los Vocales de la Junta Vecinal serán nombrados por el Alcalde Pedáneo"- que deba acudirse con carácter supletorio a las previsiones específicamente contenidas sobre el particular en el régimen electoral general, y ello no sólo por la naturaleza supletoria que el propio artículo 199.1 atribuye a dicho régimen ("...en su defecto, será el previsto en los números siguientes de este artículo") sino también por aplicación del art. 149-3 in fine de la Constitución que contempla dicha naturaleza supletoria de la legislación estatal; y

b) La anterior consideración conlleva pues a lo dispuesto en el artículo 199.6 de la LOREG, en cuya virtud "Realizada la operación anterior, el representante de cada candidatura designará entre los electores de la entidad local menor a quienes hayan de 
ser vocales", límite inequívoco de elegibilidad en cuanto a las facultades discrecionales de designación directa de Vocales por el Acalde Pedáneo.

\section{4.- Elección en las ELM que funcionan en régimen de Concejo Abierto ${ }^{132}$}

En este tipo de régimen de funcionamiento la elección no se produce mediante elección de los vecinos a los concejales, sino que ellos mismos constituidos en Asamblea Vecinal gobiernan y administran sus intereses, y, como dice ARNALDO ALCUBILLA, para garantizar su operatividad se disponga la existencia de un órgano unipersonal, el Alcalde Pedáneo, con funciones propias, el cual es elegido directamente por los vecinos por sistema mayoritario ${ }^{133}$.

En el supuesto de vacante de la Alcaldía en este tipo de municipios por renuncia, fallecimiento o incapacitación, la sustitución corresponde, si no existe suplente, al siguiente candidato en número de votos, y si no hubiera más candidatos, por aplicación analógica del art. 182 LOREG ha de entenderse que se deberá nombrar un órgano unipersonal como gestor y que tendrá que asumir las funciones del Alcalde, nombramiento que recaerá en la Diputación Provincial o en el órgano competente de la Comunidad Autónoma, siempre teniendo en cuenta los resultados de la última elección municipal (JEC 10 de octubre de 1994).

\section{5.- La Moción de Censura en las ELM}

Regulado en el art. 197 LOREG (modificado por la LO 8/1999 del Pacto Local) el alcalde pedáneo puede ser sustituido mediante moción de censura. No difiere lo aquí regulado en cuanto al régimen previsto para la moción de censura en los municipios respecto de lo aplicable a las ELM, es decir, como requisitos se exigen la designación

\footnotetext{
${ }^{132}$ Vid. COSCULLUELA MONTANER, L/MUÑOZ MACHADO, S. "Las elecciones locales" Madrid 1979; COSCULLUELA MONTANER, L. "La Ley de reforma de las elecciones locales" Madrid, 1983.

${ }^{133}$ La JEC ha afirmado que las candidaturas a Alcalde en municipios que funcionan en Concejo Abierto se presentan en la misma forma prevista en general en la LOREG para la presentación de candidaturas y, por tanto, los electores no pueden votar a otros candidatos que aquellos que, presentados en forma por las entidades políticas, hayan sido debidamente proclamadas (JEC 21 de mayo de 1987).
} 
de un candidato a la alcaldía, la aceptación expresa del mismo, presentación de firmas autenticadas y exigencia de quórum de mayoría absoluta para que prospere la misma.

En Castilla y León está recogido de manera expresa en la normativa de régimen local. Merece la pena comentar la sentencia del TSJ de Castilla y León de 14 de diciembre de 2007 por la que se recurre la denegación de una Junta Electoral de Zona en nuestra comunidad autónoma de conceder la credencial a una alcaldesa pedánea elegida como resultado de una moción de censura correctamente planteada y tramitada, alegando dicha JEZ que no cabe la moción de censura en la figura de los alcaldes pedáneos. La sentencia comentada trae a colación otras tales como la de 11 de julio de 2001, la de 18 de noviembre de 2005 y más concretamente la STS de 14 de septiembre de 2001 donde se analiza que conforme a lo dispuesto en el art. 64.3 de la LRL, artículo que no es contrario a las previsiones del art. 197.1 c) LOREG sino que ambos se complementan, que procede aplicar la moción de censura en los supuestos de planteamiento a alcaldes pedáneos de ELM. Como circunstancias especiales se exige de quienes promuevan la moción de censura ser electores del municipio y por tanto estar incluidos en el censo electoral vigente al momento de presentación (STSJ Castilla y León 18 de mayo de 2007). Si bien estas normas están previstas para los municipios en los que se aplique el régimen de concejo abierto, sus reglas con aplicables para el caso de las entidades locales menores, se rijan por el sistema de concejo abierto o no (STSJ CYL 11 de julio de 2001).

En Cantabria se prevé la regulación de la moción de censura (al igual que en Castilla y León), en estos términos:

- El Presidente de la Junta Vecinal puede ser destituido de su cargo mediante moción de censura adoptada por la mayoría absoluta de los electores.

- La moción debe ser suscrita, al menos, por la mayoría absoluta de electores, e incluir el nombre del candidato propuesto para Presidente de la Junta Vecinal, quien quedará proclamado como tal en caso de que prospere la moción. La moción debe ser discutida y votada en el plazo de quince días desde su presentación, en un Pleno convocado al efecto. Ningún elector puede suscribir durante su mandato más de una moción de censura. 
- A los efectos previstos en el presente artículo todos los electores pueden ser candidatos y las firmas de los vecinos que suscriban la moción deberán ser autenticadas por Notario o el Secretario del Ayuntamiento respectivo.

\section{6.- La constitución de Comisiones Gestoras en las ELM}

Ante las posibles vacantes en las Alcaldías Pedáneas y Vocalías de las Juntas Vecinales, ya sea por falta de candidatos o de designación política, y por desarrollo del artículo 182 LOREG, se aprobó el Real Decreto 608/1988, de 10 de junio. Este Real Decreto regula un sistema excepcional en defecto de regulación autonómica, tal es el caso de Castilla y León donde la Ley 1/1998 no recoge nada al respecto, limitándose su art. 71.2 b) a señalar que "podrá acordarse la supresión de las ELM en los siguientes supuestos: Cuando celebradas elecciones locales, hubiesen quedado reiteradamente sin cubrir los órganos rectores de la entidad por falta de candidaturas. En este supuesto, iniciado el expediente de disolución y hasta que el mismo se resuelva, la Administración y gestión corresponderá al Ayuntamiento”.

El carácter dispositivo del término “podrán” empleado por la Ley de Castilla y León pone de manifiesto que la supresión de la Entidad Local Menor, cuando no se han presentado candidaturas a las elecciones, es una facultad autonómica que se puede ejercitar o no ${ }^{134}$. De modo que, en el caso de no ejercitarse dicha facultad, se debe constituir una Comisión Gestora de acuerdo con los criterios fijados por el Real Decreto 608/1988, de 10 de junio, que regula la constitución de Comisiones Gestoras en las Entidades Locales Menores ${ }^{135}$.

\footnotetext{
${ }^{134}$ En la Ley de ELM de Cantabria se recoge la iniciación de oficio de un expediente para la disolución de la Junta Vecinal cuando celebradas elecciones locales en la misma no pudieran renovarse los puestos de vocales o Presidente de la Junta Vecinal por falta de candidaturas. Solución que se podría adoptar en Castilla y León y que evitaría disfunciones tales como tener entidades locales menores sin constituir ni formar tan siquiera comisión gestora a lo largo de la legislatura completa, y no recurrir a las comisiones gestoras que al final van vocales medio obligados y una vez constituidas apenas funcionan.

${ }^{135}$ En la normativa de la Comunidad Valenciana se ha aprobado el Decreto 141/2010 que establece la existencia de la comisión gestora como órgano de gobierno provisional y las juntas vecinales como órgano de gobierno definitivo de las ELM.
} 
Dado que en el citado Real Decreto no se regula expresamente el vacío de poder que se puede producir en las ELM que se rijan por el sistema de Concejo Abierto, habrá que entender que, por aplicación extensiva del espíritu del texto, en aquellas ELM en régimen de Concejo Abierto en que no se presente candidato alguno al cargo de Alcalde Pedáneo, deberá designarse por la Diputación Provincial correspondiente un PresidenteGestor de dicha entidad ${ }^{136}$. Habrán de ser, por tanto, las Diputaciones Provinciales correspondientes las que procedan a la constitución de las Comisiones Gestoras en entidades locales; o, en su caso, a la designación de Presidente-Gestor en las que funcionan en régimen de Concejo Abierto, conforme a lo dispuesto en el Real Decreto estatal. Por lo tanto estas comisiones gestoras son órganos transitorios de gobierno.

${ }^{136}$ Informe EOP/LFV/MR/321/03, de 15 de octubre de la Subdirección General de Régimen Jurídico Local del Ministerio de Administraciones Públicas. 


\title{
3.- NATURALEZA Y REGIMEN JURIDICO DE LAS ENTIDADES LOCALES MENORES EN CASTILLA Y LEON
}

\section{1.- La estructura municipal en Castilla y León}

\section{La planta municipal en nuestra comunidad es actualmente un gravísimo} problema $^{137}$. Castilla y León cuenta con 2.248 municipios, pero es que con relación a las Entidades Locales Menores existen $2.225^{138}$, lo que muestra un mapa territorial muy $\operatorname{particular}^{139}$.

\begin{abstract}
${ }^{137}$ DIAZ LEMA, J.M. "El anteproyecto de Ley de racionalización y sostenibilidad de la administración local: ¿cambio de rumbo en la administración local española?”. Anuario de Gobierno Local 2012. Cuadernos de Derecho Local. Pág. 73: Comenta el autor que el problema de la denominada "planta local" ya hace años la doctrina y especialistas en el mundo local vienen llamando la atención sobre la necesidad de actuar sobre la estructura de la Administración local española. Vid. SOSA WAGNER, F. “Administración Local” en Derecho Público de Castilla y León, Lex Nova, Valladolid 2008 pág. 750, a propósito de la reordenación municipal en Castilla y León:"si ponemos la vista en eses panorama, que los optimistas creemos esperanzador, aplicar el cauterio a algunas estructuras administrativas en un acontecimiento menor, de escasa entidad incluso si pensamos en la necesaria desaparición en esta CA de muchos términos municipales que, por su escasísima población y sus desfallecientes recursos, arrastran una existencia fantasmal, de auténticos espectro, incapaces de proyectar siquiera la inquietante sombra que toda administración que se precie debe estar en condiciones de proyectar". Vid CALONGE VELAZQUEZ, A. "La planta municipal y las entidades locales menores en Castilla y León" Revista de estudios locales y autonómicos, $n^{o}$ 285, Enero-Abril 2001, pág. 139: “...la situación de la planta municipal en Castilla y León constituye un problema, que no dudamos en calificar, de gravísimo, cuando no de catastrófico y, desde luego, alarmante".
\end{abstract}

\footnotetext{
${ }^{138}$ En España existen 3716 entidades locales menores. En Cataluña por ejemplo existen en toda la CA únicamente 63. La influencia histórica y la declarada intención política de evitar y reducir en la medida de lo posible el minifundismo local explican que esta ordenación vigente supusiera una normativa de adaptación de este tipo de entidades existentes en el momento de su entrada en vigor; tan sólo se autorizó en dicha CA la continuidad de 49, prácticamente todas ellas en comarcas de montaña y titulares de montes de utilidad pública o en régimen comunal (TSJ Cataluña 26 de marzo de 2003). La realidad social que parece contemplar la ley catalana es la de una diversidad de núcleos, de asentamientos de población, fruto de la historia, esparcidos fundamentalmente por comarcas de montaña, que por distintas causas no alcanzaron la condición de municipio (o la perdieron), detentadores de un importante patrimonio propio o de sus vecinos que aconseja la conveniencia de administrarlo de forma autónoma (TSJ Cataluña 26 de marzo de 2003). En Andalucía 48, Aragón 43, Asturias 39, Baleares 1, Cantabria 524, Castilla La Mancha 42, Cataluña 63, Comunidad Valenciana 7, Extremadura 22, Galicia 9, Madrid 2, Navarra 347, País Vasco 340 y La Rioja 4.

139 SANZ RUBIALES, I. "Refuerzo competencial" Revista jurídica de Castilla y León número extraordinario. 2006. Pág. 61: "Esta realidad territorial implica, de forma inevitable, varias consecuencias en relación con el tratamiento de las competencias locales; por una parte, la capacidad de gestión de la inmensa mayoría de los municipios es muy reducida. No están capacitados para ejercer numerosas competencias. [...] Por otra parte, ante esta generalizada incapacidad municipal, las provincias pueden y deben jugar un papel importante en el refuerzo competencial de las entidades locales".
} 
La dispersión de la población y el carácter eminentemente rural de la misma hace que encontremos ciertas similitudes con la organización y población de otras CCAA, como puede ser Galicia. ${ }^{140}$ El número de ELM y su distribución por provincias en Castilla y León lo podemos a continuación ver en esta tabla:

Tabla Distribución de ELM por provincias en Castilla y León

\begin{tabular}{|c|c|}
\hline Provincia & Número de Entidades Locales Menores \\
\hline Ávila & 2 \\
\hline Burgos & 651 \\
\hline León & 1232 \\
\hline Palencia & 226 \\
\hline Salamanca & 19 \\
\hline Segovia & 17 \\
\hline Soria & 55 \\
\hline Valladolid & 9 \\
\hline Zamora & 14 \\
\hline TOTAL & $\mathbf{2 . 2 2 5}$ \\
\hline
\end{tabular}

Elaboración propia. Fuente: Registro de EELL. Ministerio de Hacienda y AAPP. A fecha 1 de diciembre 2014.

E1 86,81\% de estos municipios tiene una población inferior a 1.000 habitantes y un $77,54 \%$ de los mismos tienen una población inferior a 500 habitantes ${ }^{141}$. La propia Ley 1/1998, de 4 de junio de Régimen Local de Castilla y León recoge en su Exposición de Motivos la alarmante situación ante la que nos encontramos en esta comunidad, y aunque siendo larga la referencia, considero que merece la pena recordar los propios términos en los que se expresa el legislador: “......la grave situación municipal en la Comunidad, que se manifiesta, fundamentalmente, a través del gran número de municipios existentes, su dispersión geográfica y, demográficamente, de escaso tamaño, así como en clara regresión económica y administrativa. Este declive de una densa y dilatada historia municipal ha convertido a Castilla y León, en el ámbito rural, en un amplio territorio despoblado, en el que más que asentarse sobreviven minúsculos

\footnotetext{
${ }^{140}$ CASTRO BERMEJO, C. "Marco jurídico de la parroquia rural en Galicia” Revista de estudios locales y autonómicos, $n^{\circ} 276.1996$, pág. 179.

${ }^{141}$ DIAZ LEMA, JM. op cit, pág. 74: "Ciertamente este modelo de asentamiento no se reproduce en las CCAA más pobladas, ni los efectos de la despoblación llegan a tales extremos, pero el problema de fondo es una constante de toda la Administración local española". El autor critica acertadamente que los municipios españoles no cuentan con un número de vecinos suficiente para poder hacer eficiente la prestación de numerosos servicios locales, no para ofrecer la prestación de servicios nuevos que requiere la sociedad del siglo XXI. Vid. GRACIA HERRERO, FJ. Pp.532: "España es el tercer país de la UE en número de entes locales con 8.117. Delante estarían Francia con 36.682 y Alemania con 14.000. De esta cantidad solo 400 (un 5\% del total) superan los 20.000 habitantes y más de 3.822 municipios $(47 \%)$ tienen menos de 500 habitantes. (Fuente Portal de Entidades Locales del MINHAP a 25 de junio de 2014).
} 
núcleos de población con un gradual proceso de disminución y envejecimiento. La mayoría de estos núcleos, aunque conservan su condición de municipios, son incapaces, por carecer de medios personales y materiales, de autogobernar sus intereses, resultando inviables desde la perspectiva de una satisfacción racional y moderna de sus propias necesidades colectivas que constituye la justificación formal y material de su existencia institucional. En resumen, la amplitud de competencias frente a la escasez de recursos hace estéril el principio constitucional de autonomía municipal al no contar muchas Entidades Locales con otros medios financieros que las ayudas de otras Administraciones Públicas [...]”. Pero ante esta circunstancia no se afronta o no se toman en consecuencia medidas para corregirla ni mucho menos evitarla.

La Comunidad Autónoma de Castilla y León asume competencias sobre la materia de régimen local con la reforma estatutaria operada por la LO 4/1999, de 8 de enero de reforma de la LO 4/1983, del Estatuto de Autonomía de Castilla y León, y es en su artículo 34.3 donde se recogen ya las competencias de desarrollo normativo y de ejecución en materia de Régimen Local ${ }^{142}$. Por lo tanto la CA tiene competencias sobre la supresión y creación de municipios, la alteración de los términos municipales y todo lo relativo a las estructuras supra e inframunicipales, y la regulación de lo básico la tiene asignada el Estado (LRBRL). Así que CYL tiene absoluta disponibilidad sobre su estructura territorial local y por ello competencia para configurar una estructura apropiada a las necesidades actuales y al contexto presente.

El nuevo Estatuto de Autonomía de Castilla y León aprobado por la Ley Orgánica 14/2007, de 30 de noviembre, establece el marco regulador último que afecta a las entidades locales de nuestra comunidad ${ }^{143}$. En dicha normativa autonómica se realiza una enumeración de los diversos tipos de entidades territoriales locales

\footnotetext{
${ }^{142}$ Vid. BELLO PAREDES, S./ MEDINA ARNAIZ, T. “Castilla y León” Revista jurídica de Castilla y León. Monográfico $n^{\circ}$ 19. Septiembre 2009. Valladolid.

143 BELLO PAREDES, S. "La situación de las entidades locales en los estatutos de autonomía reformados: especial referencia al marco estatutario de Castilla y León". Revista Jurídica de Castilla y León $n^{\circ}$ 20. Enero 2010. Pág. 347. Dice el autor con relación a la aprobación del nuevo estatuto de autonomía que "se ha producido una regulación sustancialmente favorecedora del régimen local, que viene siendo desarrollada por medidas normativas y ejecutivas, y ello pese al elevado número de entidades locales que existe y que dificulta enormemente la concreción efectiva de los preceptos estatutarios".
} 
aludiendo, además de a los municipios y provincias, a las "demás entidades locales que con tal carácter puedan crearse conforme a la ley ${ }^{144}$,.

En este mapa se puede observar que la inmensa mayoría de las ELM están ubicadas de la meseta hacia el norte del país:

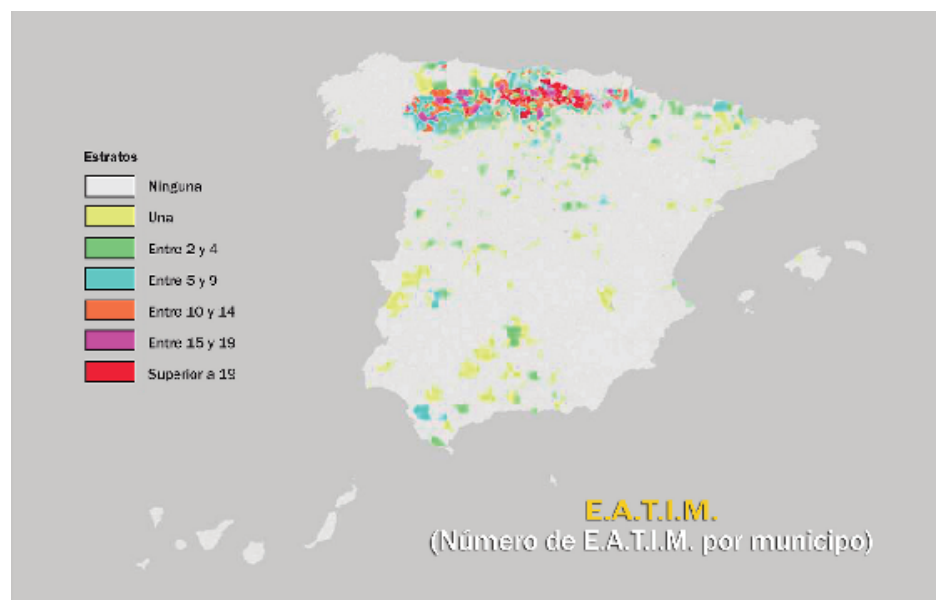

Fuente: Estudio sobre el Registro de las EELL. Ministerio de Política Territorial. Madrid. 2009.

Comparto la opinión de autores como ARNALDO ALCUBILLA que señalan que la escasa atención doctrinal hacia las ELM "no se corresponde a su vigoroso desarrollo en todo el territorio español, aunque sobremanera en la Comunidad Autónoma de Castilla y León en la que se integran más del 70\% de las tres mil cien ELM, lo que acredita su consolidación y raigambre como forma de organización local idónea para los núcleos de población diferenciados del propio municipio del que dependen y se integran", no sé si mi opinión iría a calificar, como dice el autor, de figura "idónea" pero creo que sí necesaria sobre todo en una CA tan dispersa geográficamente y con tan poca densidad de población como es Castilla y León.

\footnotetext{
${ }^{144}$ BELLO PAREDES, S. op cit. Pág. 351: “esta cláusula genérica, sin duda con un importante efecto expansivo, pues hace referencia a un conjunto de diversas entidades como pueden ser las comarcas, las mancomunidades y las EATIM, tiene una importancia acusada por cuanto dota a la diversa tipología de "entidades locales" de los principios de "autonomía, suficiencia financiera, competencia, coordinación, cooperación, responsabilidad, subsidiariedad y lealtad institucional”. "[...] dado el número de entidades locales existentes en Castilla y León, esta regulación estatutaria supone un exceso de asunción de responsabilidades de carácter económico que puede resultar ciertamente insostenible, hasta el punto de poder constituir éste un auténtico "hecho referencial" de nuestra Comunidad Autónoma en relación con el resto de Comunidades Autónomas".
} 


\section{2.- La regulación autonómica en Castilla y León de las ELM}

\subsection{1.- Antecedentes en la legislación autonómica de Castilla y León}

Dentro de la etapa democrática y constitucional de regulación de nuestras AAPP, podemos citar como antecedentes normativos en nuestra región los siguientes:

1.- Decreto 110/1984, de 27 de septiembre para el fomento de las Mancomunidades Municipales, por el cual y ante la apreciación del problema de la planta municipal, se produce una regulación sobre las Mancomunidades Municipales anticipándose a muchas otras CCAA. Siendo conscientes, como he dicho, del problema existente derivado de la proliferación de municipios en este territorio y la escasa capacidad de recursos de que disponen para poder llevar a cabo una prestación de servicios adecuada y de calidad, se optó por la búsqueda de fórmulas asociativas voluntarias, fomentando con esta norma la creación de mancomunidades.

Pero siguiendo al CALONGE VELAZQUEZ, “el Ejecutivo castellano y leonés no se limitó a regular y fomentar esta figura de entidad local, sino que hizo un desarrollo tan completo y exhaustivo que por una parte, según el dictamen del Consejo de Estado, invadía competencias del Estado y por otra chocaba con el principio de autonomía local $^{145,}$.

En cuanto al fomento de estas entidades, en este Decreto 114/1984 se regulaba la cooperación que la Junta de Castilla y León con las entidades locales. Después tras la promulgación de la Ley 6/1986 de 6 de junio, de Relaciones de la Comunidad de Castilla y León con las Entidades locales, se creaba el "Fondo de Cooperación Local", siendo el último Decreto regulador el 53/2002, pero en dicha norma no hay espacio para las ELM, nada se regula respecto de ellas.

\footnotetext{
${ }^{145}$ Vid. "La planta municipal y las entidades locales menores en Castilla y León” en Revista de estudios locales y autonómicos, $n^{\circ}$ 285. 2011, CALONGE VELAZQUEZ, pág. 150. "El régimen orgánico y funcional de las Mancomunidades municipales regulados en este Decreto, que, además, según establece su artículo 2, forma parte del contenido obligatorio de los Estatutos de las mancomunidades que se crearan, es poco compatible con el principio de autonomía municipal, pues introduce una norma interpuesta entre las condiciones mínimas legalmente exigidas y la voluntad intermunicipal que se plasma en los Estatutos. Y además invade las competencias estatales, ya que entra a regular la composición y funcionamiento de los órganos de estos entes, interfiriendo de este modo el régimen jurídico de las Administraciones Públicas que, como es sabido, es competencia exclusiva del Estado".
} 
2.- El proyecto de ley municipal de Castilla y León.

El BOCYL n ${ }^{o} 230$ de 15 de febrero de 1995 recogía el primer intento de regulación de la estructura territorial municipal de la Comunidad de Castilla y León, al publicar el "proyecto de Ley Municipal” que no llegó a ser promulgado.

Pretendía este texto no solo asentar el desarrollo legislativo de las bases en materia de régimen local, sino también lograr un ordenamiento local integrado y obtener una racionalización en las Administraciones Públicas. En su Exposición de Motivos se recoge la preocupación por la estructura municipal de esta comunidad y se proponía el fomento de la integración de los municipios así como la supresión de algunos. Si bien esto sería muy difícil de encarar ya fuera por la distancia y dispersión de algunos núcleos, por la falta de conciencia de los propios entes municipales y sobre todo por su oposición a dejar de existir como administración propia. Por ello, al final, la norma aboga por la promoción del asociacionismo a través de las mancomunidades como solución para paliar el problema.

Dicho proyecto regulaba también a las ELM, denominándolas “Comunidades vecinales" para con ese nombre dignificar sus características institucionales. Venían reguladas en el Título VI y su regulación apenas se aparta de lo previsto por el legislador estatal en los artículos 45 LRBRL, art. 38 a 45 TRRL y 40 a 50 RP que hemos visto. Se les atribuye la consideración de entidad local, personalidad jurídica para el ejercicio de sus competencias y las potestades administrativas recogidas en el art. 4.1 LBRL, con excepción de la potestad de expropiación forzosa, que solo la detentarán en el caso de ejercicio de competencias delegadas por el municipios de que dependen y siempre previa ratificación de sus acuerdos por el Ayuntamiento. Además se las define como aquellos núcleos de población que, en el término municipal, estén separados de aquél donde radique la capitalidad y cuenten con características específicas dentro del municipio.

Las competencias se clasificaban en propias y delegadas. Apenas hay diferencias con lo previsto en la regulación estatal. Como competencias propias estarían la administración y conservación de su patrimonio, incluido el forestal, y la regulación del aprovechamiento de sus bienes comunales. También la de vigilancia, conservación y limpieza de vías urbanas, caminos rurales, fuentes, lavaderos y abrevaderos. Las 
delegadas recaerán sobre la ejecución de obras y la prestación de servicios que sean de su exclusivo interés, prohibiéndose la delegación de las competencias municipales relativas a ordenación, gestión y disciplina urbanística.

\subsection{2.- Régimen jurídico actual}

Respecto de los preceptos básicos vistos anteriormente, éstos fueron desarrollados en el ámbito autonómico en dos vertientes, al asumir las legislaciones autonómicas la regulación normativa de esta entidades, en palabras de SUAREZ OJEDA $^{146}$ : de una manera por las CCAA que tienen legislación específica y de otra por aquellas que han integrado la regulación de estas entidades en el conjunto de la legislación local abordada de modo global. Así, respecto del primer grupo, tienen legislación específica: Aragón (Ley 7/2009 de Concejos Abiertos); Asturias (Ley 11/1986 de reconocimiento de personalidad de la parroquia rural), Cantabria (Ley 6/1994 reguladora de las ELM), Galicia (Ley 11/1983 de parroquias rurales), Extremadura (Ley 17/2010 de mancomunidades y ELM) y Valencia (Decreto 141/2010 por el que se regulan determinados aspectos de la constitución de Comisiones Gestoras y Juntas Vecinales en las ELM). Respecto de la comunidad autónoma de Castilla y León la incardinaría dentro del segundo grupo, donde está el resto de CCAA, las que han optado por regular estas entidades dentro de normativa de régimen local: Andalucía (Ley 5/2010 de autonomía local), Aragón (Ley 7/1999 de administración local), Cataluña (Decreto Legislativo 2/2003 por el que se aprueba la ley municipal y de régimen local), Islas Baleares (Ley 20/2006 de régimen local), Madrid (Ley 2/2003 de administración local), Murcia (Ley 6/1988 de régimen local), Navarra (Ley 6/1990 de administración local).

En consecuencia, las CCAA han mantenido la tradición de la existencia de estas ELM juntamente con las peculiaridades de cada territorio, tras la superación del modelo centralista anterior, pero como se ve, si bien la legislación autonómica ha sido profusa, no parece que se haya alcanzado verdaderamente una regulación adecuada o esperada. El Estatuto de Autonomía de Castilla y León, recoge en su artículo 49 llamado

146 SUAREZ OJEDA, M. “Las entidades locales menores: ¿menores de edad democrática?” Liber Amicorum Tomas Ramón Fernández. 2012. Pág. 81. 
"Regulación del gobierno y la administración local de Castilla y León" lo siguiente respecto de la existencia de las ELM: "En el marco de la legislación básica del Estado y del presente Estatuto, la Comunidad Autónoma establecerá por ley de Cortes la regulación del gobierno y la administración local de Castilla y León. En dicha regulación se contemplarán las entidades locales menores, así como las comarcas, áreas metropolitanas, mancomunidades, consorcios y otras agrupaciones de entidades locales de carácter funcional y fines específicos $[\ldots]$ ”.

Asimismo la Ley 1/1998, de 4 de junio de régimen local de Castilla y León, regula el régimen jurídico de estas entidades en los art. 49 a 71 , y en ellos se definen como entidades locales menores aquellas entidades de ámbito territorial inferior al municipio que, bajo diversas denominaciones tienen reconocido dicho carácter y las que se puedan crear en lo sucesivo, cumpliendo ciertos requisitos ${ }^{147}$. Dicha legislación les atribuye personalidad y capacidad jurídica plena para el ejercicio de sus competencias y son a todas luces entidades locales.

Si analizamos las Leyes autonómicas de Régimen Local, en la mayoría solo se contempla un tipo de ente local de núcleo de población separado de la capitalidad del Municipio, es decir lo que la Ley de Bases define como Entidad de Ámbito Territorial Inferior al Municipio que adquieren distintas denominaciones en las diversas Comunidades Autónomas, aunque en una mayoría, mantienen el antiguo término de Entidad Local Menor ${ }^{148}$. Ni tan siquiera la Ley 8/2010, de 23 de junio, de la

\footnotetext{
${ }^{147}$ Vid. BULLEJOS CALVO, C. "Comunidad política y autonomía local en Andalucía en el contexto del estado de las autonomías", El Consultor de los Ayuntamientos y Juzgados, $n^{\circ}$ 18. Pág. 2031, tomo 2. Madrid 2012: "De esta manera la cuestión referente a la administración del territorio municipal compete en exclusiva a la gobernanza municipal, inhibiéndose la Comunidad Autónoma de cualquier intervención en la creación de entidades descentralizadas".
}

${ }^{148}$ En Navarra se llaman "concejos", y son entidades locales enclavadas en el término municipal con población y ámbito territorial inferiores al de este con bienes propios y personalidad jurídica para la gestión y administración de sus intereses en el ámbito de las competencias atribuidas a los mismos por la ley. Para entender mejor esta estructura, RAZQUIN LIZARRAGA, J.A. "La competencia de los concejos navarros en materia de planeamiento urbanístico". Revista jurídica de Navarra, $n^{\circ}$ 1. Pp. 35-56. 1986 dice: "La especial estructuración de las entidades locales en Navarra permite distinguir entre los denominados municipios simples y los municipios compuestos, estando caracterizados los primeros por la existencia en su territorio de una única institución con jurisdicción total y plena, el Ayuntamiento; mientras que en los segundos, junto al Ayuntamiento con jurisdicción en todo el término municipal, pero no plena o absoluta, existen otros entes, los Concejos, que tienen competencia en parte del término municipal, el término concejil. En el País Vasco y más concretamente en Álava, también reciben esa denominación de concejos (Ley Foral 11/1995) 
Generalitat, de Régimen Local de la Comunidad Valenciana, publicada en su Boletín Oficial el mismo día que la LAULA, ha evolucionado en cuanto a la denominación, manteniendo la existente desde el Estatuto Municipal de 1924, y tampoco contempla otra realidad rural más que las Entidades Locales Menores. Solamente la Comunidad Aragonesa diferencia a las Entidades Locales Menores de otros núcleos de población, denominados históricamente Comunidades de Villa y Tierra, siendo consideradas, también, como Entes Locales y la Navarra que incluye como Entidades Locales a La Comunidad de Bardenas Reales de Navarra, la Comunidad del Valle de Aezcoa, la Mancomunidad del Valle de Roncal, la Universidad del Valle de Salazar y el resto de corporaciones de carácter tradicional, titulares o administradoras de bienes comunales existentes a la entrada en vigor de la Ley Foral.

Destaca en la normativa de Andalucía la regulación de dos tipos de entidades: las "entidades vecinales": que son entidades para la gestión descentralizada de servicios locales de interés general y ejecución de obras de la competencia municipal que asumen por delegación del Ayuntamiento, y que se ha definido como un nuevo fenómeno de descentralización territorial ya que no se las prevé un marco competencial propio por la ley) y las "entidades locales autónomas" (ELAS): que son entidades creadas para el gobierno y administración de sus propios intereses diferenciados de los generales del municipio, a cuyo efecto ostentan la titularidad de competencias propias y las que puedan ser transferidas por el Ayuntamiento ${ }^{149}$.

149 VV.AA. Memento Práctico Administración Local. Editorial Francis Lefevbre. 2011. Madrid. Pág. 516: Un sector de la doctrina entendía que las antiguas Entidades Locales Menores una vez aprobada la LRBRL, se llamaban Entidades Territoriales de Ámbito Territorial Inferior al Municipio (EATIM) y que ahora esta Comunidad Autónoma las pasaba a denominar Entidades Locales Autónomas. No era sino distintas formas de llamar a los núcleos separados del Municipio para la gestión descentralizada de la administración de sus intereses. Esta doctrina, chocaba con otra que mantenía que las Entidades Locales Autónomas (ELA) eran otros entes diferenciados de las EATIM, por lo que para alcanzar el régimen de ELA, era necesario que la EATIM se sometiera a un procedimiento de adaptación. Esta tesis se basaba en la Disposición Transitoria Segunda de la LDMA que encomendaba a la Consejería de Gobernación la regulación del proceso de adaptación de las EATIM en ELA.

Aunque el párrafo segundo de la citada Disposición Transitoria Segunda parecía contradecir dicha tesis, puesto que reconocía la existencia de ELAS con anterioridad a la entrada en vigor de la Ley, y se disponía el mantenimiento del nivel de competencias y recursos de las mismas, si éste fuese en algún aspecto superior al contemplado en esta Ley. Finalmente la Orden de la Consejería de Gobernación de 13 de junio de 1997 se decantó por el criterio de la segunda línea doctrinal, regulando un procedimiento de adaptación de las EATIM al régimen de las Entidades Locales Autónomas. Por su parte el Decreto 185/2005, de 30 de agosto, Reglamento de Demarcación Municipal de Andalucía y del Registro Andaluz 
En Asturias existe la llamada parroquia rural ${ }^{150}$, definida como una entidad local inframunicipal con personalidad jurídica propia como forma tradicional de convivencia. ${ }^{151}$ En Galicia existe la figura también de la parroquia que si bien es una

de Entidades Locales, (RDMA) incorporó el citado procedimiento de adaptación en su Capítulo V del Título III, arts. 77 a 81.

Pero tanto la Orden referida como el Decreto fueron recurridos ante el TSJ de Andalucía por la Federación Andaluza de Entidades Locales y por algunas entidades concretas que entendían que ambas disposiciones se extralimitaban en el desarrollo normativo de la Ley. Así las cosas el TSJ anula en sentencias de 22 de mayo de 2000, de 4 de febrero de 2002 y 15 de marzo de 2002 la citada Orden, y posteriormente en sentencia de 14 de abril de 2008 y 3 de mayo de 2010 parte del articulado del Reglamento entre ellos los art. 77 a 81 citados, justificándose en la extralimitación respecto de la ley.

El TSJ mantiene que las ELA no son otras diferentes que las EATIM y que "el proceso de adaptación a que se refería la Ley solo puede referirse a cuestiones formales de cambio de denominación, inscripción correspondiente etc...".

${ }^{150}$ CORRIPIO RIVERO, M. op cit. pág. 324: "el modelo territorial diseñado para Asturias, que elimina las entidades locales menores u crea un nuevo ente inframunicipal con personalidad jurídica que titula Parroquia, conservando así el nombre de una de las entidades locales menores, pero modificando su personalidad y figura jurídica. Como consecuencia de lo anterior surgen dos problemas: a) que hacer con las entidades locales menores existentes y b) redefinir qué sea la Parroquia. [...] se resuelve el dilema de la siguiente forma: hace un claro distingo entre Parroquias y Entidades Locales Menores; y en la Disposición Transitoria Primera, se concede un plazo de 2 años a las entidades locales menores existentes para convertirse en Parroquias rurales, trascurrido el cual sin haberse efectuado la reconversión, el Consejo de Gobierno adoptará bien la disolución de la entidad local menor o bien su conversión en Parroquia pero capitis disminuida con exclusión del régimen de ayudas especiales.

151 TOLIVAR ALAS, L "La descentralización municipal: las parroquias asturianas". Documentación Administrativa, $n^{\circ}$ 228. 1991. pág. 138: "El origen de esta estructura parroquial suele situarse en las gentilitates o comunidades gentilitas que, mantenidas por las dominaciones romana y visigoda, fueron transformadas por el cristianismo en demarcaciones territoriales. Se rigieron hasta los siglos XVII o XVIII, según los lugares, por costumbres de transmisión oral. La estructura parroquial, históricamente vinculada al Concejo abierto, quedo como una reliquia del pasado tras la modernización institucional traída por nuestro primer constitucionalismo. Su presencia fáctica perduró en caso toda la cornisa cantábrica, pese al significativo silencio de textos como el Estatuto de Cantabria que no acertó a recuperar el valor diferencial de su territorio, saturad de entidades inframunicipales. Tal es, también, el caso del Estatuto de CASTILLA Y LEON que en este como en otros aspectos culturales, muestra un uniformismo ciertamente ofensivo, por sus olvidos, hacia el norte de la comunidad, y muy singularmente hacia la provincia de LEON". Vid. GARCIA ALVAREZ, B. "Monografia sobre los concejos de parroquias y feligresías de Asturias". Historia de la Administración Local. Madrid, 1954. "La parroquia española surge espontáneamente en el pueblo, a lo sumo es la Iglesia quien designa titular, en algunos casos a propuesta del pueblo mismo". Vid. CORRIPIO RIVERO, M. "La parroquia". Congreso jurídico de Asturias. Academia Asturiana de Jurisprudencia. Oviedo. 1987. pp. 321-328. "Se observa y es de destacarse, que el núcleo de población llamado parroquia, capaz de alcanzar la personalidad jurídica de entidad local menor, es comprendido dentro de un mayor o menor núcleo de población, sin diferenciación de las diversas regiones a lo lardo de la legislación contemplada; pero que una vez reducido a las legislaciones autonómicas, tanto en Galicia como en Asturias, se individualiza y se pretende hacer de la Parroquia un signo característico de esos territorios". Vid. GOMEZ PELLON, E. "Los concejos abiertos parroquiales asturianos. El caso del oriente asturiano". Libro I Congreso Jurídico de Asturias, Oviedo 1987. MACEDA RUBIO, A. "La ordenación histórica del espacio en la parroquia de Arenas de Cabrales a través de sus ordenanzas" Eria, 75. 2008. 
unidad territorial inferior al municipio, no está reconocida jurídicamente, pero ha desempeñado un papel importantísimo y reconocido de hecho aunque no de derecho. ${ }^{152}$

Para terminar de enmarcar el contexto del ordenamiento jurídico castellano leonés,

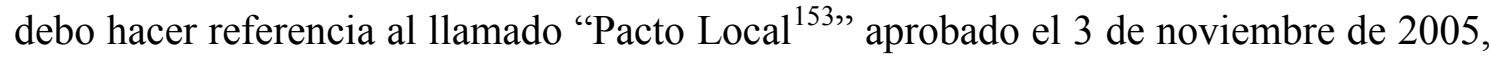
concebido como un "proceso dinámico para la creación de un nuevo marco de relaciones entre la Comunidad Autónoma y las Corporaciones Locales y el refuerzo de los poderes locales”, que derivó en una serie de ayudas económicas que en nada tuvieron en cuenta a las entidades locales menores.

\section{3.- Competencias y Potestades}

Como acabamos de ver y continuando con la regulación de la Ley 1/1998, ésta reconoce de manera expresa las competencias y potestades de estas entidades. Dentro de las primeras se mencionan:

- La administración y conservación de su patrimonio, incluido el forestal, y la regulación del aprovechamiento de sus bienes comunales ${ }^{154}$; que es una de las

\footnotetext{
${ }^{152}$ En el art. 1.2 se recoge la siguiente afirmación: "En los términos que determinará una Ley del Parlamento de Galicia, las parroquias rurales gallegas tendrán la consideración de Entidades Locales territoriales y gozarán de autonomía para la gestión de sus intereses patrimoniales", y el art. 2.1 modificado por la Ley 4/2012, de 12 de abril del Área Metropolitana de Vigo, afirma que "disfrutan de la condición de entidades locales no territoriales las mancomunidades de municipios, los consorcios locales y las entidades locales menores". Llama poderosamente la atención que la propia ley de régimen local gallega reconozca carácter de entidad territorial a la parroquia, entidad que a fecha de hoy no ha sido aprobada la ley que la regule, pero no se reconoce dicha naturaleza a la entidad local menor. Lo que sí se aprobó fue la Ley 11/1983 de 29 de diciembre de Actuación intensiva en las parroquias rurales, entendiéndose por actuación intensiva el conjunto de acciones e inversiones previamente estudiadas para aplicación en cada parroquia rural, teniendo en cuenta sus peculiaridades. Se han constituido nueve entidades locales menores de más de 3.700 parroquias rurales que existen. Así dice LISON TOLIVAR, C. “Límites simbólicos. Apuntes sobre la parroquia rural” Revista española de opinión pública. Marzo 1969, pág. 110, que el promedio de parroquias por municipio es de 11 en números redondos.
}

${ }^{153}$ Vid. FERNANDEZ DE GATTA SANCHEZ, D. "El régimen jurídico de las Comunidades de Villa y Tierra: aspectos históricos y régimen vigente" Revista jurídica de Castilla y León $n^{o}$ 21. 2010; QUINTANA LOPEZ, T. "Algunas cuestiones sobre la vertebración administrativa”. Revista Jurídica de Castilla y León, núm. Extraordinario, 2006, pp. 317 y ss.

154 En Andalucía, la Ley 5/2010 ha eliminado del listado de competencias de las ELA la de regulación del aprovechamiento de sus bienes comunales, si bien hay que indicar que el art. 38 TRRL la establece, 
piezas capitales de la existencia de estos entes y como veremos, foco de numerosísimos problemas.

- La vigilancia, conservación y limpieza de vías urbanas, caminos rurales, fuentes, lavaderos y abrevaderos.

- Asimismo podrán ejecutar las obras y prestar los servicios que les delegue expresamente el Ayuntamiento $^{155}$. Pero existe un límite importante y que es que no serán delegables las competencias municipales relativas a ordenación, gestión y disciplina urbanística.

El ejercicio por las ELM de sus competencias propias o delegadas estará limitado al ámbito de su territorio. Como podemos ver, y a diferencia de otras CCAA, en la legislación castellano leonesa no se le atribuyen a las ELM competencia alguna en materia de urbanismo ${ }^{156}$.

teniendo carácter supletorio. En Cataluña se recoge como competencias no previstas en Castilla y León la de alumbrado público, y la de ordenación del tráfico de vehículos y de personas en su ámbito. En Murcia se atribuyen de manera expresa a las ELM las competencias de policía urbana, ordenación del tráfico, agua, alumbrado, recogida de basuras, protección civil y actividades culturales y sociales, un ambicioso catálogo de competencias que desde luego no responde para nada con la mentalidad de racionalización de no duplicidad competencial. En Navarra destaca la asignación de la competencia de conservación y mantenimiento de cementerios a las ELM, si bien el Informe especial al Parlamento de Navarra del Defensor del Pueblo de Navarra de septiembre de 2008 pone de manifiesto las carencias y dificultades para ejercer con eficacia las funciones legales encomendadas a los concejos y propone que las competencias vinculadas con servicios locales se ejerzan por los municipios, y que se circunscriba a su ámbito competencial más a la gestión del patrimonio, a la gestión del archivo concejil y a la organización de sus fiestas locales.

${ }^{155}$ Dicha delegación requerirá para su efectividad la aceptación de la ELM, debiendo especificarse en el acuerdo de delegación las formas de control propias de esta figura que se reserve el ayuntamiento delegante y los medios que se pongan a disposición de aquella.

${ }^{156}$ En Aragón sí se recoge la competencia de otorgamiento de licencias de obras cuando el municipio cuente con planeamiento aprobado. A tal efecto es indicativa la referencia hecha por RODRIGUEZ CATIVIELA, V. op cit. pág. 448 de que las competencias actualmente se revelan como insuficientes, habiéndose producido una ampliación de las mismas por vía jurisprudencial, y destaca la sentencia STS de 27 de enero de 1986 que les atribuye competencias en materia urbanística: "excluidos planes generales, todos los demás concretamente los parciales y especiales, así como los estudios de detalle y los proyectos de urbanización pueden ser promovidos, redactados y tramitados por las entidades locales menores, siempre y cuando los efectos de ellos no traspasen los límites territoriales a que extiende su competencia o afecten a las líneas generales obligatorias dimanantes del Plan General, o que significa que tales entidades locales menores tienen competencia para la aprobación provisional". En Baleares se recoge también la posibilidad de concesión de licencias de obras menores por parte de las ELM y como significativo la posibilidad de que constituyan archivos locales. En Navarra sí se reconoce también la competencia de otorgamiento de licencias urbanísticas conforme al planeamiento y previo informe preceptivo y vinculante del ayuntamiento. Es reseñable la STS de 27 de septiembre de 1985 que niega competencias en materia de planeamiento urbanístico a los concejos. En Álava también se reconoce la capacidad de participación en el proceso urbanístico, dentro de la legalidad vigente. La capacidad de participación de los concejos en el proceso urbanístico se reconoce dentro de la legislación vigente, y dicha legislación atribuye a los ayuntamientos la competencia en materia de planeamiento municipal; se garantiza a los concejos un derecho de participación pero no la capacidad de veto o decisión; no se trata 
En cuanto a las potestades reconocidas para poder realizar las competencias asignadas, se dispone que sean:

- La potestad reglamentaria ${ }^{157}$ y de autoorganización.

- El establecimiento de tasas, precio públicos y contribuciones especiales.

- La potestad de programación o planificación.

- La potestad de investigación, deslinde y recuperación de oficio de sus bienes.

- La presunción de legitimidad y la ejecutividad de sus actos.

- La potestad de ejecución forzosa y sancionadora.

- La potestad de revisión de oficio de sus actos y acuerdos.

- La inembargabilidad de sus bienes y derechos en los términos previstos en las leyes; las prelaciones y demás prerrogativas reconocidas a la Hacienda Pública para los créditos de la misma, sin perjuicio de os que correspondan a las Haciendas del Estado, de la Comunidad Autónoma y de los municipios.

Reconociendo a su vez que si actúan por delegación del municipio ostentarán además la potestad expropiatoria, pero no reconociendo esta potestad de manera expresa, al igual que ocurre en la regulación de Andalucía, donde la no inclusión en la LAULA de la potestad expropiatoria para las ELA, y al no haberse previsto tampoco en el TRRL, parecer que dicha ley ha querido reservarla a los ayuntamientos, no considerando su descentralización por los importantes efectos jurídicos que implican ${ }^{158}$.

de introducir en el procedimiento para la elaboración de los planes un nuevo trámite a fin de que tales entidades informen de forma preceptiva, de tal manera que cuando no se les dé un traslado singular y específico para su intervención, el resultado sea la nulidad de tales normas de planeamiento municipal (TSJ País Vasco 14 de julio de 2005; 11 de mayo de 2007). Se considera que esta participación se ha cumplido si se ha participado en el proceso de elaboración del planeamiento dentro de los periodos de información pública habilitados a tal efecto y mediante las reuniones con los responsables técnicos y políticos del ayuntamiento (TSJ País Vasco 11 de mayo de 2007).

${ }^{157}$ Donde podemos encontrar más ejemplos de ejercicio de la potestad reglamentaria de las ELM es con relación a ordenanzas fiscales y la gestión del servicio de abastecimiento de agua, que regulan la tasa por dicho servicio. Si bien a priori puede resultar excesivo que tales entidades gocen del poder reglamentario, sin embargo en aquellas supuestos donde actúan por delegación municipal en la gestión de servicios, tales como el agua, o en la realización de obras, es una buena previsión que estas entidades gocen de tal potestad que les permita desempeñar estos cometidos de un modo más eficiente.

${ }^{158}$ Esta eliminación de la potestad expropiatoria, queda, de nuevo, patente si analizamos también el art. 122.2 LAULA, el cual no incluye entre los acuerdos a ratificar por el Ayuntamiento, los acuerdos de expropiación forzosa. Inclusión que si hacía la derogada LDMA, y que también hace el art. 45.2 c) LRBRL.

En este sentido, el sometimiento a ratificación municipal de los acuerdos de expropiaciones forzosas que adopten las ELAS establecido por la LRBRL, en su art. $45.2 \mathrm{c}$ ), tiene naturaleza de norma básica, tal 
Se recoge en esta ley la limitación, también existente en el resto de regulaciones autonómicas $^{159}$, referida a que los acuerdos que se adopten sobre disposición de bienes, operaciones de crédito y expropiación forzosa, deberán ser ratificados por el ayuntamiento para ser ejecutivos ${ }^{160}$. Como hecho diferenciador he comprobado que la regulación que hace la legislación andaluza del régimen de autorización previa municipal para los acuerdos de las ELAS relativos a las plantillas de puestos de trabajo, las relaciones de puestos de trabajo y ofertas de empleo público, es un aspecto que no he encontrado regulado en otras CCAA.

Como ya se ha mencionado, una de las razones de ser y de existencia de estas entidades es la necesidad misma de gestionar su propio patrimonio. De esta trascendental competencia llama la atención que el legislador autonómico quiso poner de relieve al prever que, posteriormente mediante el correspondiente desarrollo reglamentario, se determinará el régimen de colaboración de la comunidad autónoma con las Diputaciones Provinciales para que éstas pudieran en marcha un "servicio de gestión del Patrimonio de las ELM". Dicho desarrollo normativo no se ha efectuado y entendemos que no puede quedar sustituido por el conjunto de ayudas derivadas del Pacto Local y otorgadas a las Diputaciones, como veremos más adelante.

como fue corroborado por la ya comentada sentencia TC de 21-12-1989, por lo que podría ser cuestionada la posibilidad de que la norma autonómica no atribuya la potestad.

No obstante, puede entenderse que la prevención del art. 45.2 c) es para el supuesto de que la norma autonómica atribuya la potestad expropiatoria a las ELAS, que no es el caso de la LAULA.

${ }^{159}$ En la regulación prevista en Cataluña se establece un plazo de dos meses para proceder por parte del municipio a la ratificación de los acuerdos sobre dichas materias, y en concreto, y con relación a la expropiación forzosa, y como dice PALLARES SERRANO, A. ob cit pág. 139: "Esta realizad legislativa responde a la consideración de que solo los entes territoriales de existencia obligatoria se pueden considerar como ente primarios y son estos a los que de manera originaria corresponde la atribución de las respectivas potestades administrativas".

${ }^{160}$ TOLIVAR ALAS, L. op cit. pág. 120: El TC afirma que la fórmula aprobatoria recogida en el art. 45 LBRL referida a que los acuerdos de disposición de bienes, operaciones de crédito y expropiación forzosa deberán ser ratificados por el Ayuntamiento, en nada lesiona la competencia de la Comunidad Autónoma de Galicia, [...] ya que se trata de entidades que, aun cuando aparezcan dotadas de personalidad jurídica, no dejan de formar parte de la entidad municipal, actuando en un régimen de descentralización que, si bien a la legislación autonómica corresponderá precisar, justifica que, como garantía misma de la institución municipal, el legislador estatal le atribuya a ésta una cierta facultad de tutela. Facultad de tutela referida a un catálogo tasado de supuestos de incuestionable relieve para el propio municipio, lo que, por ello mismo, no coarta indebidamente la competencia de la Comunidad Autónoma de Galicia para establecer, con estos condicionamientos mínimos el régimen jurídico de la parroquia rural”. 


\section{4.- Creación}

La ley establece que los núcleos de población que, en el término municipal, estén separados de aquél donde radique la capitalidad y cuenten con características específicas dentro del municipio podrán constituirse en ELM, para la gestión de sus intereses peculiares y descentralización de la Administración municipal, en los siguientes casos, los cuales no difiere de otras CCAA:

a) Cuando se suprima el municipio a que pertenezcan.

b) Cuando, por alteración de los términos municipales, pasen dichos núcleos a formar parte de otros municipios.

c) Cuando se solicite con arreglo a lo establecido en el procedimiento para la constitución de las mismas.

Y como requisitos se exigen ${ }^{161}$ :

- El conjunto de edificaciones que formen el núcleo estará separado de las restantes del municipio, sin que, en ningún caso, exista continuidad.

- Contar con un territorio y recursos que garanticen el cumplimiento de los fines para los que se cree.

- Existencia de bienes, derechos o intereses peculiares y propios de los vecinos del núcleo, distintos de los comunes al municipio, que puedan justificar la constitución.

- El número mínimo de habitantes y la distancia del núcleo principal que deban darse se determinarán reglamentariamente, desarrollo que para no variar, no se ha llevado a cabo por la CA.

Como límites a la creación de estas entidades (recordamos que estamos hablando de la regulación anterior a la aprobación de la LRSAL, y que la Ley 1/1998 no se ha adaptado a la misma) se recogen: no podrá constituirse en entidad local menor el núcleo

\footnotetext{
161 Además de las diferencias ya vistas en cuanto a la exigencia del número poblacional en las regulaciones de otras CCAA, indicar que en el régimen jurídico de Baleares se exige como requisito para la constitución de una ELM que la misma tenga un mínimo de 50 años de existencia, debidamente acreditado por medios probatorios, requisito que no existe en Castilla y León. En la regulación prevista en La Rioja se permite la constitución de juntas de vecinos como órganos territoriales de participación en los núcleos de población separados de la capitalidad del municipio que no tengan condición de ELM.
} 
donde radique la capitalidad del municipio, ni las urbanizaciones de iniciativa particular y ninguna entidad local menor podrá pertenecer a dos o más municipios.

El procedimiento para constitución de entidades locales menores podrá iniciarse a instancia de los vecinos residentes en el núcleo que lo pretende o del municipio a que el mismo pertenezca. Como diferencia encontrada en otra normativa autonómica quiero destacar la prevista en Andalucía al permitir que ostenten iniciativa en la creación de las ELA entre otros a los Grupos Municipales, novedad absoluta de la LAULA, reconociendo con ello la intervención de los grupos en la organización territorial descentralizada del municipio. Así como otra diferencia reseñable es la aparición en el régimen andaluz del llamado "Instrumento de Creación" y la previsión de la elaboración de unos Estatutos de la entidad, cuyo contenido es fijado en la ley.

En Álava es necesaria la existencia de al menos cuatro unidades foguerales (unidad familiar independiente que mantenga casa abierta ${ }^{162}$ en el concejo durante al menos siete meses al año y alguno de sus componentes esté inscrito en el padrón concejil) que tengan raigambre histórica y que figure en el nomenclátor de los núcleos de población. ${ }^{163}$

\footnotetext{
162 Expongo a continuación algún ejemplo ilustrativo jurisprudencial de los medios de prueba y la importancia que en este territorio tiene el concepto de residencia y morada: "La existencia de una morada y residencia continuada en el lugar puede ser acreditada, en las actuales circunstancias de tiempo y lugar, de manera documental a través de planos, registros civiles, administrativos o fiscales, escrituras, licencias, facturas, entre otros" (TSJ País Vasco 31 de mayo de 2002). El elemento básico del domicilio real o efectiva morada en un lugar preciso y determinado donde el individuo tiene la sede de su existencia familiar y colectiva, integrante de la residencia habitual y sustrato primario de la vecindad, viene caracterizado por la Norma Foral de Álava 11/1995 con el uso de la expresión "casa abierta", equivalente a las otras que son habituales en la materia, tales como "casa con humo", o en el mismo ámbito alavés, "unidad fogueral", que no puede ser suplido por aquella actividad no configuradora de la noción de residencia por el desempeño durante años de una actividad industrial determinada con presencia física continuada en el ámbito de dicha localidad (TSJ País Vasco 31 de mayo de 2002).
}

163 AGIRREAZKUENAGA ZIGORRAGA, I: "La organización de las entidades locales" http://www.iustel.com: "La jurisprudencia, al igual que el Consejo de Estado, insisten en que no existe un derecho subjetivo por parte de un núcleo diferenciado y con características peculiares para erigirse en entidad local menor. De ahí que las entidades locales menores tengan carácter contingente y voluntario. Por lo tanto la resolución definitiva sobre su constitución corresponde al Consejo de Gobierno de la Comunidad Autónoma - STS 16 de enero de 1998-“. 


\section{5.- Organización y funcionamiento}

En Castilla y León, los órganos de gobierno y administración de las entidades locales menores son el Alcalde pedáneo, como órgano unipersonal, y la Junta Vecinal, como órgano colegiado. Ésta estará integrada por el Alcalde pedáneo, que la preside, y por dos o cuatro Vocales, según que el núcleo sea inferior o no a 250 residentes. Los Vocales de la Junta Vecinal serán nombrados por el Alcalde pedáneo.

Si bien se regula una excepción y es que cuando a la alcaldía hubieran concurrido dos o más candidatos, será proclamado Vocal el candidato que hubiera obtenido el segundo lugar en número de votos, prevaleciendo en caso de empate el de menor edad. A estos efectos, la Junta Electoral de Zona proclamará como Vocal de la Junta Vecinal a quien correspondiera de forma directa en virtud de lo dispuesto en el apartado anterior, determinando el número de Vocales que corresponde designar al Alcalde pedáneo. El Alcalde pedáneo podrá cesar en cualquier momento a los Vocales que hubiera nombrado. Los ceses y nombramientos deberán ser comunicados al Ayuntamiento para que surtan efecto. En Álava existe la figura conocida como "fiel de fechos" que nombra el regidor-presidente, y que ejerce las funciones de secretario, tanto de la asamblea vecinal como del a junta administrativa.

En cuanto a la forma de elección de los Alcaldes pedáneos, se lleva a cabo directamente por los vecinos de la correspondiente entidad local menor por sistema mayoritario, mediante la presentación de candidatos por los distintos partidos, federaciones, coaliciones o agrupaciones de electores ${ }^{164}$; y en cada candidatura a Alcalde pedáneo se debe incluir un candidato suplente ${ }^{165}$.

Se prevé la posibilidad de que la ELM pueda funcionar en régimen de Concejo Abierto, y en este caso el gobierno y administración de la misma corresponderá al

\footnotetext{
${ }^{164}$ Para presentar candidatura, las agrupaciones de electores necesitan un número de firmas no inferior al 3 por 100 de los inscritos en el censo electoral, sin que, en ningún caso, el número de firmantes pueda ser inferior a cinco.

${ }^{165}$ En caso de fallecimiento, incapacidad o renuncia del Alcalde pedáneo, será proclamado como tal el suplente de la misma candidatura.
} 
Alcalde pedáneo y a la Asamblea Vecinal, de la que formarán parte todos los electores. Las ELM funcionarán en régimen de Concejo Abierto en los supuestos contemplados en el artículo 72 de esta Ley ${ }^{166}$.

En cuanto a las funciones de los órganos citados, tanto el Alcalde pedáneo como la Junta Vecinal o, en su caso, Asamblea Vecinal, ostentarán las atribuciones que la legislación establezca como propias del Alcalde y del Pleno del Ayuntamiento, respectivamente, limitados al ámbito de competencias de la entidad local menor. El Alcalde pedáneo designará, entre los Vocales de la Junta Vecinal o entre los electores de la Asamblea Vecinal, según cuál sea el régimen de funcionamiento de la entidad local menor, quien deba sustituirle, en los casos y con los efectos previstos en la legislación de Régimen Local. El Alcalde pedáneo, o el Vocal de la Junta Vecinal que él designe, tendrán derecho a asistir, con voz pero sin voto, a las sesiones del Ayuntamiento, siempre que en las mismas haya de debatirse algún asunto que afecte a la entidad local menor. Para el ejercicio de este derecho deberá ser citado a la reunión de la corporación como un miembro más de la misma y tendrá acceso a la documentación necesaria. En cualquier sesión ordinaria a la que asista podrá formular ruego o pregunta sobre asunto que afecte a su entidad local menor.

En el régimen jurídico de Baleares, en concreto en el Decreto 63/2007, de 25 de mayo, modificado por Decreto 105/2010 de Baleares, se regula el sistema de

\footnotetext{
${ }^{166}$ Existe en Aragón el Decreto 14/2011, de 25 de enero, del Gobierno de Aragón, por el que se aprueba la relación definitiva de los municipios y entidades locales menores aragoneses que permanecen en régimen de Concejo Abierto en las elecciones del año 2011 al amparo de la Ley 9/2009, de 22 de diciembre, reguladora de los Concejos Abiertos (que modificó el art. 91.1), y se publica la relación de municipios tradicionales, la de municipios y entidades locales menores de menos de 40 habitantes y la de aquellos con una población de 40 a 99 habitantes que se regirán mediante democracia representativa, pero se dio la circunstancia en dicho año 2011 que se aprobó la Ley Orgánica 2/2011, la cual incide de un modo especial en la normativa propia aragonesa. Vid. PUEYO MOY, J. "La incidencia en los Concejos Abiertos y Entidades Locales Menores de Aragón de la modificación del régimen de Concejo Abierto en la Ley 7/1985, operada por la Ley Orgánica 2/2011, de 28 de enero" Anuario Aragonés del Gobierno Local, 2010 pp. 363-380.. hace la siguiente apreciación sobre el particular: "La nueva redacción del art. 29 LBRL que elimina la obligación de que los municipios se rijan por concejo abierto por razón de su población, choca con la Ley 9/2009 aragonesa, por más que ésta haya reducido el límite poblacional a menos de 40 habitantes, y pone en tela de juicio el Decreto 14/2011....”; “...tomando los datos recogidos en el Anexo III del Decreto 14/2011 [...] resultaría:

- que en la provincia de Huesca, tras la LO 2/2011, ningún municipio estaría sujeto al concejo abierto, frente a los 12 municipios que sí lo estaban anteriormente al no ser ninguno tradicional;

- que en la provincia de Teruel el número de municipios que se continuarán rigiendo por este sistema serían 4;

- que en la provincia de Zaragoza serían 6 municipios. [...]
} 
compensación económica destinado a los ayuntamientos y ELM de Baleares que abonen a sus miembros electos retribuciones por el ejercicio de sus cargos en régimen de dedicación exclusiva al servicio de la gestión pública local ${ }^{167}$, aspecto no regulado en ninguna otra $\mathrm{CA}$.

En cuanto al funcionamiento de las ELM, se establece como periodicidad que la Junta Vecinal celebrará sesiones ordinarias, al menos, cada seis meses y extraordinarias cuando lo decida el Presidente o lo solicite la mayoría de sus miembros. En este último caso, la celebración de la sesión no podrá demorarse por más de un mes desde que fue solicitada. El quórum exigido para la válida constitución de la Junta Vecinal es la asistencia de dos tercios del número legal de miembros de la misma, entre los que ha de contarse necesariamente el Alcalde pedáneo. En algunas de las regulaciones autonómicas se recoge la posibilidad de que las ELM puedan aprobar su propio reglamento orgánico, tal es el caso de Baleares o La Rioja, opción que encuentro positiva a la hora de regular de una manera más específica todo lo relativo a la organización y funcionamiento de estas entidades.

Como novedad esta ley incorpora la opción de que el Alcalde pedáneo puede ser destituido de su cargo mediante moción de censura, como se ha visto anteriormente, la cual deberá ser suscrita y aprobada, al menos, por la mayoría absoluta de los electores. La moción debe incluir el nombre del candidato propuesto para Alcalde pedáneo y el del suplente, quedando proclamado aquél en caso de que prospere la moción. La moción debe ser discutida y votada en el plazo de quince días desde su presentación en una sesión o asamblea convocada al efecto. Todos los electores pueden ser candidatos y ninguno de ellos puede suscribir durante su mandato más de una moción de censura.

En cuanto a los conflictos de competencias que se susciten entre entidades locales menores pertenecientes a un mismo municipio serán resueltos por el

\footnotetext{
${ }^{167}$ A estos efectos se exige:

- que la población de la ELM no supere los 5.000 habitantes conforme a las últimas cifras de población publicadas por el organismo competente.

- que la totalidad de recursos ordinarios del presupuesto general de la entidad no supere la cifra de 3.000.000 euros de acuerdo con los datos del presupuesto del año anterior definitivamente aprobado por la entidad local.

- que la cifra global de retribuciones, indemnizaciones y asistencias que prevea abonar la entidad ocal en la anualidad de la solicitud, al resto de sus miembros electos, no supere el importe de compensación solicitada.
} 
Ayuntamiento de éste. En los demás casos, resolverá la Consejería competente en materia de Administración Local, previo informe, en todo caso, de los Ayuntamientos y Diputación o Diputaciones Provinciales afectados.

Por último se recoge que las ELM responderán directamente de los daños y perjuicios causados a los particulares en sus bienes y derechos como consecuencia del funcionamiento de los servicios públicos o de la actuación de sus autoridades, funcionarios o agentes, en los términos establecidos en la legislación general sobre responsabilidad administrativa. Como ejemplos de la posibilidad de exigir responsabilidad patrimonial a las entidades locales menores podemos citar la Sentencia del TSJ de Castilla y León (Valladolid), Sala de lo Contencioso Administrativo, de 21 de Junio de 2007, rec. 1698/2001, donde se puede ver uno de los supuestos más frecuentes en la casuística de la exigencia de responsabilidad a una Junta Vecinal, en este caso, titular de un Coto de Caza, y los daños producidos por una pieza de caza en accidente de tráfico, donde se analiza un supuesto de responsabilidad objetiva con condena, basándose en la legislación vigente en dicho momento, de la Junta Vecinal. O este otro caso recogido en la Sentencia del TSJ de Cantabria, Sala de lo Contencioso administrativo, Sentencia 14 Nov. 2000, rec. 433/1999, donde debido a la limpieza de caminos y actividades de quema de la maleza, llevada a cabo por vecinos pero actuando estos por indicación de la Junta Vecinal, constando a tal efecto acuerdo de la misma para realizar dichos trabajos por los vecinos, e incluso autorización del SEPRONA, se produjeron daños en una finca particular, consistentes en quema de varios árboles, el estacado de la finca y el talud, por todo lo cual el afectado solicitaba responsabilidad patrimonial de la Junta Vecinal ante la desestimación presunta por silencio administrativo. La cuestión principal era , ¿debe la Junta Vecinal demandada responder de esos daños causados por los vecinos que actuaron en virtud de autorización de la misma?. La competencia de limpieza de caminos corresponde a las Juntas Vecinales, y en este caso y ante la insuficiencia de medios, dicha limpieza se venía realizando por los vecinos con la autorización del ICONA. Por lo tanto los vecinos estaban actuando como agentes de la Junta Vecinal, no es una actuación privada de los mismos, en cuyo caso responderían personalmente, sino que actúan como parte de la Junta Vecinal. 


\section{6.- Recursos económicos}

La hacienda de las ELM estará constituida por los siguientes recursos:

a) Ingresos procedentes de su patrimonio y demás de Derecho privado.

b) Tasas y precios públicos.

c) Contribuciones especiales.

d) Subvenciones y otros ingresos de Derecho público.

e) Ingresos procedentes de operaciones de crédito.

f) Multas.

g) Aportaciones municipales y participaciones en los ingresos del municipio, de conformidad con lo establecido en los artículos siguientes.

Las entidades locales menores podrán imponer la prestación personal y de transporte, salvo cuando la tuviera acordada el Ayuntamiento con carácter general, lo cual es una fuente de ingresos muy interesante y muy característica de la vida rural y la vinculación de los vecinos con su pueblo ${ }^{168}$.

Los Ayuntamientos garantizarán para las ELM integradas en el municipio los ingresos mínimos necesarios para el cumplimiento de sus funciones y el ejercicio de sus competencias $^{169}$. Los Ayuntamientos, no obstante, podrán suspender dicha aportación si la entidad local no aplicara en su término tasas o precios públicos que sí se aplicaran en

\footnotetext{
168 Como supuesto llamativo quisiera hacer referencia a la figura prevista en la legislación asturiana de la sextaferia: figura del derecho consuetudinario consistente en la prestación personal de carácter obligatorio para desarrollar trabajos comunales destinados a la apertura, construcción, reconstrucción, conservación, reparación, mantenimiento, arreglo, limpieza y mejora de caminos vecinales, fuentes, abrevaderos, lavaderos, puentes, suministro de agua, en su caso, y demás infraestructuras similares localizadas en el pueblo y en sus espacios productivos, de interés exclusivo para sus vecinos. La obligatoriedad de acudir a la sextaferia alcanza a todos los vecinos, incluidos los presidentes de parroquias rurales y los alcaldes de barrio o equivalentes, cuyas edades estén comprendidas entre el mínimo y el máximo establecido por la costumbre del lugar. En ausencia de ésta, los menores de dieciocho años y mayores de sesenta y cinco están excluidos de tal obligatoriedad. Se recoge el concepto de "lista de faltosos" a las personas que están obligadas a asistir a la sextaferia. Asimismo se prevé la redención de la sextaferia mediante pago en metálico de las cantidades establecidas por la costumbre del lugar) o, en su caso, prestación personal. Vid. VVAA "Compilación del Derecho consuetudinario asturiano" 2007 y TOLIVAR ALAS, L. "Las prestaciones personales" Academia Asturiana de Jurisprudencia, Oviedo, 1991. En Álava los concejos pueden imponer las veredas en los términos de la normativa foral y concejil correspondiente (ver Norma Foral 21/2013, de 27 de junio reguladora de los programas de ayudas a las iniciativas para el fomento de las relaciones vecinales y a la ejecución de obras menores.

${ }^{169}$ En la regulación de Andalucía se establece una obligación para los ayuntamientos de consignación económica destinada a nutrir a las ELA, aspecto que parece indicar que la viabilidad de la misma está condicionada a las transferencias o asignaciones que el ayuntamiento pudiera hacer.
} 
el resto del municipio. La experiencia nos demuestra que no es habitual que el ayuntamiento lleve a cabo dicha obligación de garantizar unos recursos mínimos, si bien se da el supuesto de que en no pocos casos la ELM dispone de unos recursos y de unos ingresos muy superiores a los del municipio en el que se integran, de ahí que esta previsión no se lleve a término y que existan determinadas reticencias por parte de los ayuntamientos en asignar recursos a las pedanías.

Además las ELM deben elaborar y aprobar anualmente un presupuesto único, que comprenderá todos los ingresos y gastos de la misma con arreglo a las normas económico-financieras que rigen para las Corporaciones Locales ${ }^{170}$. A la hora de confeccionar el presupuesto local se les aplican las mismas reglas y la misma normativa que a los municipios, es decir, la misma regulación que está recogida en la Ley de Haciendas Locales 2/2004 (TRLHL), con la dificultad añadida, como veremos en el capítulo correspondiente a la problemática de la rendición de cuentas, de elaboración de un presupuesto por personas con la preparación inadecuada. A tal fin, el Secretario del Ayuntamiento en que radique la ELM, o el servicio establecido a tal efecto por cada Diputación, a elección de la Junta Vecinal, facilitarán el asesoramiento jurídico necesario $^{171}$.

\footnotetext{
${ }^{170}$ Es interesante la STSJ Galicia de 24 de mayo de 2007 que reconoce a la ELM la posibilidad de entablar reclamación contra el presupuesto municipal por omitir el crédito necesario para el cumplimiento de obligaciones exigibles al municipio en virtud de precepto legal o de cualquier otro título legítimo, entre los que, en su caso, se podría incluir el crédito relativo a la participación en los impuestos del ayuntamiento en la cuantía que establezca el decreto de creación.

${ }^{171}$ En el Servicio de Asistencia a Municipios de la Diputación de Palencia, por ejemplo, se les facilita un modelo completo de expediente de elaboración del presupuesto con sus diversos informes, bases de ejecución etc...., así como la asistencia necesaria para su elaboración, aprobación, publicación en el Boletín Oficial de la Provincia y posterior remisión a los órganos correspondientes, (en papel a la Comunidad Autónoma y por medios telemáticos al Ministerio de Hacienda).
} 


\section{7.- Modificación y supresión ${ }^{172}$}

Procederá la supresión de las ELM cuando los núcleos que le sirven de base dejen de reunir los requisitos que para su existencia exige esta Ley. Asimismo, podrá acordarse la supresión de las ELM en los siguientes supuestos:

a) Incumplimiento continuado y manifiesto de las competencias que detenten.

b) Cuando, celebradas elecciones locales, hubiesen quedado reiteradamente sin cubrir los órganos rectores de la entidad por falta de candidaturas. En este supuesto, iniciado el expediente de disolución y hasta que el mismo se resuelva, la administración y gestión corresponderá al Ayuntamiento.

c) Cuando se aprecien notorios motivos de necesidad económica o administrativa.

d) Cuando así lo solicite la mayoría de los vecinos.

La iniciativa para proceder a la supresión de entidades locales menores puede corresponder a quienes la tienen para su creación, a la Junta Vecinal, mediante acuerdo adoptado por la mayoría absoluta de los miembros que la forman y/o a la Consejería competente en materia de Administración Local. El procedimiento será el mismo que el establecido para su constitución, debiendo darse audiencia a todas las partes interesadas. Los motivos más habituales en la práctica donde se han dado supuesto de disolución de ELM son la falta de candidaturas en las elecciones locales, y en menor medida por motivos de necesidad administrativa. Así puedo citar como supuestos conocedores (las Diputaciones Provinciales tienen que ser oídas en Castilla y León dentro del expediente de supresión de las ELM) por haber participado en los expedientes de disolución de las mismas, la supresión, por falta de candidatos, en la provincia de Palencia de las ELM de

\footnotetext{
${ }^{172}$ La Ley 1/1998 recogía en sus Disposiciones Adicionales tercera y cuarta lo siguiente respecto de la posible supresión de las ELM a la entrada en vigor de la misma: 1. Quedarán suprimidas a la entrada en vigor de la presente Ley todas aquellas entidades locales menores que en la indicada fecha carezcan de población. 2. La Junta de Castilla y León, constatada la carencia de población, hará pública, mediante Decreto, la relación de las entidades que se encuentren comprendidas en el apartado anterior.

1. La Junta de Castilla y León iniciará las actuaciones que procedan en orden a la supresión de aquellas entidades locales menores en que concurra cualquiera de los supuestos contemplados en el artículo 71 de esta Ley. 2. También se procederá a la supresión de las entidades locales menores constituidas por el núcleo de población donde radique la capitalidad del municipio cuando carezcan de bienes o, teniéndolos, el número de electores de la entidad local menor represente la mayoría del número de electores del municipio a que pertenezca.
} 
Quintanilla de Hormigueras (perteneciente a Aguilar de Campoo), la de Pedrosa de la Vega (perteneciente al municipio de Pedrosa de la Vega, en el año 2007 ambas, y la de Albalá de la Vega (perteneciente al municipio de Renedo de la Vega) en el año 2002 por motivos de necesidad administrativa ${ }^{173}$. En todos los casos la supresión se alcanzó sin ningún problema reseñable, pero sí que es verdad que la futura gestión de los bienes pertenecientes a estas ELM suprimidas, si bien pasa al Ayuntamiento al que pertenecen, se debería prever más exhaustivamente, por lo menos en Castilla y León, las condiciones y requisitos de la explotación de los mismos, sobre todo respecto de los bienes comunales, pues ahí es donde verdaderamente está el núcleo del problema antes la situación y/o reticencia de los pueblos a la disolución.

Como supuesto no recogido en la normativa castellano-leonesa cito el recogido en la normativa andaluza en cuanto a que si la supresión se basara en que hubieran desaparecido las circunstancias de hecho que justificaron la creación de la ELA, tiene que hacer trascurrido un plazo de cinco años, previsión que estimo prudente pues exige esperar para ver el grado de desenvolvimiento de la propia entidad, e intentar con ello también evitar cambios o vaivenes de carácter político. También resulta interesante la posibilidad que recoge el régimen jurídico de Castilla La Mancha de segregar una ELM para constituirse como municipio independiente ${ }^{174}$. En la legislación navarra se

\footnotetext{
${ }^{173}$ Acuerdo de la Junta de Castilla y León de 1 de agosto de 2002 por el que se suprime la entidad local menor de Albalá de la Vega perteneciente al municipio de Renedo de la Vega (Palencia) (BOCYL 9 de agosto de 2002).

${ }^{174}$ Exponemos aquí la doctrina recogida en el Dictamen no 3/1995 del Consejo Consultivo de Castilla La Mancha, expediente relativo a la segregación de la EATIM al Municipio de Arenales de San Gregorio, dependiente del Ayuntamiento de Campo de Criptana (Ciudad Real) para su constitución como municipio independiente: "el art. 19 de la Ley 3/1991 de EELL sin abordar la especificación de su contenido, otorga un carácter preceptivo a las estipulaciones jurídicas y económicas, como instrumento llamado a resolver todas las cuestiones que surjan respecto a la liquidación de deudas o créditos contraídos por cada parte, las fórmulas de administración del patrimonio o cualquier otro asunto que convenga a los municipios afectados respecto a las obligaciones, derechos e intereses de cada uno. Del examen del contenido de otras normativas autonómicas se desprende que en la mayoría de ellas se ha instituido la figura de las aludidas estipulaciones jurídicas y económicas, bajo esa misma u otras parecidas denominaciones, como fórmula encaminada a la resolución de los problemas que puedan surgir por la liquidación de las deudas, bienes, derechos y obligaciones comunes preexistentes. Respecto a la necesidad de adoptar tales previsiones cabe citar el contenido de la sentencia del Tribunal Supremo de 31 de marzo de 1986, en cuyo fundamento quinto se menciona: es requisito fundamental e indispensable para la operación práctica de la alteración de términos municipales, que debe efectuarse junto con la división del territorio, la división de tales bienes, derechos y obligaciones, para que ella sea aprobada por el Consejo de Ministros con el acto mismo de creación del nuevo municipio y no con posterioridad a él. Todo ello, pone de manifiesto la singular importancia de recoger en el procedimiento cuantas previsiones, propuestas, pactos o estipulaciones vayan orientados a la clarificación de los conflictos de índole jurídica o económica que puedan derivarse de la segregación.
} 
prevé como causa de extinción el que la entidad no alcance la cifra de población de 16 habitantes, o por no existir tres unidades familiares, al menos, aunque se alcance la población mencionada ${ }^{175}$. Esta causa de extinción es curiosa ya que en la realidad de Castilla y León estamos asistiendo al mantenimiento y existencia de ELM con poblaciones de tres personas formando incluso una única familia como población total de la entidad.

\footnotetext{
${ }^{175}$ Se ha considerado fraudulenta la iniciativa para extinguir un concejo cuando es un hecho probado y no cuestionado que de las 20 personas que presentaron la solicitud de extinción, 15 habían solicitado su alta en el padrón municipal como vecinos del concejo poco tiempo antes de deducir dicha solicitud, resultando dados de alta, todos ellos en el mismo domicilio, por lo que se acredita lo fraudulento del ficticio empadronamiento y por ende la nulidad del acuerdo de extinción (TSJ Navarra 6 de noviembre de 2007).
} 


\section{4.- LA LEY 7/2013, DE 27 DE SEPTIEMBRE DE ORDENACION, SERVICIOS Y GOBIERNO DEL TERRITORIO DE CASTILLA Y LEÓN Y SU APLICACIÓN A LAS ENTIDADES LOCALES MENORES}

\section{1.- Planteamiento de la reforma}

Como hemos visto la Comunidad Autónoma de Castilla y León se caracteriza por su gran extensión (abarca casi una quinta parte del total del país) y rica diversidad. Esta tipología territorial ha dificultado, en no pocas ocasiones, la accesibilidad y prestación de los servicios. La ordenación de un territorio como el de esta Comunidad debe respetar las propias singularidades del territorio mismo y sus características diferenciadoras. A tal efecto en Castilla y León está aprobada la Ley 10/1998, de 5 de diciembre, de Ordenación del Territorio, que no debe confundirse con la ley que vamos a comentar $^{176}$. Asimismo debemos citar la Ley 3/2008, de 17 de junio, de aprobación de las Directrices Esenciales de Ordenación del Territorio de Castilla y León, cuyo fin último es la ordenación conjunta de la Comunidad mediante la definición de un modelo territorial que pueda emplearse como marco de referencia para los demás instrumentos de ordenación del territorio y plasmación de la política territorial de Castilla y León ${ }^{177}$.

Por otra parte y ejercitando las competencias de desarrollo normativo y ejecución de la legislación estatal básica en materia local, se promulgó en la Comunidad, como hemos visto, la Ley 1/1998, de 4 de junio, de Régimen Local de Castilla y León.

Desde este prisma, la Comunidad Autónoma decidió dar un paso más e impulsar un nuevo modelo de ordenación y gobierno del territorio que "se adapte y responda a las nuevas exigencias de la sociedad". A tal efecto se aprueba la Ley 7/2013, de 27 de

\footnotetext{
${ }^{176}$ En su Exposición de Motivos es consciente de la fragmentación administrativa municipal a la que califica de "singularidad territorial". Los objetivos generales de la Ordenación del Territorio en la Comunidad de Castilla y León, recogidos en el artículo segundo de dicha ley son: la promoción de su desarrollo equilibrado y sostenible, el aumento de la cohesión económica y social y la mejora de la calidad de vida de sus habitantes, así como la gestión responsable de los recursos naturales y la protección del medio ambiente y del patrimonio cultural.

177 Vid. COMPANY VAZQUEZ, A.M. "Las ordenación del territorio en la Comunidad de Castilla y León y su sistema de planeamiento territorial, en especial, las Directrices de Ordenación del Territorio y las Directrices de Ámbito Subregional”. Revista jurídica de Castilla y León, $n^{\circ}$ 27. Valladolid. 2012.
} 
septiembre, de Ordenación, Servicios y Gobierno del Territorio de la Comunidad de Castilla y León (BOE 1 de octubre de 2013), que entró en vigor el día 21 de octubre del 2.013 .

Ha sido ésta una norma larga en su elaboración y si bien algún autor ha recalcado que una de las notas caracterizadoras de su tramitación ha sido la participación social, en mi opinión dudo que se haya conseguido finalmente el resultado esperado $^{178}$. Es cierto que el texto de la norma se dio a conocer no solo a través de los diarios de sesiones, trámite de alegaciones y participación de todos los afectados, sino también dirigiéndose directamente a ellos (mediante escritos, participación en comisiones de estudio, a través de la web de Gobierno Abierto de la Comunidad Autónoma, etc..) e incluso celebrando jornadas informativas al respecto, pero siempre eludiendo en ellas las contestación directas a las cuestiones que planteaban tanto los regidores locales como los técnicos municipales, pues no son pocas las dudas técnicas de desarrollo y aplicación que trae consigo esta norma.

Con relación al título competencial de esta nueva ley, en materia de ordenación del territorio, el Estatuto de Autonomía de Castilla y León (EACYL) confiere competencia exclusiva a la Comunidad en materia de "ordenación del territorio, urbanismo y vivienda" ${ }^{179}$ (art. 70.1.6). En cuanto a la competencia sobre la estructura y organización de la Administración de la Comunidad (art. 70.1.2 EACYL) parece que viene amparada la norma como competencia trasversal, designada o habilitada por los específicos ámbitos sectoriales donde se les reconoce competencia y sobre los que incide la misma (fundamentalmente sanidad, servicios sociales...). Y con relación al

\footnotetext{
${ }^{178}$ CASARES MARCOS, AB. "Régimen local y prestación de servicios públicos en Castilla y León, tras la aprobación de la Ley autonómica 7/2013, de 27 de septiembre y la LRSAL" en "La Reforma de Régimen Local, comentario a la Ley 27/2013, de 27 de diciembre, de racionalización y sostenibilidad de la administración local”, Tirant Lo Blanch. Valencia. 2014pág. 777.

${ }^{179}$ Como recuerda el Dictamen del Consejo Consultivo de Castilla y León de fecha 27 de marzo de 2013 al analizar el proyecto de esta ley, la comunidad autónoma no ostenta la totalidad de las competencias sobre ordenación del territorio, ya que no es posible obviar una serie de competencias del Estado que inciden sobre el territorio: lo que ha llevado al Tribunal Constitucional a declarar que la competencia autonómica sobre ordenación del territorio no puede desapoderar al Estado de las competencias previstas en el artículo 149 CE. En este sentido el TC, en la sentencia 77/1984, de 3 de junio, señala: "La atribución de una competencia sobre un ámbito físico determinado no impide necesariamente que se ejerzan otras competencias en ese espacio como ya ha declarado el Tribunal (STC 113/1983). Esta concurrencia es posible cuando recayendo sobre el mismo espacio físico las competencias concurrentes tienen distinto objeto jurídico". Vid. CASARES MARCOS, AB. Op cit. Pág. 776.
} 
régimen local, el encuadre competencial se delimita por el art. 149.1.18 CE en relación con el art. 148.1.2 CE y lo recogido en el propio EACYL.

La redacción del EACYL en este ámbito de la organización territorial local se encuentra contenida en su Título III, el cual comienza con una declaración de principios del siguiente tenor: Las entidades locales de Castilla y Leon se regirán por los principios de autonomía, suficiencia financiera, competencia, coordinación, cooperación, responsabilidad, subsidiariedad y lealtad institucional-artículo $43.2^{180}$ , declaración que también debe verse completada con el contenido del artículo 48, precepto que establece que las relaciones entre la Comunidad Autónoma y las entidades locales se ajustarán a los principios de lealtad institucional, respeto a los ámbitos competenciales respectivos, coordinación, cooperación, información mutua, subsidiariedad, solidaridad interterritorial y ponderación de los intereses públicos afectados, cualquiera que sea la Administración que los tenga a su cargo.

Es cierto que con la planta municipal existente en esta Comunidad la prestación de los servicios en términos de homogeneidad y eficacia dista, en varias ocasiones, de alcanzar los niveles deseados que se esperan de unas instituciones maduras y que perviven en el tiempo como son las entidades locales, que en no pocos momentos han sido las grandes olvidadas del ordenamiento jurídico en nuestro país. El contexto actual de crisis económica parece que justifica el debate sobre la reforma del gobierno local (aspecto que cristalizó, como veremos a continuación, con la aprobación de la nueva Ley 27/2013 de racionalización y sostenibilidad de la administración local). Además, desde Europa se afirma que la duplicidad competencial entre diversos estamentos de

\footnotetext{
${ }^{180}$ BELLO PAREDES, S. A. "Las situación de las entidades locales en los Estatutos de Autonomía reformados: especial referencia al marco estatutario de Castilla y León”. Revista jurídica de Castilla y León, $n^{\circ}$ 20. Enero 2010. Pág. 351: "El precitado artículo 43.2 del EACyL, cuando realiza esta enumeración de principios referidos a las entidades locales, se está refiriendo tanto a principios de carácter constitucional aplicables a este tipo de entidades públicas como también a otro conjunto de principios de origen y naturaleza infraconstitucional. De esta forma, la normativa estatutaria ha tratado de compilar los principios jurídicos básicos en el ámbito local, con una evidente vocación programática y de notables consecuencias jurídicas. Además, este apartado segundo introduce una novedad ciertamente significativa, en relación con el texto constitucional, con la normativa estatal sobre régimen local y con la redacción anterior de este Estatuto de Autonomía, cual es la de extender el principio constitucional de autonomía a la totalidad de las entidades locales, cuando el resto de normas citadas, y en particular el texto constitucional, sólo la predica de municipios y provincias — artículos 137, 140 y 141 de la CE-."
} 
gobierno produce una pérdida de recursos financieros relevantes ${ }^{181}$. Si bien se ha afirmado en varios foros que estamos ante una crisis de carácter institucional, y que la reforma bien podría justificarse por la necesidad de adaptación de la administración a unos tiempos que exigen con mayor exhaustividad la aplicación de los principios de eficacia, eficiencia, de poder prestar los servicios públicos sin tener que renunciar a la identidad institucional de cada uno, pues la planta municipal subyace sobre criterios tradicionales que no se pueden reducir a términos meramente económicos. ${ }^{182}$

\section{2.- Aplicación al régimen jurídico de las entidades locales menores}

Por lo que respecta a las ELM sorprende que apenas se haya tocado la regulación de las mismas. Ésta ley se limita a prever en la "Disposición Final 8 a" 183 que

\footnotetext{
181 "Local government in critical times: policies for crisis, recovery and a sostanaible future", publicado el 16 de marzo de 2012. Consejo de Europa. Ed. Kenneth Davey.

182 Dictamen 567/2013, Consejo Consultivo de fecha 27 de marzo de 2013, pág. 18.
}

183 Disposición final octava. Entidades locales menores: 1. En el marco de la legislación básica del Estado, y de acuerdo con el mandato del Estatuto de Autonomía, se regulará y garantizará el mantenimiento de las actuales entidades locales menores, y se fomentará su modernización. 2. En el marco de la legislación básica del Estado, reglamentariamente se determinarán las especialidades que puedan corresponder en el régimen de tesorería, contabilidad y fiscalización respecto a determinadas entidades locales menores, en función de su tamaño o presupuesto. 3. Los municipios y sus entidades locales menores adecuarán sus relaciones a los principios de cohesión territorial y solidaridad dentro del municipio, con arreglo a las siguientes reglas:

a) Se podrán establecer convenios entre el municipio y cada entidad local menor o, para los anejos, se podrán realizar acuerdos plenarios de compromiso de gasto durante cada legislatura para promover la aplicación de dichos principios, en los términos previstos en la Ley de Régimen Local de Castilla y León. En el supuesto de convenios, se concretarán las fórmulas de revisión y actualización de las aportaciones o participaciones. Para garantizar la reciproca solidaridad, cuando una de las partes no libre el importe de las aportaciones o participaciones en los plazos fijados en el convenio o acuerdo plenario de compromiso de gasto, la otra parte, previa audiencia a las restantes afectadas, podrá solicitar a la Comunidad Autónoma o diputación provincial correspondiente la retención de dicho importe en los pagos que por cualquier concepto éstas hayan de realizar a la primera.

b) A falta del convenio o del acuerdo plenario municipal previsto en el apartado anterior, reglamentariamente se podrán determinar los criterios para la cuantificación de dichas aportaciones o participaciones. La Administración de la Comunidad de Castilla y León y las respectivas diputaciones provinciales podrán aplicar a los recursos económicos que no sean subvenciones u otros de naturaleza finalista, susceptibles de ser proporcionados por ambas administraciones al municipio o entidad local menor, el destino a favor de uno u otra que proceda, sin perjuicio de la posible y previa compensación recíproca de deudas vencidas, líquidas y exigibles entre ellos.

c) La obligación de cohesión territorial y solidaridad desaparecerá en el supuesto de supresión de una entidad local menor, en la forma y con los requisitos previstos en la legislación básica de régimen local, sin perjuicio de que se especifique el destino de sus bienes, y la atribución de su titularidad y 
se regulará y garantizará el mantenimiento de las actuales ELM y se fomentará su modernización, estableciendo a la par la previsión de una regulación, a través de desarrollo reglamentario, de las especialidades que puedan corresponderles a este tipo de entidades, sobre todo en cuanto al régimen de tesorería, contabilidad y fiscalización, en función de su tamaño o presupuesto, lo cual no es sólo necesario, es vital para la supervivencia y modernización de las mismas ${ }^{184}$.

Se establece la posibilidad de celebración de convenios entre las ELM y los ayuntamientos para garantizar la solidaridad entre ambos, con la novedad de que si se incumplen los plazos de aportaciones por parte de cualquiera de ambos sujetos, se solicite tanto a la Comunidad Autónoma como a la Diputación Provincial correspondiente, la retención del importe adeudado, en los pagos que por cualquier concepto éstas hayan de realizar a la entidad solicitante. Me parece interesante traer la doctrina jurisprudencial de la sentencia del TSJ de Castilla y León de fecha 15 de marzo de 2011 relativa a la interpretación de la aplicación del Convenio regulador de la financiación del Ayuntamiento de Lerma (Burgos) y sus juntas vecinales indicando que la participación de éstas en los tributos del Ayuntamiento tiene por finalizada garantizar la existencia de unos fondos mínimos para que la ELM pueda ejercer tanto las competencias que le son propias (art. 68 LRL) como aquellas objeto de delegación (art. 69 LRL), sin que sea posible sostener que esa participación se vincule a que la ELM preste específica y concretamente algún servicio. El Ayuntamiento por su parte alega que la participación en dichos tributos lo es solo para el ejercicio de aquellas competencias que han sido objeto de delegación (el caso objeto de recurso trae causa de una actividad urbanística y como la materia de urbanismo no es competencia delegable el municipio se basa en dicha circunstancia para no aplicar la financiación prevista en el Convenio), queda acreditado que no se vincula la asignación del crédito a que la ELM realice actividad alguna de carácter urbanística sino que es suficiente, del examen de los anteriores convenios existentes en el municipio con su ELM, que el Ayuntamiento

aprovechamientos al respectivo municipio en el Acuerdo de la Junta de Castilla y León por el que se suprima.

${ }^{184}$ CASARES MARCOS, AB. Op cit. pág. 845 afirma que resulta decepcionante el tratamiento que realiza esta ley respecto de la cuestión de las ELM al no dedicarlas reflexión alguna a lo largo de su articulado pese a su trascendencia y proliferación en nuestra Comunidad Autónoma. 
conceda licencia urbanística y perciba tributos (en este caso el ICIO-Impuesto de Construcciones, Instalaciones y Obras y la Tasa por Urbanización).

Asimismo se modifica el artículo 69 de la ley 1/1998, de 4 de junio de régimen local en el siguiente sentido: Cuando las Entidades Locales Menores realicen obras o presten servicios por delegación del municipio, el coste de unas y otros que no puedan financiarse con precios públicos o tasas y contribuciones especiales será soportado por aquéllas y por los municipios de que dependan en los términos que fije el acuerdo de delegación. La Administración de la Comunidad de Castilla y León y las respectivas Diputaciones Provinciales promoverán la aplicación por el municipio de los principios de cohesión territorial y solidaridad de la "comunidad municipal”, en el marco del artículo 43.3 del Estatuto de Autonomía de Castilla y León (la Comunidad y las entidades locales de Castilla y León promoverán la cohesión y el equilibrio de todos sus territorios, con especial atención a las zonas periféricas y a las más despobladas y desfavorecidas) ${ }^{185}$. De igual forma, promoverán la aplicación por la ELM de estos mismos principios hacia la comunidad municipal.

Con relación a lo que afecta a estas entidades menores, cabe destacar que la Disposición Derogatoria única de la ley objeto de este comentario, deroga la

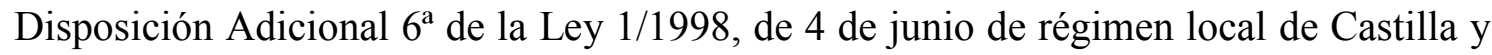
León, que era el precepto que regulaba el desempeño de las funciones de los puestos de secretaría en estas entidades. Este aspecto será objeto de un capítulo independiente como se verá.

$\mathrm{Y}$ un aspecto que quiero destacar y que tendrá un efecto negativo en cuanto a la gestión de las ELM (que enlaza con el problema analizado en el capítulo relativo al desempeño del puesto de secretaría) es la previsión que recoge esta ley de creación o reordenación del mapa de agrupaciones de municipios para el sostenimiento en común

\footnotetext{
${ }^{185}$ A los efectos de este artículo, se entiende por comunidad municipal la integrada por el núcleo de población capital del municipio, así como, en su caso, por la entidad o entidades locales menores que el municipio pudiera tener, y los anejos separados de la cabecera que pudieran existir.
} 
del puesto de secretario ${ }^{186}$, que deberán llegar a aunar una población de 500 habitantes como regla general y de 1.000 habitantes si se integran en una mancomunidad de interés general, puesto cabe que nos hagamos la siguiente pregunta, y es que ¿cuántos municipios se tienen que agrupar, dada la escasa población de cada uno de ellos, hasta alcanzar la cifra de 1.000 habitantes?, es decir, ¿un puesto de secretario-interventor, sin más personal que le auxilie, para unos, pongamos de media, ocho municipios?, ni que decir queda en cuanto a cómo van a ser atendidas las ELM si las hay en esa agrupación. Si bien por parte de la Junta de Castilla y León se ha comentado en foros de debate que la competencia para la creación de esas nuevas agrupaciones de municipios en función de los tramos de población recogidos en la LORSEGO, deberá ser de las Diputaciones Provinciales, puesto que en Castilla y León tienen las mismas delegadas (en virtud del Decreto 256/1990) la competencia de autorización para la constitución de las mismas (competencia atribuida por el RD 1732/1994 en su art. 3 a las CCAA), no es menos cierto que ni la LOSERGO lo dice ni el RD citado, puesto que en todo caso las agrupaciones para el sostenimiento en común del puesto de secretaría son de carácter voluntario, y donde la ley no lo dice, la CA no puede extender ni interpretar de la manera que lo está haciendo.

Como vemos apenas sí se han acordado de estas entidades en la nueva regulación territorial autonómica, y es una lástima que al abordar una empresa como es ésta, de la "supuesta" ordenación territorial, no se de una solución o se aproveche el momento para establecer un régimen más flexible y acorde con la realidad de estas ELM. Dentro de la estructura de la nueva ley, en la que se prevé la creación de unidades de ordenación, áreas estratégicas y demás figuras novedosas para establecer el entramado territorial en orden a la reordenación de competencias, las ELM siguen siendo una asignatura pendiente del legislador. Casi podríamos decir que se han olvidado del último escalón territorial.

A continuación se presenta un Cuadro resumen de los diferentes regímenes jurídicos que existen en las comunidades autónomas del país, con relación a las ELM:

\footnotetext{
${ }^{186}$ REBOLLO PUIG, M. en ob cit. pág. 200, recuerda que la STC 4/1981 de 2 de febrero confirmo la constitucionalidad de las agrupaciones forzosas de municipios, puesto que la propia $\mathrm{CE}$ en su art. 141.3 lo recoge y afirma que dicha posibilidad está ligada al art. 152.3 CE estimando que la autonomía local está limitada por la posibilidad de crear agrupaciones de municipios, y cita dicha sentencia como una de las causas justificativas la escasez de medios como puede ser las agrupaciones para el sostenimiento en común de los puestos de secretaría municipal.
} 


\begin{tabular}{|c|c|c|c|c|c|}
\hline CCAA & Normativa y Definición & Creación & Potes. y Competencias & Órganos de Gobierno & Disolución \\
\hline ANDALUCIA & $\begin{array}{c}\text { Ley } 5 / 2010 \\
\text { Entidades Vecinales } \\
\text { E.L.A. }\end{array}$ & $\begin{array}{l}\text { Instrumento de creación. } \\
\text { No requisito poblacional }\end{array}$ & $\begin{array}{c}\text { Destacan la posibilidad de } \\
\text { competencias transferidas y } \\
\text { no delegadas }\end{array}$ & $\begin{array}{l}\text { Presidente } \\
\text { Junta Vecinal }\end{array}$ & 5 años \\
\hline ARAGON & Ley $7 / 1999$ & $\begin{array}{l}\text { Requisito poblacional de al } \\
\text { menos } 250 \text { hab. }\end{array}$ & Licencias & $\begin{array}{c}\text { Presidente } \\
\text { Junta } \\
\text { Concejo abierto } 40 \mathrm{hab}\end{array}$ & Continuidad de edificación \\
\hline ASTURIAS & Ley $11 / 1986$ & $\begin{array}{c}\text { Diferencia entre Parroquia y } \\
\text { ELM } \\
\end{array}$ & & $\begin{array}{c}\text { Presidente } \\
\text { Junta parroquial }\end{array}$ & $+50 \%$ núcleo \\
\hline BALEARES & Ley $20 / 2006$ & 50 años & $\begin{array}{c}\text { Licencias, Archivos, Fiestas, } \\
\text { Agua }\end{array}$ & $\begin{array}{c}\text { Presidente } \\
\text { Junta Vecinal } \\
\text { RO } \\
\end{array}$ & \\
\hline CANTABRIA & Ley 6/1994 & + 500 hab. & $\begin{array}{c}\text { Promover la concentración } \\
\text { parcelaria }\end{array}$ & $\begin{array}{c}\text { Presidente } \\
\text { Junta Vecinal } \\
\text { Comisión Cuentas }\end{array}$ & \\
\hline CASTILLA LA MANCHA & Ley 3/1991 & & Iniciativa alteración términos & $\begin{array}{c}\text { Presidente } \\
\text { Junta Vecinal }\end{array}$ & Segregación 1000 hab. \\
\hline CATALUÑA & Decreto Leg. 2/2003 & & Tráfico. Alumbrado & $\begin{array}{c}\text { Presidente } \\
\text { Junta Vecinos }\end{array}$ & \\
\hline GALICIA & Ley 5/1997 & $\begin{array}{c}\text { Distingue entre parroquia y } \\
\text { ELM }\end{array}$ & & $\begin{array}{l}\text { Alcalde pedáneo } \\
\text { Junta Vecinal }\end{array}$ & \\
\hline LA RIOJA & Ley $1 / 2003$ & +50 hab. & & $\begin{array}{c}\text { Alcalde pedáneo } \\
\text { Junta Vecinal } \\
\text { Concejo abierto/ R.O. }\end{array}$ & \\
\hline MADRID & Ley $2 / 2003$ & & & & \\
\hline MURCIA & Ley 6/1998 & & $\begin{array}{c}\text { Policía urbana, tráfico, agua, } \\
\text { alumbrado y recogida } \\
\text { basuras }\end{array}$ & & \\
\hline NAVARRA & Ley Foral 6/1990 & $\begin{array}{l}\text { Álava concejos }=15+3 \\
\text { UNIDADES }+100 \mathrm{HAB}\end{array}$ & $\begin{array}{l}\text { Licencias, cementerio, } \\
\text { archivo }\end{array}$ & $16-50+50 \mathrm{hab}$ & No 16 hab \\
\hline PAIS VASCO & $\begin{array}{c}\text { LFA } 11 / 1995 \text { NFG 2/2003 } \\
\text { NFV 8/1993 }\end{array}$ & Álava: unidad fogueral & $\begin{array}{c}\text { Álava: proc. Urbanístico, } \\
\text { expropiación }\end{array}$ & $\begin{array}{c}\text { Diferencia concejo cerrado y } \\
\text { abierto } \\
\text { Fiel de fechos }\end{array}$ & \\
\hline $\begin{array}{l}\text { COMUNIDAD } \\
\text { VALENCIANA }\end{array}$ & Ley $8 / 2010$ & 50 vecinos al menos & $\begin{array}{c}\text { Ordenación tráfico, } \\
\text { pavimentación vías urbanas }\end{array}$ & $\begin{array}{c}\text { Presidente } \\
\text { Junta Vecinal }\end{array}$ & \\
\hline
\end{tabular}

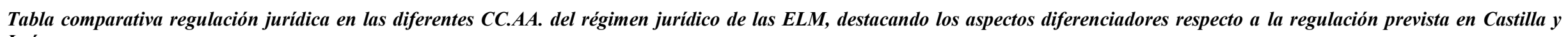
León. 


\section{5.- LA LEY 27/2013, DE RACIONALIZACIÓN Y SOSTENIBILIDAD DE LA ADMINISTRACIÓN LOCAL}

\section{1.- Contexto $y$ antecedentes de la reforma}

La situación actual respecto del régimen jurídico de estas entidades ha dado un giro radical a raíz de la aprobación de la Ley 27/2013, de 27 de diciembre de racionalización y sostenibilidad local (LRSAL), que modifica sustancialmente la LRBRL. Si bien en estos últimos quince años hemos asistido a un desarrollo, casi podríamos decir, exponencial del sistema territorial autonómico no sólo por parte del Estado en sí, si no por las propias comunidades a las que se había creado y promovido, paralelamente podemos afirmar que se ha desatendido al régimen local, y que se ha llegado a provocar un mayor centralismo generado por parte de las CCAA hacia los entes locales, que el que podría realizar el Estado ${ }^{187}$.

La Ley 7/1985, de 2 de abril de Bases del Régimen Local (LRBRL) partía de unos postulados claros ${ }^{188}$ :

- Establecimiento de una perspectiva en la delimitación del régimen local entendiendo éste como el ordenamiento institucional de la Administración Local.

- Pertenencia de la ley al llamado "bloque de constitucionalidad" en materia de régimen local ${ }^{189}$.

- Concepción de la autonomía y el ordenamiento local como un sistema único y total, compuesto internamente de dos piezas principales: municipio y provincia, manteniendo la identidad y pervivencia del municipio en su concepción original y

\footnotetext{
187 LAGO NUÑEZ, G. "La tercera reforma del régimen local en España" El Consultor de los Ayuntamientos y Juzgados. La Ley 24/2014: El autor no solo pone de relieve o denuncia esa desatención, si no que recuerda que la administración local también forma parte de la misma organización territorial del Estado y de las CCAA, y afirma que el Estado lo ha dejado a su suerte (al régimen local), injertando una estructura basal (la local) en otra artificial (las CCAA).

188 PAREJO ALFONSO, L. "La autonomía local desde el punto de vista de su realización efectiva" Revista electrónica CEMCI $n^{\circ}$ 18. Oct. Dic. 2008. Pág. 5.

${ }^{189}$ LAGO NUÑEZ, G. op cit, pág. 5: "Esta idea aun controvertida y anticipadora hasta cierto punto de la teoría del "principio de la función" que parece irse abriendo paso como nueva regla de ordenación de las relaciones entre normas, pero que el TC no desautorizó en modo alguno en su Sentencia 214/1989, de 21 de diciembre, y cuya doctrina posterior ha ido perfilando hasta decantar de modo estricto el contenido del referido "bloque".
} 
potenciando el papel del "macro-municipio-subsidiario" en la figura de la provincia $^{190}$.

Desde su aprobación la LRBRL ha sido objeto de varias modificaciones puntuales, destacando la realizada en el año 1999 con motivo del paquete de medidas conocidas como "Pacto Local", y la reforma operada en el año 2003:

- La Ley 11/1999, de 21 de abril, derivada del Pacto Local, modifica la LRBRL poniendo el punto de fuerza en el fortalecimiento de la figura presidencialista del Alcalde, el carácter necesario de la Comisión Informativa en todos los municipios con población superior a 5.000 habitantes, la regulación de la moción de censura más restrictiva en la LOREG y la introducción de la cuestión de confianza; la introducción en las sesiones plenarias de la sustantividad propia de la fase de control.

- La Ley 57/2003, de 16 de diciembre criticó y fundamentó principalmente su necesariedad en dos aspectos: el modelo orgánico -funcional y el rígido uniformismo generalizado en la mayoría de los municipios ${ }^{191}$. Estos dos temas produjeron que se incluyera en la LRBRL el Titulo $\mathrm{X}$ dirigido a establecer un nuevo régimen para grandes municipios, el cual no acabó con la uniformidad, sino que además introdujo un coste adicional en la nueva naturaleza del personal directivo.

$\mathrm{Y}$ es en este punto donde quiero hacer una observación importante, porque si se demanda un régimen especial para municipios de gran población, ¿para cuándo un régimen específico para los pequeños municipios?, es decir, para los de menos de 100 o de 500 habitantes, ya que, obviando la existencia del régimen de Concejo Abierto (que además ha sido esquilmado en la última reforma de la LRBRL y la LOREG en el año 2011), nunca se ha minimizado, flexibilizado o simplificado el régimen jurídico a

\footnotetext{
${ }^{190}$ LAGO NUÑEZ, G. op cit pág.6: La idea del autor de la imprescindible casi podríamos decir necesidad de existencia de las provincias en su labor de cobertura de las insuficiencias de capacidad gestora de los municipios, es fundamental en el sistema local español, y pese a las dificultades que se ha encontrado la provincia, pues choca con la no aceptación por las CCAA, destaca la perseverancia con la que el escalón provincial se defiende y resiste, aspecto que veremos al analizar la nueva LRSAL.

191 Como principales novedades de esta ley destacamos: la parlamentarización del Pleno; la desnaturalización de la figura de Alcalde; y el incremento de la participación ciudadana.
} 
aplicar a los municipios y por ende a las $\mathrm{ELM}^{192}$. Si bien la Ley 1/1998, de 4 de junio de régimen local de Castilla y León recoge la previsión de un régimen especial para los municipios con población inferior a 5000 habitantes, tal regulación nunca ha sido abordada $^{193}$.

Esta reforma "parcial" no se ocupó de los problemas de fondo que afectan al sector local de la administración, tales como los relacionados con la hacienda local y el sistema competencial, aspectos que se afrontaban en el "Libro Blanco de la Reforma del Gobierno Local" del año 2005 y el "Borrador de Anteproyecto de Ley de bases del Gobierno Local”, que asumen los problemas en el ámbito competencial, entendiendo válida la atribución de las mismas tanto por medio de ley de bases del Estado como a través de las reformas estatutarias, abriéndose así la corriente doctrinal por la que se deriva a los Estatutos la configuración de la Autonomía Local. Sendos documentos reconocen la necesidad de un único modelo de organización básico, un régimen orgánico único en los municipios y abordan el sistema competencial local, pero finalmente todo quedó olvidado en los despachos ministeriales.

\section{2.- Tramitación de la LRSAL}

Posteriormente, y ya inmersos de lleno en el contexto de crisis económica e institucional que afectó a nuestro país, desde el mes de diciembre de 2011 se elevaron enérgicas las voces que demandaban una reforma de las AAPP, y así la misma va a pivotar, como veremos, sobre el concepto y principio de la estabilidad presupuestaria.

\footnotetext{
192 REBOLLO PUIG, M. "La supresión de los pequeños municipios: régimen, alternativas, ventajas e inconvenientes" Revista de estudios locales y autonómicos $n^{\circ}$ 308. 2008. Pág. 187, entiende el autor la necesidad de que exista un régimen especial para los pequeños municipios, como alternativa a su supresión, y si bien afirma que en esta dirección se debe y se puede avanzar mucho, poco se ha hecho hasta el momento.

193 Artículo 77 LRL: Los municipios de Castilla y León de población inferior a 5.000 habitantes tendrán un régimen especial ajustado a las siguientes normas: a) La organización complementaria y el funcionamiento responderán a los principios de sencillez, economía, eficacia y participación ciudadana. b) De acuerdo con los principios establecidos en el apartado anterior, la Junta de Castilla y León aprobará un Reglamento orgánico que regirá en defecto del que pueda aprobar el Pleno del Ayuntamiento. c) Por la Consejería competente en la materia se establecerán modelos-tipo de actas, acuerdos, ordenanzas, plantillas y otros documentos municipales para facilitar una actuación administrativa unitaria y ágil.
} 
Sobre la base de apostar por una racionalización del sector público, se redactó el llamado "Informe CORA""194 y en base al mismo se aprobó el "Acuerdo para la reducción de las cargas administrativas y mejora de la regulación” en junio de 2013. Dicho documento, y basándose en el Informe anteriormente citado, destaca la necesidad de regulación del impulso a la facturación electrónica, y el control de la deuda comercial en el sector público; asimismo la reducción de organismos y evitación de duplicidades lleva a poner en el punto de mira a los órganos externos de fiscalización $\left(\mathrm{OCEXS}^{195}\right)$, y la centralización de la contratación, por ejemplo.

Pero la medida que ha orquestado todo el cambio o reforma ha sido la aprobación de la Ley Orgánica de Estabilidad Presupuestaria 2/2012, de 27 de abril (LOEP), norma que se ha convertido en el continuo "mantra" que repiten desde la AGE y que de cara a la administración local ha supuesto la imposición de medidas de forzoso cumplimiento, llegando en el supuesto de incumplimiento de las mismas, a preverse una intervención en la propia existencia municipal.

Otro cambio, enmarcado dentro de la nueva Ley Orgánica 9/2013, de 20 de diciembre de control de la deuda comercial del sector público, es el que supone para las EELL la asignación a la figura del interventor local del control del cumplimiento del periodo medio de pago, remarcando el protagonismo de estos funcionarios en materia de cumplimiento presupuestario, control y estabilidad, como se verá. A todo este marco contextual se suma la Ley 13/2013, de 9 de diciembre de Transparencia, acceso a la información y buen gobierno, que afecta de manera muy directa a las EELL y también a las ELM, que parecen estar viviendo al margen de toda esta vorágine legislativa.

Toda esta situación ha sido el caldo de cultivo para la aprobación de la LRSAL. Esta nueva ley ha tenido multitud de versiones de su anteproyecto, a las cuales o bien se les ha dado comunicación oficial o han sido objeto de filtración, lo que ha dado lugar a un constante debate sobre la misma, y que ha llevado a que, desde el texto inicialmente comunicado en el mes de julio del año 2012 al texto que finalmente ha sido objeto de

\footnotetext{
${ }^{194}$ Informe de la Comisión para la Reforma de las Administraciones Públicas, creada en octubre de 2012.

195 CARPIO CARRO, M. "El Informe CORA y la Administración Local". El Consultor de los Ayuntamiento y juzgados, $n^{\circ}$ 14. 2013. Pág. 1395. "Se propone que sea el TCu el que realice dicha función, creándose 12 secciones territoriales y prescindiéndose de los OCEX autonómicos".
} 
aprobación, se haya ido limando y cambiando el articulado inicial; y cuesta reconocer en el mismo a la primera versión del documento, así como a la intención original que tenía el Gobierno de la Nación con la redacción de dicha norma.

A lo largo de la tramitación de la ley merece especial mención el "Dictamen 567 del Consejo de Estado de 26 de junio de 2013", cuyas indicaciones han sido determinantes a la hora de conceptuar por ejemplo el coste estándar o la llamada de atención de interjección en la autonomía local en cuanto a la traslación de competencias municipales a otras AAPP.

En cuanto a la tramitación parlamentaria la publicación en el Boletín Oficial de las Cortes Generales abrió un periodo para la presentación de enmiendas, cuyo debate se produjo en octubre del 2013 (474 enmiendas ${ }^{196}$ ), incorporándose al texto la enmienda 426 con las correcciones del Grupo parlamentario Popular. En la fase del Senado ${ }^{197}$ fueron presentadas 447 enmiendas, incorporándose también las presentadas por el

\footnotetext{
${ }^{196}$ La "Federación Española de entidades locales menores" en el Análisis Jurídico del Proyecto de la LRSAL realizado el 11 de septiembre de 2013, señalan como primera medida, la sustitución de la denominación de EATIM por el de Entidad Local Autónoma (ELA) que ya se recibe en diferentes CCAA; proponen que en el art. 3.2 se incluyan las ELA existentes o en proceso de creación a la entrada en vigor de la ley como entes que gozan de la condición de entidades locales; que en el art. 36.2 referido a los fines de la Provincia se añadiera en el apartado b) que la aseguración de la prestación integral y adecuada de los servicios de competencia de los municipios y las ELA y la asistencia y cooperación jurídica, económica y técnica sea hacia los municipios y las ELA, así como los Planes Provinciales; que no se limite la creación de nuevos municipios a que al menos existan 5000 habitantes; que sea suprimido el art. 24 bis y que se mantenga el art. 45 LRBRL con ciertas modificaciones reconociendo un sistema competencial a las mismas, un sistema de recursos propios y sobre todo la propuesta de supresión de la posibilidad de disolución de la ELA por no presentar sus cuentas, ya que se trata de una medida absolutamente desproporcionada, sustituyéndola por una sanción a sus responsables, acorde con el incumplimiento. Por otra parte debe ampliarse el plazo de 18 meses para que las ELA presenten sus cuentas $\mathrm{y}$, asimismo, posibilitar su presentación por medios no telemáticos, puesto que no todas tienen acceso a internet. Asimismo quiero destacar la propuesta de enmienda de la Asociación de Concejos de Álava de fecha 12 de septiembre de 2013, por la que abogaban en la distinción en el texto normativo que se estaba tramitando entre Entidades Locales Menores de Régimen común y los Concejos del Territorio Histórico de Álava, por la que se quería adicionar un párrafo $3^{\circ}$ a la Disposición Adicional primera.
}

197 El Secretario general de la Federación Española de Entidades Locales Menores, GREGORIO MARTINEZ, M. "Las entidades locales menores tras la LRSAL" Revista El Consultor y los juzgados $n^{\circ}$ 5. 2014. Pág. 570: califica de acierto que se haya modificado en el Senado los artículos que afectaban al núcleo principal de las ELM, y en concreto: la supresión de un plumazo de todas las ELM existentes, en el borrador inicial de julio del 2012; la supresión de la condición de entidad local, se mantienen dicha condición para las existentes; y la supresión de ELM en base a la mala situación del municipio matriz art. 116 bis) e); si bien afirma que desde la Federación se consideró de vital importancia que quedara establecido el marco general de estas entidades en la LRSAL, tal como ocurre con el resto de entidades, a fin de que las líneas básicas de organización, funcionamiento, competencias y recursos sea homogénea en todo el Estado y señala que ha sido una oportunidad desaprovechada para revisar la situación de estas entidades. 
Grupo Popular ${ }^{198}$. El Pleno del Congreso aprobó el texto definitivo el 19 de diciembre de 2013 (BOCG 27 de diciembre de 2013; BOE 30 de diciembre de 2013).

\section{3.- Fundamentos de la LRSAL}

Al pasar a analizar la LRSAL en su Exposición de Motivos encontramos la justificación principal de la misma y como hemos dicho, la piedra angular sobre la que pivota la reforma: el artículo $135 \mathrm{CE}^{199}$ que tras la modificación operada en el año 2011 exige que las AAPP adecuen su actuación al principio de estabilidad presupuestaria ${ }^{200}$.

Los objetivos de la LRSAL parecen claros:

- Clarificar las competencias municipales;

- Racionalizar la estructura organizativa de la Administración Local;

- Establecer un control económico y presupuestario más riguroso, reforzando la figura del interventor local;

- Favorecer la iniciativa económica privada.

Se apuesta por un reforzamiento del papel de las Diputaciones Provinciales en cuanto a coordinadoras e incluso prestadoras de servicios si los municipios no pueden

\footnotetext{
${ }^{198}$ Podemos destacar por ejemplo, las enmiendas $\mathrm{n}^{\mathrm{o}}$ 2, 6, 14 del Grupo mixto donde manifiestan que la supresión de la condición de entidad local de las EATIM del art. 3.2 LRBRL es una materia típica de la competencia exclusiva de las CCAA en materia de régimen local. Por lo que es necesario ajustar la normativa a lo dispuesto en el art. 149.1.18 CE (BO Cortes Generales Senado 28.11.2013, pág. 109).

199 ESTEVE PARDO, ML. "El impacto del principio de estabilidad presupuestaria sobre los Gobiernos Locales...": "el reformado artículo 135 CE impone que todas las administraciones públicas adecuen sus actuaciones al principio de estabilidad presupuestaria. La LOEP ha traducido este principio para las EELL como una exigencia de equilibrio presupuestario y no permite a estos entes incurrir en el menor déficit estructural, lo que sí permite al Estado y a las CCAA”. Vid. LAGO NUÑEZ, El Consultor de los ayuntamientos y juzgados $n^{\circ} 9.2014$. Pág. 985.

200 RIVERO YSERN, JL. "La provincia en la Ley de Racionalización y sostenibilidad local 27/2013".http://laadministracionaldia.inap.es/noticia.asp?id=1503369\&nl=1\&utm_source=newsletter\&ut m_medium=email. 9 de junio de 2014. Revista General de Derecho Administrativo 36 (Iustel - mayo 2014): Esta breve referencia a la LOEP es imprescindible para entender el alcance de la LRSAL. Así los justifica la exposición de motivos de esta ley, señalando como uno de los objetivos: "una Administración una competencia". La relación entre la LRSAL y los textos legales que enmarcan jurídicamente la crisis es evidente y permite avanzar una conclusión: no estamos ante una Reforma del régimen local, sino ante una específica aplicación del "Derecho de crisis" a las Administraciones Públicas.
} 
realizarlos adecuadamente. Pero el problema es que, en mi opinión, finalmente no se cumple con la intención inicial de reordenamiento de la administración local pura y dura, y ello porque no se ponen en práctica políticas decididas de fusión municipal. Sí se recoge la posibilidad (también en la Ley autonómica castellano leonesa 7/2013-LOT) pero no de forma imperativa, seguramente por el fuerte sentimiento de pertenencia al municipio que tiene la población y por evitar posibles conflictos políticos. Por ello la solución al problema de la planta local y el inframunicipalismo se ha desviado a la creación de mancomunidades y comarcas (supuesto, como hemos visto, que ha sido la opción de la -LOT- $)^{201}$, y que ha sido criticado por sectores de la doctrina el hecho de que la creación de servicios supramunicipales difícilmente puedan resolver el grave problema de la planta local española, y que la experiencia ha demostrado que, por ejemplo, en el caso de las mancomunidades, han servido para atender de forma limitada problemas puntuales, pero no es la solución más adecuada hacia la actual planta local, con la necesidad de estabilidad que requiere el ordenamiento territorial, el apoyarse en un mecanismo jurídico voluntario como es la mancomunidad. En el caso de Castilla y León además esas MIG supuestamente voluntarias van a convertirse en forzosas, porque si no la ayuda cooperativa económica a recibir por parte de la CA no se va a poder cristalizar, va a ser una “conditio sine qua non”. Algún autor como DIAZ LEMA afirma que "los intentos de algunas administraciones autonómicas de "dirigir" e incentivar por la vía de subvenciones la creación de mancomunidades, sigue adoleciendo del mismo vicio de raíz: la voluntariedad”. No puede ser más acertado al caso de Castilla y León.

\section{4.- Afectación de la LRSAL al régimen jurídico de las entidades locales menores}

De todo lo expuesto, lo más destacable para el tema que nos ocupa está dentro del concepto llamado del "redimensionamiento del sector público" y que afecta de una manera directísima al régimen de las ELM: la ley procede a una reestructuración

\footnotetext{
${ }^{201}$ DIAZ LEMA, JM. Op cit pág. 75: No duda en tildarlo de "placebo" para cubrir las apariencias. Vid. GRACIA HERRERO, FJ. La racionalización de la estructura organizativa en los pequeños municipios tras la reforma local". El Consultor de los ayuntamientos y juzgados, $n^{\circ}$ 5. 2014. Pág. 533: "En los países de nuestro entorno (Alemania, Italia, Grecia y Portugal) la reducción del número de municipios independientes administrativamente ha sido la solución adoptada para la reducción del gasto público, sin embargo, aquí en España, pese las distintas opiniones vertidas al respecto, no se apuesta por la reducción del número de ayuntamientos.
} 
del sector público y así despoja de la condición de entidades locales a las EATIM $^{202}$, derogando el artículo 45 LRBRL y suprimiéndolas de la redacción del art. 3.2 a) ${ }^{203}$. Si bien se mantiene la personalidad jurídica de las EATIM existentes con anterioridad a la entrada en vigor de la LRSAL ${ }^{204}$ (o que hubieran iniciado su procedimiento de constitución antes del 1 de enero de 2013 según la DT 5ª).

Así en el nuevo artículo 24 bis se dice: "Las leyes de las Comunidades Autónomas sobre régimen local regularán los entes de ámbito territorial inferior al Municipio, que carecerán de personalidad jurídica, como forma de organización desconcentrada del mismo para la administración de núcleos de población separados, bajo su denominación tradicional de caseríos, parroquias, aldeas, barrios, anteiglesias,

\footnotetext{
${ }^{202}$ MORENO SERRANO, B. "Las 10 claves de la LRSAL" Página web El Consultor On Line Enero 2014: señala que el dictamen del Consejo de Estado ya había advertido de la "mutación" de la naturaleza jurídica de las EATIM de nueva creación al privárseles de la personalidad jurídica, destacando que se trata de entidades "con un considerable arraigo en muchos lugares del territorio español y que, por el efecto disuasorio de la tendencia a segregar municipios como mecanismo de reafirmación de la singularidad de núcleos de población que producen, han desempeñado un significativo papel en la configuración de la planta municipal". Además advierte que la regulación de los requisitos par al a creación supresión y atribución de competencias a estas entidades escapa al ámbito en el que se desenvuelve la legislación básica del estado, como señalara la STC 214/1989. Ninguna de estas observaciones ha sido tenida en cuenta por la LRSAL.

En palabras de PAREJO ALFONSO, L. "se produce la degradación de las EATIM reconocidas por las CCAA, que figuraban en la lista legal de la que también tenían la condición de EELL (art. 3 LRBRL), a organizaciones desconcentradas reguladas por la ley autonómica, pero bajo la condición de que resulte la opción más eficiente de acuerdo con la legislación de estabilidad presupuestaria y sostenibilidad financiera (art. 24 bis LRBRL), en "Algunas reflexiones sobre el impacto de la Ley 27/2013, de 27 de diciembre, sobre el modelo de autogobierno municipal", Cuadernos de Derecho Local $n^{\circ} 34$. Madrid 2014. pág. 15.
}

${ }^{203}$ Alegaciones de la FEMP al ALRSAL remitidas el 9 de abril de 2013: "La modificación que se establece del artículo 3.2 de la LBRL implica la desaparición de las EATIM, Entidades de ámbito territorial inferior al municipio, de entre las Entidades Locales enumeradas en este apartado.

Esta desaparición es consecuencia de la modificación, incorporada también en esta Ley, del artículo 45 de la LBRL, que deja a estas Entidades como una forma de organización desconcentrada del municipio, para la administración de núcleos de población separados, carente de personalidad jurídica.

La regulación de estas Entidades es una materia típica de la competencia exclusiva de las Comunidades Autónomas en materia de régimen Local. La intervención del Estado hasta el punto de privarlas con carácter general de personalidad jurídica, difícilmente puede justificarse al amparo de las competencias que le atribuye el artículo $149.1 .18^{\text {a }}$ de la Constitución.

Por otro lado, además de la necesidad de respetar las competencias de las CC. AA. en esta materia, el juego de lo dispuesto en el nuevo artículo 45 de la LBRL con lo establecido en la Disposición Transitoria Tercera del Anteproyecto va a crear confusión en tanto que en un futuro podrán convivir Entidades Locales menores con personalidad jurídica (las creadas antes de la entrada en vigor de esta norma) con otras que no la tendrán (las creadas a partir de esa entrada en vigor)".

${ }^{204}$ PAREJO ALFONSO, L. op cit pág. 15 señala que "cuesta entender que se admite la conservación de la personalidad en las que se hallaren en proceso de constitución al momento de la entrada en vigor de la Ley (DT $\left.5^{\mathrm{a}}\right)$.

Asimismo el Dictamen 567/2013, del Consejo de Estado al ALRSAL de 26 de junio de 2.013 asevera que el privarles de personalidad jurídica a las ELM produce una mutación de su naturaleza jurídica. 
concejos, pedanías, lugares anejos y otros análogos, o aquella que establezcan las leyes. [...] Solo podrán crearse este tipo de entes si resulta una opción más eficiente para la administración desconcentrada de núcleos de población separados de acuerdo con los principios previstos en la LOEP”205.

El Dictamen 567/2013, del Consejo de Estado ya advertía lo siguiente: “Todos los Estatutos de Autonomía o, en su caso, las leyes autonómicas sobre régimen local aprobadas en desarrollo de sus previsiones, atribuyen a las Comunidades Autónomas la competencia para crear este tipo de demarcaciones supra e inframunicipales. En relación con ello, el Tribunal Constitucional ha declarado que "esta competencia autonómica no excluye, ciertamente, la competencia estatal para dictar las normas básicas sobre la materia, pero sí la posibilidad de que el Estado cree o mantenga en existencia, por decisión propia, unas entidades locales de segundo grado que, como tales, solo los órganos de las correspondientes Comunidades Autónomas (...) son competentes para crear o suprimir" (STC 179/1985).

En esta misma línea, refiriéndose con carácter general a todas las entidades locales no necesarias -y, por tanto, también a las llamadas "entidades locales menores"-, la STC 214/1989 -que declaró inconstitucional un precepto básico en el que se reconocía al Estado la facultad de atribuir competencias a las entidades enumeradas en el artículo 3.2 de la LBRL- dejó sentado que tales entidades "entran en cuanto a su propia existencia en el ámbito de disponibilidad de las Comunidades Autónomas que dispongan de la correspondiente competencia. Se trata, en consecuencia, de unas Entidades con un fuerte grado de "interiorización" autonómica por lo que, en la determinación de sus niveles competenciales, el Estado no puede sino quedar al margen. Corresponde, pues, en exclusiva a las Comunidades Autónomas determinar y fijar las competencias de las Entidades locales que procedan a crear en sus respectivos ámbitos territoriales".

A la luz de la jurisprudencia constitucional extractada, no ofrece dudas que la regulación de los requisitos relativos a la creación y extinción de estas entidades -y aun la correspondiente a la atribución de competencias- escapa al ámbito en que debe

\footnotetext{
${ }^{205}$ MELLADO RUIZ, L. "Consecuencias derivadas de la supresión del principio de mayor proximidad". El Consultor de los Ayuntamientos $n^{o}$ 5. Marzo 2014 pág. 504.: "El art. 24 bis supone una "mutación legal" de la naturaleza jurídica de las futuras entidades inframunicipales- con el matiz no obstante importante de que su regulación efectiva habrá de realizarse a nivel autonómico-, que dejan de ser entidades con personalidad jurídica propia para convertirse en organizaciones desconcentradas del municipio de adscripción".
} 
desenvolverse la legislación básica del Estado, lo que obliga a reconsiderar la regulación proyectada en aquellos aspectos cuya determinación por el legislador estatal pueda suponer una intromisión en la esfera competencial autonómica no admisible desde el punto de vista del esquema constitucional de distribución de competencias; en particular, la supresión de estas entidades como consecuencia de la disolución imperativa en los supuestos previstos en el anteproyecto", aspecto éste que ha sido muy criticado en relación con el citado artículo 24 bis LRSAL.

Así se establece una nueva regla: "solo podrán crearse [...] si resulta una opción más eficiente para la Administración descentralizada de núcleos de población separados" 206 . Ante esta nueva regulación ya hay opiniones sobre si la legislación básica estatal no se ha excedido en su regulación o más bien ha condicionado a la potestad legislativa autonómica, ya que es competencia de éstas últimas, por razón de la materia $^{207}$.

Y lo que ha sido más trascendental y objeto de numerosos debates y foros de reivindicación: la Disposición Transitoria $4^{\mathrm{a}}$ recoge la previsión que si las ELM no rinden sus cuentas antes del 31 de diciembre de 2014 incurrirán en causa de disolución ${ }^{208}$. Medida considerada insuficiente y parcial puesto que se está poniendo el

\footnotetext{
206 MELLADO RUIZ, L. "Notas críticas sobre el anteproyecto de la Ley de Racionalización y Sostenibilidad de la Administración Local: entre la reforma y la intervención". Revista CEMCI. $N^{o} 17$. Oct.-Dic. 2012. Pág. 13: "La eficiencia prima de nuevo sobre la potestad genérica de autoorganización de la Administración Local." Si bien el autor entiende la medida justificada en crear solo lo necesario y adecuado.
}

\begin{abstract}
${ }^{207}$ MORELL OCAÑA, L. "Las entidades locales, elementos integrantes de la organización territorial del Estado y de las Comunidades Autónomas". Revista Española de Derecho Administrativo $n^{\circ} 55$. Madrid. 1987. Pág. 348: “... la incidencia sobre la propia estructura del régimen local constituya una característica competencia autonómica. No se trata tan solo de la habilitación constitucional para alterar la división en términos municipales sino, además, y siempre con el respeto a las entidades diseñadas a nivel básico, realizar los añadidos estructurales necesarios (entre ellas las EATIM)...”.
\end{abstract}

\footnotetext{
${ }^{208}$ Autores como GRACIA HERRERO afirman que la medida es inoperante y que no va a cambiar nada respecto de las ELM existentes, preocupándose únicamente de tener que presentar las cuentas a partir de ahora. op cit. pág. 541. Recordaremos que el primer borrador del ALRSAL establecía que todas las EATIM existentes a la entrada en vigor de la nueva ley se disolvían, sin conceder ningún plazo transitorio. Posteriormente las versiones que siguieron establecieron que no se disolvían sin más, si no que si no rendían sus cuentas en el plazo de tres meses desde la entrada en vigor de la nueva ley incurrirían en causa de disolución. Por último el texto normativo ha sido aprobado con el nuevo plazo de que se rindan cuentas antes del 31 de diciembre de 2014. MELLADO RUIZ, op cit, pág. 14, lo recogía planteando tres tipos de dudas que paso a exponer: el carácter genérico e incondicionado de la disposición- sin atender a las circunstancias específicas en cada caso-, el sentido de la operación de "disolución"-término extraño en nuestro Derecho de la organización, y ambiguo en cuanto a los efectos específicos de la auténtica "supresión legal", más que decisión individual, de las entidades locales- y, sobre todo, el choque con las competencias exclusivas autonómicas sobre desarrollo del régimen local y
} 
acento únicamente en el tema de la rendición de cuentas casi desde una visión puramente estadística, sin tener en cuenta si esas cuentas están debidamente fiscalizadas y/o realizadas, y que es una porción no determinante del campo de gestión del día a día de una ELM.

El incurrir en causa de disolución llevará parejo que sea la CA la que tome la iniciativa y posterior resolución de llevar a término dicha supresión, que ya se verá si finalmente se lleva a cabo. Desde luego la redacción de la DT $4^{\mathrm{a}}$ no parece ser muy afortunada y se ha perdido un momento oportuno para precisar con más detalle la regulación de ese "supuesto de disolución", el cual acarrea dos consecuencias trascendentales, como son:

- La incorporación directa del personal, si lo hubiere, al servicio de la ELM al Ayuntamiento al que pertenezca la misma, lo cual nos lleva a cuestionarnos los pretendidos efectos reductores o racionalizadores que persigue la propia ley;

- La subrogación por el Ayuntamiento de todos los derechos, obligaciones y bienes de la entidad disuelta, y aquí está el "quid” de la cuestión, puesto ¿qué va a pasar con aquellos bienes que tienen naturaleza comunal y que deberían ser únicamente para el común de los vecinos del núcleo de población que ha perdido su condición de ELM?.

Todo esto se verá con más detenimiento en el capítulo correspondiente a la problemática de la rendición de cuentas. Lo que sí podemos remarcar como positivo es que al menos se ha suprimido de los anteriores borradores la previsión de sometimiento a evaluación de la adecuación y eficiencia de los servicios mínimos prestados por las ELM, que en las versiones iniciales así venía recogido ${ }^{209}$.

\footnotetext{
la garantía mínima constitucional de reconocimiento de la autonomía (organizativa) local a las entidades municipales.

${ }^{209}$ Borrador Anteproyecto Versión 18 de febrero de 2013. Disposición adicional séptima. Evaluación de los servicios prestados por mancomunidades y entidades de ámbito territorial inferior al Municipio. 1. Cuando de la evaluación de los servicios prestados por una mancomunidad resulte la inadecuación de su prestación en el ámbito de la mancomunidad, corresponderá a las Diputaciones, Cabildos o Consejos Insulares la prestación de los referidos servicios y la mancomunidad quedará disuelta.

2. Cuando de la evaluación de los servicios prestados por las entidades de ámbito territorial inferior al municipio resulte la inadecuación de la prestación del servicio en su ámbito, corresponderá al municipio la prestación del mismo y la entidad de ámbito territorial inferior al municipio quedará disuelta.
} 
Otro aspecto que considero bastante negativo y que demuestra un desconocimiento absoluto de lo que implica la existencia de una ELM respecto del municipio en el que se integra es la previsión recogida en la LRSAL del nuevo art. 116 bis el cual establece que cuando un municipio incumpla con los objetivos de estabilidad presupuestaria, deuda pública o regla de gasto previstos en la LOEP, como medida a incluir en el Plan económico financiero a que está obligado a confeccionar debido a dichos incumplimientos, figura la posibilidad de suprimir a las ELM pertenecientes a su término municipal ${ }^{210}$ que, o bien incumplan asimismo los parámetros de estabilidad presupuestaria o deuda pública o superen el periodo medio de pago a proveedores, lo cual implica, no ya una conducta punitiva hacia la ELM sino que del comportamiento incumplidor del municipio lleve aparejada que la ELM se pueda suprimir como medida de saneamiento municipal.

Me parece preocupante cuanto menos el entendimiento al que ha llegado el legislador con esta cuestión, y extractaría unas conclusiones importantes:

- Si bien la ELM no cuenta con autonomía local reconocida constitucionalmente como sí se hace respecto del municipio, no es menos cierto que es una entidad local con personalidad jurídica independiente del mismo y que a éste no se le atribuyen por el ordenamiento jurídico competencias fiscalizadoras o de control respecto de sus ELM;

- Que no sólo se las hace copartícipes y casi culpables del incumplimiento de su ayuntamiento, sino que además parece jocoso que se prevea que se va a salvar un municipio que incurra en la falta de cumplimiento de las obligaciones derivadas de la estabilidad presupuestaria o de un excesivo endeudamiento, indicadores referenciados al presupuesto municipal y no al de la ELM, mediante la supresión de una entidad que tiene un presupuesto independiente y no vinculado al del ayuntamiento y que no afecta para nada a la gestión presupuestaria municipal, sino que además la supresión de una ELM para sanear

\footnotetext{
${ }^{210}$ Borrador Anteproyecto Versión 18 de febrero de 2013. Disposición adicional séptima. Evaluación de los servicios prestados por mancomunidades y entidades de ámbito territorial inferior al Municipio. 1 . Cuando de la evaluación de los servicios prestados por una mancomunidad resulte la inadecuación de su prestación en el ámbito de la mancomunidad, corresponderá a las Diputaciones, Cabildos o Consejos Insulares la prestación de los referidos servicios y la mancomunidad quedará disuelta.

2. Cuando de la evaluación de los servicios prestados por las entidades de ámbito territorial inferior al municipio resulte la inadecuación de la prestación del servicio en su ámbito, corresponderá al municipio la prestación del mismo y la entidad de ámbito territorial inferior al municipio quedará disuelta.
} 
un municipio que nada tiene que ver con ella es inverosímil por no decir otra cosa.

Si el redimensionamiento que se prevé para la administración local y la reducción de costes pasa por suprimir aquellas entidades más débiles y con menos recursos económicos, cuya desaparición apenas generará ahorro, es no haber entendido nada.

\section{5.- Resumen}

Como se puede extraer de todo el articulado de la LRSAL, esta reforma trata básicamente del desarrollo de la LOEP para su aplicación a la administración local. Se ha optado, en vez de regular y asegurar la suficiencia financiera del sector local tan demandada todos estos años, por una reducción competencial municipal y un refuerzo del papel de las Diputaciones Provinciales para asumir y atender los servicios locales de aquellos ayuntamientos que no los puedan realizar ${ }^{211}$. Si bien el tiempo nos dirá si las Diputaciones Provinciales finalmente van a aplicar esta norma y si por ello van a readaptar sus estructuras para garantizar la prestación efectiva de los servicios locales que se asuman como propios, porque por el momento parece como si nadie se creyera o se quisiera creer la obligatoriedad de esta ley. Es más, la norma ya está siendo revisada por el TC ya que algunas CCAA presentaron recursos contra la misma ${ }^{212}$.

\footnotetext{
${ }^{211}$ ORTEGA JIMENEZ, MP. "La normativa autonómica para garantizar la prestación de ciertos servicios por parte de las entidades locales en Castilla y León". El Consultor de los Ayuntamientos y de los juzgados $n^{\circ}$ 9. 2014 pág. 989: al caracterizarse los municipios de nuestra CA por su escaso tamaño y su dispersión territorial, dichas circunstancias condicionan las prestaciones de servicios, sobre todo en materia de salud y dependencia, existiendo en este momento fórmulas que coordinan la actuación de distintas administraciones y mantienen los costes en unas ratios por habitante que pueden ser asumidas. A tal efecto la autora cita la colaboración de las EATIM en materia de salud y sus actuaciones de mantenimiento y conservación de consultorios locales, con implicación de la propia población afectada en su ejercicio, son fundamentales en relación con la sostenibilidad del sistema.
}

212 BOE 31 de mayo de 2014 admisión a trámite del recurso de inconstitucionalidad del Parlamento Andaluz contra la http://politica.elpais.com/politica/2014/09/11/actualidad/1410449272_836539.html (11.09.2014) El Tribunal Constitucional ha admitido a trámite la demanda de cerca de 3.000 Ayuntamientos de toda España, que representan a unos 17 millones de ciudadanos en contra de la reforma local impulsada por el Gobierno del PP. El recurso critica que la reforma impulsda por el Gobierno no respete "la configuración constitucional de la autonomía local" y el hecho de que cree "dos clases de municipios, los grandes y los de menos de 20.000 habitantes, abocados a convertirse en meros foros de discusión política sin capacidad de gestionar servicios", tal como señala el texto que señala además que el cambio legislativo persigue desapoderar "a los pequeños y establecer controles de oportunidad por parte de otras administraciones que sitúan a las entidades locales en posición de subordinación". PSOE, PSC, Izquierda Plural (IU, ICV, 
Que la reforma era necesaria ${ }^{213}$ y se debía acometer, era indudable, pero se ha visto que una vez tomada la decisión de hacerlo no se ha llevado a cabo con un apoyo significativo por parte de los sujetos afectados. Se ha cuestionado que en la elección de la solución adoptada no se haya tenido en cuenta las consecuencias de desnaturalización del municipio ${ }^{214}$, sobre todo en Comunidades Autónomas como Castilla y León con un elevado número de ayuntamientos de muy baja población, donde a largo plazo los supuestos de concentración provincial (o mancomunada, según la LORSEGO) podrían llegar a generalizarse si de verdad esta ley cristaliza.

De hecho la Junta de Castilla y León, al haber aprobado la LORSEGO dos meses antes de la aprobación de la LRSAL, se apresuró a disponer de un "Informe sobre la incidencia de la Ley 27/2013 en la Ley 7/2013 de ordenación del territorio", el cual pretende justificar la compatibilidad de ambas leyes. Informe que, careciendo de fecha, está realizado por Letrado de la Consejería de Presidencia, y respecto del mismo remarco el párrafo en el que dice: "Que las dos leyes tengan filosofías distintas y se muevan en planos diferentes facilita una interpretación tanto literal como teleológica que hace posible su aplicación sin interferencias mutuas y plenamente compatibles". ¿De verdad tenemos que creer o aceptar esta aseveración?. No es que ambas normas se muevan en planos diferentes, es que, en mi opinión, una no encaja en la otra. ¿Cómo no se esperó a aprobar y publicar la ley autonómica a que se aprobara la versión definitiva de la ley estatal, aspecto que se produjo a los dos meses?.

CHA), BNG, CiU, ERC y UPyD fueron los partidos promotores del recurso admitido a trámite que se une a los presentados y admitidos por los Parlamentos de Extremadura, Cataluña y Navarra, los gobiernos autonómicos de Andalucía, Asturias, Cataluña y Canarias. Solo quedaron al margen los parlamentarios del PP, del PNV --que apoyó la reforma local en su tramitación en las Cortes Generales--, CiU --que presentó recurso desde el Gobierno y el Parlamento catalán-- y varias formaciones del Grupo Mixto.

El Constitucional ha dado traslado del conflicto en defensa de la autonomía local presentada contra la Ley de Racionalización y Sostenibilidad de la Administración Local al Congreso de los Diputados, al Senado y al Gobierno, que disponen ahora de 20 días para personarse en el procedimiento y formular alegaciones.

La admisión a trámite, según recuerda el tribunal en una nota, no supone pronunciamiento alguno sobre el fondo del asunto. Además, en respuesta a la petición de suspensión cautelar de la reforma local realizada por los Ayuntamientos, el pleno del tribunal ha acordado dar un plazo de 15 días a las partes para que se pronuncien al respecto.

${ }^{213}$ Vid. RIVERO ORTEGA, R. “Alteraciones de la planta municipal y reinvención de las Diputaciones" Revista de estudios locales CUNAL, $n^{\circ}$ 169. 2014. Pág. 64.

${ }^{214}$ SALVADOR CRESPO, M "Las competencias de las Diputaciones Provinciales en la Ley 27/2013". Cuadernos de Derecho Local n ${ }^{\circ}$ 34. Pág. 143, señala la autora que mientras en Europa se está apostando por una reducción del número de municipios, por redefinir las funciones de las entidades supramunicipales para suprimirlas y/o reducirlas, y por reforzar la autonomía local de los municipios, las previsiones de la LRSAL van por otros derroteros", ya que el número de municipios no se reduce pero sí se reducen sus competencias. 
Además debo apuntar que Castilla y León se ha decantado y posicionado por aprobar una normativa de desarrollo para la aplicación de la LRSAL para garantizar que los servicios sigan llegando a los ciudadanos, y solventando la incertidumbre jurídica en relación con la atribución competencial, pero sin aclarar si la reforma tendrá finalmente el efecto de reducción de gasto público esperado por el legislador nacional ${ }^{215}$. Así las cosas se aprobó el Decreto Ley 1/2014, de 27 de marzo, de medidas urgentes para la garantía y continuidad de los servicios públicos en Castilla y León, y la Circular de 1 de abril de 2014, de la Viceconsejera de Administración y Gobierno del territorio relativa al sistema competencial y otras cuestiones derivadas de la entrada en vigor de la LRSAL. De este modo esta normativa de desarrollo considera que el listado de materias que recoge el art. 25.2 LRBRL es abierto, de manera que las entidades locales pueden tener competencias propias en otras materias diferentes de las señaladas en la norma básica, siempre que su atribución sea a través de una ley autonómica sectorial, posición criticada tanto por el Consejo de Estado como por parte de la doctrina y que yo comparto, pues el espíritu de la ley, mal que nos pese, es precisamente ese, recortar o enmarcar las competencias municipales, no dejarlo todo como está, que es lo que parece que quieren hacer las Comunidades Autónomas con las normativas que está siendo aprobadas. Nadie parece querer aplicar dicha ley ${ }^{216}$. Además esa normativa no aborda

\footnotetext{
${ }^{215}$ Otras CCAA también han seguido esta pauta, tales como Galicia (Ley 5/2014), Andalucía (Decreto ley 7/2014), Cataluña con el Decreto Ley 3/2014 de 4 de junio (no convalidado en el Parlamento y por lo tanto ya derogada), Decreto Ley 1/2014, de 27 de junio de Murcia, y la Ley 1/2014, de 25 de julio de Madrid, y esta práctica no deja de ser sorprendente, en palabras de ZAFRA VICTOR, M. "Sorprendente normativa autonómica para el desarrollo de la Ley 27/2013...": "lo que pretenden no es un desarrollo singularizado de la ley sino también descartar una interpretación propuesta por el Consejo de Estado". Y de ese modo, el Consejo de Estado en su Dictamen 338/2014, (en virtud de los recursos de inconstitucionalidad interpuestos por el Ayuntamiento de Barcelona), en sintonía con el Dictamen 567/2013 (éste ya visto sobre la tramitación del anteproyecto de la LRSAL), asevera que la LRSAL pretende evitar que las leyes sectoriales del Estado o de las CCAA atribuyan competencias a los municipios al margen del mecanismo de la delegación del art. 27 LRBRL, en materias distintas de las enumeradas por el art. 25.2 de la misma norma. De tal propósito resulta ejemplarizante que se suprimiera, en el informe de la Ponencia del Senado, el apartado 6 del art. 25 LRBRL en el que se habilitaba a las CCAA para atribuir a los municipios competencias propias en materias distintas de las previstas en el apartado 2 de dicho precepto y concluye que el listado del art. 25.2 es un listado cerrado.
}

${ }^{216}$ COOLS. M./VERBEEK L. "Democracia local y regional en España". The Congress of Local and Regional Authorities. Bruselas. Febrero. 2013. pág. 24 es interesante este informe que ya da signos relevantes de la situación en que se encuentra inmersa la Administración Pública española al afirmar "que el Gobierno no ha proporcionado un mecanismo para superar el desequilibrio causado por el ejercicio de determinadas competencias de los gobiernos locales, que tradicionalmente se han venido prestando, debido a su proximidad a los ciudadanos y en respuesta a sus demandas directas. Estas "competencias impropias" no están reguladas por la legislación y la prestación de servicios que implican estas competencias, no cuenta con recursos económicos para su ejecución". Afirma este Informe que la legislación española se debe modificar no solo de acuerdo con el principio de subsidiariedad, sino también el principio de "singularidad". La evitación de las superposiciones de competencias se considera que es un medio crucial para salvar los recursos públicos". 
cuestiones tales como la relativa a las prestaciones previas a la reforma local no amparadas en este momento por una atribución competencial propia o delegada ${ }^{217}$.

${ }^{217}$ Cuestión que en otras CA como Canarias o País Vasco sí se ha abordado a través de las Circulares de 31 de marzo de 2014 y 11 de marzo de 2014 respectivamente, las cuales consideran que en ese caso las prestaciones pueden continuar sin que sea necesario solicitar ninguna autorización por parte de la entidad local, criterio por otra parte contrario al que sostiene el ministerio en su documento técnico informativo: http://minhap.gob.es/Documentacion/Publico/PortalVarios/Gesti\%20del\%20Portal/nota\%20explicativa\% 20de\%20la\%20reforma\%20local.pdf. 
Tabla: COMPETENCIAS DE LAS EE.LL DESPUÉS DE LAS ADAPTACIONES AUTONÓMICAS

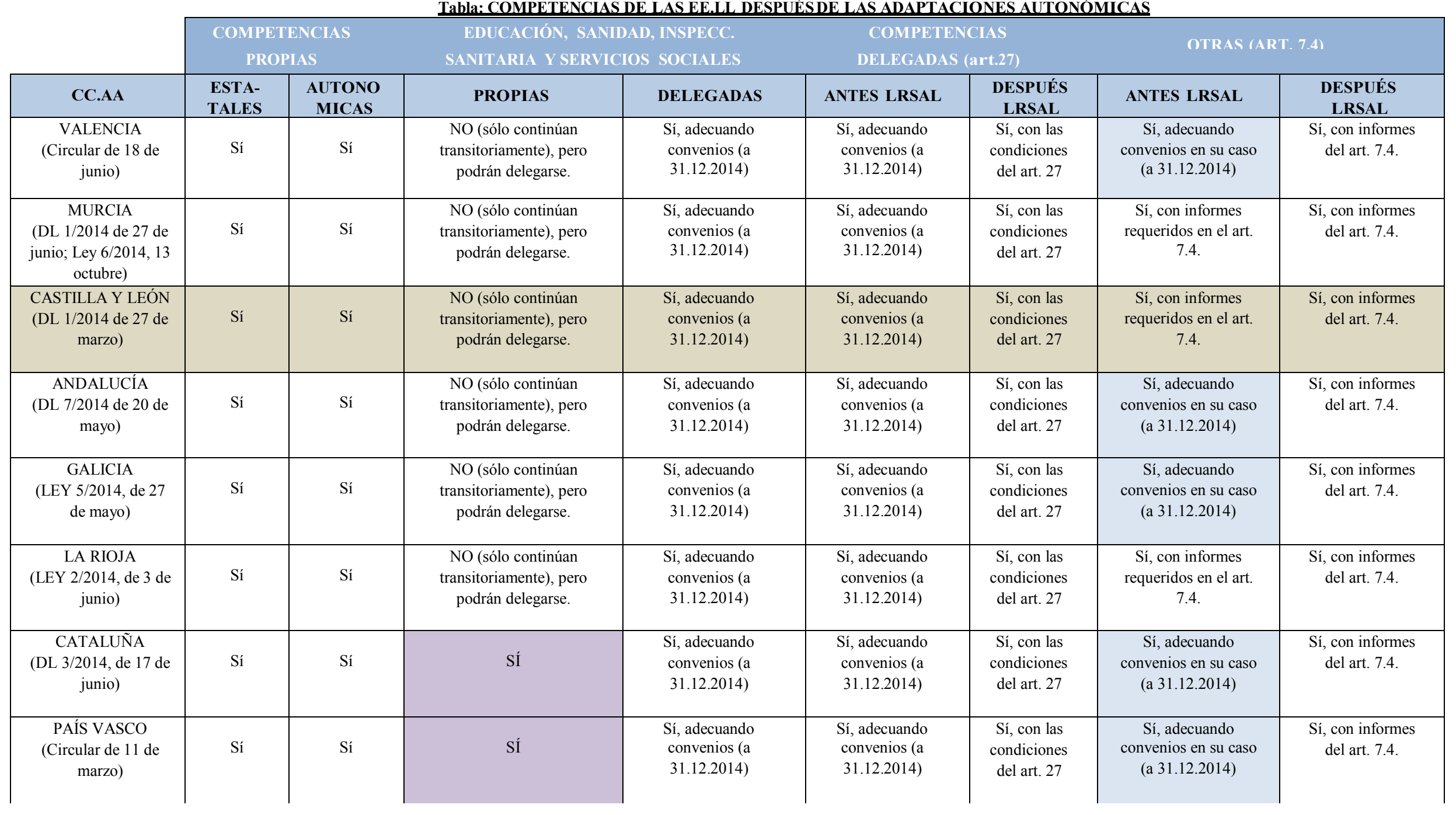




\begin{tabular}{|c|c|c|c|c|c|c|c|c|}
\hline $\begin{array}{c}\text { ARAGÓN } \\
\text { (Circular de } 28 \text { de } \\
\text { abril) }\end{array}$ & Sí & Sí & SÍ & $\begin{array}{c}\text { Sí, adecuando } \\
\text { convenios (a } \\
31.12 .2014)\end{array}$ & $\begin{array}{l}\text { Sí, adecuando } \\
\text { convenios (a } \\
31.12 .2014)\end{array}$ & $\begin{array}{l}\text { Sí, con las } \\
\text { condiciones } \\
\text { del art. } 27\end{array}$ & $\begin{array}{l}\text { Sí, con informes } \\
\text { requeridos en el art. } \\
7.4 .\end{array}$ & $\begin{array}{l}\text { Sí, con informes } \\
\text { del art. 7.4. }\end{array}$ \\
\hline $\begin{array}{c}\text { MADRID } \\
(1 / 2014, \text { de } 1 \text { de } \\
\text { julio })\end{array}$ & Sí & Sí & $\begin{array}{l}\text { NO (sólo continúan } \\
\text { transitoriamente), pero } \\
\text { podrán delegarse. }\end{array}$ & $\begin{array}{c}\text { Sí, adecuando } \\
\text { convenios (a } \\
31.12 .2014)\end{array}$ & $\begin{array}{c}\text { Sí, adecuando } \\
\text { convenios (a } \\
31.12 .2014)\end{array}$ & $\begin{array}{c}\text { Sí, con las } \\
\text { condiciones } \\
\text { del art. } 27\end{array}$ & $\begin{array}{l}\text { Sí, con informes } \\
\text { requeridos en el art. } \\
7.4 .\end{array}$ & $\begin{array}{c}\text { Sí, con informes } \\
\text { del art. 7.4. }\end{array}$ \\
\hline $\begin{array}{l}\text { ASTURIAS } \\
\text { (D. } 68 / 2014 \text { de } \\
10 \text { de julio) }\end{array}$ & Sí & Sí & $\begin{array}{l}\text { NO (sólo continúan } \\
\text { transitoriamente), pero } \\
\text { podrán delegarse. }\end{array}$ & $\begin{array}{c}\text { Sí, adecuando } \\
\text { convenios (a } \\
31.12 .2014 \text { ) }\end{array}$ & $\begin{array}{l}\text { Sí, adecuando } \\
\text { convenios (a } \\
31.12 .2014)\end{array}$ & $\begin{array}{l}\text { Sí, con las } \\
\text { condiciones } \\
\text { del art. } 27\end{array}$ & $\begin{array}{l}\text { Sí, adecuando } \\
\text { convenios en su caso } \\
\text { (a 31.12.2014) }\end{array}$ & $\begin{array}{l}\text { Sí, con informes } \\
\text { del art. 7.4. }\end{array}$ \\
\hline
\end{tabular}

Sí = continúa la competencia. No = no continúa la competencia. 
Y respecto de la regulación que se hace de las ELM, opino que no se ha optado por la mejor solución, ya que, si bien es verdad que era necesario exigir a estas entidades un control de sus cuentas y una previsión de intervención, no es menos cierto que parece desproporcionado imponer a las CCAA la disolución de dichos entes locales, y no de todas, porque si bien mi opinión pasa porque entiendo que la aplicación de la LRSAL será una medida para poder poner en su debido lugar a cada una de las ELM, es decir, para acreditar que pervivan aquellas que verdaderamente tienen una madurez organizativa y económica suficiente, no menos cierto es que una vez suprimidas ya no existe previsión de resurrección de las personificación de las mismas y no se permite ya a las CCAA la creación de nuevos entes infralocales ${ }^{218}$.

Así las cosas y sistematizando los aspectos más críticos de la LRSAL respecto de estos entes, señalaría:

- Que se crea con tal regulación una dualidad diferenciada de organizaciones (ya que pueden pervivir las que mantienen su personalidad jurídica y las que no), y esto traerá efectos jurídicos diferentes.

- La técnica legisladora adolece de ciertos errores. No se ha modificado por el legislador el art. 4.2. ${ }^{219} \mathrm{Ni}$ tampoco se ha modificado el art. 47.2, al referirse al quórum especial de votación, sigue haciendo referencia a la creación, modificación y supresión de las entidades del art. 45 (el cual ya hemos visto que ha sido derogado). Tampoco se han derogado los artículos 38 a 45 del TRRL.

- La regulación de la causa de supresión prevista en la Disposición Transitoria $4^{\mathrm{a}}$ en el supuesto de no rendición de cuentas es imprecisa y causa inseguridad jurídica, puesto ¿a qué cuentas nos estamos refiriendo?, este cuestión ha sido recientemente solventada en una reunión que ha tenido lugar el 19 de septiembre de 2014 entre la Secretaria General de Coordinación Autonómica y Local del Ministerio de Hacienda y los representantes de la Federación de Concejos, Pedanías y Parroquias Rurales de España donde se manifestó el criterio del Ministerio de que rindiendo las cuentas del ejercicio 2013 se evitaría la supresión que impone la

\footnotetext{
218 TOLIVAR ALAS; L. "Las entidades inframunicipales", en "La reforma del régimen local". Tirant Lo Blanch 2014. pág. 403.

219 TOLIVAR ALAS, L. op cit. pág. 386, critica mucho esta circunstancia llamando a la situación de quiasiesperpéntica, puesto que si ya no son administración pública estas entidades, ¿cómo van a gozar de potestades y privilegios exorbitantes?.
} 
DT4 ${ }^{\mathrm{a}}$ de la LRSAL". ${ }^{220}$ Pero, de esas cuentas, ¿ante qué organismos?, puesto que existe la obligación de rendir no solo la Cuenta General ante el Consejo de Cuentas de Castilla y León, aspecto en el que se está haciendo más hincapié, sino que también esas cuentas se deben presentar ante el MINHAP junto con la liquidación presupuestaria, que a su vez se tiene que presentar ésta última ante la comunidad autónoma, así que esperemos que ante este entresijo de presentación de obligaciones, y falta de coordinación, no resulte perjudicial para las entidades cumplidoras.

- La desafortunada previsión de supresión de las ELM recogida en el art. 116 bis en el caso de que el municipio al que pertenezca no cumpla con los objetivos de estabilidad presupuestaria, regla de gasto o límite de endeudamiento, que hace depender el futuro de una entidad del incumplimiento de otra, de la que ambas tienen personalidades jurídicas diferentes y presupuestos independientes.

Que las ELM que tengan medios y capacidad, es decir, las que acrediten su grado de madurez y capacidad, deben existir, esa es nuestra postura, pero paralelamente deben adecuarse en cada municipio las fórmulas quizás autoritarias que obliguen al funcionamiento eficaz de tales entidades, en una conexión racional de la actividad de las mismas y la de sus municipios.

${ }^{220} \mathrm{http}: / /$ concejos.org 
III. LA PROBLEMÁTICA CON EL DESEMPEÑO DE LAS FUNCIONES DE SECRETARÍA

\section{1.- LA REGULACIÓN DE LAS FUNCIONES DE SECRETARIA EN LAS ENTIDADES LOCALES MENORES}

Para comenzar a abordar la problemática objeto de este capítulo, me gustaría empezar por los antecedentes ${ }^{221}$ normativos más recientes sobre el tema hasta llegar a la regulación actual, causada tanto por la nueva LRSAL como por la situación generada en Castilla y León al respecto ${ }^{222}$. Para ello se acude, en primer lugar, a lo previsto en la legislación estatal, y en concreto a la Disposición Transitoria $3^{\mathrm{a}}$ del Real Decreto Legislativo 781/1986, de 18 de abril por el que se aprueba el Texto Refundido de Régimen Local (TRRL), el cual y manteniendo el criterio vigente en ese momento, establecía en su $n^{\circ} 3$ que, hasta que se desarrollara reglamentariamente el régimen estatutario de los funcionarios con habilitación de carácter nacional (FHN), la secretaría de las EATIM correspondería a quien desempeñase la del Ayuntamiento o agrupación a que pertenecieran aquellas.

\footnotetext{
${ }^{221}$ Ya en la normativa preconstitucional apenas se recogía mención a la cuestión a suscitar de la figura del secretario en las entidades locales menores. RUIZ RODRIGUEZ ob cit. pág. 52, lamenta que la ley no dedique ni siguiera una línea a la cuestión planteada en este capítulo y afirma con gran acierto que es precisamente del Secretario de quien depende el buen o mal funcionamiento de la Junta Vecinal. El art. 98.2 del Reglamento de Organización de 1955 señalaba ya que en las entidades locales menores cuya población inferior a 500 habitantes, podría habilitarse a una persona apta y de reconocida probidad que, teniendo la condición de vecino, desempeñe el cargo de Secretario. Y el art. 130.2 del Reglamento de Funcionarios de Administración Local de 1952 exceptuaba de la obligatoriedad de sostener Secretario de los Cuerpos Nacionales a las entidades locales menores que, por no poder mantener la plaza, habiliten circunstancialmente a un vecino apto y de reconocida probidad para el desempeño de tal cargo. Cierto es que el art. 136.3 del citado Reglamento de 1952 previene que los habilitados como Secretarios de ELM "actuarán bajo la superior orientación y fiscalización del Secretario del Municipio a que pertenezcan" y a quien incumbe proponer su nombramiento como recogía la Circular de la Dirección General de Administración Local de 11 de febrero de 1953, y que señalaba también la retribución correspondiente a su función asesora (nueve pesetas por habitante para el Secretario de la Junta y cuatro pesetas por habitante para el Secretario del Ayuntamiento por su función asesora, y sin que el conjunto de los emolumentos de uno y otro pueda exceder de quince pesetas por habitante y año). Pero parece que con ello no quedaba satisfecho el buen servicio administrativo de la ELM, pues como afirma el autor: "la experiencia nos muestra los escasos resultados prácticos de tal sistema, ya que el Secretario del Municipio matriz, aparte de no disponer del tiempo preciso para ocuparse de la actividad asesora que le impone la ley respecto del submunicipio, es considerado en éste, si no como un intruso que se interfiere, a favor del Ayuntamiento, en el interesado mangoneo de la Junta, al menos como un testigo molesto".
}

${ }^{222}$ LAZO VITORIA, S. "El estatuto de los FHE y algunas reflexiones en torno al control económicofinanciero en el ámbito local". Revista española de Derecho Administrativo $n^{\circ}$ 141. 2009. "Es lugar común señalar que los Cuerpos Nacionales de Administración Local creados al amparo de los Estatutos Municipal y Provincial de Calvo Sotelo son el antecedente directo de los actuales FHE”. 
Con posterioridad se aprobó el desarrollo reglamentario de dicha norma en ese ámbito, a través del Real Decreto 1174/1987, de 18 de septiembre, de régimen jurídico de los funcionarios de administración local con habilitación de carácter nacional, y concretamente para los puestos de secretaría en la sección $2^{\mathrm{a}}$ del Capítulo II, Título I, así como en su Disposición Transitoria $2^{\mathrm{a}}$; pero en ningún momento se hace indicación expresa al asunto de las EATIM $^{223}$.

En este orden de cosas, el derogado artículo 9 del Real Decreto 1174/1987 recogía una previsión interesante de aplicar ante el vacío de regulación en este asunto, la cual consistía en que aquéllas entidades cuya población y recursos ordinarios no superasen las cifras que determinara el Ministerio de Administraciones Públicas (500 habitantes y 7 millones de pesetas de presupuesto según la Resolución de la Dirección General de la Función Pública de 24 de noviembre de 1987), podrían ser eximidas de la creación del puesto de secretaría, siendo en tales casos ejercidas dichas funciones en la forma establecida en los artículos 10 y 11 de la norma. Pero estos artículos a su vez fueron derogados y el tema referente a las posibles exenciones de los puestos de trabajo reservados a FHE quedó, tal y como está en la actualidad recogida en el art. 4 del Real Decreto 1732/1994, de 29 de julio sobre provisión de puestos de trabajo de FHN, el cual dice así: "Las entidades locales con población inferior a 500 habitantes y presupuesto inferior a 20.000.000 pesetas podrán ser eximidas por la Comunidad Autónoma, previo informe de la Diputación Provincial, Cabildo o Consejo insular, de la obligación de mantener el puesto de trabajo de secretaría, en el supuesto de que no fuese posible efectuar la agrupación prevista en el art. 3 a) del mismo Real Decreto.

Las funciones atribuidas al puesto suprimido serán ejercidas por alguno de los sistemas establecidos en el art. 5 (servicios de asistencia) o 31.2 (acumulaciones) del Real Decreto.

\footnotetext{
${ }^{223}$ La Sección $2^{\text {a }}$ fue derogada por el Real Decreto 731/1993, de 14 de mayo, exceptuando los artículos 8 y 13.2. Por su parte el Real Decreto 731/1993, de 14 de mayo fue derogado por el Real Decreto 1732/1994, de 29 de julio. Así vemos el artículo 8 dice: "En todas las Corporaciones Locales existirá un puesto de trabajo denominado Secretaría, al que corresponde la responsabilidad administrativa de las funciones de fe pública y asesoramiento legal preceptivo, con el alcance y contenido previsto en este Real Decreto".

Y el artículo 13.2: "Las funciones de fe pública y asesoramiento legal preceptivo, recogidas en los artículos 2 y 3 y concordantes de este Real Decreto, respecto de Juntas, órganos o entidades dependientes de la Corporación distintas del Alcalde, Pleno o Comisión de Gobierno decisoria, podrán ser encomendadas por la Corporación a funcionarios propios de la misma carentes de la habilitación de carácter nacional, a propuesta del titular de la Secretaría, y que actuarán como delegados de éste".
} 
Asimismo y por igual procedimiento, las Mancomunidades de Municipios o Comunidades de Villa y Tierra podrán ser eximidas de la obligación de mantener puestos propios reservados a habilitados de carácter nacional cuando su volumen de servicios o recursos sea insuficiente para el mantenimiento de dichos puestos $[\ldots]^{224}$.

A fin de garantizar el ejercicio de las funciones reservadas, en el expediente de exención se concretará el sistema elegido". De este modo esta posibilidad de exención, y a mayor abundamiento, de llevanza de los puestos de secretaría en las EATIM por algunas de las herramientas o fórmulas recogidas en la normativa aplicable (ya sea mediante nombramiento en acumulación o a través de los funcionarios con habilitación de carácter estatal adscritos a los Servicios de Asistencia y/o Asesoramiento a Municipios SAM/SAT- de las Diputaciones Provinciales) están previstas de manera única para los municipios $^{225}$, no pudiéndose disociar el puesto de secretario municipal de la llevanza de la secretaría de las $\mathrm{ELM}^{226}$.

Posteriormente, la Disposición Adicional Segunda de la Ley 7/2007, de 12 de abril del Estatuto Básico del Empleado Público $\left(\mathrm{EBEP}^{227}\right)$ contemplaba ${ }^{228}$ como funciones públicas necesarias, en todas las Corporaciones Locales, la de secretaría, comprensiva de la fe pública y el asesoramiento legal preceptivo, así como la de control y fiscalización interna en la gestión económico-financiera y presupuestaria y la contabilidad, tesorería y

\footnotetext{
${ }^{224}$ Las funciones reservadas a habilitados nacionales en Mancomunidades de Municipios o Comunidades de Villa y Tierra se ejercerán a través de funcionario/s con habilitación de carácter nacional de alguno de los municipios que las integran o por algunos de los sistemas del art. 5 (servicios de asistencia) o art. 31.2 (acumulaciones).

${ }^{225}$ Vid. Informe Gabinete Técnico FEMP 26 de septiembre de 1991, el cual señala claramente que: [...] el sostenimiento en común mediante agrupación, de un puesto único de secretaría, así como el ejercicio de tales funciones por funcionarios con habilitación de carácter nacional adscritos a los Servicios de Asistencia existentes en las Diputaciones Provinciales cuando no se produjese la agrupación, están referidos exclusivamente a Municipios en sentido estricto [...].

${ }^{226}$ Cfr. El Informe FEMP 1991 arriba indicado afirma a su vez que no tiene sentido el separar mediante agrupación de puestos de trabajo el correspondiente a la secretaría municipal y el de las ELM, pues ambos se pertenecen y se complementan, y el puesto de Secretaría conlleva el del desempeño de dichas funciones en las ELM existentes en el término municipal.

227 SERRANO PASCUAL, A. "El régimen jurídico de los funcionarios con habilitación estatal". El Consultor de los Ayuntamientos. $n^{\circ}$ 24. 2008, pág. 4117: Con el EBEP se ha producido una mayor interiorización autonómica. Vid. TOLIVAR ALAS, L. "El personal de la administración local y el nuevo marco regulador de la función pública" Revista de estudios locales y autonómicos $n^{\circ} 308$. 2008. Pág. 43-46.

${ }^{228}$ Esta regulación ha sido derogada por la LRSAL 27/2013, recuperando la denominación de cuerpo de habilitación nacional y no estatal y el encaje de dicha normativa de nuevo en la LRBRL y no ya en el EBEP.
} 
recaudación, debiendo existir un puesto de trabajo que tenga atribuida la responsabilidad administrativa de dicha función.

Estas funciones públicas son asignadas a los funcionarios pertenecientes al Cuerpo de funcionarios de administración local con habilitación de carácter estatal - FHE - (antes de habilitación de carácter nacional) en sus diferentes escalas y subescalas. Sabido es que el régimen jurídico de los mismos actualmente lo conforma, a parte de la regulación prevista en el EBEP anteriormente citado, y mientras no exista desarrollo normativo del mismo o se produzca algún que otro cambio normativo, en principio, el Real Decreto 1174/1987 que hemos citado. Por otra parte el Real Decreto 1732/1994, de 29 de julio, sobre provisión de puestos de trabajo reservados a los funcionarios de administración Local con habilitación de carácter nacional, en vigor conforme la Disposición Transitoria $7^{\mathrm{a}}$ del EBEP, en relación con la Disposición Final $4^{\mathrm{a}}$ de dicho texto legal, completa el régimen jurídico en esta materia, y es consciente de la problemática de muchos municipios por la escasez de población y recursos, en el mantenimiento de los puestos de trabajo reservados al cuerpo de habilitados estatales, contemplando la posibilidad de que la Comunidad Autónoma acuerde la creación de agrupaciones de municipios al efecto de sostenimiento en común de dichos puestos de trabajo.

Siguiendo con la normativa aplicable a este cuerpo de funcionarios, la regulación de los puestos de secretaría en las ELM, viene recogida como hemos visto y ya de manera específica, en primer lugar, en el art. 8 del citado Real Decreto 1732/1994, el cual dispone que $^{229}$ : "El desempeño de las funciones de Secretaría en las Entidades de ámbito territorial inferior al municipio que gocen de personalidad jurídica se efectuará en los términos que establezca la normativa especifica que les sea de aplicación. En su defecto, corresponderá al Secretario del municipio a que pertenezca, a funcionario de la Corporación o a cualquier otra persona con capacitación suficiente, por el orden indicado. Asimismo, a instancia de la Entidad, podrá clasificarse como puesto independiente por el órgano competente de la Comunidad Autónoma respectiva ${ }^{230 ~ ", .}$

\footnotetext{
${ }^{229}$ El derogado artículo 161 del TRRL 781/1986 afirmaba que: "en todas las entidades locales existirá, al menos, un puesto de trabajo que tenga atribuida la responsabilidad administrativa de la función a que se refiere el artículo 92.3 a) de la Ley 7/1985, de 2 de abril”.

${ }^{230}$ A tal efecto resulta ilustrativo el dictamen del Consell de les Illes Balears de 25 de noviembre de 1999, en el que se plantea un procedimiento de revisión de oficio para declaración de nulidad de un acuerdo por el que se clasificaba por la CA un puesto independiente de secretaría intervención en una ELM, deviene nulo
} 
Descendiendo al ámbito autonómico, y en concreto en el ámbito de Castilla y León, la regulación se completa con la Disposición Adicional 6 a de la Ley 1/1998, de 4 de junio de Régimen Local de Castilla y León" ${ }^{231}$, la cual afirma que: "Las funciones de secretaría en las entidades locales menores serán desempeñadas por el Secretario del Ayuntamiento del municipio a que pertenezcan o por el servicio que con tal fin tenga establecido cada Diputación Provincial, en los términos que reglamentariamente se determinen $^{232, "}$. Pero ese desarrollo reglamentario se ha demorado y durante este largo tiempo de espera no han sido pocos los problemas para poder encajar y desempeñar dichas funciones.

Por lo tanto y según la normativa legal vigente hasta el momento el desempeño de la secretaría de las Entidades Locales Menores le correspondería al secretario del Ayuntamiento, así lo afirmó de manera bastante rotunda el TSJ de Castilla y León en sentencia 226/2011, de 6 de mayo, en la que se decía que: “... debe ser el Secretario del Ayuntamiento prioritariamente, definiéndose como el "sistema normal de funcionamiento de la secretaría de las ELM", y que el servicio que a tal efecto pueda tener la Diputación Provincial creado depende del desarrollo reglamentario, "se trata de un servicio de apoyo y colaboración no tan permanente, estructural y periódico, sino más puntual y coyuntural". Continua la sentencia diciendo: "no debemos olvidar que la D.A. $\sigma^{a}$ de la Ley 1/1998 no contempla nada más que dos vías, así la prestación de las funciones de secretaría por el Secretario del Ayuntamiento a que pertenezca la ELM o por el servicio

por haber omitido el procedimiento correspondiente y ser de contenido imposible dicha resolución ya que no se había creado en plantilla la referida plaza, ya que la legal existencia de la plaza de secretaría de la ELM no se cubre con el simple acuerdo de afirmar su creación y dotación presupuestaria, si no que exige, inexcusablemente, la inclusión de aquella en la correspondiente plantilla.

${ }^{231}$ El Informe del Procurador del Común de Castilla y León de 12 de julio de 2010 recoge entre otros pronunciamientos, el parecer de la Consejería de Presidencia de la Junta de Castilla y León de considerar la Ley 1/1998, de 4 de junio, de Régimen Local de Castilla y León, "como normativa específica que les sea de aplicación", a la que hace referencia el artículo 8 del Real Decreto 1732/1994.

${ }^{232}$ Debemos puntualizar que, si bien se habla en la Ley 1/1998, de 4 de junio de régimen local de Castilla y León de las funciones de secretaría, cierto es también que el Real Decreto 1174/1987, de 18 de septiembre, señala en su art. 14.2 que, en las corporaciones locales cuya secretaría esté clasificada en tercera clase, las funciones propias de la intervención formarán parte del contenido del puesto de secretaría, salvo que se agrupen a efectos de intervención.

Importante apreciación que quiero resaltar, ya que nos encontramos con supuestos de llevanza de las funciones de secretaría, mayoritariamente en municipios de menos de 5.000 habitantes y por lo tanto, donde las funciones de secretaría e intervención se desempeñan de forma conjunta, pero que existen supuestos de existencia de entidades locales menores en municipios con población igual o inferior a 20.00 habitantes y de más de 20.000 habitantes donde las funciones de secretaría e intervención-tesorería están separadas. 
que con tal fin tenga establecido cada Diputación, pero no contempla la prestación de dichas funciones por otras personas con capacitación".

\section{2.- DESEMPEÑO DE FUNCIONES DE SECRETARÍA Y SU PROBLEMÁTICA}

Vista la situación normativa anterior, se planteaba el problema ante el que se encontraban los secretarios locales del desempeño de estas funciones, acuciado en aquellos municipios con un elevado número de entidades locales menores, los cuales se ven desbordados en su labor; pero también el problema de la llevanza por parte de las Diputaciones Provinciales a través de sus oficinas de los SAM, ya que en mi opinión plantea la siguiente cuestión: ¿qué dimensión tendrán que tener estos servicios, sobre todo en los casos de provincias como Palencia, León y Burgos $^{233}$ ?.

Sin querer ser exhaustiva ni taxativa, hay que recordar que son funciones públicas cuyo cumplimiento queda reservado exclusivamente a personal sujeto al estatuto funcionarial, las que impliquen ejercicio de autoridad, las de fe pública y asesoramiento legal preceptivo, las de control y fiscalización interna de la gestión económico financiera y presupuestaria, las de contabilidad y tesorería y, en general, aquellas que, en desarrollo se reserven a los funcionarios para la mejor garantía de la objetividad, imparcialidad e independencia en el ejercicio de la función. Y en concreto y en todas las corporaciones locales, como hemos visto, funciones reservadas a funcionarios con habilitación de carácter estatal:

- la de Secretaría ${ }^{234}$, comprensiva de la fe pública y el asesoramiento legal preceptivo.

- el control y fiscalización interna de la gestión económica financiera y presupuestaria y la contabilidad, tesorería y recaudación.

\footnotetext{
${ }^{233}$ Cfr. Informe FEMP 1991: “...Piénsese en la dimensión que deberían tener los respectivos Servicios de Asistencia para cubrir las necesidades tanto de las propias Entidades inframunicipales como de los municipios eximidos de la creación del puesto de Secretaría".

${ }^{234}$ GARCIA GIL, F.J. “La función de secretaría en los ayuntamientos” Ed. La Ley El Consultor. Madrid 2011. Pp. 5: dentro de las funciones de secretaría, la comprensiva de la fe pública abarca funciones diversas, y la de preparación de los asuntos de obligatoria inclusión en el orden del día de las sesiones de los órganos colegiados desborda o trasciende lo que puede entenderse como fe pública en sentido estricto (acción de autorizar o legalizar alguna cosa para que sea auténtica con arreglo a derecho) para participar de las características de la función asesora.
} 
Es decir, un secretario en una ELM tiene las mismas funciones que en un municipio, sin perjuicio del diferente ámbito competencial de una y otro. Y así, desde el año 1.998 se estaba inmerso en esta problemática de falta de desarrollo reglamentario y precisión en cuanto a este problema de llevanza y/o reparto de funciones de los puestos de secretaría, y con varias dudas o lagunas interpretativas al respecto: ¿quién abona las retribuciones por los servicios prestados a las ELM, ellas o el municipio?, ¿cómo se compagina el horario para prestar esos servicios en las ELM sin superar el número de horas que se deben hacer reglamentariamente? Etc...

Conforme recogíamos en el apartado anterior, en el art. 8 del Real Decreto 1732/1994, el desempeño de las funciones de Secretaría en las EATIM que gocen de personalidad jurídica se efectuará en los términos que establezca la normativa específica que les sea de aplicación. En su defecto, corresponderá al Secretario del municipio a que pertenezca, a funcionario de la Corporación o a cualquier otra persona con capacitación suficiente, por el orden indicado. En este supuesto se estaría hablando de una posible delegación de funciones del Secretario a un funcionario carente de habilitación nacional. Resulta ilustrativo un problema de delegación de las funciones de FHE ocasionado en un Distrito del municipio de Barcelona, resuelto por la STS 28 de septiembre de 1994 y 04 de diciembre de 1990 en las que se impugnaban preceptos del Real Decreto 1174/1987 en relación a las previsiones del mismo en cuanto a la delegación de funciones de Secretaría e Intervención ${ }^{235}$.

\footnotetext{
${ }^{235}$ De la fundamentación de ambas sentencias SANCHEZ MARIN, R. C. (Cfr. "Delegación de la función de secretaría en funcionarios carentes de habilitación nacional”, Diario La Ley, 1992, pág. 582, Tomo 3) recoge los siguientes argumentos a favor de la legalidad de la delegación: (Si bien en el supuesto relatado no se deseaba por el cuerpo de FHE que obre la delegación en virtud del criterio de reserva de funciones; en el caso de la posible delegación de las funciones de secretaría en las ELM sería distinto y no equiparable y si cabría tal delegación ante la regulación que hace el art. 8 del Real Decreto 1732/1994):

- La alternativa a esta medida, la creación de otro puesto de trabajo con función de Secretaría y atribuidos a funcionarios con habilitación nacional, no es una obligación para el Ayuntamiento, sino sólo una facultad.

- Es perfectamente aceptable la delegación porque es una técnica de organización que no altera el régimen de responsabilidad administrativa que por imperativo legal está reservado para la función de Secretaría en todo caso. El art. 92.3 LBRL sólo establece la reserva de la responsabilidad administrativa por estas funciones, pero no reserva su ejercicio efectivo en todo caso a los funcionarios con habilitación nacional.

- La delegación la hace la Corporación como titular del órgano externo en que se engloba la actuación de esos funcionarios con habilitación nacional y lo hace en uso de las potestades autoorganizatorias que le confiere el art. 4 LBRL; en este sentido se puede considerar competente en tanto ostenta la titularidad orgánica del sector en que se desarrollan las funciones discutidas y es el centro de imputación de los efectos externos de los actos de dichos funcionarios.
} 
Estas dos alternativas a la llevanza del puesto por el propio secretario municipal, no siempre han estado claras ${ }^{236}$, ya que, ¿podría el Ayuntamiento o la propia Junta Vecinal nombrar a otra persona?, ¿qué debería entenderse por persona capacitada a los efectos del art. 8 del Real Decreto 1732/1994?. Como dice el Procurador del Común de Castilla y León en su informe de 12 de julio de 2010, y se infiere de la normativa expuesta, "la responsabilidad administrativa de las funciones públicas inherentes a la Secretaría está reservada a funcionarios en posesión de la habilitación de carácter estatal”, así se establecía ya en el artículo 92 LRBRL. A este respecto ha sido muy importante la Sentencia del Tribunal Superior de Justicia de Castilla y León de 17 de noviembre de 200, la cual señaló con relación a la interpretación del citado artículo 8 y el concepto de "persona con capacidad suficiente" que: "Aún cuando de una primera lectura pudiese colegirse que como última posibilidad puede cualquier persona actuar como secretario municipal de una entidad local menor, pues se contrapone el sustantivo "persona" frente al sustantivo "funcionario" utilizado anteriormente, ello no es sino la constatación de un orden de actuación obvio y es que a sólo a falta de funcionarios de la corporación cabría acudir al auxilio de terceras personas. Pero, al exigir que "tengan la capacitación suficiente" (y no dice la capacidad, que haría pensar en una capacidad cultural -leer y escribir, v. gr.- sino capacitación), hay que pensar, forzosamente en la posesión, por el llamado a suceder en esas funciones, de una capacitación legal, o lo que es lo mismo, de una habilitación legal. Y esta interpretación casa no solamente con la importancia de esa función a desarrollar, sino con la exigencia de la legal habilitación nacional para concursar a este tipo de puestos de trabajo”. Y concluye: “.... cabe concluir que resulta legalmente preceptiva la asistencia del Secretario del municipio a sus sesiones para realizar las funciones que le son propias. Y que en los casos excepcionales en que no sea posible su asistencia (ausencia, enfermedad etc...), deberá desempeñar accidentalmente sus funciones un funcionario del municipio en que se integre esa Junta Vecinal que ostente la titulación necesaria. Y sobre su defecto cabrá acudir al auxilio de la Diputación Provincial. Queda vedada la posibilidad de desempeñar esta función a

[...] ...dice SANCHEZ MARIN que los Tribunales no han tenido reparos en admitir la posibilidad de delegar el ejercicio efectivo de las funciones reservadas en relación a entidades locales menores, como vía de flexibilidad en este sistema tan rígido.

${ }^{236}$ STSJ 6 de mayo de 2011: “....pero no contempla [la normativa autonómica] la prestación de dichas funciones por otras personas con capacitación, aunque no ignoramos que esta tercera vía es muy utilizada en municipios y EELLMM de Castilla y León, dado el elevado número de municipios y entidades locales menores que existen en este territorio autonómico que obliga a agotar todas las vías para garantizar que se presten tales funciones de secretaria". 
cualquier vecino, sin que suponga hallarse habilitado el hecho de que ese vecino se integre en la Junta Vecinal”. Así las cosas el TSJ es claro al establecer que no se puede desempeñar dichas funciones por cualquier persona si bien y así ha sido alegado por la Junta de Castilla y León, dicha sentencia se produjo en un momento temporal en el que estaba vigente la Disposición Adicional $6^{\mathrm{a}}$.

Como principales problemas "técnicos", sin analizar en estos momentos los propios de gestión, los secretarios locales se encuentran con la dificultad de simultanear y compaginar sus obligaciones como secretarios municipales y de las entidades locales menores $^{237}$, y ante esto quiero remarcar que el TSJ en la ya citada sentencia de 6 de mayo de 2011 señaló, que: "para llevar a cabo el desempeño de sendas secretarias en ningún caso puede obligarse al secretario a que lleve a cabo una jornada laboral superior a la legal o a la contratada, pero nada impide que el Ayuntamiento y la citada ELM puedan a este respecto colaborar y llegar a un acuerdo mediante la correspondiente gestión de carácter político para que parte de la jornada laboral pueda ser repartida entre una y otra Secretaría, o para que se busquen formulas que a la vista del trabajo del Secretario existente en ambas secretarías se premien los servicios que preste a la ELM o través de compensaciones en la jornada laboral o aumento de las retribuciones complementarias en virtud de servicios extraordinarios, especial dedicación etc. En definitiva supone volver a exigir a los responsables municipales responsabilidad política para garantizar un acuerdo de gestión que facilite una ejecución lógica, proporcional y razonable de los pronunciamientos de esta sentencia. Que por otro lado, nada impide que para la prestación de mencionadas funciones por el citado Secretario pueda auxiliarse en una u otra secretaría de personal administrativo que se contrate al efecto (en el caso de no

\footnotetext{
237 El Consejo de Colegios profesionales de Secretarios, Interventores y Tesoreros de Castilla y León adoptó un posicionamiento el 27 de abril de 2012 ante esta problemática, señalando la falta de apoyo y de regulación de la situación, la ausencia de desarrollo normativo de la legislación autonómica y exigiendo entre otras peticiones la clasificación como independientes de aquellos puestos de Secretaria-Intervención de las Entidades Locales Menores que por población o presupuesto puedan mantener dichos puestos, así como, inversamente, la exención de la obligación de mantener los mismos respecto de aquellas Entidades Locales Menores que [...] cuenten con población inferior a 500 habitantes y presupuesto inferior a 120.202,42 euros o acrediten un volumen de servicios o recursos insuficiente para el mantenimiento de dichos puestos. Pero sobre todo lo que se ha venido exigiendo con rotundidad por este colectivo fue el desarrollo reglamentario de la Disposición Adicional Sexta de la Ley 1/1998 de Régimen Local de la Comunidad, y que la comunidad autónoma fuera arbitrando mientras tanto, fórmulas flexibles para el desempeño de la Secretaría de las Entidades Locales Menores.
} 
estar contratado) y que pueda llevar a efecto esas materias administrativas que no son de competencia exclusiva del secretario [...]".

\section{3.- OTRAS REGULACIONES ALTERNATIVAS Y SUPUESTOS EN OTRAS COMUNIDADES AUTÓNOMAS}

Basándome en la regulación prevista en la normativa estatal y en concreto en el Real Decreto 1732/1994, en este capítulo no solo quiero poner de manifiesto el problema actual de la imprecisión sobre la persona llamada a desempeñar el puesto de secretaría, si no que quiero aportar algunas soluciones que, basándonos en la legislación vigente, así como alternativas reguladas en otras comunidades autónomas al respecto, pueden ser ilustrativas para que nuestra comunidad tome una decisión al respecto:

1.- Una posible solución al problema es la creación y clasificación de puestos de colaboración de funcionarios de administración local con habilitación de carácter estatal en los propios municipios:

Posibilitar, a instancia de la Entidad Local pertinente, en este caso el municipio al que pertenezcan las ELM, la clasificación y creación por parte del órgano competente de la Comunidad Autónoma respectiva de puestos de secretario/interventor (puestos en colaboración con el puesto principal del municipio) en aquellos municipios con numerosas entidades locales menores y que así se demanden. Dichos puestos de colaboración tendrán asignadas entre otras, las funciones de desempeño de las secretarías de las entidades locales menores de su municipio. A tal fin se debería desarrollar el procedimiento correspondiente, oídos el municipio, las entidades locales menores y la Diputación Provincial, en virtud de lo previsto en el art. 8.2 del Real Decreto 1732/1994, de 29 de julio, de provisión de puestos de trabajo de los funcionarios de administración local con habilitación de carácter estatal, normativa de carácter básico y plenamente vigente.

2.- Otra solución que puede complementar a la anterior y no es por lo tanto excluyente, sería la creación de agrupaciones y clasificación de puestos de FHE para el sostenimiento común del puesto de secretario en las entidades locales menores: 
Continuando con la previsión recogida en el citado artículo 8.2 del Real Decreto 1732/1994, y atendiendo a la capacidad económica de las entidades afectadas, esta opción de creación de agrupaciones de entidades locales menores para el sostenimiento en común del puesto de secretario/interventor, de manera independiente al puesto clasificado en el municipio al que pertenecen, tiene ejemplos similares en otras comunidades autónomas, pudiendo citar el Decreto 53/2010, de 5 de marzo de la Junta de Extremadura por el que se regula el procedimiento para la constitución, modificación y disolución de Agrupaciones de Entidades Locales para sostenimiento en común de puestos de Secretaría e Intervención, donde se recoge como novedad la posibilidad de Agrupaciones entre entidades locales menores para crear puestos de Secretaria/Intervención; asimismo el art. 118.5 de la Ley 5/2010, de 11 de junio de Autonomía Local de Andalucía, permite la misma opción. Como normativa autonómica en la materia también destaca el Decreto 49/2009, de 26 de febrero, sobre el ejercicio de las competencias de la Comunidad Autónoma de Galicia respecto de los/las funcionarios/as con habilitación de carácter estatal, cuyo art. 6 señala que: "el desempeño de funciones reservadas al personal funcionario con habilitación de carácter estatal en una EATIM que goce de personalidad jurídica propia, se efectuará en los términos que establezca el decreto de constitución de la misma aprobado por el Consello de la Xunta de Galicia y demás normativa en materia de régimen local aplicable, con arreglo a las siguientes opciones:

a) Mediante la creación de los puestos de trabajo reservados que fuesen necesarios, en todo caso si el presupuesto de la entidad es igual o superior a 1.000.000 de euros o, de ser inferior, si asi lo solicita la entidad.

b) Por funcionarios/as con habilitación de carácter estatal que las ejerzan en el municipio a que pertenezca la entidad local.

c) Por personal funcionario del municipio a que pertenezca la entidad local o por funcionarios/as de la propia entidad local con capacitación y titulación suficiente.

d) Por los servicios provinciales de asistencia municipal." 
En idéntico sentido el Decreto 58/2012, de 27 de abril por el que se regula el régimen jurídico de los FHE en la Comunidad Autónoma de Murcia $^{238}$. Y como otros ejemplos de regulación autonómica que aborda este tema, señalo el Decreto 195/2008, de 7 de octubre de Cataluña por el que se regulan determinados aspectos del régimen jurídico de los $\mathrm{FHN}^{239}$ o la Ley 10/2010, de 9 de julio de Ordenación y Gestión de la Función Pública Valenciana, que en su disposición adicional séptima afina sobre la determinación de régimen jurídico de los FHN.

El gobierno autonómico ha sido reacio a permitir esta opción como vía de solución a este problema, al no consentir la Junta de Castilla y León la posibilidad de clasificar nuevos puestos de secretaría calificados a su vez como agrupaciones de ELM independientes de los municipios, y no deja de ser llamativo que en otras CCAA así se haya recogido, y no solo esa opción, sino una mayor regulación de este tema, CCAA por otra parte con un número bastante más reducido de ELM en comparativa con las existentes en ésta a la que nos referimos, y que la misma siga sin dar un paso adelante para abordar esta disfunción tan demandada de solución y además tan exigida, no sólo por las propias entidades afectadas, si no por organismos de tanto peso como el TSJ de la comunidad o el Procurador del Común.

3.- Por otra parte la opción de delegación, por parte del FHE como hemos visto, de las funciones de desempeño de la secretaría de las entidades locales menores, en funcionario del municipio:

Esta opción viene prevista en el artículo 8.1 del Real Decreto 1732/1994, y se ha dicho al respecto de la misma por parte de la jurisprudencia, que esta vía de desempeño entra a funcionar en defecto de "normativa específica", tal y como afirma el citado artículo, y

\footnotetext{
${ }^{238}$ Artículo 6. Puestos en entidades de ámbito territorial inferior al municipio con personalidad jurídica. El desempeño de funciones reservadas al personal funcionario con habilitación de carácter estatal en una EATIM que goce de personalidad jurídica propia se efectuará en los términos que establezca el Decreto de constitución de la misma aprobado por el Consejo de Gobierno de la Región de Murcia y demás normativa en materia de Régimen Local aplicable, con arreglo a las siguientes opciones y por el orden indicado:

a) Mediante la creación de los puestos de trabajo reservados a personal con habilitación de carácter estatal que fuesen necesarios, en todo caso si el presupuesto de la entidad es igual o superior a 1.000.000 de euros o, de ser inferior, si así lo solicita la entidad.

b) Por personal funcionario con habilitación de carácter estatal que las ejerzan en el municipio a que pertenezca la Entidad Local.

c) Por personal funcionario del municipio a que pertenezca la Entidad Local o por personal funcionario de la propia Entidad Local con capacitación y titulación suficiente.

d) Por los servicios autonómicos de asistencia municipal.
}

${ }^{239}$ Vid. DOMINGO ZABALLOS, M.L. "Notas de actualización sobre el régimen jurídico de los FHE". Revista CUNAL $n^{\circ} 155 / 2013$, pp. 22 y ss. 
consiste en la posibilidad de que aquellos municipios con personal funcionario con titulación suficiente se le/s pudieran delegar por parte del secretario/secretariointerventor/interventor las funciones de desempeño de los puestos de secretaría/intervención (de esta vía de solución encontramos un ejemplo en la Ley 6/1994, de 19 de mayo reguladora de las entidades locales menores en Cantabria, en su art. 37.1).

\section{4.- EL EFÍMERO DECRETO 33/2013, DE 18 DE JULIO POR EL QUE SE ESTABLECEN LOS TÉRMINOS PARA EL DESEMPEÑO DE LAS FUNCIONES PÚBLICAS NECESARIAS Y RESERVADAS A LOS FUNCIONARIOS CON HABILITACIÓN DE CARÁCTER ESTATAL EN LAS ENTIDADES LOCALES MENORES DE CASTILLA Y LEÓN}

Partiendo de la exigencia legal derivada de la Disposición Adicional 2a del EBEP donde se determina la necesidad de que todas las entidades locales sin excepción, estando entre ellas las ELM, cumplan con las funciones públicas necesarias y reservadas, como garantía de su correcto, legal y uniforme funcionamiento, donde se ancla el fundamento principal a esta nueva norma.

Para dar una respuesta a la situación existente en Castilla y León donde, como hemos visto, hay un gran número de ELM, y que dicha realidad dificulta la prestación de las funciones necesarias y reservadas a los funcionarios de administración local con habilitación de carácter estatal por parte del órgano al que le corresponden, así como, que en el momento presente se han intensificado las necesidades y exigencias derivadas del control de la gestión económico financiera de las Administraciones Públicas en general, y de la Administración Local en particular, como consecuencia del principio constitucional de estabilidad presupuestaria, el Decreto 33/2013, de 18 de julio, concreta las reglas para el ejercicio de dichas funciones, pormenorizando, en su caso, los criterios para el reparto del desempeño de las mismas entre los citados órganos.

En la Exposición de Motivos del citado Decreto, se recoge la clave de bóveda de la norma (la finalidad de desarrollar reglamentariamente la Disposición Adicional $6^{a}$ de la Ley 1/1998): pormenorizar los criterios para el reparto del desempeño de las funciones necesarias y reservadas, diferenciando "aquellas más cercanas y que requieren una 
intervención directa, que se encomiendan al funcionario habilitado, de aquellas que por su naturaleza pueden ser atendidas de forma distante, que se encomiendan a la colaboración de los órganos de las Diputaciones Provinciales y del Consejo Comarcal del Bierzo [...]".

A efectos de proceder a la regulación de la llevanza de dichas funciones, y haciendo una distinción entre los tres diferentes supuestos que por clase en función de la población existente en el municipio, nos podemos encontrar, se propone un sistema de tres opciones o formas de desempeño dirigido a los municipios donde la secretaría y la intervención se desempeñan de forma conjunta (dejando para el resto de municipios, -los de más de 5.000, y los de más de 20.000 habitantes-, la posibilidad de colaborar por parte de la Diputación Provincial mediante convenio interadministrativo):

- desempeño por los funcionarios de administración local con habilitación de carácter estatal que las tienen atribuidas en el municipio o municipios agrupados.

- la firma de un convenio entre las entidades locales implicadas.

- distribución de funciones entre los órganos con competencias en esta materia.

1.- Sistema mediante el ejercicio por los funcionarios de administración local con habilitación de carácter estatal que las tienen atribuidas en el municipio/s agrupados.

Se recoge aquí la opción de que los funcionarios habilitados del municipio/s puedan mantener el desempeño en todas las entidades locales menores pertenecientes al municipio, ejerciendo por tanto las funciones propias de su subescala y categoría. De ese modo el secretario desempeñará las funciones reservadas (el Decreto las enumera en: secretaría, control y fiscalización interna de la gestión económico y presupuestaria, contabilidad, tesorería y recaudación, así como el cumplimiento de las obligaciones de información, derivadas de la Ley Orgánica 2/2012 de 27 de abril de Estabilidad Presupuestaria y Sostenibilidad Financiera ${ }^{240}$ ).

\footnotetext{
${ }^{240}$ Se observa la importancia (recordemos el efecto que estaba teniendo la regulación prevista en el anteproyecto de la Ley de racionalización y sostenibilidad de la administración local), que se da a la regulación derivada de la LO $2 / 2012$, de 27 de abril de estabilidad presupuestaria y sostenibilidad financiera, y la Orden HAP 2105/2012, de 1 de octubre, que desarrolla la información a suministrar en cumplimiento de la anterior ley, cuestión no baladí, ya que estamos hablando de la remisión de información y datos extensos, con una frecuencia en algunos casos trimestral, y que en la mayoría de los municipios únicamente cuentan con un funcionario que es el Secretario-Interventor.
} 
Además se prevé que el desempeño de estas funciones reservadas sea retribuido por el municipio o municipios agrupados mediante complemento de productividad, financiado por las entidades locales menores beneficiarias, previo convenio suscrito con las mismas al objeto de financiar dicho concepto retributivo ${ }^{241}$, poniendo así final a las dudas existentes en cuanto a quién debía retribuir a los FHE por esas funciones y si efectivamente debían ser retribuidas.

Este sistema tiene una segunda parte que nos enlaza con la segunda opción, que es que en aquellos municipios donde existan más de tres entidades locales menores, o el presupuesto/s municipal/es conjuntamente con los de las entidades locales menores superen la cuantía de 500.000 euros, por exceso de carga de trabajo podrá el FHE solicitar la asistencia técnica y jurídica a la Diputación Provincial. Dicha solicitud se deberá presentar en el plazo de un mes desde su toma de posesión (y según la Disposición Final $1^{\mathrm{a}}$ desde la fecha de entrada en vigor de la norma, que prevé una "vacatio legis" de 20 días) dirigido al Alcalde para que éste promueva la formalización de un convenio con la institución provincial, pasando de este modo al siguiente sistema de llevanza.

\section{2.- Convenio interadministrativo local.}

Solución también planteada con carácter voluntario previendo la posibilidad de negociar que el desempeño de dichas funciones reservadas se ejerciten en los términos que se pacten en dicho documento, cuyas elementos subjetivos serán la Diputación Provincial por un lado y cada Ayuntamiento y sus ELM afectadas por otro, es decir, un Convenio a tres partes, pero, previa audiencia por escrito por quien ocupe el puesto de FHE. Se prevé un plazo de tres meses para la firma de los posibles convenios y se regula no solo la financiación del coste del complemento de productividad que vimos en el sistema anterior, sino además la obligación de pago de las correspondientes tasas administrativas que hayan podido fijar las Diputaciones Provinciales o el Consejo Comarcal del Bierzo por los servicios que vayan a prestarse en este ámbito.

\footnotetext{
${ }^{241}$ Para proceder a la financiación del complemento retributivo correspondiente se ponderará, entre otras, su número, presupuesto y población, así como el volumen de recaudación municipal por tributos a cargo de los residentes en cada entidad local menor.
} 


\section{3.- Distribución de funciones entre los órganos con competencias en esta materia.}

Esta opción se prevé como solución de cierre o residual, al establecer el Decreto que: "a falta de convenio al que se refieren los artículos anteriores, las funciones públicas y reservadas en las ELM de un municipio o agrupación de municipios, se desempeñarán por arreglo a las siguientes reglas". Las cuales son:

- Corresponderá a quien ocupe el puesto con habilitación de carácter estatal de cada municipio o agrupación de municipios, el desempeño en todas las ELM dependientes de estos, de las funciones de fe pública y el asesoramiento legal preceptivo [...] así como las de control y fiscalización interna de la gestión económico-financiera y presupuestaria.

- Corresponderá al Servicio de Asistencia a Municipios de las Diputaciones Provinciales (y del Consejo Comarcal del Bierzo), el desempeño ${ }^{242}$ en todas las ELM de la provincia, de las funciones de contabilidad ${ }^{243}$ y recaudación ${ }^{244}$, así como las de asesoramiento legal preceptivo de gestión del patrimonio, con excepción respecto a estas últimas de las atribuidas al FHE del municipio/os agrupados referidas a la calificación jurídica de los bienes. Y también les corresponderá el desempeño en todas las ELM de la provincia del cumplimiento de las obligaciones de información, derivadas de la LO 2/2012, de 27 de abril de Estabilidad Presupuestaria y Sostenibilidad Financiera.

Respecto de estos servicios, se prevé de nuevo que las Diputaciones puedan acordar el pago de las tasas administrativas correspondientes, en su caso.

\footnotetext{
${ }^{242}$ Este desempeño a través de las oficinas de los SAM/SAT exige previa conformidad expresa manifestada por escrito por el Alcalde pedáneo de cada entidad local menor.

${ }^{243}$ La Disposición Adicional Segunda apdo. 2 establece que sin perjuicio de lo previsto en el decreto, cualquier entidad local menor durante la tramitación del concreto expediente de elaboración de sus presupuestos, podrá solicitar el asesoramiento jurídico, dirigiéndose, a su elección, al funcionario con habilitación de carácter estatal que desempeñe.

${ }^{244}$ Esta regulación bien merece una crítica, puesto que los servicios provinciales de recaudación no se desempeñan, normalmente, por los Servicios de Asistencia a Municipios.
} 
Por último el Decreto recoge unas Disposiciones Adicionales donde se prevé la posibilidad de colaboración de otro personal de las respectivas entidades locales con los FHE para efectuar:"propuestas de actas, de informes, de diligencias, de resolución y, en general, de cualquier acto administrativo que sean precisos"; así como la asistencia técnico o material en términos del Real Decreto Legislativo 3/2011 por el que se aprueba el Texto Refundido de la Ley de Contratos del Sector Público. Ante esta regulación novedosa que se operaba en Castilla y León y después de 15 años de espera para disponer de dicho desarrollo reglamentario estaba claro que la iniciativa correspondía a las Diputaciones Provinciales para encarar el problema y la situación.

Estando así las cosas la Diputación de Palencia, a través del Servicio de Asistencia a Municipios (SAM), elaboró y aprobó en agosto del año 2013 el primer Reglamento de funcionamiento de un nuevo servicio de desempeño completo de las funciones reservadas en las entidades locales menores. Dicho texto fue acompañado de una Ordenanza fiscal reguladora de la Tasa por dicho servicio. En ese Reglamento se regularon dos tipos de asistencia:

a) Asistencia dirigida a garantizar/realizar el desempeño de las funciones propias de la Secretaria reservadas a los funcionarios con habilitación estatal.

b) Las funciones de contabilidad y asesoramiento legal preceptivo de gestión del patrimonio, con excepción respecto a estas últimas de las atribuidas al funcionario con habilitación de carácter estatal del municipio o municipios agrupados referidas a la calificación de los bienes, conforme lo dispuesto en los artículos 5.3 y 6 del Real Decreto 1174/19987, de 18 de septiembre y el desempeño del cumplimiento de las entidades locales menores de las obligaciones de información, derivadas de la Ley Orgánica 2/2012, de 27 de abril, de Estabilidad Presupuestaria y Sostenibilidad Financiera.

Para poder llegar a esta conclusión, fueron analizados los presupuestos aprobados por las ELM en el año 2013 y se estableció como presupuesto medio de las mismas el importe de 20.000 euros anuales, entendiendo que los gastos de personal no deberían superar aproximadamente el $20 \%$ del importe total de los presupuestos, la Ordenanza Fiscal aprobada no superaba, escasamente llegaba a cubrir el $75 \%$ del servicio que se estaba poniendo en marcha. 
Por parte de otras Diputaciones también se fueron adoptando algunas soluciones, así cabe destacar que la Diputación de Soria en el mes de septiembre de 2013, elaboró un modelo de Convenio Tipo de colaboración entre los ayuntamientos y sus juntas vecinales para el desempeño de las funciones públicas necesarias para facilitar el desarrollo de lo previsto en el art. 4 del Decreto 33/2013.

Pero con lo que no se contaba es que en el mes de septiembre, a los dos meses escasos de aprobación de este Decreto, la comunidad autónoma procedía a derogarlo a través de la Disposición Derogatoria única de la Ley 7/2013, de Ordenación, Servicios y Gobierno del Territorio de Castilla y León, ya que dicho texto legal deroga la Disposición Adicional $6^{a}$ de la Ley 1/1998, de 4 de junio de régimen local de Castilla y León, y el desarrollo reglamentario de la misma, y por ende el Decreto 33/2013. Así que no podíamos más que afirmar que dicho Decreto había nacido muerto.

Nos encontramos por tanto en la situación de partida otra vez, al haber desaparecido de la regulación autonómica sobre régimen local cualquier mención al desempeño de las funciones de secretaría en las ELM, debiendo volver a la regulación anterior, que es la formada por el art. 8 del Real Decreto 1732/1994, pues ¿parece? que la intención de la Comunidad Autónoma era flexibilizar y recuperar la figura de la "persona con capacidad suficiente", concepto jurídicamente indeterminado, con los problemas de interpretación y la inseguridad jurídica que ello acarrea, pues, ¿se admitirán unas cuentas fiscalizadas e informadas por una persona con “capacidad suficiente”?. ¿Podrá ejercitar esa personal una función tan delicada como puede ser la fe pública ${ }^{245}$ ?

Ante esta nueva situación la Diputación de León en el mes de octubre aprueba el establecimiento de una Tasa por la prestación del servicio de las funciones de contabilidad y gestión presupuestaria a las ELM de la provincia de León (excluyendo a los municipios pertenecientes a la Comarca del Bierzo y a los municipios de más de 20.000 habitantes). Ninguna otra función. Por su parte la Diputación de Burgos en el mes de noviembre de 2013 aprueba, a través del Servicio de Asistencia (SAJUMA) un Reglamento de la función de asistencia a las ELM de la provincia de Burgos en materia

\footnotetext{
${ }^{245}$ Es muy interesante traer al respecto el dictamen del Consejo Consultivo de Extremadura de 19 de mayo de 2005 en el que una ELM desea nombrar, siguiendo lo previsto en el art. 8 RD 1732/1994, a persona con capacidad suficiente y para ello convoca un procedimiento de interinidad. La resolución del alcalde pedáneo designando a dicha persona es impugnada mediante procedimiento de nulidad por haber prescindido del procedimiento para la designación de la interinidad, cuya resolución le correspondería a la CA y no al Alcalde pedáneo. Situación muy peligrosa y ciertamente desconcertante.
} 
de la gestión económico-financiera. Como funciones de asistencia regula, de una manera muy similar a como lo hizo Palencia en su Reglamento inicial, las siguientes:

- De contabilidad: elaboración de presupuestos, mecanización de contabilidad, confección de liquidación y de la Cuenta General y remisión telemática de los presupuestos, liquidación y cuenta general.

- Las funciones de remisión de información contable derivadas de la Ley Orgánica 2/2012 de estabilidad presupuestaria.

Asimismo Burgos aprueba una Ordenanza reguladora de precio público por la asistencia contable ofrecida, estableciendo los importes en función de tramos de población $^{246}$, pero tampoco se aborda ninguna otra función a mayores. La Diputación de Salamanca por su parte elabora un modelo de convenio tipo ${ }^{247}$ para proceder a regular,

\footnotetext{
${ }^{246}$ Hasta 100 habitantes: 300 euros. De 101 a 300 habitantes: 500 euros. Superior a 301: 800 euros. Las que estén sometidas a la Instrucción Contable simplificada abonarán el doble de los precios establecidos.

247 Como antecedente, ya visto en el Capítulo III, merece destacar el Convenio realizado por el Ayuntamiento de Tordesillas con sus ELM en diciembre del año 2011 para el ejercicio de determinadas competencias y su financiación: En los servicios prestados por delegación se incluyen los costes siguientes: - Costes fijos: Aquellos que se producen independientemente de la cantidad de agua suministrada o tratada para una determinada capacidad máxima (v. gr., gastos de personal, energía eléctrica (término de potencia), gastos de vehículos, compra de agua (componentes fijos), gastos de conservación y mantenimiento, amortización, facturación y otros.

- Costes variables: Aquellos que varían en función de la cantidad de agua suministrada o tratada para una determinada capacidad máxima (v. gr., energía eléctrica (término de energía) compra de agua (componentes variables), tratamiento).

- Costes de expansión del servicio: Aquellos en los que se incurre para alterar la capacidad máxima de suministro o saneamiento existente en un momento determinado.

Por el ejercicio de las competencias propias y el conjunto de servicios municipales mencionados en el apartado 1 A y C) de esta cláusula que la Entidades Locales Menores prestan, teniendo en cuenta el nivel de prestación de dichos servicios en relación con la media existente en el resto del término municipal, la población, el esfuerzo fiscal en su conjunto y la disponibilidad respectiva del municipio y de las entidades locales menores, el Ayuntamiento de Tordesillas aportará anualmente a las aludidas entidades los siguientes importes netos:
}

Entidad Local Menor de Villamarciel. . . . . . . . . . . 95.000,00 euros.

Entidad Local Menor de Villavieja del Cerro. . . . . . . . . 55.000,00 euros.

Por otro lado y en base a la situación económica de ambas Entidades Locales

Menores, el Ayuntamiento de Tordesillas aportará los siguientes importes netos a cada una de ellas para satisfacer el pago de las obligaciones pendientes de pago de ejercicios anteriores. De este modo, las Entidades Locales Menores estarán obligadas a comunicar trimestralmente los pagos que se han efectuado con cargo a estas cantidades. Si por el contrario, las cuantías establecidas a continuación no se destinarán a satisfacer las obligaciones pendientes de pago de ejercicios anteriores, el Ayuntamiento de Tordesillas detraerá de la cantidad ordinaria el importe que se hubiese destinado a satisfacer finalidades distintas de las determinadas para estas cuantías extraordinarias.

Dichos importes serán de:

Entidad Local Menor de Villamarciel. . . . . . . . . . . . 10.000,00 euros.

Entidad Local Menor de Villavieja del Cerro. . . . . . . . . . . 5.000,00 euros.

En los citados importes se consideran incluidos las aportaciones municipales a las obras que anualmente incluye la Diputación Provincial de Valladolid en el apartado especial de los Planes Provinciales de Cooperación Municipal, destinado a las Entidades Locales Menores. 
una vez aprobada la Ley 7/2013, las relaciones, y compensaciones económicas ${ }^{248}$, así como las posibles delegaciones de obras y servicios entre los municipios y sus ELM, estableciendo en la cláusula II apdo. 5 la regulación de la relación con el secretario municipal, muy similar a la que venía recogida en el derogado Decreto 33/2013.

La Diputación de Palencia, ante esta nueva situación, decidió adaptar el reglamento aprobado en verano a la nueva regulación normativa, y en el mes de diciembre del año 2013 se aprobó la adaptación del Reglamento y la Ordenanza físcal, previendo ahora un único supuesto de asistencia contable y presupuestaria, consistente en la realización de la mecanización contable, la asistencia en la elaboración del proyecto/expediente del presupuesto anual, modificaciones presupuestarias y demás documentos objeto de la gestión presupuestaria, la asistencia en la elaboración de la liquidación anual del presupuesto, la remisión telemática de la Cuenta General de las Juntas Vecinales al Consejo de Cuentas, junto con la asistencia para la confección del expediente administrativo correspondiente, y la función de asistencia en el cumplimiento de las obligaciones de información derivadas de la Ley Orgánica 2/2012, de estabilidad presupuestaria. Es decir, se circunscriben las funciones a desempeñar por parte de la Diputación, de mera encomienda de gestión técnica en el área de la gestión contable y presupuestaria, no se extiende a ninguna otra función, al haber quedado la intervención de las Diputaciones Provinciales fuera del campo de actuación de las mismas.

\footnotetext{
Los servicios municipales prestados por delegación por las Entidades Locales Menores incluidos en el apartado 1. B de esta cláusula, deben ser financiados con precios públicos o tasas, según proceda.

${ }^{248}$ Interesante la regulación recogida en la cláusula II apdo. 4: 4.- El Ayuntamiento abonará a la Entidad Local Menor, por el conjunto de competencias y servicios que asume y para los ejercicios económicos de 201.-201., la cantidad resultante de los cargos de los padrones fiscales y participación en los tributos del Estado, correspondientes a cada ejercicio económico del que se trate, en la forma que se detalla en el siguiente Apartado. Cláusula III: 1.- La aportación económica referida en la cláusula cuarta anterior de este Convenio, se realiza con base a los cargos de los Padrones Fiscales correspondientes a la Entidad Local Menor del Impuesto Sobre Vehículos de Tracción Mecánica (IVTM), Impuesto de Actividades Económicas (IAE), e Impuesto sobre Bienes Inmuebles (IBI). A dicho importe hay que añadir la participación en los tributos del Estado, de acuerdo a la población correspondiente a la Entidad Local Menor (según datos del I.N.E: cifras de resultantes de la revisión del Padrón Municipal de Habitantes referidas a 1/01/12, aprobadas por Real Decreto 1697/2012). 2.- Corresponderán, igualmente, a la Entidad Local Menor los ingresos procedentes del Impuesto sobre Construcciones, Instalaciones y Obras (ICIO), cuyo hecho imponible se produzca en el término de... a partir del 1/01/14, y que serán librados, conforme a la cláusula referida a la forma de pago establecida en el presente Convenio.
} 


\section{5.- LA SITUACIÓN GENERADA POR LA LRSAL 27/2013}

Desde el mes de julio de 2012 se comenzó a gestar, haciéndose público en ese momento, el primer borrador de muchos del anteproyecto de ley de reforma local que recibió el nombre, y así se ha mantenido en su aprobación, de Ley de Racionalización y Sostenibilidad de la Administración Local, como respuesta a una demandada o supuestamente demandada reforma y modernización de la Administración Pública española.

Tal reforma obedece al actual contexto de crisis económica, o más bien institucional, en el que se encuentra inmerso nuestro país, y que pretende dar una respuesta a las aspiraciones de una sociedad que demanda una administración más moderna y una racionalización en el sistema competencial actual que evite duplicidades o solapamientos entre las administraciones. De este modo se comienza en esa labor de modernización con la administración local, aspecto que no deja de llamar la atención cuando es la administración que menos déficit y menos nivel de endeudamiento presenta respecto de los otros escalones territoriales ${ }^{249}$.

Uno de los puntos más polémicos incluidos en esta reforma, y que más repercusión ha tenido en Castilla y León, fue el anuncio directamente en el primer borrador de la norma de la supresión al día siguiente de la supuesta entrada en vigor de la misma, de todas y cada una de las entidades locales menores del país ${ }^{250}$. Este anuncio y previsión normativa pusieron en el disparadero a estas entidades y en el punto de mira o casi de conocimiento, respecto de las mismas hacia el resto del país. Después de diversas versiones del texto finalmente parece que se optaba por decir, en la Disposición

\footnotetext{
${ }^{249}$ La deuda del conjunto de las EELL apenas representa el 4,5\% del PIB de toda la deuda pública nacional. Las EELL cerraron 2011 con un $-0.45 \%$ de déficit y en el año 2012 con un superávit del $0.222 \%$, con un crecimiento cercano al 0.6\%. (Vid. Iñigo de la Serna. Presidente de la FEMP. Revista Democracia y Gobierno Local $n^{\circ}$ 23. Año 2013. Pp. 17).

${ }^{250}$ Las Cortes de Castilla y León en fecha de 23 de marzo de 2013, a través de los tres grupos con representación en las mismas, el popular, el mixto (en el que se encuadran IU y Unión del Pueblo Leonés) y el socialista, presentaron una proposición conjunta no de ley en defensa de las ELM, regidas por las Juntas Vecinales, concejos y pedanías, advirtiendo que en PRLSAL excluye a las EATIM del ámbito administrativo público y niega personalidad jurídica a las nuevas que puedan crearse. Las Cortes consideran en la proposición no de ley que las modificaciones que se plantean en la legislación del régimen local, tanto en la CA como en el Estado, han de garantizar la pervivencia de las ELM "con plena personalidad jurídica y con naturaleza de entidad local territorial.
} 
Transitoria Cuarta del Proyecto de la $\operatorname{Ley}^{251}$ (PLRSAL), que no se suprimirían de primeras, si no que se optaba por regular una condición y que era que si no rendían cuentas en el plazo de tres meses desde que entrara en vigor la ley, entonces se incurriría en causa de disolución de las mismas ${ }^{252}$. Finalmente se ha optado, por dar un plazo más amplio, estableciendo como fecha límite de esa rendición de cuentas el 31 de diciembre de $2014^{253}$.

${ }^{251}$ Enmienda de la FEMP a la Disposición Transitoria 4 a del PLRSAL: Justificación:

En concordancia con las propuestas realizadas a la modificación de los artículos 3 y 24 bis de la LRBRL debería suprimirse el apartado 1 de esta Disposición Transitoria.

Por otra parte, que sea el Decreto de la Comunidad Autónoma el que determine la reconversión de la EATIM suprimida en una forma de organización desconcentrada del Ayuntamiento, supone una intromisión en la potestad de auto organización de los Municipios.

Asimismo, por la naturaleza de estas Entidades, se debería ampliar el plazo para poder presentar sus cuentas por lo menos a seis meses, ya que tres meses es muy poco tiempo.

Propuesta:

Se propone la modificación de esta Disposición con la siguiente redacción:

““'Disposición transitoria cuarta. Disolución de entidades de ámbito territorial inferior al Municipio.

1. En el plazo de seis meses desde la entrada en vigor de esta Ley las Entidades de ámbito territorial inferior al municipio deberán presentar sus cuentas ante los organismos correspondientes del Estado y de la Comunidad Autónoma respectiva para no incurrir en causa de disolución.

2. La no presentación de cuentas por las Entidades de ámbito territorial inferior al municipio ante los organismos correspondientes del Estado y de la Comunidad Autónoma respectiva será causa de disolución. La disolución será acordada por Decreto del órgano de gobierno de la Comunidad Autónoma respectiva. El Ayuntamiento al que perteneciera la Entidad o Entidades disueltas podrá acordar su mantenimiento como divisiones territoriales propias, dotadas de órganos de gestión desconcentrada.

3. La disolución en todo caso conllevará:

a) Que el personal que estuviera al servicio de la Entidad disuelta quedará incorporado en el Ayuntamiento en cuyo ámbito territorial esté integrada.

b) Que el Ayuntamiento del que dependa la Entidad de ámbito territorial inferior al municipio queda subrogado en todos sus derechos y obligaciones."

${ }^{252}$ Una de las novedades de la LRSAL era que las ELM dejaban de tener condición de entidad local y personalidad jurídica, pero no solo las de nueva creación, sino también las existentes hasta el momento. Una enmienda presentada en el Senado el 16 de diciembre, casi al punto de aprobar la LRSAL, por parte del Grupo Socialista y del Grupo Progres de Catalunya solicitó y se aceptó, la modificación de la Disposición Transitoria Cuarta en su apdo. 1 para que las ELM existentes en el momento de la entrada en vigor de la presente ley no solo mantuvieran su personalidad jurídica si no también, (que no figuraba) su condición e entidad local.

${ }^{253}$ Grupo Parlamentario Popular: enmienda de modificación a la Disposición Transitoria 4 a PLRSAL: Se propone la modificación del apartado segundo de la Disposición Transitoria Cuarta con la siguiente redacción:

"Disposición transitoria cuarta. Disolución de entidades de ámbito territorial inferior al municipio.

.......

2. Con fecha de 31 de diciembre de 2014, las entidades de ámbito territorial inferior al Municipio deberán presentar sus cuentas ante los organismos correspondientes del Estado y de la Comunidad Autónoma respectiva para no incurrir en causa de disolución". Justificación: Por la naturaleza de estas Entidades, se amplía el plazo para poder presentar sus cuentas por lo menos durante un año, ya que tres meses es muy poco tiempo. 
Pero, ¿qué generó esta nueva regulación?. Lo que está claro es que hoy en día unas ELM que en muchas ocasiones manejan más recursos económicos que los propios municipios a los que pertenecen, no pueden estar sin rendir cuentas, si bien y ante la falta de medios técnicos y personales que tienen estas entidades y de falta de regulación específica (que veremos más concretamente en el siguiente capítulo) se ha consentido esta situación por las diversas administraciones con competencias para ello, y para conseguir una adecuación correcta a la normativa contable y presupuestaria aplicable en este momento, y ante el cada día más complejo panorama de la rendición de cuentas (plataformas telemáticas, firma digital, etc....), se necesita que al frente de todo ello esté una persona adecuada y profesionalizada, ejerciendo las labores de intervención.

$\mathrm{Y}$ eso es precisamente lo que no se ha resuelto hasta ahora y se sigue sin resolver como acabamos de ver.

Si bien parece que toda la problemática de la gestión y pervivencia de las ELM se quiere reducir a la simplista afirmación de que si se rinden las cuentas ya estaría todo solucionado, no es así de fácil. La ejecución presupuestaria conlleva las funciones de control y fiscalización, confección de la contabilidad y su posterior rendición, aparte de que la misma se aposente en los actos administrativos de autorización, disposición y reconocimiento de la obligación suscritos por los órganos competentes.

Y que la vida administrativa de una ELM no se puede reducir únicamente a la gestión contable, pues ¿qué pasa con la gestión del patrimonio y los aprovechamientos, la contratación, los servicios delegados, la fe pública, el asesoramiento legal preceptivo etc.... que en teoría, y se remarca lo de "en teoría", son funciones reservadas ${ }^{254}$ ?.

Ante la situación generada por la tramitación de este proyecto de ley comenzaron a proliferar movimientos en contra de la misma, constituyéndose varias ELM en Federaciones de Entidades Locales Menores ${ }^{255}$. La Federación Española de EELLMM

\footnotetext{
${ }^{254}$ VERA TORRECILLAS, R. "Los funcionarios con habilitación estatal en el contexto de la reforma del gobierno local" El Consultor de los ayuntamientos y juzgados, $n^{\circ}$ 3. 2012. Señala el autor que determinados cambios bajo la justificación de la necesidad de introducir nuevas técnicas de gestión se pretendía reducir los controles internos que desempeñaban los FHE a través de sus funciones reservadas. Y desde mi opinión la defensa de que las funciones reservadas residan en el cuerpo de FHN debería ser una de las preocupaciones del mismo.

${ }^{255}$ Se pueden citar a la Federación Palentina de ELM, la Federación Leonesa, Federación Regional de Castilla y León.
} 
realizó asimismo un análisis jurídico del PLRSAL en julio del 2013, con un conjunto de enmiendas dirigidas a preservar la entidad de estas instituciones locales ${ }^{256}$.

\section{6.- CONSIDERACIONES}

Llegados a este punto no parece que la situación ante esta problemática que se viene arrastrando desde hace años, sea nada esperanzadora, puesto que la $\operatorname{LRSAL}^{257}$ no ha procedido a dar más luz ni a perfilar el tema del régimen de las funciones de secretaría en las ELM y habrá que ver si el Estado, a través del Ministerio y del desarrollo reglamentario que debe hacer ahora del régimen jurídico del cuerpo de habilitados nacionales $^{258}$, afronta de una manera más clara e indubitada la situación y regulación del desempeño de las funciones de secretaría e intervención en las entidades locales menores.

La situación ideal pasaría desde mi punto de vista:

\footnotetext{
${ }^{256}$ El nombramiento de Secretario-Interventor de la ELA (entidad local autónoma, nombre que propone la federación española de ELM que se adopte respecto de las mismas), si ésta puede mantenerlos, se llevará a cabo como en el caso de los Municipios. Pero si ello no fuera posible:

a) Podrá recaer en persona idónea o funcionario propuesto por la ELA, previa aprobación del habilitado nacional titular en el Ayuntamiento del Municipio a que pertenezcan.

b) El ayuntamiento del Municipio al que pertenezca la ELA, podrá proponer al órgano competente del gobierno de la Comunidad Autónoma sobre Régimen Local la creación en su plantilla de plaza o plazas de personal funcionario de administración local con habilitación de carácter estatal. Incluso solicitándose la agrupación con otras Entidades para el sostenimiento común de dichas plazas.

c) En otro caso, las funciones de secretaria e intervención corresponderán al titular o titulares del Ayuntamiento respectivo.

No obstante la tesorería podrá ser conferida a un miembro de la Junta Vecinal o a un funcionario de la propia Entidad.

Entre otras funciones, el Secretario Municipal tiene la obligación de asistir a las sesiones de la Junta Vecinal de dichas Entidades, dando lugar su incumplimiento a las sanciones correspondientes de conformidad con la Ley 7/2007, de 12 de Abril del Estatuto Básico del empleado público.
}

${ }^{257}$ Nuevo artículo 92 bis: 1. Son funciones públicas necesarias en todas las Corporaciones locales, cuya responsabilidad administrativa está reservada a funcionarios de administración local con habilitación de carácter nacional: a) La de Secretaría, comprensiva de la fe pública y el asesoramiento legal preceptivo. b) El control y la fiscalización interna de la gestión económico-financiera y presupuestaria, y la contabilidad, tesorería y recaudación.

258 Vid. Nota interpretativa del MINHAP de 5 de marzo de 2014 a la LRSAL: señala que mientras no se produzca el desarrollo reglamentario en el tema del régimen jurídico de los FHN, mantiene su vigencia, según dispone la Disposición Transitoria $7^{\mathrm{a}}$ de la LRSAL, la regulación vigente hasta el momento, en lo que no se oponga a esta ley. 
- Por una regulación actualizada por parte del Gobierno Central, ya que en este momento se está tramitando la normativa reglamentaria de desarrollo del régimen de la habilitación nacional que no deje lagunas en este campo;

- Un desarrollo más preciso por parte de la Comunidad Autónoma donde permitan, al igual que en otras CCAA, la posibilidad de la figura de la agrupación ELM para el sostenimiento en común del puesto de secretario, clasificándolo como de puesto de nueva creación, así no solo se consiguen para el colectivo de FHN más puestos de trabajo, si no que se garantiza el desempeño de dichas funciones por personas cualificadas y preparadas con la habilitación legal necesaria;

- Prever en normativa legal como última opción, la obligatoriedad de, superando un número de ELM en una provincia, se cree una oficina nueva "ad hoc" de llevanza completa de la secretaría de estas ELM en las Diputaciones Provinciales, creando los puestos de trabajo necesarios al efecto. 


\section{PROBLEMÁTICA EN LA UTILIZACION DE LOS BIENES DE LAS ENTIDADES LOCALES MENORES}

Una de las justificaciones de la propia existencia de las ELM es la de la gestión de los bienes y/o aprovechamientos de los que son titulares. Por eso una de las batallas más frecuentes y de los problemas más asiduos en este tipo de entidades son las diversas formas del no menos diverso ámbito patrimonial que poseen. Dentro de la clasificación tradicional de los bienes, voy a exponer y analizar la problemática que estimo más habitual dentro de cada uno de ellos.

\section{1.- BIENES PATRIMONIALES}

\subsection{Régimen jurídico}

Según el art. 80.2 LRBRL, se rigen estos bienes por su legislación específica y, en su defecto, por las normas de Derecho privado. La mencionada legislación específica es la contenida en los arts. 78 a 87 TRRL, la ley 33/2003, de Patrimonio de las Administraciones Públicas (LPA) y la legislación autonómica que, en su caso exista (que en Castilla y León nada hay al respecto). Todo ello sin perjuicio de la aplicación a los bienes patrimoniales de las leyes especiales que puedan afectarles. Indico esto porque no resulta infrecuente que en la aplicación del sistema de fuentes del derecho a la gestión patrimonial haya un olvido por parte de las ELM, casi siempre por desconocimiento, de la aplicación de la LPA, la cual no debemos olvidar, contiene artículos de carácter básico que desplazan a los previstos en el RBEELL.

\subsection{Utilización de los bienes patrimoniales}

A) Los bienes patrimoniales o "de propios", contrapuestos a los denominados de dominio público (artículo 79.2 LRBRL), se definen en el artículo 76 TRRL y se rigen por normas de Derecho privado, aunque de modo preferente hayan de aplicarse las 
disposiciones especiales contenidas en la legislación administrativa. En el caso de que la ELM sea propietaria de bienes inmuebles de esta clase, puede obtener rentabilidad del uso y explotación de los mismos, y por ello ceder su utilización a otras personas, en lugar de efectuarla ella misma directamente. Para ello habrá de hacerlo a través del correspondiente contrato de arrendamiento o cesión de uso, que por razón de su objeto tendrá carácter civil y no administrativo, según el actual TR LCSP. (La Ley de Contratos del Sector Publico 30/2007 y posteriormente el TRLCSP 3/2011, introducen como novedad en el régimen jurídico de los contratos patrimoniales de las EELL, que quedan excluidos del ámbito de aplicación de la misma (art. 4.1 letra p). Como recuerda el Informe de la Junta Consultiva de Aragón 4/2009 de 15 de abril, estas alteraciones normativas obedecen, fundamentalmente, a la necesidad de establecer un régimen jurídico de los bienes más dúctil y flexible que permita la adaptación del mismo a la realidad de la práctica administrativa actual. Por lo tanto se excluye del ámbito de aplicación de la LCSP a los llamados "contratos patrimoniales" 259 , a los que no habrá que confundir con los contratos privados los cuales sí están recogidos en el ámbito de aplicación de la TRLCSP en su art. 21. Sobre esta exclusión también se pronunció la JCCA en informe 25/08 de 29 de enero viniendo a decir que tal exclusión no es absoluta: primero porque la Disposición Adicional $2^{\mathrm{a}}$ del TRLCSP contempla las reglas referentes a las competencias de los órganos de contratación de las EELL referidas a los contratos patrimoniales y segundo porque, de conformidad con el art. 4.2 TRLCSP, los contratos, negocios y relaciones jurídicas excluidos se regulan por sus normas especiales, aplicándose los principios de esta Ley para resolver las dudas y lagunas que pudieran presentarse). Es muy frecuente en Castilla y León que las ELM obtengan rendimiento económico de las fincas rústicas de su propiedad ${ }^{260}$.

Pues bien, sin perjuicio de la aplicación de las normas de Derecho privado que procedan en cada caso, según el tipo de relación contractual de que se trate, para el

\footnotetext{
259 Vid. PASTOR GARCIA, JM. "La indeterminación del régimen jurídico aplicable al contrato de enajenación por venta de los bienes municipales en Castilla y León”. El Consultor de los Ayuntamientos $\mathrm{n}^{\mathrm{o}}$ 1. 2010. Pp. 70.

${ }^{260}$ También se obtiene rendimiento económico de la realización de enajenaciones de bienes patrimoniales (Vid. PASTOR GARCIA, JM op cit), si bien debe estar dirigido a la aplicación del producto de la venta a realización de inversiones, y es muy importante realizar el procedimiento de forma correcta, puesto que el criterio habitual de la Dirección General de Registros y Notariados (cfr. Resolución de 3 de enero de 2005 , 28 de marzo de 2008) es que la existencia de infracciones legales en los mismos origina la imposibilidad de inscripción de dichos bienes por los adquirentes en el Registro de la Propiedad.
} 
arrendamiento o cesión de uso de este tipo de bienes se venía aplicando lo recogido en el artículo $92 \mathrm{RB}$, el cual señala que se debe efectuar conforme a la normativa de contratación local "en cuanto a su preparación y adjudicación”. La forma de adjudicación a aplicar había de ser en concreto la de subasta, siempre que la duración de la cesión fuera superior a cinco años o el precio estipulado exceda del 5 por 100 de los recursos ordinarios del presupuesto (art. 92.1 RB). En otro caso, de no darse tales limitaciones, es indudable que la cesión podrá efectuarse mediante concurso o, en su caso, contratación directa, por el procedimiento "negociado",261. La competencia para efectuar la adjudicación del contrato corresponde al presidente de la ELM, conforme a la DA 2 $2^{\mathrm{a}}$.1 TRLCSP, o a la Asamblea o Junta Vecinal en caso de que excediere de los límites cuantitativos y temporales que establece dicha norma.

Pero aquí es donde se da uno de los problemas más habituales en los contratos de arrendamientos de bienes patrimoniales, pues la LPA regula en sus arts. 106 y 107 los contratos para la explotación de bienes patrimoniales. Conforme al apartado 1 del primero de los preceptos, que tiene carácter básico, "la explotación de los bienes o derechos patrimoniales podrá efectuarse a través de cualquier negocio jurídico típico o atípico". A los procedimientos de adjudicación se refiere el segundo de los preceptos citado. En su apartado 1 (básico) establece la regla de que los contratos se adjudicarán por concurso, salvo que por las peculiaridades del bien, la limitación de la demanda, la urgencia resultante de acontecimientos imprevisibles o la singularidad de la operación, proceda la adjudicación directa.

Han sido varios los procedimientos impugnados por la Comunidad Autónoma en su labor de control de legalidad, debido a que no se aplica por parte de las ELM el art. 107.1 LPA que dice, como acabamos de ver, que el procedimiento procedente es el concurso, y se sigue aplicando la subasta y por lo tanto se están haciendo los expedientes con un único criterio de adjudicación (el del precio) y no con varios como debe ser si se realiza mediante concurso. Lo cual lleva a declarar estos procedimientos nulos de pleno derecho, con el problema derivado de tener que volver a tramitar el expediente y perder uno o dos años agrícolas en la tardanza de la preparación del mismo.

\footnotetext{
${ }^{261}$ La STS de 20 de abril de 1998 considera conforme a Derecho, por ello, la cesión de uso efectuada de forma directa, en un caso en que el adjudicatario de una subasta anterior no había formalizado el contrato, conforme al art. $120.1 .6^{\circ}$ TRRL.
} 
Por alguna de las ELM se ha manifestado que es una dificultad mayor el regular o decidir unos criterios que no sean únicamente el del mejor precio, y ante tal tesitura he tenido la oportunidad de discutir e informar, como criterio de adjudicación a añadir a aquel, el de ser titular de una explotación agrícola sita en el término municipal y otorgándole una puntuación que nunca supere el criterio del precio. Entiendo que es una manera de beneficiar al agricultor que dispone de explotación en el municipio (que no tiene porque ser necesariamente un vecino) pero no se conculca el principio de libertad de empadronamiento como vamos a ver en el problema que expongo a continuación.

Otro problema relacionado con la utilización de los bienes patrimoniales es la práctica habitual de muchas de las ELM en aplicar o regular en los pliegos de cláusulas que regirán el contrato de arrendamiento, criterios de restricción o de limitación del acceso a la licitación, estableciendo el que la explotación de dichos bienes sea únicamente para los vecinos del pueblo. Esto no puede ser dada la naturaleza de patrimoniales, ni tampoco establecer como criterio de adjudicación el conceder mayor puntuación a los empadronados en el municipio ${ }^{262}$. En no pocas ocasiones nos encontramos con supuestos donde las ELM, sin distinguir las diferentes naturalezas de sus bienes, hacen lotes incluyendo todos ellos, tanto los de carácter patrimonial como comunal, restringiendo el aprovechamiento de los mismos (normalmente el agrícola) exclusivamente a los vecinos del pueblo, a los que incluso a veces se les exigen determinadas condiciones de arraigo y vinculación. Esto no puede suceder de ninguna manera, ya que los bienes comunales son regulados por normas típicamente administrativas, en cambio los bienes patrimoniales están sujetos a disposiciones de derecho privado y en este tipo de bienes la entidad local actúa como si fuera una persona jurídico privada. El aprovechamiento de los bienes patrimoniales no se puede restringir únicamente a los vecinos, pues de ser así se estaría conculcando el principio de igualdad. No cabría invocar en estos supuestos la aplicación de la costumbre para realizar adjudicaciones directas ni subastas (ahora concursos)

\footnotetext{
262 A tal efecto así lo recoge el Informe de la Junta Consultiva de Contratación 7/1998, al decir: “... La segunda cuestión -la de si pueden realizarse subastas de arrendamientos de fincas rústicas estableciendo en el pliego de cláusulas administrativas particulares que sólo puedan participar en las mismas los vecinos del pueblo que reúnan determinados requisitos- merece una contestación negativa y ello sin necesidad de acudir a preceptos concretos de nuestro ordenamiento jurídico, dado que el limitar la concurrencia a vecinos que reúnan determinados requisitos, que por cierto no se especifican, es contrario al principio constitucional de igualdad de los ciudadanos y a su reflejo en el principio básico de la contratación administrativa de la libre concurrencia, debiendo significarse que los únicos requisitos que pueden ser exigidos a todos los ciudadanos son los de capacidad y solvencia y ausencia de prohibiciones de contratar previstos en la legislación vigente".
} 
restringidas, supuesto diferente al que veremos al tratar los bienes comunales ${ }^{263}$. A modo de ejemplo podemos citar la sentencia del TSJ de Castilla y León 21 de julio de 2000, que anula acuerdos de una Junta Vecinal de la provincia de Burgos, ya que aprobaron unos pliegos de condiciones para el arrendamiento de fincas rústicas limitando el acceso a la subasta a personas físicas que tengan la condición de vecinos, que además no fueran deudores de la entidad. Si bien a toda regla siempre puede haber excepciones y a tal efecto señalamos la STSJ Castilla y León de 29 de septiembre de 2006 por la que se desestima la pretensión de un vecino de no haber sido tratado en condiciones de igualdad en el pueblo al exigir éste que no solo estuvieran empadronados los licitadores, si no que tuvieran casa abierta, y el demandante no la tiene porque está empadronado en casa de sus padres quienes recibieron también el reparto de una de las fincas.

Por último quiero recordar que no es legalmente posible, la cesión de bienes patrimoniales locales a título gratuito, fuera del supuesto de cesión a entidades públicas o privadas de interés público sin ánimo de lucro, prevista en el artículo 109.2 RB, cuestión que en varias ocasiones se plantean las ELM.

\section{2.- BIENES COMUNALES}

Son bienes comunales los de las ELM, cuya propiedad y aprovechamiento corresponde al común de los vecinos ${ }^{264}$ (art. 79.3 LRBRL, y regulados en los art. 75, 77 y 78 TRRL y 94 a 108 RBEL). En cuanto a su naturaleza y no siendo el objeto de este trabajo, señalar que en la doctrina han existido voces que van de considerar a estos bienes

\footnotetext{
${ }^{263}$ El Procurador del Común de Castilla y León indica en varios de sus informes emitidos por asuntos similares a los que aquí se comentan, que las entidades deberán ajustar la licitación de sus bienes patrimoniales a lo preceptuado en los art. 92 RB y 107 LPA, pero que deberán también comprobar si se ha producido o no una alteración automática de la calificación jurídica de estos bienes, y que por trascurso del tiempo realizando ese tipo de reparto y uso de los mismos se hubieran pasado a ser comunales conforme al art. 8.4RB, y por tanto debiera ajustarse a la normativa relativa a los bienes comunales.

${ }^{264}$ La STS de 21 de febrero de 2007 señala: "que [...] lo que interesa destacar es que los bienes comunales sólo podrán pertenecer a los municipios y a las entidades locales menores (es una singularidad del patrimonio de las EELL frente al resto de AAPP) y poseen dos notas que los singularizan en relación con las distintas categorías de bienes de las AAPP. De un lado que su titularidad no es exclusiva del municipio o de la entidad local que los posea, sino que la comparten con los vecinos, y de otro que el aprovechamiento de los mismo corresponde al común de los vecinos".
} 
como una subclase de los de dominio público ${ }^{265}$, y otras que los consideran un tertium genius distinto de los anteriores, si bien yo comparto la opinión primera. La Constitución ha querido proteger especialmente los bienes comunales incluyéndolos junto a los bienes de dominio público en el art. 132. Unos y otros ostentan las mismas notas: inalienabilidad, inembargabilidad e imprescriptibilidad.

El régimen de sus aprovechamientos (problemáticos, anticuados, antieconómicos, en palabras de BOCANEGRA SIERRA ${ }^{266}$ ), son los problemas más acuciantes en la actualidad, así como las dificultades de su tráfico jurídico.

\section{1.- Problema de la titularidad compartida}

Se trata de un supuesto de titularidad compartida entre la entidad a la que corresponde la administración y los vecinos a los que corresponde el aprovechamiento, los cuales ostentan un verdadero derecho real de goce (STS de 13 de marzo de 1980, 18 de mayo de 1982, 31 de diciembre de 1986, 30 de abril de 1987 y 24 de enero de 1989). No obstante, la STS de 14 de noviembre de 1995 señala que la titularidad no corresponde al Ayuntamiento sino a los vecinos ${ }^{267}$, opinión que no comparto y entiendo que dicha posición está superada y aceptada, por lo tanto no queda más que afirmar la titularidad simultánea o compartida ${ }^{268}$.

\footnotetext{
${ }^{265}$ BOCANEGRA SIERRA, R. "Bienes comunales y vecinales" Iustel. 2007. Pág. 42, no comparte que los bienes comunales sean equiparados a los de dominio público porque al quedar excluido de los mismos el público en general, que es una característica de los bienes demaniales, no se podría equiparar. Sin embargo NIETO, A. en "La nueva regulación de los bienes comunales" Revista de estudios locales y autonómicos, $n^{\circ}$ 133, 1987, pág. 9 entiende que los bienes comunales son de dominio público.

${ }^{266}$ BOCANEGRA SIERRA, R. op cit. pág. 39.

267 La STS de 14 de noviembre de 1995 considera que "la titularidad de los bienes comunales no corresponde a los Ayuntamientos como así se desprende del artículo 79.2 de la LBRL: "los bienes de las Entidades Locales son de dominio público o patrimoniales", sin incluir en la titularidad de las entidades locales los comunales, sin perjuicio de definir su naturaleza como bienes de dominio público y ser inalienables, inembargables, imprescriptibles (artículo 80.1), en cumplimiento del mandato constitucional a que se contrae el meritado artículo 132 de la Constitución".
}

${ }^{268}$ RODRIGUEZ MORO, N. "Los bienes comunales tienen como titular al respectivo municipio" Revista Estudios Vida Local n 214. Junio 1982. 
Como señala BOCANEGRA SIERRA ${ }^{269}$, lo que siempre existe en los bienes comunales es una comunidad de aprovechamiento y disfrute, con independencia que la titularidad también lo sea. El problema de la titularidad de esta tipología de bienes ha sido objeto de numerosas dificultades, y ello aunque el art. 2.4 del RB parece claro al señalar que "los bienes comunales solo podrán pertenecer a los municipios y ELM". Además el título de comunero deriva de la condición de vecino, y ésta no es únicamente la del vecino del municipio, globalmente considerado, sino que va a darse en las ELM en los vecinos de la propia pedanía o núcleo de población, situación muy importante en los supuestos de supresión de una ELM (pues si los bienes pasan a ser titularidad del municipio al que pertenece la ELM suprimida, ¿ a qué vecinos nos estaríamos refiriendo en el momento de gestionar el aprovechamiento de dichos bienes?, ¿a todos los del municipio o a los de la desaparecida pedanía?) o en los supuestos de alteración de la calificación de comunal para convertirlos en bienes de naturaleza patrimonial, que requerirá, según mi opinión y veremos más adelante, de la disposición de ambos titulares, entidad local y vecinos.

\section{2.- Diferenciación de otras figuras}

Junto con los bienes que tradicionalmente venimos conociendo como comunales o comunales típicos (como hemos visto aquellos de una entidad local y aprovechados por los vecinos y regulados por normas administrativas), existen otros bienes o derechos cuyo disfrute también corresponde a los vecinos pero con una regulación diferente. Así se reconocen a los bienes comunales atípicos ${ }^{270}$, y que sin ahondar en exceso porque no es el objeto de este trabajo, quiero citar algunos supuestos:

- Bienes y/o aprovechamientos pertenecientes directamente a los vecinos: los montes vecinales en mano común ${ }^{271}$ y las comunidades de pastos y leñas ${ }^{272}$;

\footnotetext{
${ }^{269}$ BOCANEGRA SIERRA, R. op cit. pp. 33.

${ }^{270}$ Procurador del Común de Castilla y León. Informe del año 2011, pág. 8: el conjunto de supuestos agrupados bajo la denominación de bienes comunales atípicos tendrían su origen, en algunos casos, en la compra de los patrimonios que se vendieron durante la desamortización por parte de los propios vecinos, pero constituidos en comunidad vecinal o en formas societarias civiles.

${ }^{271}$ Con su propia regulación prevista en la Ley 55/1980.

${ }^{272}$ Fundamentalmente en montes privados.
} 
- Bienes pertenecientes a personas privadas en los que existen aprovechamientos vecinales $^{273}$;

- Aprovechamientos vecinales en bienes de propios $^{274}$.

A veces la existencia de esta tipología variada de bienes y muy parecida en denominación y caso en gestión y explotación, conlleva numerosos problemas en la aplicación práctica, por eso opino que es muy importante disponer o bien de unos Inventarios Locales bien hechos donde se haya realizado una importante labor de investigación y depuración para saber con seguridad cuál es la naturaleza de los bienes objeto de la controversia, o si no existen inventarios, realizar esa labor mediante un expediente riguroso de investigación.

\section{3.- Regulación de los aprovechamientos comunales mediante ordenanzas especiales}

El artículo 18.1 c) LRBRL recoge que uno de los derechos de los vecinos es “acceder a los aprovechamientos comunales, conforme a las normas aplicables". La regla general por tanto será el disfrute general de todos los vecinos. Sin embargo la normativa permite en determinados supuestos la aplicación de condiciones especiales que deberán cumplir los vecinos para tener derecho a los aprovechamientos y esto acarrea no pocos problemas.

Así las cosas el art. 75.4 TRRL permite la existencia de restricciones en la determinación de los beneficiarios en este tipo de aprovechamientos. Pero es muy importante diferenciar esta posibilidad de restricción ${ }^{275}$, de la forma de aprovechamiento

\footnotetext{
${ }^{273}$ Normalmente supuestos en los que, tras la desamortización, se adquirieron dichos bienes por los vecinos, y se constituyeron en sociedades civiles u otras formas jurídico-privadas. Podemos ver un ejemplo en la Disposición Adicional 10ª de la Ley de Montes del 2003 y DA8 $8^{\mathrm{a}}$ Ley Montes Castilla y León del 2009.

${ }^{274}$ Estos bienes de propios estaban excluidos de la desamortización por estar catalogados, y eran bienes diferentes a los comunales. Se preveía la existencia en montes públicos catalogados de aprovechamientos vecinales - art. 72 y ss y 94 Decreto 17 de mayo de 1865). No debemos olvidar que desde la aprobación de la Ley de Montes 43/2003 los montes catalogados son de naturaleza demanial.

${ }^{275}$ COLOM PIAZUELO, E. "Los bienes comunales en la legislación de régimen local” pág. 109: "La dificultad práctica para distinguir el párrafo segundo y cuarto del art. 75 reside en que, en las ordenanzas que se aprueben como consecuencia del procedimiento establecido en el último de ellos, deben incluirse también los criterios para repartir entre los vecinos elegidos las cortas de madera. Es decir, es preciso que comprendan no solo si los vecinos deben haber residido en el término diez años, por ejemplo, para poder solicitar la parte correspondiente de las cortas de madera, sino también las reglas para conocer si un vecino sólo tiene derecho a medio o a un lote completo.
} 
recogida en el art. 75.2 TRRL, el cual manifiesta como forma de disfrute, cuando no sea posible el aprovechamiento simultáneo (que prácticamente nunca lo es) el aprovecharlo según costumbre u ordenanza local, es decir, poder establecer una ordenanza donde se recoja la forma de distribución o reparto según costumbre.

El problema práctico es que normalmente en cuanto a la fijación de las condiciones de arraigo (que soy de la opinión de que están únicamente previstas para los aprovechamientos leñosos, del art. 75.4 LRBRL) nos encontramos actualmente una tendencia importantísima de poder introducirlas en todas las ordenanzas especiales.

De este modo, la postura del Tribunal Superior de Justicia de Castilla y León es que el art. 75.4 dice claramente que las condiciones especiales son sólo para las leñas o aprovechamientos maderables (como ejemplos puedo citar las STSJ Vallad. 14.2.2006 y 22 de julio de 2008 y 11 de junio de $2010^{276}$ ); la postura del TS versa sobre casos concretos, pero se refiere también a los aprovechamientos de lotes o suertes de cortas de

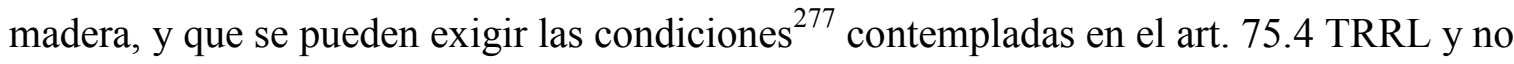
$\operatorname{otras}^{278}$. Pero la postura de la Comunidad Autónoma es, (fundamentalmente para evitar vecindades ficticias) que la regulación de condiciones de vinculación y arraigo lo es para todo tipo de aprovechamientos, y lo que es más, en esa misma postura se mantiene el Consejo Consultivo de Castilla y León ${ }^{279}$ y el Consejo de Estado ${ }^{280}$ (si bien el Consejo de Estado adopta sobre todo criterios de justicia en cada caso concreto ${ }^{281}$ ).

\footnotetext{
${ }^{276}$ Esta sentencia es meridiana al anular una Ordenanza de una Junta Vecinal por regular en la misma aprovechamientos que no son únicamente las suertes o cortas de madera, tal y como recoge el art. 75.4 TRRL, y aplica lo previsto en el art. 75.2 TRRL de manera general. Además también se fundamenta que no se ha seguido el procedimiento previsto en el art. 49 y 70.2 LRBRL y no se ha publicado en el BOP y si en el BOCYL, habiendo sido aprobada por una Orden autonómica, así que mediante otra Orden de la Consejería de Interior de la Junta de Castilla y León, y en ejecución de sentencia, se anual dicha Ordenanza.

277 Así la STS 10 de julio de 1989 rechaza la posibilidad de que un vecino tenga que cumplir los requisitos de ser labrador para poder ser beneficiario.

${ }^{278}$ En la STSJ Castilla y León de 14 de febrero de 2006 se trata del procedimiento a seguir en la tramitación de la ordenanza, y se cuestiona si la misma debe seguir el establecido en el art. 49 LRBRL o no, ya que las ordenanzas especiales han de ser aprobadas por el órgano competente de la CA.

${ }^{279} \mathrm{Su}$ dictamen resulta preceptivo para la aprobación de las ordenanzas especiales en esta materia. Así las cosas, el Dictámen $n^{\circ} 175 / 2011$ respecto a fincas comunales para el aprovechamiento agrícola que es el supuesto más habitual.

${ }^{280}$ Dictamen 1332/2003 para la Ordenanza reguladora de los aprovechamientos comunales de labor y siembra, pastos, hongos, colmenas y caza en terrenos del Ayto. de Riberos de la Cueza (Palencia).
} 
Así las cosas me parece relevante para ilustrar el objeto de la cuestión, recoger algún ejemplo de la casuística más reciente del Consejo Consultivo de Castilla y León, así de este modo en dictamen de fecha 2 de febrero de 2012, en el que se analiza por el órgano consultor, un proyecto de ordenanza reguladora de los aprovechamientos de pastos, leñas y superficies de cultivo de una ELM, se planteó la cuestión de si es posible en una misma ordenanza regular diferentes tipos de aprovechamientos comunales, aspecto que es aprobado por el Consejo Consultivo recomendando "en aras de una mayor seguridad jurídica, que la ordenanza se estructura, diferenciado secciones de aplicación común para todos los aprovechamientos y secciones de aplicación para cada uno de los aprovechamientos que se determinen". Es decir, que el órgano consultivo no solo permite regular en ordenanzas especiales condiciones de vinculación y arraigo para aprovechamientos que no sean únicamente leñosos o de maderas, si no que permite además aprobar ordenanzas donde se regulen en una única disposición varios y diferentes aprovechamientos, como en el supuesto que acabamos de ver (pastos, leñas y roturos) lo cual no deja de llamar la atención.

En este mismo dictamen se fija otra indicación del Consejo y que quiero destacar porque opino que es importante a tener en cuenta para otros supuestos parecidos, y es que la ELM propone que se cree un padrón donde darse de alta para poder disfrutar o tener derecho al aprovechamiento ${ }^{282}$, y el Consejo responde que ya existe el Padrón de Habitantes como registro administrativo donde constan los vecinos y que no es preciso confeccionar un padrón, sino partir del padrón municipal, confeccionando a partir de ahí un listado en el que se incluyan a los beneficiarios que cumplan con los requisitos de permanencia.

Interesante aspecto es el que recoge este mismo dictamen sobre el carácter extraordinario de la cuota a satisfacer para compensar gastos de mantenimiento, conservación y administración de los bienes, aunque sea de naturaleza extraordinaria no es impedimento para que se fije con carácter anual ${ }^{283}$.

Dictamen 09 de abril de 1959: faculta a las entidad local la posibilidad de regula el régimen de sus bienes comunales mediante ordenanza que recoja la costumbre local en un supuesto de cultivo de unas fincas.

${ }^{281}$ COLOM PIAZUELO, E. op cit pág. 113.

${ }^{282}$ En un sentido similar la Dirección de Ordenación del Territorio y Administración Local, en informe de 10 de abril de 2013 sobre Ordenanzas de un municipio, señala que se cambie el término padrón por el de censo correspondiente, para no llevar a equívoco, indicación que es muy positiva desde mi opinión.

${ }^{283}$ Dictamen Consejo de Estado 1332/2003 y 4750/1997. 
En otro dictamen de fecha 31 de marzo de 2011 sobre una ordenanza reguladora del aprovechamiento de las fincas comunales se establece como criterio de permanencia el tener una residencia real y efectiva por un periodo de al menos un año, si bien prevé una excepción que es aplaudida por el Consejo al recoger que "cuando temporalmente por causas externas a su voluntad algún vecino no pueda cumplir con todos los requisitos" para ser beneficiario, prescindiendo del concepto de "fuerza mayor" que es un concepto jurídico indeterminado y que admite diversos sentidos. Me parece una solución acertada la que estima el Consejo puesto que se pueden dar variedad de casuística en estos supuestos y una regulación estricta y poco flexible del concepto de permanencia, llevaría a la ELM a atarse ella misma en la regulación e interpretación de este criterio.

En el dictamen de fecha 1 de julio de 2010 sobre una ordenanza reguladora de aprovechamientos agrícolas se trata la cuestión de la condición de jubilado, recogiendo la costumbre de los agricultores que una vez que se jubilan dejen libres y pongan a disposición de la ELM los "quiñones" adjudicados, para lo cual introduce esta ordenanza el requisito para ser beneficiario de "no percibir pensión de jubilación ni por invalidez permanente". Ante esta regulación el Consejo señala que se oriente a que sea más una causa de resolución o extinción del derecho al aprovechamiento, que un criterio de acceso, aspecto que me parece relevante citar porque es muy habitual encontrar ELM donde se deja fuera del acceso al disfrute de los aprovechamientos a los jubilados, y esta matización que realiza el Consejo me parece muy acertada.

Hay restricciones que se incluyen en las ordenanzas especiales, cuya oportunidad se ha ido perfilando por la doctrina de estos órganos consultivos, y se ha llegado a la conclusión de que no se pueden exigir, destacando algunos tales como:

- Una edad especial, tal y como reconoce el Consejo en dictamen de fecha 23 de octubre de 1986.

- Permanencia en un núcleo urbano concreto dentro del término municipal. Este aspecto se relaciona con los supuestos de disolución de alguna de las Juntas Vecinales titulares de los bienes comunales. Es criticable la falta de regulación legal de las consecuencias de la disolución en relación con la indeterminación de los beneficiarios de los aprovechamientos comunales. No lo regula la 
normativa $^{284}$, no lo suelen recoger los acuerdos de la Comunidad Autónoma de disolución y ahora con la LRSAL tampoco se ha aprovechado para corregir dicha carencia, lo cual no deja de ser una lástima ${ }^{285}$.

El Procurador del Común apuesta y aconseja por la elaboración de las ordenanzas que regulen los aprovechamientos (siempre y cuando se recoja la costumbre aplicable) y no se de así lugar a problemas interpretativos o cambios de criterio, tan habituales y fuentes de problemas en las Juntas Vecinales, opinión que afirmo rotundamente, pues no deja de ser mejor que la costumbre aplicable se recoja en un texto escrito y bien regulado. Por ello destaco algunas de las recomendaciones realizadas por este órgano, tales como:

- No resulta infrecuente que ante la existencia de comportamientos abusivos por los que se declaran vecindades a los únicos efectos de obtener aprovechamientos, se pretendan por las Juntas Vecinales la restricción o limitación a los mismos en criterios que a veces no descansan en la costumbre, aspecto reprobado reiteradamente por la jurisprudencia;

- Que la regulación de condiciones de vinculación y arraigo a recoger en las ordenanzas especiales deben establecerse dentro del marco constitucional de respeto a los principios de igualdad (Dictámenes del Consejo de Estado 210/2001 у CC 337/2005).

En cualquier caso ha de afirmarse la prioridad de la costumbre sobre la Ordenanza, ya que la superior jerarquía normativa de aquélla se desprende de los arts. 75.2 TRRL, a pesar de que el RB en su art. 95 cite primero a aquéllas ${ }^{286}$. Las Ordenanzas deben recoger y respetar la costumbre ${ }^{287}$.

\footnotetext{
${ }^{284}$ En los supuestos de desaparición de EELLMM el titular formal de los bienes pasa a ser el municipio, pero se echa en falta se carece de una norma que permita restringir el derecho al aprovechamiento común a los residentes en el núcleo de la entidad extinguida.

${ }^{285}$ Disposición Transitoria $4^{\text {a }}$ de disolución de las EELLMM.

${ }^{286}$ STS de 25 de octubre de 1995.

${ }^{287}$ STS de 10 de julio de 1989 y más reciente, la STS 17 de febrero de 2012, que se hace eco de la anterior sentencia citada y reivindica el valor de la costumbre como fuente de derecho administrativo y a ser respetada por la ordenanza (pese a que el art. 95 RBEL sitúe en primer lugar a la ordenanza, hay que relacionarlo con el art. 75.2 TRRL). El alto tribunal da un valor de relieve a la costumbre como fuente característica de estos aprovechamientos y hace suyo el fundamento de la STS de 21 de febrero de 2007 la cual afirma: “... la sociedad española ha sido siempre rural y los bienes comunales eran la garantía de la supervivencia de su población [...] es cierto que las circunstancias han cambiado [...] Que la costumbre adquiera rango de norma escrita no le priva de su condición y por ello no permite su modificación sin más, algo que sí sería posible efectuar con cualquier norma jurídica por la voluntad de quien posee, según su rango, potestad para hacerlo. Pero no es ese el caso de la costumbre que sólo puede modificar cuanto mute
} 


\section{4.- Beneficiarios de los aprovechamientos y el problema de las condiciones de arraigo}

De lo expuesto hasta este momento se ha afirmado que los destinatarios de los bienes comunales son los vecinos ${ }^{288}$, es decir, los beneficiarios. Sin embargo y en algunos casos, como hemos visto, la normativa aplicable admite que los municipios puedan exigir otras condiciones para acceder al disfrute de dichos bienes. Y es en la definición o establecimiento de cuáles son o han de ser estas especiales condiciones de arraigo donde encuentro uno de los mayores problemas prácticos en cuanto a la gestión y disfrute de esta tipología de bienes.

El concepto o definición de vecino se halla recogido en el art. 15 LRBRL, como aquellos inscritos en el Padrón de Habitantes de un municipio, por lo tanto son vecinos todas las personas, independientemente de su edad, estado o nacionalidad, y por ello tendrán derecho al aprovechamiento de los bienes comunales, si cumplen con los requisitos fundamentales:

- Residencia habitual en el término municipal en donde se quiera obtener la condición de vecino ${ }^{289}$;

- Inscripción en el Padrón Municipal.

- Aunque la Ley limita el aprovechamiento a los vecinos y en condiciones de igualdad, hay que tener en cuenta que el mismo artículo 18, en su apartado 2, extiende a los extranjeros domiciliados mayores de edad los derechos de los vecinos, y en este sentido el RB se refiere asimismo a los extranjeros domiciliados en el término municipal, en su artículo 103.1.

Respecto de la condición de "vecino", el TC ha considerado que en el concepto de "residencia habitual" $" 290$, que se exige para poder ser beneficiario de tales

\footnotetext{
la "opinio iuris vel necesitatis" de la comunidad que la recibió como tal, y atendidas las circunstancias que así lo demuestren".

${ }^{288}$ Así se afirma también en el artículo 18 c) LRBRL al establecer como uno de los derechos de todo vecino el del acceso a los aprovechamientos comunales.

${ }^{289}$ El vecino no tiene que probar que reside en un término municipal, se presume por la mera inscripción en el Padrón. (art. 16 LRBRL). Si bien dicha presunción admite prueba en contrario, puesto que no son pocos los casos en que la persona figura inscrita en el Padrón de un municipio y reside en otro, es lo que se llama "vecindades ficticias".
} 
aprovechamientos, no sólo se comprende la "residencia efectiva 291 " y el animus manendi (o de permanencia en un lugar), esto es, no sólo la constatación fáctica de la integración en la comunidad local, sino también el ánimo de integración en el pueblo. Por tanto, el concepto legal indeterminado de residencia habitual se refiere tanto a la permanencia en la localidad, desde el punto de vista temporal, como desde una perspectiva de realidad y efectividad. No basta, pues, para acceder al disfrute del aprovechamiento comunal con la simple condición formal de vecino, por la inscripción en el padrón municipal, sino que es preciso, además, que exista una residencia o relación de vecindad efectiva, esto es, un arraigo estable, real y verdadero en la localidad que, en determinadas ocasiones, puede aún restringirse con la imposición de otras exigencias.

El concepto de "residencia habitual" no está definido como tal en la normativa local, y ha sido la jurisprudencia la que ha matizado el mismo (en este sentido la STSJ CYL 18 de octubre de 2001). Así las cosas encontramos un grupo de sentencias del TS como la de 2 de abril de 1990 relativas a problemas creados por la tenencia de un segundo domicilio en otro municipio y la negación de la condición de vecino en el municipio de origen. En estas sentencias (es importante ver el caso concreto) se dice que una cosa es el domicilio y otra la relación de vecindad, siendo posible habitar en otro municipio y conservar la condición si el animus lo justifica, por ejemplo dice la STS que mientras se siga manteniendo en él casa y explotación agrícola. Si bien en otros casos como el que recoge la STS 15 de marzo de 1985 establece que no cumple el requisitos a pesar de figurar la persona en el Padrón, puesto que vive y trabaja en otra localidad, acude al pueblo solo los fines de semana y tiene casa en otra localidad. Hay que ver el caso concreto para poder analizar supuesto a supuesto la condición y concepto de residencia. La STSJ Castilla y León de 11 de noviembre de 2004 establece que el concepto indeterminado de residencia habitual se refiere tanto a la permanencia en la localidad, desde el punto de vista temporal, como desde una perspectiva de realizada y efectividad. No basta la simple inscripción. Y aquí es donde nos encontramos una casuística muy

\footnotetext{
${ }^{290}$ Sentencia TC 308/1994, de 21 de noviembre.

${ }^{291}$ La constatación de la residencia efectiva es relativamente fácil dado que se manifiesta en unos hechos objetivos cuantificables. El animus manendi resulta más difícil de comprobar que se cumpla, sobre todo en casos en que ha existido una ausencia prolongada del término o una doble residencia en dos municipios, aspecto más habitual de lo que se puede pensar. La residencia habitual no se puede interpretar literalmente como una obligación de permanecer todo el año en la población. Se tienen en cuenta otros factores en su conceptuación tales como la profesión, el pago de impuestos, la conservación de propiedades.
} 
variada, pues no puede entenderse como concepto absoluto de residencia habitual el vivir de forma ininterrumpida todo el año en un municipio, pero tampoco admitir el que reside solo en periodos estivales.

Si bien este requisito admite excepciones ${ }^{292}$, en aquellos supuestos donde se presente una causa objetiva, como pueden ser ausencias de carácter temporal causadas por razones de estudio, casos de ausencia por enfermedades... en estos casos hay que extremar el control de dichas ausencias porque algunas serán inaceptables y otras asumibles, mediante un expediente de comprobación y con audiencia a la persona afectada ${ }^{293}$.

En cuanto a la fijación de condiciones especiales se debe señalar que las EELL no pueden exigir otros requisitos complementarios diferentes a los previstos en las normas legales, y que además deben estar vinculadas o deben consistir en perfilar la condición de arraigo, pues no escasos los supuestos en los que lo que se exige no tiene que ver con las mismas, por ejemplo, exigirles que no sean deudores con la entidad local menor. No se puede exigir dicho requisito de estar al corriente de tributos o pagos (ni siquiera incluyéndolo en una ordenanza) diferentes de los generados por el propio aprovechamiento (STS 30 de enero de 1996). Tampoco se puede exigir que la residencia lo sea únicamente en el núcleo urbano, excluyendo a aquellos que residen alejados del mismo, como supuesto que ocurrió en la Junta Vecinal de Calzada del Coto (León).

De la misma manera no se puede admitir como condición para el acceso a estos aprovechamientos la exclusión de vecinos solteros ni tampoco de aquellos que no sean labradores ni ganaderos (STS 10 de julio de 1989 y 3 de octubre de 1991 y TSJ CYL 24 de octubre de 2000: caso en el que se exigía que los vecinos labrasen sus tierras con sus propios medios y con su propio tractor, condición exagerada cuanto menos); ni tampoco por razón de sexo se puede dejar fuera a las mujeres casadas y a las solteras ${ }^{294}$.

\footnotetext{
${ }^{292}$ Es interesante el supuesto recogido en la STSJ 23 de enero de 1996 y la forma de acreditar la prueba en contrario en el caso de un vecino que estaba enfermo y su enfermedad le impedía residir en el pueblo puesto que tenía que estar ingresado por su tratamiento.

${ }^{293}$ Como señala el Procurador del Común en su informe "las cuestiones relativas al cercenamiento de derechos deben ser interpretadas de manera restrictiva, o dicho de otra forma, de manera más favorable a la efectividad de los derechos", y pone como ejemplo la STSJ CYL 15 de diciembre de 1999 en la que se reconoce el derecho al aprovechamiento de pastos y leñas comunales a un vecino empadronado cuya ocupación como transportista le impedía, a juicio de la entidad local, cumplir con el requisito de permanencia, razón por la que había resultado excluido de los aprovechamientos.

${ }^{294}$ La Ley de régimen local del año 1955 recogía en su art. 192 que os aprovechamientos comunales serían para los vecinos cabeza de familia, pero actualmente se ha suprimido tal indicación, pero podría suponer un problema práctico al acumularse dos lotes o más en una única unidad familiar. Así el TS ha interpretado
} 
Así las cosas la expresión o concepto de "cabeza de familia" lo debe ser en consonancia con el espíritu constitucional, considerando la definición de dicho concepto como unidad familiar, lo único que respecto de los solteros deberá precisarse si deben tener casa abierta para poder optar. Esta exigencia de ostentar la cualidad de vecino o cabeza de familia se recoge en varias sentencias del Tribunal Supremo, por ejemplo de 5 de enero de 1968, establece que "es nota caracterizadora de los bienes comunales su destinación a los vecinos".

También es muy frecuente encontrarse con limitaciones tales como el estar dado de alta en la Seguridad Social Agraria y el no ser pensionista, aspectos que no se pueden exigir, y así lo afirma la jurisprudencia ${ }^{295}$.

Un caso más específico lo encuentro en el de los aprovechamientos de leñas: se pueden poner condiciones de arraigo:

- Regulación de las condiciones de permanencia: se pueden evidenciar de diversos modos, refiriéndose a una residencia previa para limitarlo a aquellas que únicamente persiguen un acceso inmediato;

- Regulación de las condiciones de arraigo: se admiten supuestos de restringirlo solo a los descendientes de otras personas con derecho.

También encontramos aquí casuística diversa, como supuestos donde se exige que disponer de casa abierta lo sea en derecho de propiedad, condición que el Consejo de Estado ha reprobado afirmando que era discriminatorio. Otro supuesto discriminatorio es el exigir ser natural de la localidad, si bien el TS señala lo contrario en STS 4 de diciembre de 2007. Este requisito va en contra de criterios de despoblación y dificulta el asentamiento en dichas localidades, pero parece que al final los aprovechamientos quedarían en manos de unos pocos. Por lo tanto y como el único beneficiario deben ser los vecinos, deben ser ellos los que utilicen de forma directa dichos bienes, "sin que se

que dicha restricción al cabeza de familia no es contraria a la CE porque se entiende que el beneficiario lo sería el grupo familiar y no la persona concreta. Sin embargo y en relación al vecino o vecina soltera entiende el TS que sería discriminatorio dejarle fuera por tal condición de estado civil, y asimismo en el supuesto de persona separada (STSJ CYL 21 de enero de 2005).

${ }^{295}$ La STSJ Castilla y León de 22 de julio de 2008 analiza un supuesto donde se establecía como límite de acceso a los aprovechamientos comunales que los mayores de 65 años tuvieran 14 años de empadronamiento. El tribunal muestra su disconformidad al ir dicha medida contra el principio de igualdad del art. 14 CE. En el mismo sentido la STSJ Castilla y León de 31 de mayo de 2001. 
puedan producir cesiones de derechos o subarriendos ${ }^{296,}$, aspecto este último que quiero remarcar porque también es objeto frecuente de consultas por parte de las ELM. Tampoco se puede exigir que sea profesional de la agricultura o de la ganadería.

\section{5.- Utilización de los bienes comunales}

La forma de aprovechamiento de estos bienes viene recogida en la normativa de régimen local sin que se reconozca ninguna especialidad en la normativa autonómica de nuestra Comunidad Autónoma, lo cual sería deseable, dado el gran número de bienes de esta naturaleza existentes en este territorio. Así las cosas se distingue una modalidad principal de aprovechamiento, cual es la explotación común o cultivo colectivo y dos accesorias y subsidiarias ante la imposibilidad de la anterior ${ }^{297}$ : el aprovechamiento peculiar y la adjudicación por lotes o suertes. Sólo en caso de inviabilidad e imposibilidad de utilizar los anteriores cabe la adjudicación mediante precio (STS de 18 de octubre de 1999).

De todos modos en unas $\mathrm{u}$ otras maneras de realizar los aprovechamientos, las EELL están sujetas a las normas técnicas aplicables a cada tipo de aprovechamiento, es decir, en el caso de montes comunales de carácter forestal se aplicará la legislación de montes (art. 38 RB) y en los aprovechamientos cinegéticos la normativa de caza (art. 41 RB) como veremos más adelante.

Es muy importante señalar que las ELM deben seguir el orden establecido de formas de aprovechamiento, así lo ha recordado la jurisprudencia ${ }^{298}$ en numerosas ocasiones. Además el empleo del sistema de adjudicación por precio en Castilla y León

\footnotetext{
${ }^{296}$ Informe Procurador del Común, Diciembre 2011. Pág. 100, y STSJ Castilla y León 8 de marzo de 2005.

${ }^{297}$ La STSJ CYL 16 de enero de 2009 recoge un caso en el que la costumbre que se aprueba por una EL; es "contra legem" puesto que el aprovechamiento privativo en régimen de subasta era la costumbre del lugar, y eso no puede ser si previamente no se ha dejado constancia de la impracticabilidad de la explotación común o colectiva, así que es importante recalcar que no sirve cualquier costumbre, si bien a veces he encontrado supuestos contradictorios y se echa en falta una mayor unanimidad ante estas situaciones.

${ }^{298}$ STSJCYL 13 de octubre de 2000 donde una Junta Vecinal acude al sistema de adjudicación mediante precio sin justificar ni haber intentando las otras formas recogidas en la normativa. En el mismo sentido la STS 3 de mayo de 1989 la cual dice respecto de la elección de los sistemas de aprovechamiento es reglada y que existe un orden de prioridad que no puede ser alterado.
} 
requiere autorización de la Comunidad Autónoma que hoy en día está delegado en las Diputaciones Provinciales mediante Decreto 256/1990. La forma o modo de efectuar el aprovechamiento comunal se regula en el artículo 75 TRRL y se desarrolla por el RB como veremos a continuación.

\subsection{1.- La explotación colectiva o comunal como modalidad de aprovechamiento preferente y general}

Según la ordenación contenida en los preceptos citados, la regla general es que el aprovechamiento y disfrute se ha de hacer "en régimen de explotación colectiva o comunal" (art. 75.1 TRRL), o como de modo similar dice el RB, "en régimen de explotación común o de cultivo colectivo", que consiste, según precisa el propio RB, en su artículo 96, en el disfrute general y simultáneo de los bienes por quienes ostenten en cada momento la cualidad de vecino ${ }^{299}$.

Aun cuando esta normativa no diga de forma expresa que el aprovechamiento colectivo o comunal sea de carácter gratuito, cabe deducir "sensu contrario" esta característica de la regulación que seguidamente se establece para efectuar la adjudicación del aprovechamiento en pública subasta mediante precio (artículo 75.3 TRRL, y 98 RB), o para fijar una cuota anual a los vecinos por la utilización de los lotes que se les adjudiquen, aunque sólo sea para compensar estrictamente los gastos que se originen por la custodia, conservación y administración de los bienes (art. 99 RB). De aquí que quepa mantener la conclusión a que llega Rodríguez Moro ${ }^{300}$ de que este disfrute vecinal simultáneo y gratuito es la norma general para el aprovechamiento de tales bienes ${ }^{301}$.

\footnotetext{
${ }^{299}$ BAZ IZQUIERDO, F. "Explotación colectiva de los bienes comunales de aprovechamiento agrícola" Revista de Estudios Agrosociales, $n^{\circ}$ 51. 1965. pág. 43: recogiendo una opinión de NIETO entiende que la explotación común o colectiva no debe predicarse solo de la posibilidad física o natural, sino también social y jurídica, pues puede darse el supuesto de aprovechamientos colectivos, como pueden ser los leñosos, que por razones de rivalidad, abusos... no puedan ser objeto de esa colectividad y se aconseje pasar al siguiente sistema de aprovechamiento.

${ }^{300}$ RODRIGUEZ MORO, N. “Los bienes comunales de las Corporaciones Locales”, Ed. Abella, 1969, pág. 219.

${ }^{301}$ El disfrute de los pastos puede regularse en cuanto al número de cabezas de ganado y clase de éste que pueda mandar cada vecino; o puede establecerse que las leñas se aprovechen en determinado tiempo y que cada vecino no pueda llevase más de una cierta cantidad, o emplear sólo ciertos y determinados medios humanos y de transporte; o que las hierbas medicinales que da el monte se recoja por cada uno determinada cantidad para mejor repartir y evitar el tráfico lucrativo, etc.
} 


\subsection{2.- Modalidades de aprovechamiento en caso de que el disfrute común fuere impracticable}

En el caso de que no fuere posible, el aprovechamiento de bienes comunales en régimen de explotación colectiva o comunal, que es el más propio y adecuado a su naturaleza, habrá que atenerse de modo subsidiario a las modalidades que el artículo 75.2 y 3 TRRL, en conexión con el 94.2 y concordantes RB, establecen, y que son, siguiendo el orden que la propia normativa recoge, las siguientes:

\section{A) Aprovechamiento peculiar según la costumbre o reglamentación local.}

Cuando existen normas consuetudinarias o una ordenanza local que regulan la forma de llevar a cabo el aprovechamiento de los bienes comunales, estas normas serán de obligado cumplimiento no sólo por la administración sino también por los vecinos al efectuar la utilización. El artículo 95 RB así lo determina al establecer que cada forma de aprovechamiento se ajustará, en su detalle, a las Ordenanzas locales o normas consuetudinarias tradicionalmente observadas, o a las que, cuando fuere procedente, apruebe el órgano competente de la Comunidad Autónoma, en cada caso, oído el Consejo de Estado o el órgano consultivo superior del Consejo de Gobierno de aquélla, si existiera (en Castilla y León como hemos visto el Consejo Consultivo).

En lo que se refiere a la costumbre, la STS de 17 de mayo de 1969 dice que el aprovechamiento ha de ser «según costumbre local» (art. 77 -94 actual, apartado segundo, a, RB), es decir, que ha de resultar, no sólo de un elemento de hecho, el uso, sino además, de un elemento psíquico, la convicción colectiva de su necesidad jurídica, que es el alma de la costumbre, como uso constante y uniforme, elemento cardinal, que es lo que distingue la costumbre del simple uso.

La STS de 10 de julio de 1989, dice que "ha de entenderse que la costumbre tiene prioridad sobre la Ordenanza local. Este es el orden que dibuja el Texto Refundido de 1986, art. 75.2, y aunque el hoy vigente Reglamento de Bienes en su art. 95 incluye en primer término las Ordenanzas y después las normas consuetudinarias, hay que entender como ya se ha dicho que la primacía es la señalada, tanto por el rango legal del Texto 
Refundido como por los antecedentes históricos de la figura que se examina”. En el mismo sentido, las STS de 24 de septiembre de 1993 y de 25 de octubre de $1995^{302}$.

Y por supuesto que la ordenanza ha de desenvolverse en el marco establecido por las leyes, sin que pueda esgrimirse con éxito como dice la STS de 20 de mayo de 1992 el argumento de la autonomía local, puesta que los entes locales han de cumplir las Leyes. En el mismo sentido, la STS de 14 de noviembre de 1995. Lo que ha de entenderse sin perjuicio de que en aquellos aspectos que la propia legislación remite a la Ordenanza local (por ejemplo, lo relativo a cotos y zonas de pastoreo, clases y rotación del ganado, etc.), ésta tiene libertad para precisarlos, si bien que con el límite de las costumbres locales al respecto.

\section{B) Distribución o reparto en "lotes o suertes".}

Si no hubieren normas consuetudinarias o reglamentarias conforme a las cuales efectuar el aprovechamiento ${ }^{303}$ que no ${ }^{304}$ pueda realizarse de modo general y simultáneo, será aplicable lo previsto en el artículo 75.2 TRRL y 97 RB, y en consecuencia la adjudicación del aprovechamiento se hará por "lotes o suertes" a los vecinos, en proporción directa al número de personas que tengan a su cargo e inversa de su situación económica. Ahora bien, es importante recalcar que el reparto efectuado para el aprovechamiento de bienes comunales, no determina, a pesar de no tratarse de una explotación común o colectiva, que los bienes dejen de ser "comunales". Así lo ha declarado la jurisprudencia en numerosas sentencias, afirmando que la adjudicación de lotes o suertes no determina que los bienes pierdan tal calificación de comunales (cito a modo de ejemplo la STS de 9 de enero de 1957, 19 de mayo de 1960, etc.); ni tampoco la

\footnotetext{
${ }^{302}$ La sentencia de 24 de septiembre de 1993 considera, a propósito de la regulación del aprovechamiento de unos pastos, que el campo de maniobra que se otorga a la Administración "encuentra sus límites en la observancia de los usos y costumbres locales" (STS de 24 de septiembre de 1993, ; y la s. de 25-10-1995, reconoce indirectamente la primacía de la costumbre, respecto de la ordenanza local, al decir que es "obligado, para desconocer su eficacia, probar que no se adecuaba a la costumbre local". Sobre la relación entre la costumbre y ordenanzas locales, vid. E. SANCHEZ GOYANES: La potestad normativa del municipio español, de esta Editorial, 2000, pág. 195 y sgs.
}

303 Así, la STS de 3 de diciembre de 1956 dice que si la explotación no se estima practicable y venía repartiéndose el aprovechamiento en lotes por casas, es decir, por «lares»o «fuegos», según la costumbre tradicional, ha de estimarse correcto el acuerdo municipal al efecto.

${ }^{304}$ STSJ Castilla y León de 22 de septiembre de 2006. 
adjudicación del aprovechamiento por lotes o suertes puede servir nunca de base para atribuir derecho de propiedad a los adjudicatarios (STS 30 de noviembre de 1964, etc.). La Sentencia de 31 de diciembre de 1986 dice, con referencia a este supuesto que, los vecinos disfrutan los bienes en nombre del Ayuntamiento como propietario, y los poseen al modo en que lo hace un arrendatario o precarista en nombre del titular; y como no pueden ser poseídos a título de dominio, los actos que pueden ejercitar sobre ellos son de simple disfrute y el Ayuntamiento solamente vendrá obligado a cumplir con las condiciones de la norma reguladora del disfrute, sin necesidad para recuperarlos de ejercer acciones de reivindicación, no pudiendo el que las disfruta acceder a su propiedad ni a través de una posesión, que no tiene título de dueño, ni del ejercicio del derecho arrendaticio de accesión a la propiedad incompartible con la naturaleza de los bienes comunales que son inalienables, imprescriptibles e inembargables... En el mismo sentido, la STS de 24 de enero de 1989.

En este tipo de reparto, y de modo excepcional, cabe la posibilidad de establecer por parte de la ELM una cuota anual por el aprovechamiento de lotes ${ }^{305}$. En este supuesto, la cuota, que ha de ser anual, tiene que fijarse atendiendo sólo a los gastos que se ocasionen por estos conceptos, custodia, conservación y administración, y sólo podrá fijarse de modo excepcional, por alguna causa justificada, siendo necesario que el acuerdo de la ELM se adopte con el quorum que el precepto establece en conexión con el artículo 47.3. d) LRBRL, pues son numerosos los supuestos en los que no se regula de esta manera.

\section{C) Adjudicación del aprovechamiento de bienes comunales mediante precio.}

Esta es la última posibilidad que, en un orden de prelación sucesivo, prevé el artículo 75.3 TRRL, en relación con el 94.3 y 98 RB. Si ninguna de las modalidades anteriores fuera posible, se efectuará la adjudicación del aprovechamiento de bienes

\footnotetext{
${ }^{305}$ A esta posibilidad se refiere el artículo $99 \mathrm{RB}$, según el cual en casos extraordinarios, y previo acuerdo municipal adoptado por la mayoría absoluta de número legal de miembros de la Corporación, podrá fijarse una cuota anual que deberán abonar los vecinos por la utilización de los lotes que se les adjudiquen, para compensar estrictamente los gastos que se originen por la custodia, conservación y administración de los bienes.
} 
comunales "mediante precio 306 ". Para ello, se requiere que lo autorice el órgano competente de la Comunidad Autónoma según las normas de organización de la respectiva Comunidad ${ }^{307}$ - y que, una vez autorizado ${ }^{308}$ el aprovechamiento de esta forma, la adjudicación del mismo se efectúe mediante subasta pública en la que, en igualdad de condiciones, se otorgue legalmente preferencia a los postores que son vecinos sobre los que no son residentes en el municipio. Aunque el Reglamento nada dice sobre el plazo para hacer efectiva esta preferencia, creemos con Rodríguez Moro ${ }^{309}$ - que debe hacerse en el mismo acto de la apertura de plicas, recogiéndose en el acta que se levante, esta incidencia, además de cuanto consigna dicho artículo. En el caso de que fueren varios los vecinos postores que hagan uso del derecho de preferencia, es tradicional (y así aparecía en el art. 34 RCL de 1953) que se abra entre ellos licitación verbal por "pujas a la llana" y si subsistiere el empate, una vez pasado el tiempo fijado por la Mesa, se hará por sorteo la adjudicación provisional (a reserva de la aprobación municipal del Pleno de la Corporación).

En caso de que no hubiera licitadores, la adjudicación, como es lógico, podrá hacerse de forma directa (art. 98.2 RB). Y en cualquier caso, según determina el artículo 98.3 RB, el producto se destinará a servicios en utilidad de los que tuvieren derecho al aprovechamiento, sin que pueda detraerse por la Corporación más de un 5 por 100 del importe. Como lo normal será que a estos bienes comunales tengan derecho todos los vecinos del término, resultaría en tal caso inútil el precepto. En cambio, cuando el disfrute del bien de que se trate corresponda a un núcleo vecinal (lugar, aldea, anejo, etc.), no constituido en entidad local menor, entonces habrá de aplicarse el precepto mencionado,

\footnotetext{
${ }^{306}$ No se puede acudir, por ello, al sistema de subasta sin acreditar previamente que las modalidades anteriores no fueran viables (STS 18 de octubre de 1999). Aquí radica a veces el problema de determinar o acreditar que la forma colectiva de aprovechamiento no es posible. Pues se puede pensar que la practicabilidad no es únicamente física, sino también jurídica o social, pues puede darse el supuesto de aprovechamientos colectivos que por circunstancias locales (abusos, rivalidades etc....) sean difícilmente practicables.

307 En Castilla y León el Decreto 256/1990, de 13 de diciembre, delegó dicha competencia en las Diputaciones Provinciales.

${ }^{308}$ El Dictamen del Consejo de Estado ${ }^{\circ} 235 / 1995$ en el que se analiza la conveniencia de obtener una mayor rentabilidad de unos aprovechamientos maderables, sustituyendo el sistema de reparto por lotes por la distribución del producto de la enajenación de la madera, considerando esta opción razonable, ya que el Consejo afirma que supone una importante economía de escala y que lo que se trata de enajenar no es el aprovechamiento, si no su producto, pues en el caso contrario no cabria la autorización.
}

${ }^{309}$ Op. Cit, pág. 243. 
viniendo obligado el Ayuntamiento a invertir el importe de las subastas en servicios que afecten a dicho núcleo vecinal, sin que el Ayuntamiento pueda detraer más del 5 por 100 para sus arcas, en pago de gastos generales que al mismo se le ocasionen.

\section{6.- Supuestos de alteración de la calificación jurídica de los bienes comunales}

Me gustaría reseñar algún supuesto en el que nos encontramos que la ELM ante la problemática ocasionada por querer proceder a un reparto comunal de bienes que no ostentan dicha naturaleza, han llevado a cabo expedientes de alteración de la calificación y afectación de dichos bienes patrimoniales a comunales. Dichos expedientes en principio no conllevan ningún problema reseñable, no existe una regulación específica para ellos por lo tanto hay que aplicar las reglas generales sobre afectación al dominio público. Pero sí es importante remarcar que existe un supuesto concreto en el que dichas entidades se están basando para proceder a la nueva afectación y es el que señala que la adscripción de bienes patrimoniales a un uso o servicio público o comunal, por más de 25 años por parte de la entidad local estuviera destinada a usos comunales. En este supuesto no se necesita ni la recepción del bien ni expediente concreto.

Sin embargo con la desafectación la normativa local contiene unas reglas más estrictas y restrictivas respecto de la desafectación de los bienes comunales, que por su naturaleza intrínseca o por otras causas no hubieran sido objeto de disfrute durante más de 10 años. En este caso se necesita trámite de información pública, y acuerdo con el voto favorable de la mayoría absoluta del número legal de miembros de la corporación y posterior acuerdo de la Comunidad Autónoma (actualmente de las Diputaciones Provinciales en Castilla y León ${ }^{310}$ ). Además se necesita recepción formal del bien comunal desafectado para su incorporación al patrimonio de la ELM, pues en tanto no tenga lugar dicha recepción formal el bien seguirá teniendo carácter comunal.

Por otra parte quiero indicar que según algunos autores ${ }^{311}$ y yo comparto dicha teoría, en los supuestos de desafectación de los bienes comunales, ya sea mediante

\footnotetext{
${ }^{310}$ Por delegación de la Consejería de Presidencia mediante Decreto 256/1990, de 13 de diciembre.

${ }^{311}$ BOCANEGRA SIERRA, R. op cit pp. 70 y ss.
} 
expediente o mediante desafectación tácita, debería quedar acreditado que, por la condición de doble titularidad o titularidad compartida que tienen dichos bienes, se exija la concurrencia de las voluntades de ambos cotitulares.

Un problema que he encontrado a veces en la práctica es que la afectación de un bien a un aprovechamiento comunal no implicaría necesariamente que todas las utilidades posibles tengan que beneficiar a los vecinos. En ambos casos de afectación, expresa y por el trascurso del tiempo, se presupone que todos los aprovechamientos deben beneficiar a la comunidad de habitantes una vez calificada la propiedad como comunal. Pero la situación en verdad es diferente, ya que cuando el proceso se produce por una resolución expresa en la misma se pronuncia sobre el destino de todos los aprovechamientos incluidos en dicho bien, el asunto es más complejo cuando la afectación se produce de manera presunta, ya que no hay un acto que concrete el régimen de los diversos disfrutes, de tal manera que nos podemos encontrar casos en que ciertas utilidades secundarias como la caza no benefician a los habitantes de la localidad. El problema es saber si esos aprovechamientos secundarios que no eran vecinales y que no justificaron el cambio de naturaleza del bien, deben adaptarse a las nuevas reglas ${ }^{312}$. No se debe olvidar que en un bien pueden confluir diversos aprovechamientos (caza, pastos, leñas...) y que la mayoría no tiene un régimen similar.

\section{7.- Confluencia de bienes comunales con otro tipo de aprovechamientos}

En algunas ocasiones existen aprovechamientos especiales, así en el art. 106 RB se dice que una parte de los bienes comunales podrá ser acotada para fines específicos, tales como enseñanza, recreo escolar, caza o auxilio a los vecinos necesitados, y dichas acotaciones se regularán por su normativa sectorial aplicable. Dentro de este apartado se destaca como aprovechamiento no vecinal sobre bienes comunales el que muy habitualmente se realizad de la riqueza cinegética. Dicho aprovechamiento se regula por su legislación especial (art. 41 RB). La existencia de estos aprovechamientos no afecta a

312 COLOM PIAZUELO, E. op. cit pág. 276 este autor afirma que si no ha habido afectación expresa, los disfrutes secundarios no comunales seguirán rigiéndose por las mismas normas, dado que no ha habido un cambio formal de su naturaleza y que en el inventario continuarán normalmente como bienes de propios. 
la calificación del bien como comunal, en la medida que pueden responder a disfrutes de carácter o naturaleza menor.

Uno de los casos más habituales es la constitución de cotos privados de caza donde se integran terrenos comunales. En dichos cotos puede no existir participación alguna, ni directa ni indirecta, de los vecinos en los aprovechamientos cinegéticos de esos terrenos, dando lugar a que se de la contradicción de disponer de unos terrenos comunales pero no poder imponer al titular del coto privado de caza el acceso de todos los vecinos al aprovechamiento cinegético.

Así las cosas y ante este habitual problema, quiero hacer mención de la doctrina de solución planteada por el Procurador del Común que reza como soluciones alternativas ante esta situación, las cuales me parecen muy interesantes y procedentes:

- Garantizar el acceso de todos los vecinos a los rendimientos económicos generados por el aprovechamiento cinegético de los bienes comunales de la entidad local $^{313}$;

- Modificar la calificación a efectos cinegéticos de los terrenos comunales de la entidad local ${ }^{314}$;

- Modificación de la calificación jurídica de los terrenos comunales para convertirlos en patrimoniales ${ }^{315}$ (ver capitulo anterior).

\section{3.- LOS MONTES}

\subsection{Las competencias locales en materia forestal}

La Ley 43/2003 de Montes (LM) otorga a las EELL una mayor participación en la adopción de las decisiones que directamente les afectan sobre sus propios montes. Ellas

\footnotetext{
${ }^{313}$ Dice el informe citado que la forma jurídica sería estableciendo un contrato con el titular del coto de caza y la entidad local en virtud del cual se arrendaría el aprovechamiento cinegético de los terrenos comunales a cambio de una contraprestación económica a abonar por al titular del coto. El destino de esa contraprestación económica debería ir al común de los vecinos de la localidad.

314 Artículo 21 Decreto 83/1998, de 30 de abril, que dispone que: "los cotos de caza podrán sufrir reducciones en su superficie, mediante segregación de parte de los terrenos que lo componen, siempre que la superficie resultante siga cumpliendo las condiciones impuestas en el art. 17 de dicho Decreto".

${ }^{315}$ Artículo 78 TRRL.
} 
son los principales propietarios de los montes públicos y su contribución a la conservación de estos recursos naturales beneficia a toda la sociedad. Las ELM ostentan competencias que afectan al ámbito forestal y en concreto tienen facultades de ordenación, explotación y mejora de sus bienes previstas en el art. 84 TRRL y en los arts. 38 a 40 RB. No debemos olvidar que la LM en su art. 9 determina que las entidades locales, en el marco de la legislación básica del Estado y de la legislación de las CC.AA, ejercen las siguientes competencias:

a) la gestión de los montes de su titularidad no incluidos en el Catálogo;

b) la gestión de los incluidos en el Catálogo si así lo dispone expresamente la legislación forestal de su Comunidad Autónoma;

c) la disposición del rendimiento económico de los aprovechamientos forestales de todos los montes de su propiedad, sin perjuicio de lo dispuesto en el art. 38 de la LM en relación con el fondo de mejora de montes catalogados en la cuantía que fijen las CC.AA y que en todo caso no será inferior al 15\% de valor de los aprovechamientos;

d) la emisión de informe preceptivo en el procedimiento de elaboración de los instrumentos de gestión relativos a los montes de su titularidad incluidos en el Catálogo;

e) la emisión de otros informes preceptivos previstos en la Ley relativos a los montes de su titularidad.

A nivel autonómico en Castilla y León se dispone de ley propia de montes, la Ley 3/2009, de 6 de abril que dispone que son de dominio público o demaniales e integran el dominio público forestal:

a) Por razones de servicio público, los montes incluidos en el Catálogo de Montes de Utilidad Pública a la entrada en vigor de esta Ley, así como los que se incluyan en él de acuerdo con el artículo 11.

b) Los montes comunales ${ }^{316}$, pertenecientes a las entidades locales, en tanto su aprovechamiento corresponda al común de los vecinos.

c) Aquellos otros montes que, sin reunir las características anteriores, hayan sido afectados a un uso o servicio público.

316 GARCIA ASENSIO, J.M. "Sistemas vecinales de ejecución de los aprovechamientos forestales comunales en Soria y Burgos". Revista Aragonesa de Administración Pública no 18. Junio 2001. "Son llamativos los casos de la comarca de Pinares en Soria y la de la Sierra en Burgos, que se caracterizan por una densa masa forestal y dichos montes han tenido siempre la consideración de bienes comunales. 
Son montes patrimoniales los de propiedad pública que no sean demaniales. Asimismo establece que tienen la condición de aprovechamientos forestales los maderables y leñosos, incluida la biomasa forestal, los de pastos, la resina, la actividad cinegética, los frutos, los hongos, el corcho, las plantas aromáticas, medicinales y melíferas y los demás productos y servicios con valor de mercado característicos de los montes.

Hasta aquí nada diferente de la regulación estatal. Los problemas surgen cuando se conjugan en los montes de UP, los aprovechamientos comunales, y sobre todo estoy observando que los supuestos más habituales y problemáticos son los casos de "roturos". Es el art. 48 de la LMCYL el que regula la situación a seguir antes estos supuestos y dice que los aprovechamientos en montes catalogados de utilidad pública que se vengan realizando de acuerdo con lo dispuesto en ordenanzas locales o normas consuetudinarias, continuarán ajustándose a ellas en cuanto no se opongan a lo establecido en la legislación vigente, o a los instrumentos de planeamiento $\mathrm{u}$ ordenación forestal. En caso de discordancia, las ordenanzas locales deberán modificarse para adaptarse a la legislación o a los instrumentos reseñados. Y además que en los procedimientos de elaboración de aquellas ordenanzas, será preceptivo el informe de la consejería competente en lo relativo a aspectos técnicos de su competencia, debiéndose comunicar el proyecto de ordenanza tras el trámite de aprobación inicial por la entidad local.

En cuanto al sistema de gestión de los montes, la LM en su art. 15 dice que la Administración gestora de los montes, es decir la CA, someterá a otorgamiento de autorizaciones aquellas actividades que la requieran por su intensidad, y a concesión si implican una utilización privativa del dominio público foresta.

Los Montes UP son clasificados, como hemos visto, como bienes demaniales ${ }^{317}$, y de igual forma los bienes comunales ${ }^{318}$. Pero una cosa es el régimen jurídico y naturaleza de los bienes y otra distinta la forma de su aprovechamiento ${ }^{319}$. Cada uno tiene sus

\footnotetext{
${ }^{317}$ BARCELONA LLOP. J. en “Comentarios sistemáticos a la Ley 43/2003 de Montes”. Pág. 885.

${ }^{318}$ Vid. BLANCO HIGUERA, A.L. "La propiedad pública de los montes como condición necesaria para su catalogación, antes y después de la Ley de Montes de 2003". Revista jurídica de Castilla y León $n^{\circ} 30$. 2013, sobre el tema del cambio de naturaleza de patrimonial a demanial con la aprobación de la Ley de Montes de 2003.

319 BARCELONA LLOP, J. op cit. "la regulación de los usos en el dominio público forestal (art. 15) no debe confundirse con la de los aprovechamientos forestales (art. 36 a 38). Ambos responden a lógicas diferentes. Los aprovechamientos su motor es la obtención de rendimientos de los frutos del monte, en
} 
normas en función de su naturaleza, por ello los Montes UP no asumen las formas clásicas de utilización de los bienes de dominio público en su totalidad (autorización o concesión demanial).

Los aprovechamientos no requieren ni autorización ni concesión, de hecho, el art. 15.3 LM establece que "sin perjuicio de lo dispuesto en el apartado anterior los aprovechamientos forestales en el dominio forestal se regirán por lo que se establece en los art. 36 y 37 LM". Y el art. 36.4 LM determina que los aprovechamientos en los montes de dominio público podrán ser enajenados por sus titulares en el marco de lo establecido en el art. 15 LM, así como en lo previsto en la legislación patrimonial que les sea de aplicación. Y de igual forma el art. 45.5 LMCYL remite a la legislación sobre patrimonio y contratación.

En este cúmulo de remisiones de ambos sectores normativos y que entiendo no son excluyentes, que se complementan y que ambos son de aplicación, me parece capital resaltar, dado el carácter de legislación básica de la LM, la indicada Disposición derogatoria única apartado 2, que prevé la vigencia de las anteriores noemas reglamentarias en tanto no se opongan a lo dispuesto en la LM. Ello quiere decir que se mantiene por el momento el RM cuyo art. 213 y 265 remite a la legislación de régimen local sobre administración del patrimonio y contratación. Por lo tanto la regla general para la contratación de aprovechamientos así como la adjudicación de roturos como ya es tradicional en nuestra legislación sobre montes públicos y así se ha corroborado por la jurisprudencia del TS, es la subasta y el contrato resultante de la misma tiene carácter administrativo especial, esta es la conclusión que mantengo respecto de esta situación tan habitual $^{320}$. Y si además el aprovechamiento tiene carácter comunal se deberán seguir las precisiones vistas en los capítulos anteriores para la utilización de los bienes comunales vistas en el capítulo anteriormente analizado.

\footnotetext{
cambio la idea que inspira el régimen de los usos del dominio público forestal es otra, siguiendo la opinión de este autor que comparto, los usos se identifican con las actividades que se realizan en el monte de dominio público per que no persigue la aprobación y explotación económica de los frutos que produce, es importante reseñar esto porque habitualmente las ELM no distinguen entre uno y otro concepto.

${ }^{320} \mathrm{Y}$ en apoyo de esta solución procede citar los art. 267, 269,270, 271.2, 272.1 y 273.1 del RM y art. 4 letras o) y p) TRLCSP que excluye del ámbito de aplicación del mismo las autorizaciones y concesiones sobre bienes de dominio público y contratos de arrendamiento y análogos sobre bienes inmuebles.
} 
Como novedad quiero destacar que recientemente la LMCYL ha sido modificada y se ha establecido una nueva redacción del art. 47 que prevé que: "Para facilitar la tramitación de los procedimientos de enajenación de productos forestales, la consejería competente en materia de montes podrá formalizar acuerdos con las entidades propietarias de montes catalogados que la habiliten para tramitar dichos procedimientos" ${ }^{321}$, medida que debe recibir una posición positiva al intentar ayudar en la gestión de dichos aprovechamientos a las entidades más necesitadas o con menos medios materiales para la tramitación de dichos procedimientos.

\subsection{Los aprovechamientos forestales y su gestión}

Por lo que hace referencia a los aprovechamientos forestales la LM en su art. 36.1 establece, como acabo de exponer, que corresponde al titular del monte en todos los casos el propietario de los recursos forestales producidos en el mismo, incluso los frutos espontáneos, teniendo derecho a su aprovechamiento. Estos aprovechamientos se realizarán de acuerdo con las prescripciones para la gestión de los montes que se hubieran establecido en los correspondientes planes de ordenación de los recursos forestales, cuando existan, así como el resto de instrumentos de ordenación forestal.

El órgano forestal de cada CA regula los aprovechamientos no maderables. Estos aprovechamientos, y en especial el de pastos, deberán estar expresamente regulados en los correspondientes instrumentos de gestión forestal. Por lo que se refiere a los aprovechamientos maderables y leñosos deberán también ser regulados por el órgano forestal de la CA.

En todo caso las ELM titulares de montes catalogados aplicarán a un fondo de mejora, cuyo destino será la conservación y mejora de los montes incluidos en el Catálogo, una cuantía que fijará la CA y que nunca será inferior al 15\% del valor de sus aprovechamientos forestales o de los rendimientos obtenidos por ocupaciones $\mathrm{u}$ otras actividades desarrolladas en el monte. El fondo será administrado por el órgano forestal de la CA, salvo que esta los transfiera a la entidad local titular.

${ }^{321}$ Ley 11/2013 de 23 diciembre, de Medidas Tributarias y de Reestructuración del Sector Público Autonómico con entrada en vigor el 1 de enero de 2014. 
Aprovechamientos forestales lo son todos los relativos a los montes, cualquiera sea el producto extraído, pero en sentido estricto solo son productos forestales los que de verdad produce el monte: arbolado, madera, leñas, pastos. Existen otros aprovechamientos que se dan en el monte pero que no son del monte o se encuentran en él (caza, aguas, pesca etc.).

La ELM propietaria, al igual que las demás administraciones, no puede aprovechar directamente sus montes. Rige el principio del "contratista interpuesto". La Administración ha de contratar la realización de los aprovechamientos de acuerdo con los pliegos de condiciones técnico facultativas, jurídicas y económicas convenidas. Rige, sobre la base de la legislación especial de montes, el principio de subasta necesaria, salvo lo que puedan establecer las Leyes o los Reglamentos aprobados por las CC. AA.

Llegados a este punto, es importante que exponga unas reflexiones ante la gestión de los montes por parte de las ELM:

$1^{\circ}$ Que las condiciones técnico-facultativas son establecidas por la Administración forestal incluso los precios mínimos y los índices. Son precios mínimos los de tasación fijados para cada producto teniendo en cuenta los vigentes en el mercado. El precio índice es superior al mínimo y por encima de él no puede la ELM ejercer el derecho de tanteo o auto adjudicarse los aprovechamientos.

$2^{\circ}$ Las condiciones económicas son determinadas por las ELM en los términos prevenidos en la legislación local y contractual, pero son nulas las que se opongan a las técnico-facultativas.

$3^{\text {o }}$ Los aprovechamientos que vengan realizándose conforme a normas consuetudinarias o reglamentarias locales (Ordenanzas de aprovechamientos comunales) deberán ser respetados, adaptándose en su caso las respectivas Ordenanzas.

$4^{\mathrm{o}}$ Ningún aprovechamiento puede ponerse en práctica antes de que la licencia de disfrute haya sido expedida por la administración forestal, previo cumplimiento de los requisitos establecidos en el art. 216 del Decreto 485/1962 Reglamento de Montes (RM).

$5^{\circ}$ Conforme a la legislación de montes y, en concreto, en base a su Reglamento, si se declara desierta una subasta por falta de licitadores ha de anunciarse una segunda y hasta una tercera, si bien en este último caso puede optarse por la contratación directa. Esta regulación no armoniza con la contenida en el TRLCSP. El problema radica en si ha de prevalecer la normativa especial de montes sobre la general posterior de contratación 
en la que una sola subasta desierta autoriza a utilizar el hoy llamado procedimiento negociado.

$6^{\circ}$ Las ELM pueden adjudicarse, ejercitando el derecho de tanteo, los aprovechamientos de montes de su propiedad, si la subasta se declara desierta o si ninguno de los licitadores rebasa el precio índice.

$7^{\circ}$ Que respecto de los aprovechamientos forestales, tanto la legislación de montes (especialmente el RM) como el RB establecen el principio de subasta necesaria, como forma de adjudicación.

$8^{\circ}$ Por mandato del art. 36.4 LM el régimen jurídico de los aprovechamientos en los montes de dominio público forestal, además de la LM, lo será por la normativa patrimonial (art. 94 y ss RB) estableciendo que el aprovechamiento y disfrute de bienes comunales se efectúa según los sistemas vistos en el capítulo por el orden de preferencia visto en los capítulos anteriores.

$9^{\circ}$ Los aprovechamientos especiales no propiamente forestales, entre ellos los pastos, deben sujetarse (plazos, precios, fechas de entrada o acotamiento etc..) a las limitaciones establecidas en los correspondientes planes de ordenación de recursos forestales, cuando existan, en el proyecto de ordenación de montes o instrumento de gestión equivalente que establezca la administración forestal y a las prescripciones técnico -facultativas y económico administrativas fijadas en el art. 46 LMCYL.

$10^{\circ}$ En los aprovechamientos de pastos, los no destinados a uso propio de los vecinos serán considerados sobrantes y en su adjudicación eran de aplicación las reglas de preferencia establecidas en el art. 27 Ley 1/1999, de 4 de febrero de Ordenación de los Recursos Agropecuarios Locales y de la Tasa por aprovechamiento de los Pastos, Hierbas y Rastrojeras (art. 53.2 LMCYL) ${ }^{322}$ - Ley derogada recientemente por la Ley $1 / 2014$, de 19 de marzo, Agraria de Castilla y León-.

$11^{\mathrm{o}}$ Todos los contratos de aprovechamientos de productos forestales de los

\footnotetext{
322 Existían algunas opiniones discordantes con este criterio, al entender que el art. 53 LMCYL con relación al art. 27 Ley 1/1999 de Ordenación de los Recursos Agropecuarios Locales y de la Tasa por aprovechamiento de los Pastos Hierbas y rastrojeras, la normativa estatal LM y RM y la de los bienes locales prevalece sobre la pretendida aplicación del art. 53 LMCYL por su carácter básico. La Ley 1/1999 entienden algunos, no es aplicable dado que la misma solo se aplica como prevé su art. 1 al régimen de ordenación común de pastos y que precisen de una forma de gestión colectiva.
} 
montes catalogados (son bienes de dominio público), han de ser considerados como contratos de naturaleza administrativa especial ${ }^{323}$.

\section{3.- Aprovechamientos especiales}

Se consideran como tales aquellos no propiamente forestales que tienen lugar en el monte pero que no son estrictamente aprovechamiento exclusivo de los mismos. Aludiré solo a los específicamente locales:

$1^{\circ}$ Pastoreo: Se permite si es compatible con la conservación del arbolado, prohibiéndose en caso contrario. En los montes de utilidad pública catalogados de las ELM se atenderá en primer lugar al mantenimiento del ganado de los vecinos; pero en todo caso conforme al art. 36.3 de la LM el órgano forestal debe regular en particular el aprovechamiento de los pastos en los correspondientes instrumentos de gestión forestal.

$2^{\circ}$ Caza en los montes de las ELM: Si se trate de bienes de propios o comunales la caza puede ser objeto de contratación, pero si se trata de montes catalogados el aprovechamiento de la caza debe figurar en el plan anual de aprovechamientos e incluso someterse a las prescripciones que en materia de su competencia dicte la Administración forestal.

$3^{\text {o }} \operatorname{Setas}^{324}$ : el aprovechamiento micológico en la comunidad de Castilla y León se regula por el Decreto 130/1999, de 17 de junio, en los montes, distinguiéndose los siguientes aprovechamientos (que a menudo son indistintamente utilizados por las ELM y confundidos sus conceptos):

\footnotetext{
${ }^{323}$ Así lo indicó el TS en sentencia de 22 de junio de 1992 al hacer énfasis en el carácter exorbitante de las cláusulas.

${ }^{324}$ Las setas no tienen una reglamentación sanitaria específica, es dispersa y poco concreta y se refiere únicamente a las normas de calidad de las setas cultivadas, del champiñón y de las trufas. Prohíbe mezclar especies diferentes, venderlas troceadas, las clasifica por categorías según tamaño y calibrado, también prohíbe técnicas o tratamientos para "desintoxicar" setas venenosas. Las setas en el momento de su venta deben estar exentas de gusanos, moluscos e insectos y sus larvas, no deben contener residuos de metales pesados ni restos de pesticidas, debiendo pasar un examen facultativo aunque en la legislación no se indica quién deberá realizarlo.
} 
- De carácter comercial o vecinal: por cualquier forma de licitación deberán aparecer incluidos en el Plan Anual de Aprovechamientos y están sujetos a autorización administrativa. Se pueden acotar y señalizar.

- Recolección con fines científicos: con autorización del propietario del terreno ya acreditando tal fin.

- Recolección episódica: si no existe aprovechamiento comercial o vecinal, solo se podrá realizar de forma episódica respetándose la voluntad de los propietarios del terreno de no permitir la recogida de setas en terrenos de su propiedad. Los propietarios fijaran los máximos recolectables por persona y día, superando estas cantidades se considerará aprovechamiento comercial, y aquí es donde entra el aspecto más problemático que es que las entidades locales propietarias podrán regular mediante Ordenanzas la recolección consuetudinaria episódica de las setas, ordenanzas municipales (entendemos que querrán decir locales) deberán ser comunicadas a las Delegaciones Territoriales y publicadas conforme a ley.

\section{4.- RESUMEN}

Los problemas derivados de la conjunción de las distintas naturalezas de los bienes en el caso de la explotación y uso de los montes de U.P. (de carácter demanial desde el año 2003) con la superposición de la naturaleza comunal de los aprovechamientos (que incluso pueden ser varios en un mismo monte, desde los llamados "roturos" o aprovechamientos agrícolas, que si bien no tienen carácter de aprovechamiento forestal se efectúan sobre terreno del monte, hasta los pastos, setas etc...) obligan a establecer unos criterios consensuados en nuestra Comunidad Autónoma ante las impugnaciones realizadas por la misma en su labor de control de legalidad prevista en los art. 65 y ss de la LRBRL, ya que si no está debidamente acreditada la naturaleza comunal (porque no viene así recogida en los inventarios municipales o no se ha podido acreditar tras el transcurso del tiempo recogido en las actas municipales, evitando cambios volubles en la forma de explotar dichos bienes), se está dudando del carácter comunal de dichos bienes y quizás se debiera proceder a definir la alteración de la calificación jurídica del bien (art. 8.4 RBEELL) hacia su carácter comunal (por otra parte esa creencia en que esos aprovechamientos tienen carácter comunal o vecinal viene apoyada por la junta de Castilla y León pero en su vertiente de la Dirección de Medio 
Ambiente, al confeccionar los pliegos de prescripciones técnicas que han de regir la gestión del Monte al ser catalogado, y eso está siendo también fruto de discrepancias dentro de la misma comunidad autónoma) ${ }^{325}$.

Por otra parte la exigencia y el uso continuado de condiciones de vinculación y arraigo en el reparto comunal de diversos bienes y aprovechamientos, necesita e impone de la existencia de una ordenanza que recoja dicha costumbre. Sería adecuado para superar los problemas que esta situación ocasiona el proponer un modelo-tipo de Ordenanza reguladora de aprovechamientos comunales que, posteriormente adaptada a los criterios y costumbres de cada localidad, sea aprobada por la Junta de Castilla y León previo dictamen del Consejo Consultivo de Castilla y León y permitiera de este modo la caracterización de esas exigencias a los vecinos del pueblo.

\footnotetext{
${ }^{325}$ A favor de la creencia de que esos terrenos de los Montes de UP son de carácter comunal a la vez lo apoya BLANCO HIGUERA, A.L. "La imprescriptibilidad de los bienes comunales: su trascendencia para la conservación de la propiedad forestal pública". Revista Jurídica de Castilla y León, $n^{\circ} 32$. Enero 2014. Valladolid. Pág. 27: El patrimonio municipal comunal está constituido casi en su totalidad por montes, generalmente catalogados; vid. DÍAZ Y DÍAZ-CANEJA, José (1955), pp. 432 y 436. Los montes municipales constituirían la mayoría de los bienes de los municipios; vid. SIEIRA BUSTELO, Constantino (1956), «Distinta titularidad de los montes incluidos en el Catálogo de Montes de Utilidad Pública. Su naturaleza jurídica», en Revista de Estudios de la Vida Local, núm. 86, Madrid, p. 160. La mayor parte de los bienes comunales - por no decir todos- estarían constituidos por montes catalogados, pues precisamente eran los terrenos de aprovechamiento común, entre otros, los que debían quedar exceptuados de la venta durante el proceso desamortizador; vid. SIEIRA BUSTELO, Constantino (1956b), p. 381. La mayoría de los bienes municipales estarían integrados por montes catalogados, que podían ser de propios y comunales; vid. CUADRADO IGLESIAS (1980), p. 190. Los montes comunales no serían sino los bienes comunales susceptibles de encajar en el concepto de monte; vid. CALVO SÁNCHEZ, Luis (2005), «El dominio público forestal y los montes patrimoniales», en AA.VV., Comentarios sistemáticos a la Ley 43/2003, de 21 de noviembre, de Montes (Estudios de Derecho forestal, estatal y autonómico), coordinados por Luis Calvo Sánchez, Edito-rial Aranzadi, Navarra, 1. ${ }^{\text {a }}$ ed., p. 494.

$\mathrm{Al}$ efecto, hemos de recordar que la Ley de Montes de 2003 integró en el dominio público, por obra de su artículo 12.1, a los montes catalogados, a los comunales y a los destinados a un uso o servicio público, respondiendo la anterior clasificación forestal de los montes públicos a la que distinguía entre montes catalogados y no catalogados, considerándose todos ellos como patrimoniales, clasificación ésta anterior a la que se unía la clasificación derivada de la legislación sobre bienes públicos y —especialmente - de la reguladora de los bienes municipales, dada la enorme importancia de las masas forestales de los municipios, mezclando ahora la Ley de Montes de 2003 ambas clasificaciones, integrando en el dominio público tanto los montes que lo merecen por motivos de interés forestal (los catalogados) como los montes cuya demanialidad - en realidad - derivaría de fundamentos no propiamente forestales, como ocurre con los montes comunales, respecto de los cuales sorprende su integración en el dominio público por la Ley de montes de 2003 «en tanto su aprovechamiento corresponda al común de los vecinos» (artículo 12.1.b), pues hoy la falta de su aprovechamiento común no determinaría directamente (como antaño) su desafectación (como parecería sugerir en principio la locución «en tanto»), amén de que difícilmente parece aplicable a los montes comunales el régimen de usos previsto con carácter general para el dominio público forestal por el artículo 15 de dicha ley, dado que su aprovechamiento y disfrute prioriza su explotación colectiva o caso de su imposibilidad- seguir la costumbre u ordenanza local.
} 


\section{EL PROBLEMA DE LA RENDICIÓN DE CUENTAS DE LAS ENTIDADES}

\section{LOCALES MENORES O LA AMENAZA FANTASMA DE SU DESAPARICIÓN.}

Que las ELM están obligadas a rendir cuentas todos los años antes del 31 de octubre del año siguiente al que se refieren, no es ninguna novedad ${ }^{326}$. Las ELM al tener la consideración de entidad local están sometidas a las mismas obligaciones y condicionantes en la rendición de sus cuentas que los municipios. Dicha exigencia ya se venía requiriendo en la Ley de Haciendas Locales del año 1988, y en el mismo sentido se dispone actualmente en el Texto Refundido de la Ley de Haciendas Locales del año 2004 (TRLHL). Pero, ¿de qué cuentas estamos hablando?. La Ley de Haciendas era y es muy clara, al afirmar que todas las entidades locales deben aprobar anualmente un Presupuesto que recoja tanto las obligaciones a reconocer como los ingresos a percibir y este mandato de confección y aprobación del documento más importante en la gestión de un ente local, pues de él dependen todas las acciones de la misma, se viene incumpliendo ampliamente por las ELM que no cuentan con una cultura de rendición desde el punto de vista formal $^{327}$, en algunos casos, y con medios adecuados, en otros, para disponer de dichas herramientas. Y ese Presupuesto una vez ejecutado dará lugar a la liquidación del mismo, y por tanto y según dispone el art. 193.5 TRLHL, a la obligación de envío de copia de la liquidación presupuestaria tanto a la Administración del Estado ${ }^{328}$ (actualmente al Ministerio de Hacienda y AAPP a través de la plataforma telemática conocida como

\footnotetext{
${ }^{326}$ MIRA-PERCEVAL PASTOR/CORTELL GINER "La rendición de las cuentas de las entidades locales y sus entes dependientes" Revista Auditoría Pública ${ }^{\circ}$ 40. 2006. Pp. 87-92, como señalan los autores no hay ninguna duda de que en este sentido el art. 223 TRLHL es suficientemente amplio ya que sujeta a control externo no sólo a las entidades locales sino a todos los organismos y sociedades de ellas dependientes, y por supuesto a las ELM.

${ }^{327}$ Muchas de ellas vienen rindiendo sus cuentas ante sus convecinos a su modo, es decir, prácticamente consiste en una presentación pública en la asamblea vecinal o incluso a disponer en los tablones de edictos de las mismas copias de los extractos bancarios, pero esa manera, tan llamémosla rudimentaria, de presentar unas cuentas públicas no se adapta a ninguna de las exigencias en cuanto a la forma y el fondo previstas en la normativa vigente.

${ }^{328}$ A través de la Orden EHA/468/2007 de 22 de febrero se establecieron las condiciones generales y el procedimiento para la presentación telemática de la liquidación de los presupuestos de las entidades locales y entre ellas las ELM, es decir, a partir de la entrada en vigor de esta Orden el Ministerio de Hacienda solo admite las liquidaciones presupuestarias rendidas a través de medios telemáticos. Además se exige que el firmante de los datos sea siempre el Interventor o funcionario asimilado de la entidad local, sin que pueda delegar su firma, lo cual genera el problema indicado de la persona adecuada para poder remitir dicha documentación por parte de las ELM.
} 
“Oficina Virtual de las Haciendas Locales") como a la Comunidad Autónoma correspondiente ${ }^{329}$.

Pero además hay que confeccionar la llamada Cuenta General ${ }^{330}$, expediente que pone de manifiesto la gestión realizada en los aspectos económico, financiero, patrimonial y presupuestario. Estos estados de cuentas hay que remitirlos, como hemos dicho, en nuestra Comunidad Autónoma, antes del 31 de octubre del año siguiente al ejercicio a que se refiere, al Consejo de Cuentas de Castilla y León, y desde el año $2007^{331}$ únicamente se admite dicha rendición por medios telemáticos, lo cual hace que el

\footnotetext{
329 Debemos recordar que en Castilla y León y después de la modificación estatutaria del año 2007 las competencias en materia de tutela financiera fueron asumidas por la CA (artículo 54 de la Ley Orgánica 14/2007).
}

${ }^{330}$ La Cuenta General es un "elemento clave" de la transparencia en las relaciones con los ciudadanos y constituye "el reflejo de la situación económico-financiera y patrimonial de las entidades locales y sus entes dependientes".

${ }^{331}$ Por Acuerdo 32/2007, de 19 de abril, el Pleno del Consejo de Cuentas de Castilla y León, en desarrollo de lo previsto en el artículo 19 del Reglamento de Organización y Funcionamiento del Consejo de Cuentas y en las reglas 104.3, 24 y 92 de las Instrucciones de Contabilidad Local de los modelos normal, básico y simplificado, respectivamente, reguló el formato de la Cuenta General de las Entidades Locales en soporte informático, estableciéndose de forma transitoria el procedimiento para su remisión mediante CD o DVD.

Asimismo, de acuerdo con lo aprobado por el Pleno del Consejo de Cuentas, el 24 de abril de 2007 se suscribió un Convenio de Colaboración con el Tribunal de Cuentas para la implantación de medidas de coordinación de la rendición telemática de las Cuentas Generales de las Entidades Locales, en virtud del cual las cuentas presentadas de conformidad con lo dispuesto en el citado Acuerdo 32/2007 se consideran rendidas por ambas Instituciones.

Posteriormente, mediante Acuerdo 73/2007, de 4 de octubre, se reguló el procedimiento para la remisión de la Cuenta General de las Entidades Locales por medios telemáticos, y se estableció, con carácter excepcional, un procedimiento alternativo.

Por otra parte, las modificaciones que en el régimen contable de las empresas se han producido, desde la aprobación del Acuerdo 32/2007, derivadas de la necesaria armonización internacional con base en la normativa de la Unión Europea, hicieron necesaria una adecuación de los formatos de la Cuenta General de las Entidades Locales establecidos en dicho Acuerdo.

Además, la propia experiencia en la aplicación de los citados Acuerdos, el continuo avance de las técnicas disponibles en el tratamiento de la información contable, la ejecución de diversos programas para la dotación de medios informáticos y telemáticos a las Entidades Locales, junto con una más intensa vinculación telemática de las diversas Instituciones de Control Externo, aconsejaron también introducir modificaciones en el procedimiento de remisión de las Cuentas Generales de las Entidades Locales regulado en el Acuerdo 73/2007, limitando la rendición de las mismas exclusivamente por medios telemáticos.

A la vista de lo anterior, se aprobó el Acuerdo 70/2009, de 23 de julio, del Pleno del Consejo de Cuentas de Castilla y León, por el que se regula el formato de la Cuenta General de las Entidades Locales en soporte informático y el procedimiento para su remisión por medios telemáticos, y con él se pretendió reunir en una sola norma la regulación del formato de la Cuenta General de las Entidades Locales en soporte informático y el procedimiento para su remisión por medios telemáticos, incorporando las modificaciones señaladas, estableciendo que las Cuentas Generales de todas las EELL serán rendidas directamente al Consejo de Cuentas de Castilla y León, de acuerdo con lo establecido en el artículo 8 de la Ley 2/2002, por los 
cumplimiento de esta obligación sea más dificultoso para las ELM, que en muchos casos ni cuentan con medios informáticos adecuados ni con conexiones telemáticas rápidas.

Pero para poder rendir adecuadamente las cuentas es necesario que se realice la preceptiva labor de control a través de la función interventora, y este aspecto se está olvidando, en el ámbito que nos ocupa, también por aquellos que tienen la capacidad de legislar y de exigir el cumplimiento del mismo. Parece que la función de intervención en estos casos es una mera apariencia de control, apenas sí se le da importancia, puesto que sólo se habla de que se rindan cuentas, de que se presenten, casi a efectos estadísticos podríamos decir, olvidando totalmente la necesidad de ese previo control interno. Y qué decir del control financiero y el control de eficiencia que también recoge la Ley de Haciendas desde hace más de veinte años, y que también debe estar presente en la gestión local.

Como vemos hoy en día apenas se realiza ninguna de estas exigencias, además en las ELM y entidades de pequeño tamaño los mismos funcionarios que gestionan la ejecución del presupuesto son los que lo elaboran ${ }^{332}$, y son a la vez los que han de fiscalizar la gestión. Esta situación esquizofrénica llega a ser casi imposible de desarrollar ${ }^{333}$, no quedando más que poder hablar de "apariencia de control" como ya hemos señalado. El funcionario que tiene la responsabilidad de controlar la actuación de los órganos de gobierno está solo. Los órganos de control externo se limitan a comprobar que se remiten las cuentas y que no contienen incoherencias, nada más, incluso ya ni se requieren los "reparos" de intervención ${ }^{334}$, es decir, aquellos informes sobre los acuerdos

cuentadantes responsables, en el modelo y formato normalizado recomendado por la Resolución de la Intervención General de la Administración del Estado de 28 de julio de 2006 («B.O.E.» 9 de agosto de 2006), y de esa manera y en virtud del Convenio suscrito entre el Consejo de cuentas de Castilla y León y el Tribunal de Cuentas de fecha 24 de abril de 2007 se entenderán remitidas de ese modo a ambas instituciones.

${ }^{332} \mathrm{Y}$ en los de gran tamaño donde los nombramientos habituales para proveer estas plazas son mediante el sistema de libre designación tan criticado por la doctrina, (véase MARTINEZ MARIN, A. "La reforma 2003 de los funcionarios con habilitación estatal" $R E A L n^{\circ} 291.2003$ ), hacen afirmar en no pocos casos que la libre designación pretende en realidad hacer desaparecer los controles internos de las grandes Administraciones Locales.

333 BIOSCA LOPEZ, F.J. "La apariencia de control en la administración por los habilitados estatales" Revista Auditoría Pública, $n^{\circ}$ 52. Año 2010. Pp. 71-78.

${ }^{334}$ Como es sabido el denominado "reparo" expresa un juicio contrario a la adopción de un acto o acuerdo por la Corporación Local, por estimarlos contrarios a la legalidad. Y no olvidemos que en determinados 
o resoluciones que se hayan adoptado en contra del Interventor ${ }^{335}$. Además los órganos de tutela financiera, por lo menos el que ejerce dicha competencia en Castilla y León, apenas desempeña una labor de apoyo, control y seguimiento para dar amparo a estas situaciones.

A todo esto se suma que la normativa de aplicación para la gestión contable y presupuestaria no es fácil de aplicar. Desde el mismo desarrollo y cumplimiento de las Instrucciones de Contabilidad ${ }^{336}$, que si bien se prevén tres sistemas de funcionamiento contable y a las ELM les podría corresponder el modelo "Básico", más sencillo y de registro por el método de partida simple y no doble, pero que en el fondo el contenido de las mismas es bastante similar al que se exige a los municipios, y añadiendo la verdadera dificultad que resulta de la aplicación y cumplimiento de la LOEP 2/2012 y la Orden 2105/2012, de 1 de octubre, por la que se desarrollan las obligaciones de suministro de información de la misma ${ }^{337}$, todas ellas a través únicamente por medios telemáticos y cálculos y previsiones que exceden de los simples "conocimientos numéricos". Y si bien en los últimos años se ha procedido a implantar medidas legales de refuerzo de control, recayendo en los FHN el grueso del trabajo, es muy difícil que se cumplan dichas exigencias en una ELM, por los problemas expuestos.

supuestos /art. 216 LRHL) el reparo puede incluso suspender la tramitación del respectico expediente. Véase LAZO VITORIA, X. "El estatuto de los funcionarios locales con habilitación estatal y algunas reflexiones en torno al control interno económico financiero en el ámbito local". Revista española de Derecho Administrativo, $n^{\circ}$ 141. 2009. Civitas. Madrid, y "El control sobre los entes locales tras la LRSAL. Rasgos fundamentales". Anuario de Derecho Municipal 2013. $N^{o}$ 7. Madrid. 2014. Pp. 71-92. La autora afirma con acierto que hay aspectos básicos relativos, por ejemplo, al procedimiento, a los plazos dentro de los cuales deben producirse estas actuaciones, al contenido del acto que resuelve en contra del criterio del órgano de control etc., que se encuentran huérfanas de toda mención por parte del legislador.

${ }^{335}$ BIOSCA LOPEZ, F.J. ob cit: "Los informes que pueden poner de manifiesto distintos incumplimientos de la normativa de aplicación no tienen efecto práctico, salvo en contadas ocasiones, de manera que se ven relegados a una función testimonial que conduce al desánimo, con la sensación de impotencia que genera comprobar que hasta depende del Alcalde dar cuenta al Pleno de los mismos. Y en otras, se deben emitir en un clima de tensión, cuando no media previa advertencia o toque de atención, que puede condicionar su contenido".

${ }^{336}$ Recientemente las mismas han sido objeto de nueva regulación, a través de las Órdenes HAP/1781/2013, de 20 de septiembre para el modelo Normal, la Orden HAP/1782/2013 para el modelo simplificado y la Orden EHA/4040/2004 para el modelo básico modificada por la Orden HAP/1782/2013.

${ }^{337}$ La LOEP exige llevar a cabo seguimientos, concretados en los cuatro informes anuales y otros cuatro trimestrales que se deben realizar conforme a la Orden HAP/2105/2012, estos informes en muchos casos los debe realizar el interventor, pero en otros supuestos no queda claro quién debe elaborarlos y ello puede crear problemas cuando los datos que se solicitan no son puramente técnicos, ya que en caso de no suministrar la información requerida o hacerlo de forma incorrecta no se establece quién es el responsable. 
Así las cosas son conceptos casi extraños y ajenos a las ELM medidas tales como el control y aplicación del objetivo de estabilidad presupuestaria y el seguimiento de los planes económico financieros en su caso ${ }^{338}$; el cumplimiento de suministrar información a la Base de Datos Nacional de Subvenciones por parte del Interventor; el análisis del cumplimiento de la regla de gasto; el control de la información trimestral sobre el cumplimiento del plazo de pago a proveedores (a raíz de la Ley 3/2004 de lucha contra la morosidad modificada por la Ley 15/2010), llevar el preceptivo registro de facturas etc...., por citar algunas de las más importantes obligaciones.

Nos encontramos, por tanto, con una situación en la que la amplia mayoría de las ELM no presentan ni rinden sus cuentas, al menos en la forma que legalmente se exige, y esta situación está dando lugar a muchas disfunciones, sobre todo a raíz de la tramitación y aprobación de la Ley 27/2013 de racionalización y sostenibilidad de la administración local, donde se establece, en su Disposición Adicional 4 ${ }^{\mathrm{a}}$, la medida de la desaparición de las ELM que no rindan sus cuentas ante los organismos correspondientes, como hemos visto en capítulos anteriores.

El primero borrador de anteproyecto de LRSAL hecho público en el mes de julio del año 2012 recogía la directa supresión de las ELM. Como hemos visto en el Capítulo relativo al desempeño del puesto de secretaría, este hecho hizo que se originaran movimientos de denuncia y protesta ante dicha situación, creándose plataformas de defensa (las Federaciones de Entidades Locales Menores) de las ELM, tanto a nivel provincial, regional y nacional. Las siguientes versiones de dicho borrador fueron matizando tal previsión y ya no se recogía la desaparición sin más de estas entidades, si no que se puso el acento en el hecho de la rendición de cuentas de las mismas, es decir, aquellas que no rindan las cuentas se verán avocadas a su supresión y se establecía un

\footnotetext{
${ }^{338}$ ESTEVE PARDO, ML. Ob cit. Pág. 171: “Cómo verificar el cumplimiento de todas las exigencias de la disciplina presupuestaria española, y cuál debe ser el órgano o los órganos encargadas del control de su aplicación. La primera observación que cabe hacer es que el pronunciamiento sobre el cumplimiento de la disciplina no puede ser absoluto, a la vista de los numerosos conceptos jurídicos indeterminados que se recogen-tales como déficit estructural o "tasa de referencia de crecimiento del PIB de medio plazo de la economía española"- y de la inseguridad jurídica que supone medir determinadas variables siguiendo la metodología del SEC-95, que sigue criterios diferentes a las normas presupuestarias y contables internas. Esta discrepancia supone que se tengan que practicar ajustes al resultado presupuestario, pero sin que ninguna norma jurídica precise hasta el momento cuáles deben ser estos ajustes".
} 
plazo de tres meses para cumplir con esa obligación ${ }^{339}$, plazo que finalmente en el texto de la LRSAL se ha fijado en una fecha concreta: el 31 de diciembre de 2014.

Pero la problemática no ha quedado ni mucho menos saldada, ya que sin estar regulado de una manera clara la forma de desempeño de los puestos de secretaríaintervención de estas entidades y la labor de llevanza de las cuentas, parece que la amenaza de su desaparición puede traducirse en una realidad. Mucho se ha dicho de la necesidad de que las instituciones provinciales y comarcales intensifiquen sus actuaciones en la prestación de servicios de cooperación y asistencia a municipios, "especialmente en las provincias con índices de rendición más bajos, con el fin de mejorar la gestión de la contabilidad y la rendición de la Cuenta General por parte de las entidades locales ${ }^{340,}$, con especial atención a las que tienen menos capacidad de gestión, como los ayuntamientos de pequeño tamaño y las entidades locales menores. Pero esta situación de incumplimiento en la rendición de las cuentas públicas no es nueva, como ya hemos dicho, si no que se vienen tolerando además por parte de las dos grandes administraciones con competencias en control externo, que son la Administración Central y la Autonómica, ya que nunca ha tenido consecuencias el incumplimiento reiterado por parte de estas entidades en sus obligaciones contables y sorprende que entidades públicas con recursos económicos públicos vivan y respiren sin ningún tipo de control financiero.

Los datos que presentamos a continuación mediante esta tabla arrojan un reflejo de cómo en nuestra Comunidad Autónoma se ha incrementado la labor y la respuesta por

\footnotetext{
${ }^{339}$ Pero ¿qué cuentas? ¿Las de qué año? Hemos realizado una consulta al Servicio Jurídico de la FEMP (en el mes de marzo de 2014) y esta ha sido la contestación ante esta imprecisión de la ley (intencionada o no, no queda claro): "La Disposición transitoria cuarta de la Ley de Racionalización y Sostenibilidad de la Administración Local establece en su apartado 2 que "Con fecha de 31 de diciembre de 2014, las entidades de ámbito territorial inferior al Municipio deberán presentar sus cuentas ante los organismos correspondientes del Estado y de la Comunidad Autónoma respectiva para no incurrir en causa de disolución". Como vemos esta disposición no hace referencia a las cuentas de un ejercicio concreto, por lo que las entidades de ámbito territorial inferior al municipio deberán presentar las cuentas que, a fecha 31 de diciembre de 2014, estén obligada a haber presentado. Además, el apartado 3 de esa misma disposición cuando tipifica como causa de disolución de las EATIMs "la no presentación de cuentas" lo hace con carácter general, sin circunscribir esa no presentación a uno o varios ejercicio concretos, por tanto habrá que entender que habrá que cumplir siempre la obligación de presentar las cuentas para no incurrir en causa de disolución". Si bien esta cuestión ha quedado resuelta por la reunión celebrada el 19 de septiembre de 2014 entre la Secretaria General de coordinación autonómica y local y la Federación de Concejos, Pedanías y Parroquias rurales donde se afirmó que el Gobierno solo exigirá la presentación de las cuentas del año 2013 y no la de años anteriores.
} medidas -para-cumplir-el-ciclo-presupuestario/1382433949 
parte de las ELM en la rendición de la Cuenta General, en los últimos años, abarcando el periodo 2007 a 2012. En dicha tarea ha sido fundamental e imprescindible el apoyo de las Diputaciones Provinciales a través de sus oficinas de Asistencia a Municipios.

\begin{tabular}{|c|c|c|c|c|c|c|c|c|c|}
\hline Anualidad & Ávila & Burgos & León & Palencia & Salamanca & Segovia & Soria & Valladolid & Zamora \\
\hline $\begin{array}{c}\text { Total } \\
\text { ELM/provincia }\end{array}$ & $\mathbf{2}$ & $\mathbf{6 5 1}$ & $\mathbf{1 2 3 2}$ & $\mathbf{2 2 6}$ & $\mathbf{1 9}$ & $\mathbf{1 7}$ & $\mathbf{5 6}$ & $\mathbf{9}$ & $\mathbf{1 4}$ \\
\hline $\mathbf{2 0 0 7}$ & 0 & 10 & 48 & 49 & 7 & 2 & 22 & 3 & 8 \\
\hline $\mathbf{2 0 0 8}$ & 0 & 46 & 56 & 17 & 8 & 2 & 21 & 3 & 8 \\
\hline $\mathbf{2 0 0 9}$ & 0 & 180 & 98 & 50 & 9 & 2 & 27 & 3 & 10 \\
\hline $\mathbf{2 0 1 0}$ & 0 & 250 & 291 & 51 & 9 & 3 & 29 & 4 & 10 \\
\hline $\mathbf{2 0 1 1}$ & 0 & 280 & 411 & 59 & 10 & 4 & 29 & 6 & 10 \\
\hline $\mathbf{2 0 1 2}$ & 2 & 343 & 723 & 91 & 9 & 9 & 28 & 6 & 9 \\
\hline $\begin{array}{c}\mathbf{2 0} \text { rendición } \\
\mathbf{2 0 1 2}\end{array}$ & $\mathbf{1 0 0}$ & $\mathbf{5 2 , 6 9}$ & $\mathbf{5 9 , 6 9}$ & $\mathbf{4 0 , 2 7}$ & $\mathbf{4 7 , 3 7}$ & $\mathbf{5 2 , 9 4}$ & $\mathbf{5 0 , 0 0}$ & $\mathbf{6 6 , 6 6}$ & $\mathbf{6 4 , 2 9}$ \\
\hline
\end{tabular}

Fuente: Web Consejo de Cuentas Castilla y León febrero 2014

En esta gráfica se puede observar mejor el incremento casi exponencial tan importante en el número de cuentas rendidas en los últimos años, sobre todo en las tres provincias con mayor número de ELM, que son: León, Burgos y Palencia.

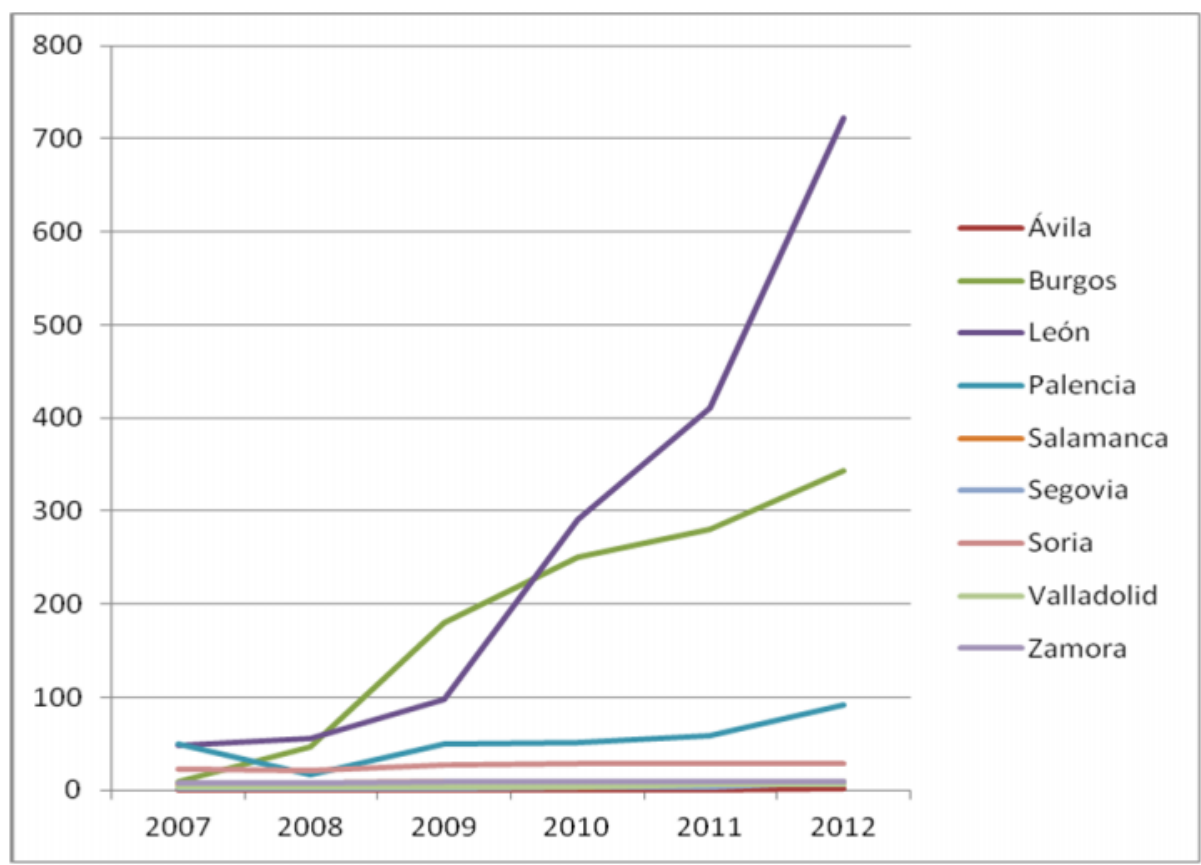

Fuente Consejo de Cuentas de Castilla y León. Febrero 2014. Elaboración propia.

La Comisión de Hacienda de las Cortes regionales ha recomendado a las EELL que adopten medidas para asegurar el cumplimiento del ciclo presupuestario conforme a la 
normativa, en particular el cumplimiento de los plazos establecidos desde la confección y aprobación del presupuesto del ejercicio hasta la rendición de la Cuenta General.

Pero quiero destacar que en el caso de las ELM se requiere además una actuación firme por parte de las instituciones competentes del ámbito territorial de nuestra Comunidad Autónoma, dirigida tanto a solventar los problemas de dichos entes relativos al efectivo registro contable de sus operaciones, como a la rendición de la Cuenta General en sí misma. No debemos olvidar que la rendición únicamente se puede realizar por medios telemáticos y que ya hemos recalcado que no todas las ELM disponen de recursos informáticos adecuados, si bien las Diputaciones Provinciales hacen una labor esencial en el apoyo a estas entidades llegando incluso en algunos casos a realizar ellas mismas la remisión telemática de esas cuentas, es necesario que se flexibilice no solo el sistema contable a exigir a una ELM si no también la forma de rendición de las mismas.

Así y de una manera un tanto tímida, la CA en Acuerdo de 22/2014' de 30 de enero de la Junta de Castilla y León por la que se aprueban las Medidas para la reforma de la Administración de la Comunidad de Castilla y León ${ }^{341}$, en su apartado I.A.Instituciones Propias y subapartado I.A.2. Flexibilización de presentación de cuentas de entidades locales menores, establece que teniendo en cuenta la realidad de estas entidades es necesario facilitar el camino a las mismas para que se produzca la rendición de cuentas. La medida consiste en "facilitar a las ELM el cumplimiento de la obligación de presentar a sus cuentas ante el Consejo de cuentas". El órgano impulsor de esta medida será la Consejería de Presidencia, pero no se explica en qué consistirá dicha ayuda ni dicha medida, si bien es un paso que se haya citado ya expresamente la realidad de este problema, no deja de ser una mera declaración de intenciones este Acuerdo de Medidas de reforma, pues como plazo de ejecución se había fijado en el mismo "antes de finalizar marzo de 2014" y habiendo llegado ese momento temporal nada se ha producido al respecto.

Todo este problema enlaza con la designación ${ }^{342}$ de la persona responsable de tales $\operatorname{cometidos}^{343}$, es decir, sobre la persona a proveer o desempeñar el puesto de secretaría de

\footnotetext{
${ }^{341}$ BOCYL de fecha 3 de febrero de 2014.

${ }^{342}$ La Resolución de la Comisión de Hacienda constata que las deficiencias contables de los entes de menor tamaño tales como las ELM derivan de sus insuficiencias organizativas, que demandan de los propios entes locales una mayor dotación de recursos humanos adscritos a funciones contables.
} 
las ELM. Y lo no se puede seguir manteniendo o esgrimiendo como excusa para mantenerse en esa situación de incumplimiento en muchos de los casos, es que se carece de medios ${ }^{344}$, pues quizás hemos llegado ahora ante este contexto de replanteamiento de las propias instituciones y de la existencia de entes como estas que constituyen un cuarto nivel de descentralización en nuestro país ${ }^{345}$, al momento determinante de pensar ¿tienen estas entidades madurez suficiente para seguir existiendo?. Lo que no es de recibo es que una entidad pública con unos recursos económicos en un porcentaje más superior que los que disponen muchos ayuntamientos, aleguen que no disponen de medios adecuados para proceder a fiscalizar y rendir las cuentas. Que no dispongan de equipos informáticos parece impensable hoy en día, pero es una realidad.

Lo que tiene que facilitar el ordenamiento jurídico es cierta flexibilización a la hora de la designación de la persona responsable en realizar dichas funciones de $\operatorname{control}^{346}$, fiscalización y llevanza de la contabilidad, sin que, ni sea tan laxo como se ha

\begin{abstract}
343. La modificación operada de la regulación contenida en el EBEP por la que se cambio a que la regulación del régimen jurídico del colectivo de los FHE fuera autonómica fue criticada por la doctrina, véase SOSA WAGNER, F. "Nuevo desalojo del Estado: secretarios a interventores" El Mundo; y de hecho la CA de Castilla y León no respondido como podría desearse y empleando las armas y medios que ha tenido a su alcance para poder corregir o regular esta situación de laguna o vacío en la regulación de los puestos de secretaría en las ELM y cuando lo ha realizado véase CAPITULO lo ha hecho mal y con una manifiesta intención de desidia.
\end{abstract}

${ }^{344}$ Haciendo un análisis de los presupuestos aprobados por las ELM de la provincia de Palencia en los dos últimos años hemos detectado que la media de los importes de los presupuestos de las mismas se halla en 25.000 euros, y que existen numerosísimas ELM con presupuestos que alcanzan las cifras de 80.000 euros anuales, más incluso que los municipios a los que pertenecen.

${ }^{345}$ BIOSCA LOPEZ, F.J. "La apariencia de control en la administración local por los habilitados estatales". Rev. Auditoría Pública $n^{\circ}$ 52. 2010. Pp. 71-78: "A la vista de la evolución de la normativa presupuestaria y de control aplicable a las entidades locales, por la propia falta de desarrollo de aspectos fundamentales y ante las dificultades para el ejercicio de control, es necesario realizar una reflexión sobre la realidad con la que conviven los habilitados estatales, para llegar a la conclusión de que en la actualidad no existe el control sobre la actuación de la Administración Local que demanda la sociedad ante la situación de crisis económica: control del déficit público y optimización de los recursos".

${ }^{346}$ FERRAN DILLA/CABELLO RODRIGUEZ. "La externalización del control económico financiero en el ámbito local a la luz de la reciente Informe de fiscalización del Tribunal de Cuentas" Revista Española de Control Externo $n^{\circ} 33.2009$. Pp. 39 a 64. En este artículo los autores desgranan un Informe del TCu en el que: "La posición que se mantiene en el Informe es la estricta defensa de las competencias atribuidas a los funcionarios de Administración Local con habilitación estatal por una norma estatal que resulta reguladora de la estructura y organización administrativa de las entidades locales.

Esa posición es no solo fruto de una mera interpretación restrictiva de la legalidad vigente -la Ley 7/1985, de 2 de abril, Reguladora de las Bases del Régimen Local (LRBRL), y Real Decreto legislativo

781/1986, de 18 de abril, Texto Refundido de disposiciones vigentes en materia de régimen local (TRLRL) - respecto de lo que constituye el ejercicio de las funciones propias del control interno como función pública, resultado de una coherente y estricta sujeción a la literalidad del texto legal estatal; también de la organización administrativa que de ese texto legal se desprende, con la consiguiente defensa de la 
llegado a decir que "cualquier vecino con ciertos conocimientos de números puede llevarlas", lo cual muestra un absoluto desconocimiento de la labor contable e interventora local, máxime cuando hoy en día todo está orquestado al ritmo que marca la Ley Orgánica de Estabilidad Presupuestaria 2/2012, así que ¿qué vecino y qué conocimientos tiene que tener para poder aplicar y calcular la regla de gasto, el análisis del cumplimiento de la estabilidad presupuestaria, el análisis del superávit presupuestario, el periodo medio de pago a proveedores para cumplir con la ley de morosidad etc....?; ni se pierden o desdibujen las funciones reservadas al Cuerpo de FHN. Y todo esto con remisiones trimestrales telemáticas de la información de ejecución presupuestaria al Ministerio de Hacienda, ¿no se necesitará más a una persona especializada y profesionalizada? O si no cambiar el sistema y flexibilizar o reducir dichas exigencias a unos entes con una gestión presupuestaria más simple y con unas competencias más sencillas y sin apenas servicios públicos que prestar?.

La "Moción del Tribunal de Cuentas aprobada el 30 de marzo de 2003" por su Pleno y relativa a las posibles soluciones legales y administrativas para que entidades locales rindan sus cuentas de forma completa y en los plazos legalmente establecidos, tras referir que el ejercicio de las funciones de control, de acuerdo con lo establecido en el artículo 92.3 de la LRBRL, estaban reservadas a funcionarios con habilitación nacional, ya avanzaba en aquel momento que la existencia de puestos de trabajo específicos, reservados a un colectivo de funcionarios seleccionados por la Administración del Estado, no pueden atribuirse a otros funcionarios de la Corporación distintos a los de habilitación nacional y debería garantizarse su adecuado ejercicio.

Sin embargo, reseñaba una serie de factores que dificultaban y desvirtuaban, ya entonces, el ejercicio de estas funciones en la Administración local, y que paso a enumerar, por lo acertado de las mismas:

- El elevado número de vacantes existentes en los puestos reservados a estos funcionarios origina que, en su mayor parte, estén cubiertos en régimen de interinidad o accidentalidad $^{347}$.

condición de función pública del control interno en el ámbito local; de las atribuciones funcionales realizadas por la legislación estatal respecto del régimen local a favor de determinados cuerpos, los de habilitación estatal - los denominados de habilitación nacional en la redacción original de la ley-, y de la concreta exigencia que de unas normas tan precisas se derivan".

${ }^{347}$ Lo cual es muy criticable, que no se aprueben las OEP necesarias para cubrir y dotas esas vacantes de un Cuerpo de funcionarios profesionalizados, y que por parte de la JCYL que tienen encomendada la función 
- En numerosos municipios, especialmente los de menor dimensión, además de las funciones reservadas se les encomendaban otras que, por vinculadas a la gestión, contrariaban los principios de control. Es habitual que los secretarios-interventores realicen funciones de todo tipo y categoría, al carecer estos municipios de personal administrativo.

- El ejercicio de la función de control y fiscalización interna no está suficientemente desarrollado en las entidades locales ${ }^{348}$, señalaba la Moción, en contraposición a la del Estado, que se presenta concebida como un instrumento para el perfeccionamiento de la actividad controlada, caracterizado por la plena autonomía. Pese a la regulación que ofrece la Ley de Haciendas Locales y el Real Decreto 1174/1987, de 18 de septiembre, sobre el Régimen Jurídico de Funcionarios de la Administración Local, la regulación de la función interventora en el ámbito del subsector local es considerada insuficiente, debiendo ser objeto de un desarrollo reglamentario que delimitara aspectos relevantes, como ámbito de aplicación, formas de ejercicio, medidas a adoptar en caso de omisión, cauce a seguir por los informes que se emiten, etc.

La "Nota aprobada por el Pleno de 28 de febrero de 2006 del TCu", sobre las causas de no rendición de las cuentas correspondientes a los ejercicios 1997-2001 mencionaba, como una de las causas más importantes de esta irregularidad la falta de recursos humanos y problemas de formación o capacitación del personal administrativo del área contable y del personal de Intervención. Además del intrusismo muchas veces traducido en la llevanza de la contabilidad pública en estas entidades a través de gestorías privadas u otros medios, y produciéndose en muchos casos la falsa creencia de que sí estaban confeccionadas dichas cuentas y cumpliendo de este modo con la obligación de la rendición, y no ha sido así. Ya hemos indicado que la rendición en papel no es válida ni aceptada por el Consejo de Cuentas, ni muchos de los formatos informáticos que utilizan

\footnotetext{
de control de legalidad en los nombramientos inadecuados de estas EELL no se realice dicho control con una mayor exhaustividad. Si bien y muy recientemente hemos acudido a ver la publicación en el BOE de una Oferta de Empleo Público extraordinaria (5 de abril de 2014) de plazas de interventores del cuerpo de FHN precisamente motivada en el cumplimiento de la LOEP, del incremento de las funciones de control y de fiscalización en las EELL sobre todo ante el gran número de vacantes existentes en nuestras EELL.

${ }^{348}$ LAZO VITORIA, X. ob cit. Véase: el control interno del gasto público local [...] es criticable que pese al tiempo transcurrido desde la aprobación del LRHL aun no se haya procedido a un adecuado desarrollo reglamentario de esta materia, ya que el último es del año 1990 (Real Decreto 500/1990).
} 
estas empresas privadas están homologados, ya que el órgano de control externo ha dispuesto de unos formatos aprobados y normalizados, como hemos referido ${ }^{349}$.

Ante estas situaciones, la "Federación Leonesa de ELM", por citar un ejemplo, ha comprobado que muchos Alcaldes pedáneos que creen que han rendido adecuadamente cuentas, en realidad no lo han hecho o, al menos no figuran sus datos en el Ministerio de Hacienda ${ }^{350}$; por ello, la Federación está realizando una campaña informativa a todos las Juntas Vecinales para que comprueben cuáles son las cuentas que realmente figuran en los archivos del Ministerio de Hacienda, "pues si sus cuentas no están allí, serán suprimidas". Y eso será ya objeto de otra historia, es decir, ver si la CA iniciará expedientes de supresión de ELM cuando éstas no procedan a rendir sus cuentas en el plazo indicado por la LRSAL.

Como último punto me gustaría exponer las actuaciones llevadas a cabo por el órgano de control externo de Castilla y León, el Consejo de Cuentas, ante esta tesitura, y así las cosas dicho órgano fiscalizador recibió en el mes de marzo de 2014 un encargo por parte de las Cortes de Castilla y León de garantía de la pervivencia de las ELM, y le encomiendan el seguimiento de las mismas, aprobando una enmienda para que el Consejo de Cuentas se implique en el desarrollo de una colaboración expresa con las ELM, incluyendo este objetivo como capital dentro del Plan Anual de Fiscalización del Consejo para el año 2014. Este objetivo se ha traducido en un esfuerzo en reforzar ${ }^{351}$ la concienciación en la obligación legal de rendir cuentas, concretándose las iniciativas al respecto en dos líneas de trabajo: el Consejo habilitó en su página web un apartado especial de información específica; y por otra parte se trabajó en la coordinación tanto con la Junta de Castilla y León (en este caso mediante la firma de protocolos por la CA con las tres Diputaciones Provinciales más afectadas, León, Palencia y Burgos, de ayudas con cargo al Fondo de Cooperación Territorial destinadas a incrementar la ayuda en la asistencia contable y presupuestaria de las ELM), la realización de unas auditorías por muestreo y obtención de información respecto de ELM de estas tres provincias y por último una ronda de intervenciones divulgativas en colaboración con las tres instituciones

\footnotetext{
${ }^{349}$ Acuerdo 73/2009 del Pleno del Consejo de Cuentas.

${ }^{350} \mathrm{http}: / /$ concejos.org/rendicion-de-cuentas-de-las-elm/

${ }^{351}$ Nota de prensa del Consejo de Cuentas de Castilla y León de 31 de marzo de 2014.
} 
provinciales citadas, dirigidas a las ELM para fomentar dicha concienciación. La labor incansable de las tres Diputaciones Provinciales en el apoyo y asistencia a estas ELM para la confección y presentación de las cuentas anuales, está arrojando estos datos cada vez más positivos:

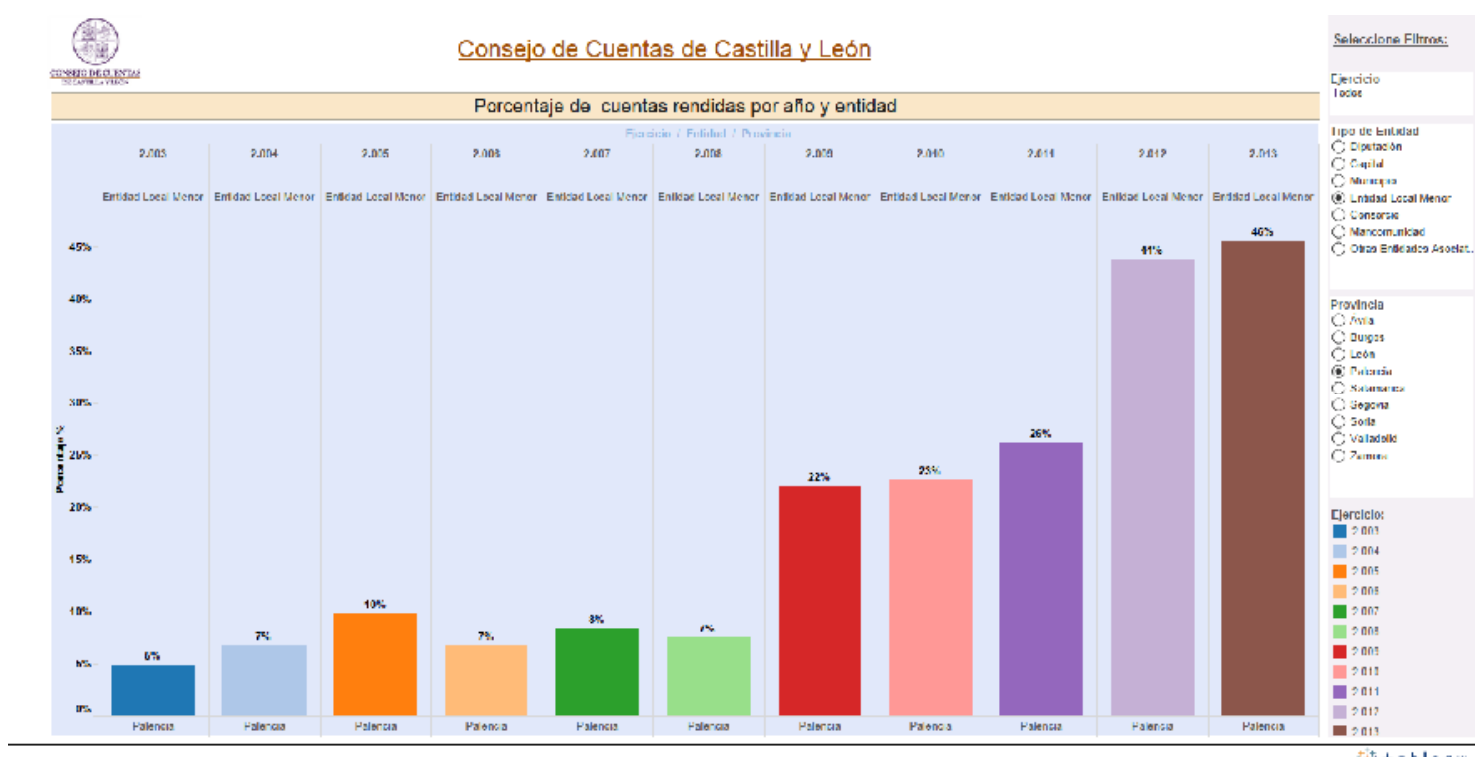

Palencia.

Fuente: Consejo de cuentas de Castilla y León. 19 de octubre de 2014.

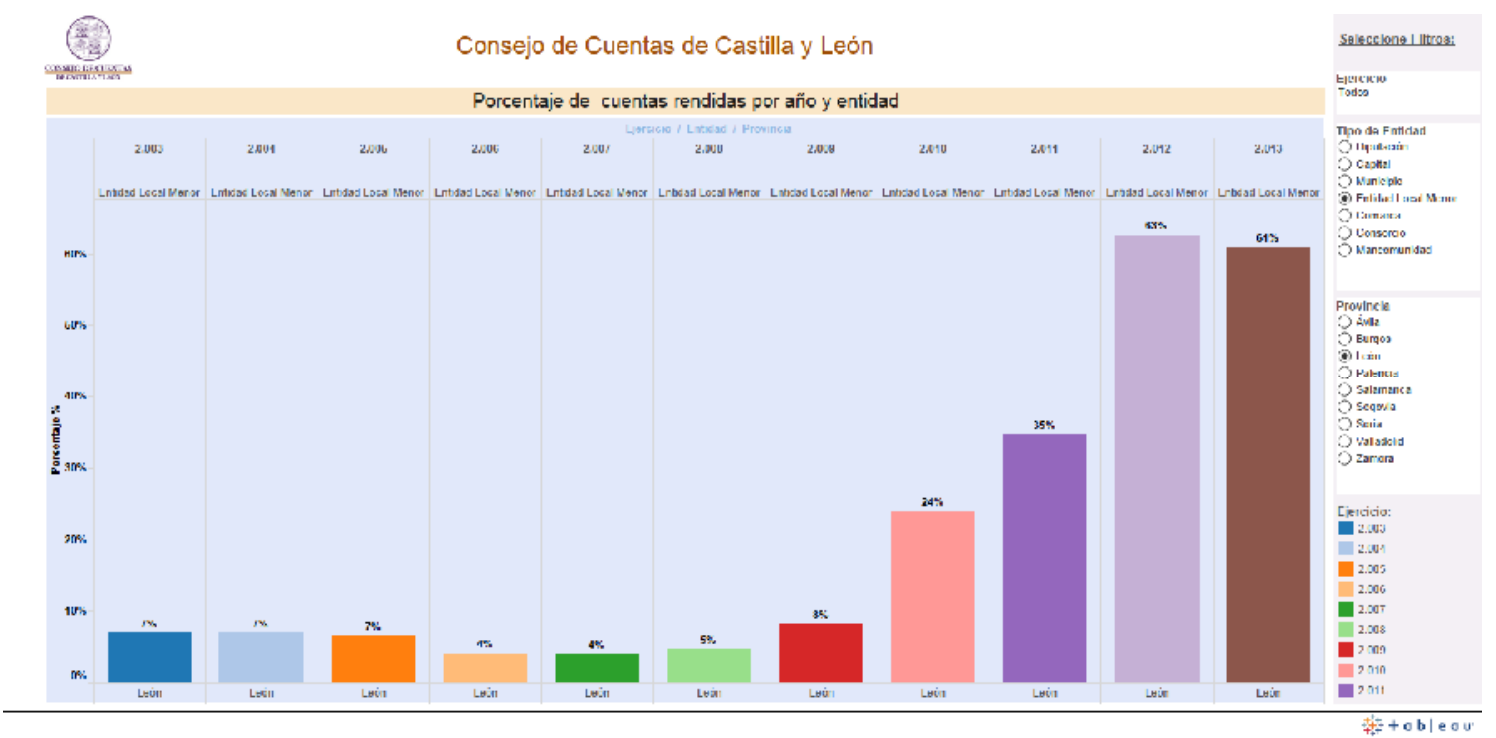

León.

Fuente: Consejo de cuentas de Castilla y León. 19 de octubre de 2014. 


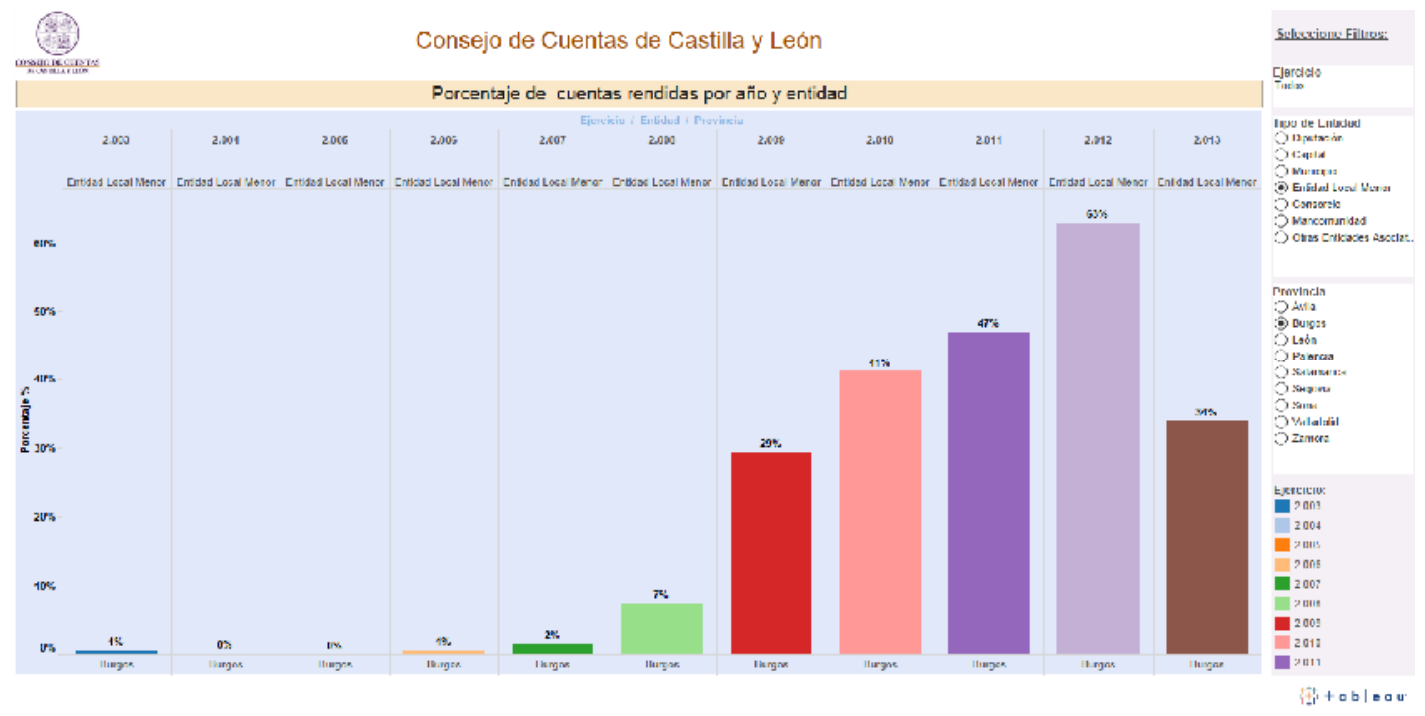

Burgos.

Fuente: Consejo de cuentas de Castilla y León. 19 de octubre de 2014.

Ante esta situación y a modo de cierre de este capítulo, y después de analizado los documentos expuestos, me gustaría establecer algunas propuestas respecto del problema tratado:

- Es necesario y fundamental simplificar la gestión contable en estas ELM, de menor capacidad y con muy pocas competencias asignadas ${ }^{352}$.

- Facilitar la rendición de cuentas de manera más sencilla, estableciendo alguna consecuencia ante la falta de la misma ${ }^{353}$.

\footnotetext{
${ }^{352}$ Véase Acuerdo de la Asamblea del COSITAL de Castilla y León de 21 de abril de 2012 en su punto tercero: "La extensión de ese criterio de flexibilidad a otros aspectos adjetivos relacionados con la administración de las Entidades Locales Menores, abogando por la simplificación de su actividad administrativa, de suerte que la misma se acompase al nivel de competencias que tengan atribuidas".

353 La LRSAL establece en su Disposición Final tercera que modifica la Ley 2/2011 de Economía Sostenible, al establecer que "en el supuesto de que las Entidades Locales incumplan la obligación de remitir al Tribunal de Cuentas la información a la que se refiere el artículo 212.5 TRLHL, se podrá retener el importe de las entregas a cuenta y, en su caso, anticipos y liquidaciones definitivas de la participación en los tributos del Estado que les corresponda, y hasta que se considere cumplida tal obligación de remisión. Para que la anterior retención, o suspensión de la misma, se pueda practicar será necesaria una comunicación del Tribunal de Cuentas a la Secretaría General de Coordinación Autonómica y Local”, si bien a las ELM esta medida no les afectaría. No obstante se puede establecer, como ya se ha hecho en alguna convocatoria de subvenciones, que se exija en las mismas como requisitos a cumplir por las ELM, tanto la presentación de la rendición de cuentas como la remisión del resto de la información que se solicite por el órgano de tutela financiera, sería adecuado que tal medida la permitiera exigir una norma con rango legal para poder plasmarlo luego en las convocatorias y/o bases reguladoras de subvenciones que se aprueben y cuyos destinatarios o posibles beneficiarios sean las ELM.
} 
- Establecer la fiscalización de un ente externo con un cuerpo jerarquizado con criterios comunes

- Exigir responsabilidades en aquellos supuestos, por ejemplo, de reconocimientos extrajudiciales de crédito desorbitados (ya que los mismos consisten en haber gastado en el ejercicio anterior sin crédito), pues resulta extraño que esta práctica a veces peligrosa no tenga cobertura de rango legal sino reglamentario a través del Real Decreto 500/1990, y que tengan efectos los informes de control para acabar con la sensación de impunidad de que nunca pasa nada ${ }^{354}$.

No puede olvidarse el interés del Estado o casi tendríamos que hablar de la responsabilidad del mismo, en el control financiero de las EELL ni que, como señalan DILLA y CABELLO ${ }^{355}$ que la organización de los EELL ha venido instituida mediante un sistema dirigido a evitar que funciones o competencias deban ser abandonadas por carencia de medios personales o materiales con los que hacer frente. El Tribunal de Cuentas recomienda en estos casos de disfunciones acudir a las administraciones asistenciales, es decir, a las Diputaciones Provinciales, cuando las entidades de menor tamaño perciban la inexistencia de capacidad con la que hacer frente a alguna de esas funciones, en especial las que se encuentran encomendadas a un determinado Cuerpo de Funcionarios como hemos visto. Por ello tal vez debiera repensarse la capacidad de las propias instituciones provinciales para poder prestar o incrementar la asistencia técnica que tienen encomendada y sobre todo los medios que a ella se destinan para dar cumplimiento a todas estas necesidades, pues si bien es verdad, es conocido que estas instituciones emplean recursos en la gestión de competencias "impropias", y no se debe olvidar la esencia misma de la función asistencial de estas instituciones que impone un obligación de colaboración dirigida a evitar el abandono o dejación de funciones por falta de medios.

Para poder superar este problema y pese a los altos niveles de rendición que se están consiguiendo en esta anualidad, la solución pasaría, a mí entender, por estos dos pasos fundamentales:

\footnotetext{
${ }^{354}$ BIOSCA LOPEZ, ob cit.

${ }^{355} \mathrm{Ob}$ cit.
} 
- Una regulación normativa de un régimen más sencillo y flexible de exigencia de la gestión presupuestaria y contable hacia estas entidades (a nivel estatal), acompañada de un régimen jurídico propio, éste regulado a nivel autonómico, de simplificación y racionalización en cuanto a la organización y funcionamiento de las mismas, así como una simplificación y por qué no, una eliminación de las obligaciones de remisión derivadas de la Ley Orgánica de Estabilidad Presupuestaria hacia las entidades menores: eliminación para ellas de la necesidad de comunicación de los informes trimestrales de ejecución, regla de gasto y estabilidad, eliminación de las informaciones trimestrales del periodo medio de pago etc.... Al igual que se ha aprobado recientemente la Orden HAP/2082/2014, de 7 de noviembre (BOE 8 de noviembre de 1014) donde se simplifica la obligación de suministros de información trimestral para los municipios con población no superior a 5.000 habitantes, se podría bajar a un nivel de mayor simplificación para las ELM.

- Una regulación normativa, de una vez por todas, relativa a las funciones reservadas de intervención y llevanza de la fiscalización y contabilidad (enlazado con las conclusiones vistas en el capítulo anterior). 


\section{VI.- CONCLUSIONES FINALES Y PROPUESTAS}

Expuestos tanto el origen y evolución de estas entidades así como la estructura legal de las mismas y su delicada situación actual, y examinadas las diversas anomalías que afectan a su organización y funciones, expondré las conclusiones y propuestas de mejora a los problemas detectados y analizados en la presente tesis, relacionados con la cuestión principal que sobrevuela todo el trabajo, que es ¿deben seguir existiendo las entidades locales menores?.

\section{I.}

La escasa atención doctrinal hacia estas entidades no se corresponde con su vigoroso desarrollo en el territorio español y más concretamente en la comunidad autónoma de Castilla y León, donde se ha visto que se integran más del $75 \%$ de las totales existentes, hecho que justifica su afianzamiento y arraigo como forma de organización local adecuada para los núcleos de población diferenciados del propio municipio del que dependen y en el que se integran.

En Castilla y León las comunidades vecinales que conforman los pueblos de la comunidad autónoma existen con fuerza y es su deseo el protagonizar los problemas públicos de sus núcleos. Sienten que aquello es algo suyo, exclusivo y donde ellos sólo pueden actuar, y a causa de este mismo sentir es por lo que funcionan mal. Se ha detectado que estas entidades no se ajustan a la normativa administrativa, invaden competencias municipales..., es decir, hasta ahora han actuado careciendo de fiscalización, actuando al margen del derecho, y consintiéndose dichas situaciones por las administraciones que tienen atribuidas las competencias de control, sobre todo se ha llegado a situaciones esperpénticas en cuanto al tratamiento y rendición de las cuentas públicas.

Los pueblos castellanos leoneses tienen conciencia de su propia identidad social y política y no sería bueno que se prescindiera de ella, sobre todo desde el punto de vista del principio democrático. 
Apoyar la tesis de la existencia y mantenimiento de estas entidades no lo puede ser a cualquier precio, hay que introducir unas reformas profundas en la regulación del régimen jurídico de estos entes. Como hemos visto, la actual regulación estatal deja a las ELM carentes de personalidad jurídica, pero, ¿qué ocurre con las ELM existentes hasta ahora, que son la totalidad de las mismas?, ¿van a pervivir con esa insuficiente regulación jurídica?.

Las reformas que propongo para atajar estos problemas, son, sistematizándolas por categorías o materias, las siguientes:

\section{Desde el punto de vista orgánico:}

$\checkmark$ Establecer un sistema de votación nominal y directo de los vecinos a todos los componentes de la Junta Vecinal, no únicamente el Alcalde Pedáneo;

$\checkmark$ Incrementar los mecanismos de participación de las ELM en las corporaciones municipales;

$\checkmark$ Respecto del régimen electoral previsto para las ELM, que se incluya como causa directa de disolución el supuesto de que una vez celebradas elecciones no se presentara nadie; y que el expediente se inicie de oficio por parte de las Diputaciones Provinciales a propuesta de la Subdelegación del Gobierno, sin necesidad de recurrir a la constitución de Comisiones Gestoras, las cuales, una vez formadas, han demostrado su ineficacia.

$\checkmark$ Establecer una fecha fija y determinada para la constitución de las ELM, y no dejarlo al criterio de la Junta Electoral de Zona.

$\checkmark$ Respecto del problema de la coincidencia en la existencia de una ELM con el propio municipio éste no ha sido regulado de manera tajante, siendo en la actualidad muy numerosos los casos en los que se superponen ambas figuras y ante esta tesitura no se ha hecho nada por corregirlo. Por tradición venían siendo compatibles e incluso existían supuestos de división del término en micromunicipios independientes entre sí, pero aglutinados por la presencia del Ayuntamiento superpuesto, compartiendo presencia física sin interferencias en los cometidos de cada entidad. Debería 
resolverse por ley este problema, suprimiendo directamente la existencia de ELM donde radique el Ayuntamiento.

Desde el punto de vista competencial:

$\checkmark$ Modificar la normativa autonómica en el aspecto relacionado con el ejercicio de competencias delegadas por parte de la ELM, indicando que aquellas competencias que se están llevando desde hace años de forma delegada tácitamente por parte de las mismas (existen amplios problemas en relación al desempeño de las competencias de abastecimiento de agua y alumbrado público), se estableciera expresamente que el desempeño de aquellas les puede corresponder a las ELM, pero entendiendo que actuarían bajo la dirección técnica y jurídica del municipio, que sería el que previamente habría de definir la forma de prestación de los servicios, las tarifas, ordenanzas..., en forma similar a como se prevé en la LRSAL para los municipios respecto de las Diputaciones, apostando por una coordinación municipal de servicios.

$\checkmark$ En la misma línea de actuación, asignar a los municipios las facultades de creación e implantación de obras y servicios, y que correspondiera a las ELM las competencias de administración y conservación de los mismos, dejando en manos municipales la organización, régimen de ordenanzas, y directrices para la ejecución de dichos servicios. En mi opinión es importante aprovechar la parte positiva del régimen jurídico de las entidades menores para perpetuarlo, acotando bien el campo competencial del municipio. Así se evitaría que fueran las ELM las que ejecutaran obras o implantasen servicios de ámbito municipal, estableciendo como alternativa el fortalecimiento de las funciones del municipio lo cual conllevará que el acceso de todos los vecinos a los mismos servicios se haga de un modo homogéneo.

La forma o vía de llevar a cabo estas modificaciones sería, en mi opinión, y siguiendo la opción desarrollada por otras CCAA, mediante la aprobación de una Ley autonómica reguladora del régimen específico de las ELM existentes ya que, y según el art. 24 bis de la LRSAL, estamos ante materia de competencia autonómica, y apoyándonos además como argumento, en que la regulación prevista en la Disposición Transitoria $4^{\mathrm{a}}$ de la 
LRSAL deja un vacío legal en cuanto a la regulación de las ELM existentes a la entrada en vigor de la misma (al haberse suprimido el art. 45 LRBRL).

Otra opción puede ser proceder a un desarrollo reglamentario según dispone la Disposición Final $8^{\mathrm{a}}$ de la LORSEGO, dando cumplimiento a lo recogido en la misma, cuando dice que se regulará y garantizará el mantenimiento de las actuales entidades locales menores, fomentando su modernización, y que en el marco de la legislación básica del Estado, reglamentariamente se determinaran las especialidades que puedan corresponder en el régimen de tesorería, contabilidad y fiscalización respecto a determinadas entidades locales menores, en función de su tamaño o presupuesto.

III.

Con relación a los problemas relativos a la gestión del patrimonio y bienes de las ELM: uno de los puntos polémicos que he detectado en el estudio del origen y evolución histórica de estas entidades es el referido a su posible disolución y cuál sería el destino de los bienes de la entidad suprimida, y de cómo ya en el año 1959 se estableció por la jurisprudencia de la época que en tal caso los bienes de la entidad disuelta pasarían a formar parte del patrimonio del municipio al que pertenecieran, salvo que dichos bienes fueran comunales, en cuyo caso podrían seguir disfrutándolo quienes lo hacían antes. Esta premisa es realmente importante de cara a la situación que vivimos en la actualidad causada por la amenaza de desaparición de las ELM, puesto que su valor más preciado es precisamente éste, la gestión patrimonial, y si por esta vía se pudiera garantizar que pese a la supresión de una ELM sus bienes van a poder seguir siendo aprovechados por las personas que residan en el núcleo suprimido como entidad local, eliminaría suspicacias.

Con relación al concreto tratamiento de los bienes comunales de las ELM: regular como supuesto de control por parte de los municipios, no solo aquellos referidos a la disposición de los bienes, sino también los que se refieran a la explotación de los mismos (supuestos de arrendamientos, cesiones de uso...); como medida complementaria o alternativa se podría desarrollar reglamentariamente la creación y regulación de las "oficinas provinciales" a las que se refería la Ley 1/1998, estableciendo unos controles de todo tipo de expedientes de explotación de los bienes, para homogeneizar los criterios a 
seguir en toda la comunidad autónoma, facilitando a dichas entidades modelos de pliegos, de ordenanzas etc...; si bien y desde mi punto de vista, creo que el ejercicio de la potestad reglamentaria sería más recomendable que se residenciara en el municipio.

IV.

Con relación al problema del desempeño del puesto de trabajo de la secretaría de las ELM: La LRSAL no ha procedido a dar más luz ni a perfilar el tema del régimen de las funciones de secretaría en las ELM y habrá que ver si el Estado, a través del Ministerio y del desarrollo reglamentario que debe hacer del régimen jurídico del cuerpo de habilitados nacionales, afronta de una manera más clara e indubitada la situación y regulación del desempeño de las funciones de secretaría e intervención en las entidades locales menores. Mientras llega ese momento la "Nota interpretativa del MINHAP de 5 de marzo de 2014 a la LRSAL" ha señalado que mientras no se produzca el desarrollo reglamentario del régimen jurídico de los FHN mantiene su vigencia, según dispone la Disposición Transitoria $7^{\mathrm{a}}$ de la LRSAL, la regulación vigente hasta el momento, en lo que no se oponga a la LRSAL.

En mi opinión la opción elegida por la comunidad autonómica de, finalmente, no sólo anular la regulación específica de esta materia mediante la derogación del Decreto 33/2013 (norma reglamentaria por la que llevábamos esperando 15 años), sino que la forma de acabar con el problema derogando a su vez la Disposición Adicional $6^{\mathrm{a}}$ de la Ley 1/1998, omitiendo con ello cualquier mención en la normativa autonómica a la forma del desempeño de los puestos de secretaría, provoca la imperiosa necesidad de que la Junta de Castilla y León asumiera este problema como suyo y ejercitara las competencias normativas adecuadas. No es plausible en aras del principio de seguridad jurídica, admitir prácticas legislativas tan poco afortunadas que implican la desaparición de una norma con tan solo dos meses de recorrido, derogándose incluso antes de entrar en vigor.

La situación ideal pasaría desde mi punto de vista:

Por una regulación actualizada por parte del Gobierno Central, ya que en este momento, como hemos dicho, se está tramitando la normativa reglamentaria de desarrollo del régimen de la habilitación nacional que no deje lagunas en este campo; 
$\checkmark$ Un desarrollo normativo más preciso por parte de la Comunidad Autónoma donde se permita, al igual que en otras CCAA, la figura de la agrupación de ELM para el sostenimiento en común del puesto de secretario, clasificándolo como puesto independiente de nueva creación (actualmente no se contempla en Castilla y León esta opción que sería, desde mi opinión, la que podría poner solución definitiva a esta situación), así no solo se consigue para el colectivo de FHN la creación de más puestos de trabajo, si no que fundamentalmente, se garantiza el desempeño de dichas funciones por personas cualificadas y preparadas con la habilitación legal necesaria.

$\checkmark$ Como opción residual aunque no la comparto del todo, podría establecerse la obligatoriedad de, superando un número de ELM en una provincia, creación de una oficina específica de desempeño de las funciones inherentes a la secretaría de estas ELM en las Diputaciones Provinciales, acompañado imprescindiblemente de la creación de los puestos de trabajo necesarios al efecto, tanto de personal FHN como de personal de apoyo. Pero como he dicho esta solución me produce cierto rechazo puesto que con ella se crearía una situación de discriminación respecto de los pequeños municipios, los cuales, con una población en muchos casos inferior a la que puedan tener algunas de las ELM, no recibirían este servicio por parte de las instituciones provinciales.

$\checkmark$ Por último, no permitir el desempeño de estas funciones a través de la figura del vecino habilitado o persona con capacidad suficiente. El puesto debe ser predefinido y retribuido y las funciones reservadas. La norma que recoge la figura de la persona capacitada es ya del año 1994, en estos momentos está superada por los tiempos y normativas actuales. Los estudios sobre estabilidad presupuestaria, análisis del cumplimiento de la regla de gasto, periodo medio de pago a proveedores, índices de morosidad, contabilidad analítica y de gestión de costes etc... derivados de la aplicación de la LOEP y sus desarrollos normativos exceden de la capacidad que pueda tener un "vecino". Son funciones profesionalizadas consecuentes con un control profesionalizado. 


\section{V.}

Con relación a la problemática sobre la preceptiva rendición de cuentas: Para poder superar este problema, y pese a los altos niveles de rendición que se están consiguiendo en esta anualidad, los cuales nos demuestran cómo han respondido las ELM ante el hecho de que si las administraciones que tienen atribuidas las competencias de control y fiscalización externa hayan exigido consecuencias proporcionales al incumplimiento o incluso gravosas como puede ser la amenaza de disolución, la solución o la situación podría mejorarse, a mi entender, siguiendo estas pautas:

$\checkmark$ Regulación normativa de un régimen más sencillo y flexible de exigencia de la gestión presupuestaria y contable hacia estas entidades (a nivel estatal), acompañada de un régimen jurídico propio esté regulado a nivel autonómico de simplificación y racionalización en cuanto a la organización y funcionamiento de las mismas, así como una simplificación y por qué no, una eliminación de las obligaciones de remisión derivadas de la Ley Orgánica de Estabilidad Presupuestaria hacia las entidades menores: eliminación para ellas de la necesidad de comunicación de los informes trimestrales de ejecución, regla de gasto y estabilidad, eliminación de las informaciones trimestrales del periodo medio de pago etc...

$\checkmark$ Regulación normativa de las funciones reservadas de intervención y llevanza de la fiscalización y contabilidad.

$\checkmark$ Es necesario y fundamental simplificar la gestión contable en estas ELM, de menor capacidad y con muy pocas competencias asignadas. La extensión de ese criterio de flexibilidad a otros aspectos adjetivos relacionados con la administración de las ELM, abogando por la simplificación de su actividad administrativa, de suerte que la misma se acompase al nivel de competencias que tengan atribuidas.

Facilitar la rendición de cuentas de manera más sencilla, estableciendo alguna consecuencia ante la falta de la misma. Se puede establecer, como ya se ha hecho en alguna convocatoria de subvenciones, que se exija en las mismas como requisitos a cumplir por las ELM, tanto la presentación de la rendición de cuentas como la 
remisión del resto de la información que se solicite por el órgano de tutela financiera, sería adecuado que tal medida la permitiera exigir una norma con rango legal para poder plasmarlo luego en las convocatorias y/o bases reguladoras de subvenciones que se aprueben y cuyos destinatarios o posibles beneficiarios sean las ELM.

$\checkmark$ Establecer la físcalización de un ente externo con un cuerpo jerarquizado con criterios comunes.

$\checkmark$ Exigir responsabilidades en aquellos supuestos, por ejemplo, de reconocimientos extrajudiciales de crédito desorbitados (ya que los mismos consisten en haber gastado en el ejercicio anterior sin crédito), pues resulta extraño que esta práctica a veces peligrosa no tenga cobertura de rango legal sino reglamentario a través del Real Decreto 500/1990, y que tengan efectos los informes de control para acabar con la sensación de impunidad de que nunca pasa nada.

No puede olvidarse el interés del Estado, o casi tendríamos que hablar de la responsabilidad del mismo, en el control financiero de las EELL. Ni que la organización de las EELL tiene que venir instituida mediante un sistema dirigido a evitar que funciones o competencias deban ser abandonadas por carencia de medios personales o materiales con los que hacer frente. El Tribunal de Cuentas recomienda en estos casos de disfunciones acudir a las administraciones asistenciales, es decir, a las Diputaciones Provinciales, cuando las entidades de menor tamaño perciban la inexistencia de capacidad con la que hacer frente a alguna de esas funciones, en especial las que se encuentran encomendadas a un determinado Cuerpo de Funcionarios como hemos visto. Por ello tal vez debiera repensarse la capacidad de las propias instituciones provinciales para poder prestar o incrementar la asistencia técnica que tienen encomendada y sobre todo los medios que a ella se destinan para dar cumplimiento a todas estas necesidades, pues si bien es verdad, es conocido que estas instituciones emplean recursos en la gestión de competencias "impropias", y no se debe olvidar la esencia misma de la función asistencial de estas instituciones que impone una obligación de colaboración dirigida a evitar el abandono o dejación de funciones por falta de medios. 
Desde un punto de vista teórico, y para intentar responder a la cuestión de la pervivencia de estas entidades, la misma se puede plantear a través de diversas soluciones organizativas:

- Solución continuista: esta solución pasa por el mantenimiento de las ELM existentes hasta el momento, viendo en ellas la consumación de la estructura municipal, pues no son pocos los autores que advierten en su seno la esencialidad del buen servicio de la Administración Pública. Una existencia de colaboración con los municipios, a la par que sirva para descargarles de alguna de sus funciones. Si bien nos encontramos con el límite de que, en la actualidad, ya no es posible constituir nuevas ELM, y sí organizaciones desconcentradas, y siempre ya con carácter voluntario y nunca impuesto. Es lo que se ha llamado un procedimiento estabilizador mediante el que se detiene la proliferación inframunicipal, cerrando el paso a la iniciativa de creación de nuevas ELM. Y quizás y, si fuera necesario, recoger la situación de ¿se podría regular una excepción a la creación de una ELM siempre que exista la previa disolución de otra?.

- Solución extintiva: la misma se puede plasmar en tres opciones:

- La ecléctica: se suprimen aquellas que carecen de condiciones indispensables para el cumplimiento de sus fines; insuficiencia demográfica, insuficiencia material, fundamentalmente la falta de patrimonio; motivos de necesidad económica y administrativa.

- La restrictiva: disminuir el número de ELM fundados los supuestos de disolución en razones ajenas a la capacidad misma de la entidad;

- $\quad$ La radical: se suprimen todas sin más, pasando a ser barrios, distritos, órganos desconcentrados.

- Solución armonizadora: en este supuesto se apuesta por una mayor implicación de las ELM en la gestión de la vida del municipio, que se traduzca en que aquellas no se preocupen únicamente, como hasta ahora de sus propios intereses privativos. A tal fin podríamos señalar las siguientes opciones: 
- $\quad$ Asunción centralizadora por parte del municipio de la representación política de la ELM, de todos los núcleos, posean o no bienes comunales. En el supuesto de que carecieran de bienes, nos hallaríamos ante la falta de justificación máxima de su existencia (la gestión de su propio patrimonio), lo cual nos llevaría a que la solución pasaría por disolver dicha ELM y transformarla en barriada del municipio, proponiendo un Alcalde de Barrio, delegado del Alcalde municipal. Si, por el contrario, poseyera la entidad bienes pero de escaso rendimiento económico, se podría proceder como en el caso anterior. Y si poseyera bienes de abundante rendimiento económico, habría que proveer su administración.

- Integración económica: el municipio asume directamente la administración de los bienes, entregando sus productos a las ELM y distribuyendo los aprovechamientos en cada localidad. Así la ELM conserva su personalidad jurídica, si bien esta opción puede ser fuente de no pocos conflictos y situaciones de desigualdad en el reparto de bienes que perteneciendo originalmente a un núcleo poblacional, finalmente redunden en beneficio del resto.

\section{VII.}

Que la reforma es necesaria y se debe acometer es indudable, pero la solución que se ha adoptado en los últimos cambios normativos vistos a lo largo de esta tesis no es, ni como mucho, la mejor opción, ya que, si bien es verdad que era necesario imponer a estas entidades un control más rígido a la hora de rendir sus cuentas y una previsión de intervención en las mismas, no es menos cierto que parece desproporcionado imponer a las Comunidades Autónomas la obligación de disolución de dichos entes locales por estas causas. Si bien y en mi opinión la aprobación de la LRSAL será una medida adecuada para poder poner en su debido lugar a cada una de las ELM, es decir, que se acredite la pervivencia de aquellas que verdaderamente tienen una madurez organizativa y económica suficiente, no menos cierto es que una vez suprimidas aquellas que incurran en causa de disolución, ya no existe previsión normativa de resurrección de las personificación de las mismas y no se permite a las CCAA la creación de nuevos entes infralocales. 
Que se crea con tal regulación una dualidad diferenciada de organizaciones (ya que pueden pervivir las que mantienen su personalidad jurídica y las que no), y esto traerá efectos jurídicos diferentes.

Que las ELM que tengan medios y capacidad, es decir, las que acrediten su grado de madurez y capacidad, deben existir, esa es nuestra postura, pero paralelamente deben adecuarse en cada municipio las fórmulas, quizás imperativas, que obliguen al funcionamiento eficaz de tales entidades, en una conexión racional de la actividad de las mismas y la de sus municipios.

Cuando los fines públicos que se persiguen, por causas de carácter general y económicas, llegan a constituir una carga superior a su potencialidad económica, es la Administración superior la que debe remediar tal situación, habilitando los medios legales y prácticos para simplificarlo, pero con una regulación que garantice la prestación de los servicios, y que se acredite el completo funcionando de las ELM, ya que aquellas que no cumplan no sólo con la obligación de rendición de sus cuentas si no en todo lo demás, serán absorbidas por los municipios, puesto que hoy en día no se puede mantener como criterio de validez la mera subsistencia política sin más, sino que debe venir acompañada de una eficiencia real. La idea de servicio público y la más eficaz realización de los fines comunes deben ser puntos de orientación en esta necesaria tarea de revisar y reajustar el concepto de entidad local menor y de adaptarlo al momento municipal presente. Se deberían respetar allí donde el impulso tradicional los mantiene y cuando su actividad separada realicen una verdadera función eficaz que contribuya a los fines que la justifican e impulsan la vida del municipio, pero siempre y cuando no se abuse de situaciones que por pura exaltación de antiguas formas locales no bastarían para sostener situaciones anacrónicas y que entorpecerían el desarrollo de los municipios mismos.

Para terminar y reproduciendo una cita de Florentino Agustín Diez:

"No es posible pues omitir en cualquier estudio que abarque con cierta conciencia ni en ninguna medida legal profunda que a la vida local afecte, para reconocerla, garantizarla o robustecerla, la existencia y la presencia de la comunidad de aldea, que cuenta con sus problemas, sus necesidades propias, con su vida y personalidad, y que como el humilde labrador que la habita, es un actor anónimo de la historia, como ha dicho un historiador ilustre; de la Historia, y del Derecho pudo, con razón, agregarse". 


\section{VII.- BIBLIOGRAFIA CONSULTADA}

AGIRREAZKUENAGA ZIGORRAGA, I. "La organización de las entidades locales" Iustel. http://www.iustel.com

ALCON ZARAGOZA, J.A. “Manual de elecciones locales”. Inap. Madrid. 1990.

ALMEIDA CERREDA, M. "La planta local a pequeña escala: municipios y entidades locales menores”. Revista Cuadernos de Derecho Local, no 35. Junio. Madrid. 2014.

ALONSO MAR, M.J. "Las entidades locales menores", en Comentarios a la LRBRL. Domingo Zeballos, MJ. (dir). Thomson Civitas. $2^{\text {a }}$ edición 2005 Navarra, pp. 834-875.

ANTELO MARTÍNEZ, A.R. "El ius in officium en la Sentencia 15/2013, de 6 de febrero del Tribunal Superior de justicia del Principado de Asturias". Iustel. http://www.iustel.com/diario_del_derecho_municipal/noticia.asp?ref_iustel=1112070

ARENILLA SAEZ, M. "Crisis y reforma de la Administración pública". Oleiros. Netbiblo. 2011.

ARNALDO ALCUBILLA, E. "El régimen electoral de las entidades locales menores" Revista de Derecho Administrativo, $N^{o} 103$ julio sept. 1999, pág. 383-399.

ARNALDO ALCUBILLA, E. / DELGADO IRIBARREN GARCÍA-CAMPERO, M. “Código Electoral” 6aedición. Madrid. La Ley. 2011.

BARCELONA LLOP, J. "Comentarios sistemáticos a la Ley 43/2003, de 21 de noviembre de Montes". Ed. Thomson Civitas. Navarra. 2005. 
BARRANCO VELA, R./RECUERDA GIRELA, M.A./FERNANDEZ DELPUECH, L. "Los símbolos representativos de las entidades locales: comentarios a la ley 6/2003, de 9 de octubre de símbolos, tratamientos y registro de entidades locales en Andalucía”. Instituto Andaluz de Administración Pública. Sevilla. 2006.

BAZ IZQUIERDO, F. "Explotación colectiva de los bienes comunales de aprovechamiento agrícola” Revista de Estudios Agrosociales, $n^{\circ} 51$. 1965. Pp. 33-68.

BELLO PAREDES, S. “Las entidades locales retos y perspectivas”. Jurisoft. Burgos. 2002.

- "La situación de las entidades locales en los estatutos de autonomía reformados: especial referencia al marco estatutario de Castilla y León”. Revista Jurídica de Castilla y León, $n^{\circ} 20$. Enero 2010.

BELLO PAREDES, S./MEDINA ARNAIZ, T. "Las relaciones de la comunidad autonómica de Castilla y León con el resto de entidades”. Derecho Público. Junta de Castilla y León. Lex Nova. Valladolid. 2008.

- “Castilla y León” Revista jurídica de Castilla y León. Monográfico $n^{\circ} 19$. Septiembre 2009. Valladolid.

BIOSCA LOPEZ, F.J. "La apariencia de control en la administración por los habilitados estatales" Revista Auditoría Pública, $n^{\circ}$ 52. Año 2010. Pp. 71-78.

BLANCO HIGUERA, A.L. "La propiedad pública de los montes como condición necesaria para su catalogación, antes y después de la Ley de Montes de 2003”. Revista Jurídica de Castilla y León $n^{o}$ 30. Valladolid. 2013.

- "La imprescriptibilidad de los bienes comunales: su trascendencia para la conservación de la propiedad forestal pública”. Revista Jurídica de Castilla y León, $\mathrm{n}^{\mathrm{o}}$ 32. Enero 2014. Valladolid. 
BLASCO DIAZ, J.L. “Descentralización, autonomía y entidades de ámbito territorial inferior al municipal". Revista de estudios locales y autonómicos, $n^{\circ}$ 312. 2010. Madrid. Pp. 47-79.

BOCANEGRA SIERRA, R. “Bienes comunales y vecinales”. Iustel. Madrid. 2008.

BODI MALLOL, J. “La entidad local menor”. Revista El funcionario municipal $n^{\circ} 221$. Pp. 63-64. Valencia. 1979.

BULLEJOS CALVO, C. “Comunidad política y autonomía local en Andalucía en el contexto del estado de las autonomías", El Consultor de los Ayuntamientos y juzgados, $n^{o}$ 18. 2012, pág. 2031.

CALVO SANCHEZ, L. (coord.) “Comentarios sistemáticos a la Ley 43/2003, de 21 de noviembre de Montes". Ed. Thomson-Civitas. Navarra. 2005.

CALONGE VELAZQUEZ, A. "Un exponente de la problemática actual entre Comunidades Autónomas y provincias: La gestión ordinaria de los servicios periféricos propios de la Comunidad Autónoma a través de las Diputaciones Provinciales". Revista de estudios locales y autonómicos, $n^{\circ} 232.1986$.

- “La planta municipal y las entidades locales menores en Castilla y León”. Revista de estudios locales y autonómicos, $n^{\circ}$ 285. Madrid. Pag. 135. 2001.

- “La organización territorial de Castilla y León”. En Derecho Público de Castilla y León (coord. SAEZ HIDALGO, I). Lex Nova. Valladolid. 2008.

CARRILLO DONAIRE, J.A./NAVARRO RODRIGUEZ, P. "La reforma del régimen jurídico de la Administración Local” Ed. La Ley. 2014.

CARPIO CARRO. M. "El informe CORA y la Administración Local”. El Consultor de los Ayuntamientos y juzgados, $n^{\circ} 14$. Madrid. 2013. Pp. 1395-1399. 
CASARES MARCOS, A.B. "Régimen local y prestación de servicios públicos en Castilla y León tras la aprobación de la Ley Autonómica 7/2013, de 27 de septiembre y la LRSAL” en QUINTANA LOPEZ, T./CASARES MARCOS, AB. “La reforma del régimen local”. Tirant Lo Blanch. 2014. Valencia pp. 769-850.

CASTRO BERMEJO, C. "Marco jurídico de la parroquia rural en Galicia" Revista de estudios locales y autonómicos, $n^{\circ}$ 276. 1998. Pp.179-199.

CEBRIAN ABELLAN, M. "Las relaciones de los entes locales con otras entidades públicas". Bayer hnos. Barcelona. 2005.

CHUECA RODRIGUEZ, R. “Las elecciones locales de 2011 en Aragón” Anuario Aragonés del Gobierno Local 2011. Pp. 207-301. Zaragoza. 2012.

COBO OLVERA, T. "Las comisiones gestoras". Actualidad Administrativa $n^{\circ}$ 46. 1994. Pp. 685-703

- "Ley de Bases del régimen local. Comentarios, concordancias y jurisprudencia". Ed. Bosch. Barcelona, 2004.pp.357-365.

- “Tratado de Derecho Local”. Aranzadi. Thomson Reuters. 2010. 1ª ed. Pp. 822841.

COLOM PIAZUELO, E. “Algunas reflexiones en torno a los bienes comunales" Revista de estudios locales y autonómicos, $n^{\circ}$ 237. Madrid 1988. Pp. 863-880.

- “Los bienes comunales en la legislación de régimen local”. Tecnos. Madrid. 1994.

- “Los bienes comunales" en Derecho de los Bienes Públicos, Ed. Tirant Lo Blanch. Valencia 2009. 
COMPANY VAZQUEZ, A.M. "Las ordenación del territorio en la Comunidad de Castilla y León y su sistema de planeamiento territorial, en especial, las Directrices de Ordenación del Territorio y las Directrices de Ámbito Subregional”. Revista jurídica de Castilla y León, $n^{\circ}$ 27. Valladolid. 2012.

COOLS. M./VERBEEK L. "Democracia local y regional en España". The Congress of Local and Regional Authorities. Bruselas. Febrero. 2013.

CORRAL GARCIA, E. "Las comunidades y la comunidad de villa y tierra de Cuellar". Revista de estudios locales y autonómicos, no 193. 1977.

- "Las entidades locales menores. Sus orígenes, desarrollo y competencias” Revista El Consultor de los Ayuntamientos y Juzgados, no 19. 2003.

CORRIPIO RIVERO, M. "La parroquia" Congreso jurídico de Asturias. Academia Asturiana de Jurisprudencia. Oviedo. 1987. Pp. 321-328.

COSCULlUELA MONTANER, L. voz “junta vecinal” Nueva enciclopedia jurídica. Seix. Barcelona. 1978.

- "La Ley de reforma de las elecciones locales” Madrid, 1983.

- "La organización y funcionamiento del concejo abierto". Revista de estudios locales y autonómicos, $n^{\circ}$ 234. Madrid. 1987. pp.199-224.

COSCULLUELA MONTANER, L./MUÑOZ MACHADO, S. “Las elecciones locales”. Madrid. 1979.

DIAZ LEMA, J.M. "El anteproyecto de Ley de racionalización y sostenibilidad de la Administración local: ¿cambio de rumbo en la Administración local española?’. Anuario del Gobierno Local 2012. Mayo 2013. Madrid. Pp. 47. 
DIEZ GONZALEZ, F.A. "Laciana: memoria de su antiguo y patriarcal Concejo". IEAL. Madrid. 1946.

- "La comunidad de aldea (apuntes históricos)". Revista de estudios locales y autonómicos, $n^{\circ} 80$. Madrid. 1955. Pp. 185-214.

- "León, provincia de aldeas y comarcas" Revista de estudios locales y autonómicos, $n^{\circ} 80$. no 123. Madrid. 1962. Pp. 342-370.

- “La función cooperadora en la provincia de León”. Revista de estudios locales y autonómicos, $\mathrm{n}^{\circ}$ 129. Madrid. 1963. Pp. 387-411.

- “León: aldeas y comarcas”. León. 1974.

- “La comunidad de aldea”. Imprenta provincial. León. 1974.

- "Funcionamiento de los municipios y entidades de concejo abierto". Valladolid, 1987.

DOMINGO ZEBALLOS, J.M. "Notas de actualización sobre el régimen jurídico de los funcionarios con habilitación estatal”. Revista de estudios locales. Cosital, $n^{\circ} 155$. Pp. 22-48. Madrid. 2013.

ESCUIN PALOP, C. "El sistema electoral municipal", Revista de estudios locales y autonómicos, $n^{\circ}$ 303, 2007. Pp. 93-126.

ESTEVE PARDO, M.L. "El impacto del principio de estabilidad presupuestaria sobre los Gobiernos Locales”. Anuario Gobierno Local 2012. Mayo 2013. Madrid. Pp. 153-172.

FARIÑA JAMARDO, J. “La parroquia rural en Galicia” IEAL. Madrid. 1975.

- "La entidad local menor y su proyección en Galicia", en homenaje a Carlos Ruíz del Castillo (coord. Manuel Aragón Reyes). IEAL, pp. 127-192. Madrid, 1985.

- “Alcaldes pedáneos, mayordomos y jueces" Revista de estudios locales y autonómicos, $n^{\circ}$ 196. Madrid. Pág. 767 
FERRAN DILLA, J. /CABELLO RODRIGUEZ, ML. "La externalización del control económico financiero en el ámbito local a la luz de la reciente Informe de fiscalización del Tribunal de Cuentas" Revista Española de Control Externo, $n^{\circ} 33.2009$. Pp. 39 a 64.

FERNANDEZ DE GATTA SANCHEZ, D. "Los problemas de la estructura municipal de Castilla y León: instrumentos y soluciones de la nueva Ley de Régimen Local”, El Consultor de los ayuntamientos y juzgados $n^{\circ} 19.1999$, pp. 2248 y 2249.

- "El régimen jurídico de las Comunidades de Villa y Tierra: aspectos históricos y régimen vigente". Revista Jurídica de Castilla y León, $n^{\circ}$ 21. Valladolid. 2010. Pp. 249-320.

- "La estructura municipal de Castilla y León: incidencia de la legislación sobre régimen local, urbanismo y ordenación del territorio”. Revista de estudios de la administración local $n^{\circ}$ 291, en Homenaje al Prof. Sebastián Martín-Retortillo. 2003.

FERNANDEZ CRIADO, J. "Régimen actual y futuro de las entidades locales menores". Revista tierras de León. Diputación de León. Volumen 25. Nº0. Pp. 25-36. 1985.

FERNANDEZ-MIRANDA FERNANDEZ-MIRANDA, J. "La jurisprudencia del TC en relación con el conflicto en defensa de la autonomía local" Administración y justicia: un análisis jurisprudencial: liber amicorum Tomás Ramón Fernández (García de Enterría Martínez Carande, E./Alonso García, R. coord.) Vol. 1. Madrid. 2012. Pp. 177-202.

FERREIRA FERNANDEZ, A.J./ARIAS MARTINEZ, M.A. "El pacto local y la reorganización competencial de la estructura interna de las corporaciones locales". Revista de estudios locales y autonómicos, $n^{\circ}$ 282. Madrid. 2000. Pp. 159-194.

FONT, J. BLANCO, I. "Participación local. Más allá de la democracia asociativa" Revista de estudios locales y autonómicos, $n^{\circ} 290.2002$, pp. 175-190. 
FUERTES LOPEZ, M. “Comentarios al art. 43 a 47” en Comentarios al Estatuto de Autonomía de Castilla y León (SAEZ HIDALGO/FERNANDO REY coord.). Civitas. Junta de Castilla y León. Pamplona. 2011

GALLEGO ALCALA. J. D. "Criterios inspiradores de futuras propuestas para fortalecimiento de las diputaciones provinciales". Revista El Consultor de los ayuntamientos y juzgados, $n^{\circ}$ 3. Madrid. 2012. Pp. 325

GALLEGO Y BURIN, A. "La entidad local menor como órgano de la vida municipal". Revista de estudios locales y autonómicos, $n^{\circ}$ 80. Madrid. 1955. Pp. 230

- "Municipios grandes, medianos y pequeños: estudio especial de las entidades rurales”. IEAL. Madrid. 1955.

GARCIA ALVAREZ, B. "Monografía sobre los concejos de parroquias y feligresías de Asturias”. Historia de la Administración Local. Tesis. Madrid. 1954.

GARCIA ASENSIO, J.M. "Sistemas vecinales de ejecución de los aprovechamientos comunales en las comarcas meridionales de las Distercias (Soria y Burgos)", Revista Aragonesa de Administración Pública, $n^{\circ}$ 18, Zaragoza, Junio 2001.

GARCIA DE ENTERRIA, E./FERNANDEZ, TR. “Curso de Derecho Administrativo”, Vol. I, Civitas, Madrid 2000, pp.379.

GARCIA GARCIA, M.J. "La elección directa de alcalde en el régimen local: justificación, alcance y repercusiones". Revista española de Derecho constitucional, $n^{\circ} 91$ enero abril 2011 pág. 205-207

GARCIA GIL, F.J. "La función de secretaría en los ayuntamientos”. Ed. El Consultor Madrid. 2011.

GARRIDO FALLA, F. "Entidades Locales Menores". Revista española vida local $n^{o} 35$. Madrid. 1947. Pp. 688-700 
GIRADO CID, C. "Las entidades locales menores: antecedentes legislativos y regulación actual. Régimen murciano" Revista anales del derecho, $n^{\circ} 11$ 1991. Pp. 237.

GOMEZ BARAHONA, A. "El derecho consuetudinario en el Derecho Público de Castilla y León” Revista jurídica de Castilla y León, $n^{o}$ 23. Valladolid. 2011.

GOMEZ PELLON, E. "Los concejos abiertos parroquiales asturianos. El caso del oriente asturiano" Libro del I Congreso Jurídico de Asturias, Oviedo, 1987, pp. 457-472.

GRACIA HERRERO, F.J. "La racionalización de la estructura organizativa en los pequeños municipios tras la reforma local". El Consultor de los ayuntamientos y juzgados, $n^{\circ}$ 5. 2014. Pp. 529-545.

GREGORIO MARTINEZ, M. "Las entidades locales menores tras la LRSAL". El Consultor de los ayuntamientos y juzgados, $n^{\circ} 5$. 2014. Pp. 570.

GRIFO BENEDICTO, M.A. "Las entidades locales y las relaciones interadministrativas”. IUSTEL. Madrid. 2009.

GUGLIERI NAVARRO, A. "Notas para un reajuste-concepto de entidad local menor". Revista de estudios locales y autonómicos, $n^{\circ}$ 80. Madrid. 1955.

LAGO NUÑEZ, G. "La tercera reforma del Régimen Local en España”. El Consultor de los Ayuntamientos y de los Juzgados. $n^{\circ} 5$. 2014. Pp. 443-477.

- “¿Para qué se ha aprobado la ley de racionalización y sostenibilidad de la administración local?”. El Consultor de los Ayuntamientos y de los Juzgados, $n^{o}$ 9. 2014. Pp. 984-987.

LAZO VITORIA, X. "El estatuto de los funcionarios locales con habilitación estatal y algunas reflexiones en torno al control interno económico financiero en el ámbito local". Revista española de Derecho Administrativo, $n^{\circ}$ 141. 2009. Civitas. Madrid. Pp. 137 a 163. 
- "El control sobre los entes locales tras la LRSAL. Rasgos fundamentales". Anuario de Derecho Municipal 2013. Madrid, 2014. Pp. 71-92.

LISON TOLOSAR, C. "Límites simbólicos. Apuntes sobre la parroquia rural”. Revista española de opinión pública. Marzo 1969. Pp. 101-151.

LLISET BORRELL, F. "La competencia de las entidades locales menores" Revista española de derecho administrativo, $n^{\circ}$ 50, 1986, pp. 261.

LOPERENA ROTA, D. "El mapa municipal ante la reforma del régimen local de Navarra". Revista jurídica de Navarra, $n^{\circ}$ 5. 1988. Pp. 107-118

MACEDA RUBIO, A. "La ordenación histórica del espacio en la parroquia de Arenas de Cabrales (Asturias), a través de sus ordenanzas”, Ería, 75, 2008, págs. 27-51.

MARQUES CARBO, L. “El derecho local español”. Tomo I. Informaciones Municipales. Barcelona. 1957.

MARTINEZ DIAZ, A. "Régimen económico de las entidades locales menores". Revista de estudios locales y autonómicos, $n^{\circ} 80$. Madrid. 1955. Pp. 215

- voz "entidades locales menores" en Nueva enciclopedia jurídica. Seix. Barcelona. 1978.

MARTINEZ MANOVEL, A. / PEDREIRA GARCIA, J. "Las entidades locales menores: pasado, presente y futuro". Revista El Consultor de Ayuntamientos y Juzgados $n^{\circ} 21.2002$. Pp. 3497.

MARTINEZ MARIN, A. "La reforma 2003 de los funcionarios locales con habilitación estatal" Revista de estudios locales y autonómicos, $n^{\circ}$ 291.2003, pp. 678.

MELLADO RUIZ, L. "Notas críticas sobre el anteproyecto de la Ley de Racionalización y Sostenibilidad de la Administración Local: entre la reforma y la intervención". Revista CEMCI. N $N^{o}$ 17. Oct.-Dic. 2012. 
- "Consecuencias derivadas de la supresión del principio de mayor proximidad". $E l$ Consultor de los Ayuntamientos y juzgados, $n^{\circ} 5$. Marzo 2014. Pp. 508.

MENENDEZ GARCIA, P. "Las entidades locales de ámbito inferior al municipio, en Tratado de Derecho Municipal, dirigida por Santiago Muñoz Machado". Iustel. Madrid 2011

MERINO ESTRADA, V. "El régimen local y el concejo abierto en Castilla y León" Jornadas sobre el Concejo Abierto. Junta de Castilla y León. 1989. Valladolid.

MERINO ESTRADA, V (coord.), ORDUÑA REBOLLO, E. VVAA. "Secretarios, interventores y tesoreros de la Administración Local. Doscientos años al servicio de la ciudadanía”. COSITAL. Madrid. 2012.

MIRA-PERCEVAL PASTOR, A./CORTELL GINER, R. "La rendición de las cuentas de las entidades locales y sus entes dependientes". Revista Auditoría Pública, no 40. 2006. Pp. 87-92.

MORELL OCAÑA, L. "Las entidades locales elementos integrantes de la organización del Estado y de las comunidades autónomas". Revista española de derecho administrativo, $n^{\circ}$ 55. 1987. Pp. 325-352.

- "Las elecciones locales", en Libro homenaje a Carlos Ruiz del Castillo (coord. Manuel Aragón Reyes). 1985. Pp. 437-456.

- "La articulación de la Administración del Estado y las entidades locales" Revista estudios vida local, $n^{\circ} 172.1971$. Pp. 586 a 628.

- "Situación y perspectivas de los funcionarios de administración local con habilitación nacional". Justicia administrativa: revista de derecho administrativo, $n^{\circ} 1$ extra. 2000. Pp. 207-230. 
MORENO SERRANO, B. "Las 10 claves de la LRSAL". El Consultor Web. http://www.dival.es/oficina-de-informacion/sites/default/files/oficina-deinformacion/Las_10_claves.pdf

MORILLO VELARDE PEREZ, J.I. "Las Entidades Locales Menores”, en Diccionario de Derecho Administrativo. Jerez. IUSTEL. 2005. pp. 1104-1109.

NIETO, A. "Entes territoriales y no territoriales", Revista Administración Pública $n^{\circ}$ 64, 1071, pp.29-51.

- "La nueva regulación de los bienes comunales", Revista de estudios locales y autonómicos, $n^{\circ} 133,1987$.

NIETO GUERRERO, A. "Los entes locales municipales. Entre la política y la administración”. Ed. MAP-INAP. Madrid. 2001 pp. 190-192.

OFICIALDEGUI GANUZAS, C.M. “Los bienes comunales en La Rioja: radiografía de una realidad física perspectivas de futuro". La Rioja. 2005.

ORDUÑA REBOLLO, E. "La evolución del concejo abierto" Revista de estudios locales y autonómicos, $n^{\circ} 237.1988$.

- "Las entidades de ámbito territorial inferior al municipio. Del pasado al futuro", en El Derecho Administrativo S. XXI. Fco. Sosa Wagner (Coord). Homenaje al Dr. D. Ramón Martín Mateo. Tomo I. pp. 745-772. 2000.

- "Municipios y provincias. Historia de la Organización territorial española", FEMP-INAP, Madrid 2003.

- “De los pueblos y aldeas a las entidades locales menores". Revista Carta Local $n$ 150. FEMP. Madrid. 2003. Pp. 40-41 
- “Las entidades locales menores en nuestros días". Revista Carta Local $n^{\circ} 155$. FEMP. Madrid. 2004. Pp. 42-43

ORDUÑA REBOllo, E. / COSCULlUElA MONTANER, L. "Historia de la legislación de régimen local'. Iustel- Fundación Democracia y Gobierno Local. Madrid. 2008.

ORTEGA JIMENEZ, M.P. "La normativa autonómica para garantizar la prestación de ciertos servicios por parte de las entidades locales en Castilla y León”. El Consultor de los ayuntamientos y juzgados, $n^{\circ}$ 9. Madrid. 2014. Pp. 988-998.

QUINTANA LOPEZ, T. “Algunas cuestiones sobre la vertebración administrativa”. Revista Jurídica de Castilla y León, núm. Extraordinario, 2006, pp. 317 y ss.

- “Comentario al art. 43” en Comentarios al Estatuto de Autonomía de Castilla y León. Civitas. Junta de Castilla y León. Pamplona. 2011.

- “La reforma del régimen local”. Tirant Lo Blanch, Valencia. 2014.

PALADIN, L. "Competenze statali e competenze regionali in tema di enti territoriali menori” Revista Foro Administrativo, IL, 3. Pp. 275-286. Milán. 1972.

PALLARES, SERRANO, A. “Aproximación al régimen jurídico de las entidades de ámbito inferior al municipio en Cataluña”. Revista de estudios locales y autonómicos, $n^{o}$ 9. 2009. Pp. 135-156.

PAREJO ALFONSO, L. “Garantía institucional y autonomías locales”, IEAL, Madrid, 1981, pp. 146.

- “Algunas reflexiones sobre el impacto de la Ley 27/2013, de 27 de diciembre, sobre el modelo de autogobierno municipal". Cuadernos de Derecho Local $n^{\circ} 34$. Febrero 2014. Madrid. Pp. 11-20

- "La autonomía local desde el punto de vista de su realización efectiva". Revista electrónica CEMCI $n^{\circ}$ 18. Oct/Dic. 2008. 
PASTOR GARCIA, JM. "La indeterminación del régimen jurídico aplicable al contrato de enajenación por venta de los bienes municipales en Castilla y León”. El Consultor de los Ayuntamientos y juzgados, $n^{\circ} 1.2010$. Pp. 70 .

PEREZ PEREZ, M.M. "Las entidades Locales Autónomas en la Ley de Autonomía Local de Andalucía (LAULA)”, El Consultor de los Ayuntamientos y los Juzgados, nº 24. 2011, pág. 3490.

PIQUERAS ARENAS, J.A. "Bienes comunales: propiedad, arraigo y apropiación”. Serie Estudios. Ministerio de Agricultura. 2002.

PIZARRO NEVADO, R. “Artículo 45”, en Comentarios a la Ley Reguladora de las Bases de Régimen Local (dir. Manuel Rebollo Puig) tomo I, Tirant lo Blanch, Valencia. 2007.

- "Las entidades de ámbito territorial inferior al municipio" Centro de Estudios municipales y de cooperación Interprovincial, CEMCI, Granada, 2002.

POSADA, ADOLFO “Evolución legislativa del régimen local en España 1812-1909” IEAL. Madrid. 1982.

PONS BRUNET, M. "Las entidades locales menores. Consideraciones sobre sus existencia y régimen” Revista de estudios vida local, $n^{\circ} 46.1949$, pp. 553 y 554.

PUEYO MOY, J. "La incidencia en los Concejos Abiertos y Entidades Locales Menores de Aragón de la modificación del régimen de Concejo Abierto en la Ley 7/1985, operada por la Ley Orgánica 2/2011, de 28 de enero" Anuario Aragonés del Gobierno Local, 2010. pp. 363-380

RAZQUIN LIZARRAGA, J.A. "La competencia de los concejos navarros en materia de planeamiento urbanístico". Revista jurídica de Navarra, $n^{\circ} 1$. 1986. Pp. 35-56.

RAZQUIN LIZARRAGA, M.M. / ENERIZ OLAECHEA, F.J. "Derecho local de Navarra" Gobierno de Navarra. Instituto Navarro de Administraciones Públicas. Pamplona. 2005. 
REBOllO PUIG, M. “Artículo 4” en Comentario a la Ley Reguladora de las Bases de Régimen Local (dir. Manuel Rebollo Puig) tomo I, Tirant lo Blanch, Valencia. 2007.

- "La supresión de los pequeños municipios: régimen, alternativas, ventajas e inconvenientes" Revista de estudios locales y autonómicos, $n^{\circ}$ 308. Inap. Madrid. 2008. pp.151-205.

REBOLLO PUIG, M. / PIZARRO NEVADO, R. "Las entidades locales autónomas" Revista Andaluza de Administración Pública, $n^{\circ}$ 42, 2001. Pp. 64 y 65.

RIGAU CAIXES, J.M. "Regulación legal: doctrina jurisprudencial” Revista jurídica de Catalunya, 1. 1995. Pp. 51-73

RIVERO ORTEGA, R. "Alteraciones de la planta municipal y reinvención de las Diputaciones”. Revista de Estudios Locales CUNAL. 2014. № 169. Pp. 62-95.

RIVERO ORTEGA, R./ SANCHEZ SANCHEZ, Z. "Participación ciudadana en el ámbito local”. Tratado de Derecho Municipal de Santiago Muñoz Machado (Dir) Tomo II. Iustel. Madrid. 2011, 3º ed. Pág. 1419-1463.

RIVERO YSERN, E. "El Estatuto de Autonomía de Castilla y León después de la reforma" en BLANCO RODRIGUEZ. J.A. (Coord) "Regionalismo y autonomía en Castilla y León”. Junta de Castilla y León. Valladolid. 2004.

RIVERO YSERN, J.L. “Manual de Derecho Local”. Civitas. Madrid. 2003.

- "La provincia en la Ley de Racionalización y sostenibilidad local 27/2013”.http://laadministracionaldia.inap.es/noticia.asp?id=1503369\&nl=1\&utm _source=newsletter\&utm_medium=email. 9 de junio de 2014. Revista General de Derecho Administrativo 36 (Iustel - mayo 2014)

RODRIGUEZ CATIVIELA, V. "Las Entidades Locales Menores en Aragón: situación y perspectivas" Revista Aragonesa de Administración Pública, nº 5. Pp. 445-462. Zaragoza. 1994. 
RODRIGUEZ MORO, N. "Los bienes comunales de las Corporaciones Locales”, Ed. Abella, 1969.

- "Las entidades locales menores y la recuperación administrativa de sus bienes". Revista de estudios locales y autonómicos, $n^{\circ}$ 193. Madrid. 1977. Pp. 161

- "Los bienes comunales tienen como titular al respectivo municipio, sin que pueda atribuirse tal titularidad a una Junta Vecinal administrativa de las mismas que venía funcionando al efecto", Revista Estudios de la Vida Local, no 214. Pp. 247358. INAP, Abril-Junio, 1982.

ROSA MORENO, J. “Aproximación histórica a la articulación orgánica de los núcleos separados de población” Revista de estudios locales y autonómicos, $n^{\circ} 262$. Madrid. 1994.

RUIZ RODRIGUEZ, F. “El submunicipio español. La entidad local ante el derecho”. Casa Cimiano. Santander. 1960.

SACRISTAN Y MARTINEZ, A. “Municipalidades de Castilla y León”. IEAL. Madrid. 1981.

SALANOVA ALCALDE, R. "El Concejo abierto en Aragón. La Ley 9/2009, de 22 de diciembre reguladora de los concejos abiertos". Anuario Aragonés del Gobierno Local $n^{o} 1$. Zaragoza. 2010.

SALAZAR BENÍTEZ, O. “Constitución, estatutos de autonomía y gobierno local: claves para una lectura de la administración local y autonómica" Revista de estudios locales y autonómicos, $n^{\circ} 309,2009$, pp. 93-134.

SALVADOR CRESPO, M. "Las competencias de las diputaciones provinciales en la Ley 27/2013, de 27 de diciembre, de racionalización y sostenibilidad de la Administración Local”. Cuadernos de Derecho Local, n³4. Febrero 2014. Madrid. Pp. 126.

SANCHEZ GOYANES, E. "La potestad normativa del municipio español” Ed. El Consultor. 2.000 . 
SANCHEZ SANTIAGO, J.L. "El sistema del concejo abierto en las entidades de ámbito territorial inferior al municipal”. Junta de Castilla y León. Valladolid. 1987.

SANZ RUBIALEZ, I. "Refuerzo competencial". Revista Jurídica de Castilla y León número extraordinario Pacto Local 2003. Pp. 61.

SERRANO PASCUAL, A. "El empleo público en la Ley de racionalización y sostenibilidad de la administración local: claroscuros y falta de apuesta firme por la modernización y por un modelo funcionarial de lucha contra la corrupción”. El Consultor de los ayuntamientos y juzgados, $n^{\circ} 5$. 2014. Pp. 590-613.

SORIA SESE, L. "Derecho municipal Guipuzcoano". Oñati. 1992.

SOSA WAGNER, F. "La autonomía local” en Estudios sobre la Constitución Española en libro homenaje al profesor Eduardo García de Enterría (coord... por Sebastián Martín Retortillo Baquer), Vol 4. Ed. Civitas. 1991. pp. 3185-3226.

- "Manual de derecho Local”, Aranzadi, Navarra, 2000.

- "Nuevo desalojo del Estado: secretarios e interventores", El Mundo, 30 de abril, 2007.

- "Administración Local” Derecho Público de Castilla y León, Lex Nova, Valladolid. 2008.

SOSA WAGNER, F. /DE MIGUEL GARCIA “Las competencias de las Corporaciones Locales” IEAL, 1985, pp. 74 y ss.

SOSA WAGNER, F. / FUERTES LOPEZ, M. "Código de la administración local" Aranzadi. Navarra. 2001.

SUAREZ OJEDA, M. "Las entidades locales menores: ¿menores de edad democrática? en Liber Amicorum Tomás Ramón Fernández. (Coord. García de Enterría) VVAA. 2012. Pp.77-103. 
TAMAYO BORRERO, E. “Administración municipal colombiana”. 2a ed. Guadalupe. 1988.

TOLIVAR ALAS, L. "La descentralización municipal: las parroquias asturianas". Documentación Administrativa $n^{\circ} 228.1991$.

- "Las prestaciones personales" Academia Asturiana de Jurisprudencia. Oviedo. 1991.

- "El personal de la administración local y el nuevo marco regulador de la función pública". Revista de Administración local y autonómica, $n^{\circ} 308.2008$. Pp. 9-46.

- "Las entidades inframunicipales" en "La reforma del régimen local" Tirant Lo Blanch. 2014.

- "Parroquias rurales: ¿reformando Estatutos por vía de ley ordinaria? http://administracionpublica.com/parroquias-rurales/

- “¿Tan difícil resulta concordar", El Blog de espublico, http://administracionpublica.com, 21 de febrero de 2014.

TORRES CURDI, F. "Las entidades locales menores en el Derecho administrativo español”. IEAL. Madrid. 1985.

TORT I DONADA, J. “Les entitats municipals descentralizades a Catalunya”, Generalitat de Catalunya, pp. 48-49. Barcelona, 1993.

VALENZUELA GARCIA, F. “El municipio y la entidad local menor”. Granada, 1964.

VERA TORRECILLAS, R.J. "Fundamento, origen y evolución de los Cuerpos Nacionales. Del constitucionalismo gaditano a las leyes municipal y provincial de 1870". Revista El Consultor de Ayuntamientos, $n^{\circ}$ 5. Pp. 558. Madrid. 2012. 
- "Los funcionarios de habilitación estatal en el contexto de la reforma del gobierno local”. El Consultor de los ayuntamientos $n^{\circ}$ 3.2012. pp. 259.

VV.AA. "El Estatuto de Autonomía del Principado de Asturias. Estudio sistemático", Junta General del Principado de Asturias, 2003.

VV.AA. "Compilación del Derecho Consuetudinario Asturiano", Junta General del Principado de Asturias. 2007.

VVAA. "Memento Administración Local". Lefevbre. 2010.

ZAFRA VICTOR, M. "Sorprendente normativa autonómica para el desarrollo de la Ley 27/2013, de 27 de diciembre, de racionalización y sostenibilidad de la Administración Local".En:http://laadministracionaldia.inap.es/noticia.asp?id=1503475\&nl=1\&utm_sourc $\mathrm{e}=$ newsletter\&utm_medoum $=$ email. 
Sentencia 30 de septiembre de 1927

Sentencia 12 de febrero de 1959

Sentencia de 26 de mayo de 1961

Sentencia 26 de mayo de 1961

Sentencia de 3 de abril de 1970

Sentencia de 4 de octubre de 1960

Sentencia de 31 de mayo de 1954

Sentencia de 29 de mayo de 1958

Sentencia de 22 de noviembre de 1955

Sentencia de 2 de mayo de 1961

Sentencia de 15 de noviembre de 1962

Sentencia de 3 de diciembre de 1956

Sentencia de 27 de abril de 1963

Sentencia de 15 de octubre de 1963

Sentencia 19 de octubre de 1957

Sentencia 3 de diciembre de 1956

Sentencia 11 de mayo de 1968

Sentencia de 05 de febrero de 1970

Sentencia 3 de octubre de 1958

STS de 3 de diciembre de 1956

STS de 9 de enero de 1957

STS 19 de mayo de 1960

STS 30 de noviembre de 1964

STS de 17 de mayo de 1969

STC 77/1984, de 3 de junio

STC 179/1985

STC 21 de diciembre de 1989

STC 308/1994, de 21 de noviembre

STC 103/2013, 25 de abril

STSJ Andalucía de 22 de mayo de 2000, de 4 de febrero de 2002 y 15 de marzo de 2002

STSJ Andalucía 14 de abril de 2008 y 3 de mayo de 2010

STSJ Andalucía de 14 de abril de 2008

STSJ Aragón 30 de septiembre de 1998

STSJ Aragón 24 de mayo de 2004

STSJ Asturias 29 de junio de 2007

STSJ Cantabria 9 de abril de 1987

STSJ Cantabria 14 noviembre 2000, rec. 433/1999

STSJ Cataluña 26 de marzo de 2003

STSJ Cataluña 21 de febrero de 2003

STSJ Galicia de 24 de mayo de 2007 y de 29 de marzo de 2006

STSJ Murcia 11 de junio de 2003

STSJ Navarra 26 de enero de 2004

STSJ Navarra 6 de noviembre de 2007 
STSJ País Vasco 31 de mayo de 2002

STSJ País Vasco 14 de julio de 2005; 11 de mayo de 2007

STSJ País Vasco 11 de mayo de 2007

STSJ Castilla y León 23 de enero de 1996

STSJ Castilla y León 15 de diciembre de 1999

STSJ Castilla y León 21 de julio de 2000

STSJ Castilla y León 24 de octubre de 2000

STSJ Castilla y León 13 de octubre de 2000

STSJ Castilla y León de 31 de mayo de 2001

STSJ Castilla y León 18 de octubre de 2001

STSJ Castilla y León de 11 de julio de 2001

STSJ Castilla y León de 11 de noviembre de 2004

STSJ Castilla y León 21 de enero de 2005

STSJ Castilla y León 8 de marzo de 2005.

STSJ Castilla y León 18 de noviembre de 2005

STSJ Castilla y León 14 de febrero de 2006

STSJ Castilla y León de 22 de septiembre de 2006

STSJ Castilla y León de 29 de septiembre de 2006

STSJ Castilla y León (Valladolid) de 21 de Junio de 2007, rec. 1698/2001

STSJ Castilla y León 18 de mayo de 2007

STSJ Castilla y León de 14 de diciembre de 2007

STSJ Castilla y León de 22 de julio de 2008

STSJ Castilla y León 16 de enero de 2009

STSJ Castilla y León 2 de febrero de 2010

STSJ Castilla y León de 2 de febrero de 2010

STSJ Castilla y León 675/2010, de 16 de marzo

STSJ Castilla y León 11 de junio de 2010

STSJ Castilla y León 15 de marzo de 2011

STSJ Castilla y León 6 de mayo de 2011

STSJ Castilla y León 28 de enero de 2013

STS 13 de marzo de 1980

STS 18 de mayo de 1982

STS 27 de septiembre de 1985

STS 27 de enero de 1986

STS 31 de diciembre de 1986

STS 30 de abril de 1987

STS 10 de julio de 1989

STS 24 de enero de 1989

STS 10 de julio de 1989

STS 10 de julio de 1989

STS 10 de julio de 1989

STS 3 de mayo de 1989

STS 24 de enero de 1989

STS 04 de diciembre de 1990

STS 3 de octubre de 1991

STS 20 de mayo de 1992

STS 22 de junio de 1992

STS 24 de septiembre de 1993 
STS 28 de septiembre de 1994

STS 14 de noviembre de 1995

STS 25 de octubre de 1995

STS 14 de noviembre de 1995

STS 25 de octubre de 1995

STS 30 de enero de 1996

STS 16 de enero de 1998

STS 20 de abril de 1998

STS 18 de octubre de 1999

STS 18 de octubre de 1999

STS 14 de septiembre de 2001

STS 21 de septiembre de 2006

STS 24 de mayo de 2007

STS 21 de febrero de 2007

STS 21 de febrero de 2007

STS 4 de diciembre de 2007

STS 19 de mayo de 2008

STS 17 de febrero de 2012

STS 11 de junio de 2013 